\title{
LUIZ RASCOVSKI
}

\section{A ENTREGA VIGIADA COMO MEIO DE INVESTIGAÇÃO}

\author{
DISSERTAÇÃO DE MESTRADO
}

ORIENTADOR: PROF. DR. ANTONIO SCARANCE FERNANDES

FACULDADE DE DIREITO

UNIVERSIDADE DE SÃO PAULO

SÃO PAULO 


\section{LUIZ RASCOVSKI}

\section{A ENTREGA VIGIADA COMO MEIO DE INVESTIGAÇÃO}

Dissertação apresentada à Banca Examinadora da Faculdade de Direito da Universidade de São Paulo, como exigência parcial para a obtenção do título de Mestre em Direito Processual, sob a orientação do Professor Doutor Antonio Scarance Fernandes.

FACULDADE DE DIREITO

UNIVERSIDADE DE SÃO PAULO

SÃO PAULO

2011 
Banca Examinadora 
Aos meus dois anjos, Isabela e Guilherme, fontes de alegria e inspiração. À minha esposa Daniela, companheira dedicada, mulher amada, que possibilita, com paciência e amor, que eu alcance meus objetivos. 


\section{AGRADECIMENTOS}

Foram três anos de dedicação e privação. Na verdade, dedicação aos estudos, à pesquisa, que culminaram na privação do convívio junto à família e amigos. Passada a tormenta, olho para trás e não me arrependo. Aliás, vejo o passado com orgulho e sensação de vitória.

Nessa trajetória agradeço, primeiramente, ao professor Doutor Antonio Scarance Fernandes. Difícil encontrar homem de bem tão obstinado com os estudos e apaixonado pela vida acadêmica. Agradeço por ter me acolhido como orientando, tornando possível o sonho do mestrado. Levarei para sempre as conversas na sala de vosso escritório, cada conselho, opinião e crítica debatida durante a elaboração desse trabalho. Sua simplicidade em me fazer enxergar as coisas de um modo mais claro e humildade na transmissão de seus infinitos conhecimentos fez admirá-lo e respeitá-lo ainda mais.

Agradeço aos amigos do instituto Antonio Scarance Fernandes, centro de estudos avançados de processo penal, composto de operadores de direito do mais alto gabarito e que pude compartilhar várias ideais, muitas das quais inseridas nesse trabalho.

Agradeço aos professores do curso de pós graduação que engrandeceram

minha formação acadêmica e proporcionaram muitas das lições e dos ensinamentos aqui utilizados, em especial aos professores: Marcos Alexandre Coelho Zilli, José Raul Gavião de Almeida, Gustavo Henrique Righi Ivahy Badaró, Antonio Magalhães Gomes Filho, Maurício Zanoide de Moraes e Maria Thereza Rocha de Assis Moura.

Fecho minha lista com o que considero a base de tudo, minha família. Agradeço minha mãe, mulher de muita fibra, exemplo para os filhos, que por diversas vezes abriu mão de privilégios pessoais para beneficiar suas crias. Hoje, diante da ausência de meu pai, consegue, ainda, continuar nos transmitindo suas lições de vida. Por falar em meu pai, onde estiver, sei que teria grande orgulho de mais essa vitória. Apesar da seriedade, esse 
homem com coração de tamanho jamais visto, à exemplo de minha mãe, abriu mão da vida particular para educar seus filhos da forma mais digna possível. Homem indispensável na formação de meu caráter.

Minhas irmãs, Alessandra e Andréa, companheiras de infância, atualmente minhas grandes amigas, com quem posso sempre contar.

Aos meus filhos queridos, Isabela e Guilherme, deixo aqui mais do que meu agradecimento, um pedido de desculpas, prometendo recompensas futuras pelos dias que tive de me ausentar, deixando de vivenciar momentos imperdíveis em vossos crescimentos.

Agradeço à minha esposa Daniela, excelente mãe, perfeita filha, parceira dedicada, merecedora de meu maior respeito, carinho, amor e admiração. Sempre me apoiando nos momentos delicados de minha carreira. Assiste com entusiasmo meu crescimento, sempre elogiando e fazendo-me crer acertado qualquer caminho que decida seguir. 


\section{RESUMO}

O presente trabalho objetiva o estudo dos aspectos legais pertinentes à entrega vigiada, vista como meio de investigação. A escolha do tema surgiu da preocupação com o avanço do crime organizado, que ganhou contornos transnacionais, e a necessidade de adoção de novos métodos de investigação, capazes de refrear este tipo de criminalidade. Cada vez mais os Estados percebem que os meios ordinários de investigação tornaram-se obsoletos e ineficazes para fazer frente ao avanço das operações desenvolvidas pelas organizações criminosas, porquanto se utilizam de modernos artifícios para perpetrar suas práticas delitivas.

Tratar-se-á da entrega vigiada propriamente dita, técnica que permite que remessas ilícitas ou suspeitas circulem de forma monitorada, sob controle das autoridades competentes, conceituando-a e apresentando suas características e peculiaridades, bem como procurando delimitar sua natureza jurídica. Também será examinado o tratamento conferido à entrega vigiada na legislação alienígena. Ademais, como instrumento de cooperação internacional, a entrega vigiada tende a ser adotada paulatinamente entre os diversos países signatários das convenções internacionais nas quais previstas este meio investigativo.

Para completa análise do instituto, indispensável enfrentar a árdua tarefa de ponderação da entrega vigiada à luz da eficiência e garantismo. Pretende-se apontar as possíveis ofensas aos princípios constitucionais e processuais penais que o meio investigatório da entrega vigiada pode acarretar, especificando os requisitos acreditados como indispensáveis para a regulamentação da entrega vigiada, de modo a delimitar sua atuação e, por conseguinte, evitar o cometimento de odiosos abusos por parte dos envolvidos no emprego desta técnica de investigação.

Serão expostos aspectos positivos, falhas e críticas ao instituto em exame. Almeja-se, como contribuição desta dissertação, a apresentação de algumas sugestões para o escorreito e eficaz emprego da técnica da entrega vigiada, de modo a resguardar, obrigatoriamente, os direitos do investigado. 


\begin{abstract}
The present work aims the study of pertinent legal aspects of monitored delivery, as a means of investigation. The choice of the subject came from the concern of the organized crime increase, that reached international levels and the necessity of adoption of new methods of inquiry, enabling to reprimand this type of crime. The State has acknowledged that the usual inquiry has become obsolete and inefficient in face of the advance of the operations developed by the criminal organizations, which make use of advanced techniques to perpetrate illegal practices.
\end{abstract}

It concerns the monitored delivery, a technique that allows illicit or suspicious packages to circulate freely, under control of the competent authorities, appraising them and presenting their characteristics and peculiarities, as well as their legal nature. Also the treatment to the monitored delivery in the foreign legislation will be examined. Furthermore, as an instrument of international cooperation, the monitored delivery tends to be adopted gradually entering the diverse signatory countries of the international conventions foreseen in this institute.

For complete analysis of the institute, indispensable to face the arduous task of balance of the monitored delivery to efficiency and warranty. It is intended to point the possible offences of the constitutional principles of penal law that the inquiry of the monitored delivery can result in, specifying the requirements as indispensable with respect to the regulation of the monitored delivery, in order to delimit its performance and, therefore, to prevent hateful abuses involving the inquiry technique.

Positive aspects, imperfections and criticism to the institute in examination will be exposed. It is intended, as a contribution of this dissertation, the presentation of some suggestions for the proper and efficient job of the technique of the monitored delivery, in order to protect, obligatorily, the rights of the investigated. 


\section{SUMÁRIO}

INTRODUÇÃO.

\section{CAPÍTULO I}

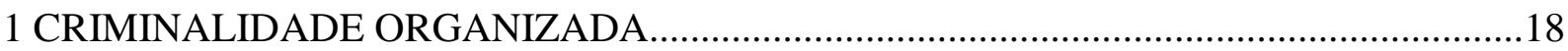

1.1 Origem, expansão e globalização do crime organizado.....................................................18

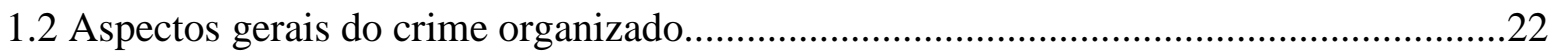

1.3 Política criminal de combate à criminalidade moderna.....................................................30

1.4 Meios de investigação e meios de formação da prova.

1.5 Necessidade de adoção de novos meios (técnicas) de investigação repressivos à

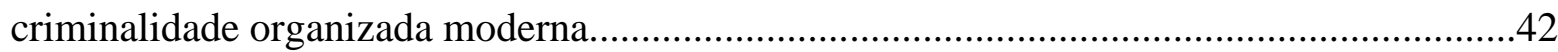

1.5.1 Ação controlada..............................................................................................4

1.5.2 Entrega vigiada X Ação controlada......................................................................52

\section{CAPÍTULO II}

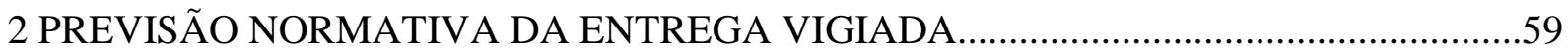

2.1 Origem e evolução normativa da entrega vigiada..............................................................59

2.1.1 Convênio de Schengen de 14/06/1985 ................................................................60

2.1.2 Convenção de Viena de 20/12/1988..................................................................63

2.1.3 Convenção Interamericana contra a fabricação e o tráfico ilícitos de armas de fogo, munições, explosivos e outros materiais correlatos - Washington de 14/11/1997 (CIFTA).

2.1.4 Convenção das Nações Unidas contra o crime organizado transnacional (Convenção de Palermo) de 15/11/2000 ........................................................................68

2.1.5 Convenção das Nações Unidas contra a corrupção de 31/10/2003 ........................70

2.1.6 Alguns pontos divergentes nas convenções..........................................................71

2.2 A entrega vigiada no Brasil: há previsão legal?..................................................................73 


\section{CAPÍTULO III}

\section{ENTREGA VIGIADA: CONCEITO, CARACTERÍSTICAS E}

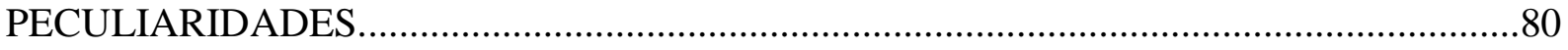

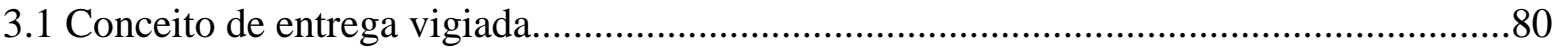

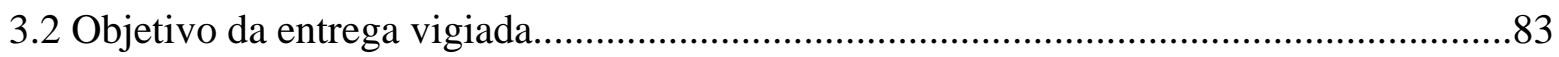

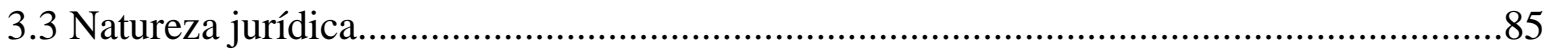

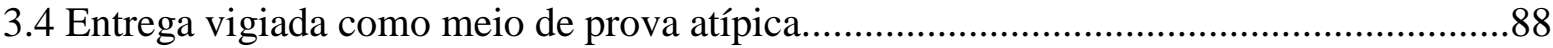

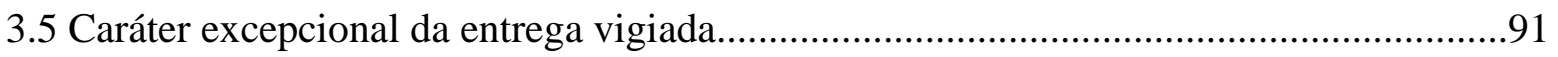

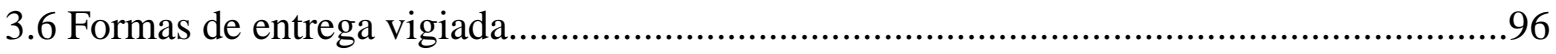

3.6.1 Interdição......................................................................................................97

3.6.2 Substituição.................................................................................................98

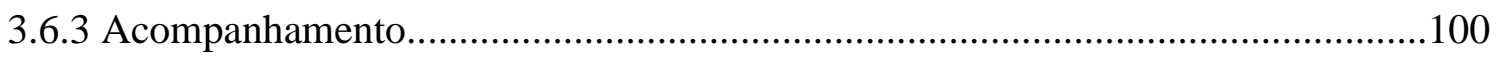

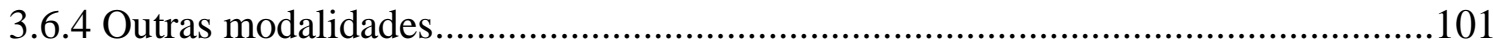

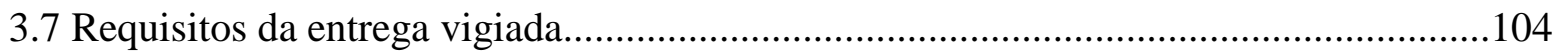

3.8 Interdependência da entrega vigiada com o agente infiltrado ou com outros meios de obtenção de prova para a efetiva consecução dos objetivos da entrega vigiada.

\section{CAPÍTULO IV}

4 ENTREGA VIGIADA NA LEGISLAÇÃO ESTRANGEIRA.............................................110

4.1 Análise do instituto no sistema legal estrangeiro..........................................................110

4.1.1 Espanha.......................................................................................................112

4.1.2 Argentina...............................................................................................118

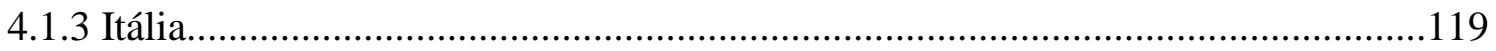

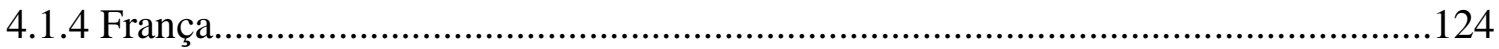

4.1.5 Alemanha.....................................................................................................127

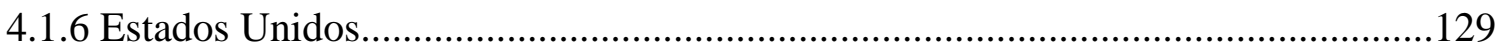

4.2. Alguns pontos comparados entre os países...............................................................131 


\section{CAPÍTULO V}

\section{PRINCÍPIOS CONSTITUCIONAIS E PROCESSUAIS PENAIS ENVOLVIDOS NA UTILIZAÇÃO DA ENTREGA VIGIADA.EFICIÊNCIA E GARANTISMO..

5.1 Considerações gerais acerca da eficiência e garantismo na persecução criminal. 133

5.2 A inviolabilidade do sigilo das comunicações e da intimidade no emprego da entrega vigiada. 138

5.3 Liberdade probatória e seus limites relacionados aos meios de obtenção de prova atípicos como a entrega vigiada. Falta de regulamentação legal que dificulta a aplicação do instituto e possibilita a afronta a direitos fundamentais.

5.4 Possibilidade de aplicação das regras atinentes à entrega vigiada previstas nos tratados internacionais ratificados pelo Brasil sem existência de legislação interna.

\section{CAPÍTULO VI}

6 CRÍTICAS E SUGESTÕES NA UTILIZAÇÃO DA ENTREGA VIGIADA.... 159

6.1 Críticas na utilização da entrega vigiada.

6.1.1 Insuficiência legislativa.

6.1.2 $\mathrm{O}$ agente (policial) vigilante provocando ou cometendo delito..... 161

6.1.3 Desvirtuamento na aplicação da entrega vigiada como instituto permissivo da perpetuação da criminalidade organizada. 164

6.2 Sugestões na utilização da entrega vigiada.

6.2.1 Necessidade de observância de condições mínimas na aplicação da entrega vigiada. 168

6.2.1.1 Possibilidade de utilização somente em crimes graves. 169

6.2.1.2 Permissão para utilização preferencialmente na fase investigatória.

6.2.1.3 Existência de acordos internacionais que permitam a vigilância entre diversos países (respeitados os princípios fundamentais dos respectivos ordenamentos jurídicos internos).

6.2.1.4 Necessidade de autorização da autoridade competente. .174 
6.2.1.5 Imprescindibilidade de motivação da decisão que autoriza a entrega

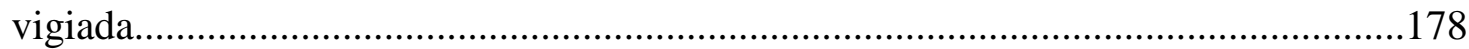

6.2.1.6 Autorização individualizada (caso a caso)/Análise do caso

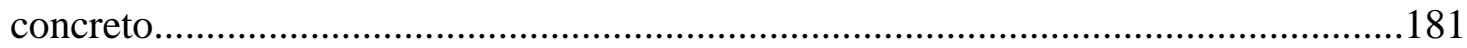

6.2.1.7 Observância da proporcionalidade da medida..........................................184

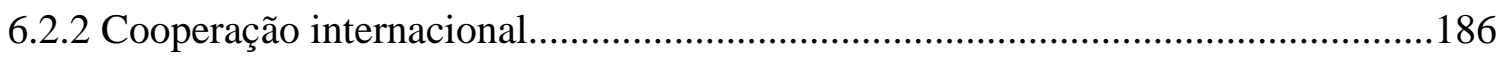

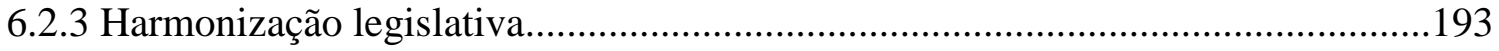

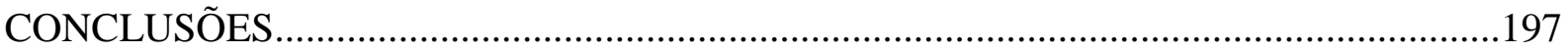

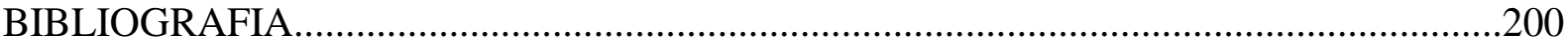




\section{INTRODUÇÃO}

A expansão da criminalidade organizada é uma realidade. Atualmente, no cenário mundial, um dos temas mais debatidos na seara jurídico-penal consiste justamente no avanço desta criminalidade, seus efeitos e os meios de combatê-la. Dificilmente, dentre os países de cultura avançada, deixa de se verificar uma fervorosa discussão, notadamente no âmbito doutrinário, da influência do crime organizado e a preocupação em conter seu crescimento.

Tal constatação se faz perceber porque a evolução natural da humanidade, decorrente da própria globalização pela qual atravessa a sociedade em pleno século XXI, derrubando fronteiras e acelerando a utilização de equipamentos tecnológicos de toda natureza, dos meios de transporte e de processamento de dados e da facilidade de circulação de pessoas, bens e ideias, trouxe também a reboque o irrefreável aprimoramento da criminalidade, em especial, da criminalidade organizada.

No cenário descrito, existe a discussão, ainda pendente de solução, relacionada à busca de um conceito definitivo de criminalidade organizada. Questiona-se a adoção de um conceito capaz de englobar todos os elementos caracterizadores dessa espécie de criminalidade, que para muitos auxiliaria, sobremaneira, na questão jurídica, trazendo o correto enquadramento e respectiva punição, ante o respeito ao princípio da legalidade. Para outros, consoante será apresentado, o conceito deve manter-se fluido.

A despeito dessa questão, certo é que a criminalidade organizada se revela como uma ameaça para a estabilidade e segurança das sociedades, ao enfraquecer as instituições e os valores da democracia, da ética, da justiça e ao comprometer o desenvolvimento sustentável do Estado Democrático de Direito.

A consciência da gravidade da ameaça que o crime organizado representa às sociedades contemporâneas e a percepção de que um problema que é, por sua natureza, 
transnacional, cada vez mais tem exigido dos Poderes Públicos uma réplica quanto à intranquilidade que causa no seio da sociedade.

Por isso, com o crescimento e desenvolvimento da criminalidade organizada, principalmente relacionada ao tráfico de entorpecentes, que se utiliza de meios extremamente modernos para atingir as suas finalidades, surgiu uma preocupação, inicialmente de âmbito nacional e agora mundial, em criar novos meios de investigação, algumas vezes excepcionais. Referidos meios objetivam auxiliar o Estado na busca de provas dos crimes praticados por essas organizações, tornando mais eficaz a persecução criminal.

Houve uma evolução paulatina da sociedade nas últimas décadas, sem a correspondente adequação da legislação criminal, que se vê diante da emergencial necessidade de adaptação de suas normas para acompanhar os crimes de seu tempo. Somente os métodos de investigação previstos no Código de Processo Penal, datado de 1942, já não são mais suficientes para enfrentar a criminalidade profissionalizada, ocasionando o engessamento da atividade estatal persecutória. E não se trata de uma dificuldade local, uma vez que tal deficiência tem se evidenciado em grande parte dos Estados ao redor do mundo, cujas legislações não mais acompanham o incremento do crime organizado.

Meios ordinários de investigação tornaram-se obsoletos e ineficazes para fazer frente ao avanço das operações desenvolvidas pelas organizações criminosas. É uma luta inglória perseguir as novas formas do crime organizado utilizando-se dos mesmos métodos empregados no enfrentamento à deliquência tradicional, perpetrada isoladamente, sem estrutura organizada e que não dispõem de avançados instrumentos tecnológicos. Fato é que o Estado não tem conseguido atingir seu objetivo de combater, de maneira eficaz, as atividades ilícitas das organizações criminosas valendo tão somente dos meios de investigação já existentes.

Essa nova realidade criminológica vem obrigando e desafiando o legislador, por vezes estagnado e inerte, a expedir novas normas, adequadas ao seu tempo, ao desenvolvimento de novas estruturas sociais e, consequentemente, à mais atual e requintada 
criminalidade organizada. Discutem-se, com isso, novas técnicas de investigação, capazes de comprovar a atuação das organizações criminosas. E justamente nesta busca frenética de adoção de novos meios de investigação surgiu a figura da entrega vigiada.

Trata-se, em síntese, de uma técnica ou um meio de investigação que consiste em permitir que remessas ilícitas ou suspeitas (sejam de drogas, substâncias entorpecentes, armas ou outros objetos ilícitos da atividade criminosa) circulem no interior de um Estado ou saiam do território de mais de um Estado, os atravessem ou neles entrem, de forma monitorada, com o conhecimento e sob o controle das autoridades competentes, para melhor atingir o objetivo de identificação de outros agentes participantes envolvidos na sua prática, bem como desvendar seu modus operandi.

De se frisar, inicialmente, que o presente trabalho adota as expressões: 'técnica', 'meio' ou 'método', como conceitos sinônimos, para que não possa causar aparente confusão terminológica, com a utilização de expressões diversas, mas que, ao menos neste trabalho, têm a intenção de representar a mesma coisa. Isto porque, nas convenções internacionais a entrega vigiada se encontra conceituada nominalmente como uma técnica (de investigação). Na legislação de alguns países e suas respectivas doutrinas, a entrega vigiada ora vem tratada como técnica (de investigação) ora como meio (de investigação). O Brasil tem o costume de adotar o conceito de meio de investigação, o que seria mais ajustado aos termos locais. Por fim, o termo método também será empregado algumas vezes, porque técnica, nada mais significa que um conjunto de métodos. Diante desse tratamento similar e para justificar eventual imprecisão terminológica, a entrega vigiada será mencionada como um meio, técnica ou método, todos de forma similar.

Agora, se por um lado, tem-se admitido a instituição de novos meios investigatórios por parte dos Poderes Públicos, consubstanciados em mecanismos necessários ao enfrentamento do crime organizado e que militam em favor de uma efetiva segurança, por outro lado, faz-se imprescindível não se admitir que referidos meios de investigação venham a ofender as garantias legais e constitucionais. 
A busca pela eficiência na persecução penal não pode se sobrepor às garantias individuais dos investigados. Há uma tensão de forças que desperta considerável conflito no aspecto processual penal, qual seja, alcançar o equilíbrio entre a eficiência na persecução criminal e o garantismo, no sentido de se preservar todas as regras protetivas dos direitos fundamentais do perseguido. Sem este equilíbrio não haverá o combate justo ao crime organizado.

No Brasil, o instituto da entrega vigiada ainda é muito incipiente. Alguns países (em especial a Espanha, por meio de sua 'Ley de Enjuiciamiento Criminal') já se encontram mais avançados em termos legislativos, inclusive com a delimitação da aplicação deste instituto, na tentativa de evitar que falhas e lacunas normativas propiciem o cometimento de abusos e desrespeito às garantias individuais.

No panorama traçado, o escopo do presente trabalho consiste em apresentar referida técnica de investigação, demonstrando que a entrega vigiada pode ser muito útil na luta contra a criminalidade organizada, bem como confrontar a utilização do instituto com a necessária preservação das garantias constitucionais e processuais penais.

A metodologia adotada consiste em traçar, inicialmente, um painel sobre a criminalidade organizada, delineando um paralelo dessa criminalidade com a iminente necessidade de adoção de novos meios de investigação, às vezes excepcionais, para combatêla.

Em seguida, apontar-se-á o surgimento da entrega vigiada, demonstrando que esse meio investigatório nasceu no seio de um Convênio entre Alemanha, Bélgica, França, Luxemburgo e os Países Baixos. A partir daí começou a se alastrar alcançando outros países, por meio de sua inserção em diversas convenções internacionais, para só então passar a ser regulamentada internamente em alguns destes países signatários. A técnica da entrega vigiada ainda aguarda detalhamento legislativo na maior parte dos países membros, signatários dessas Convenções. 
Passo seguinte, tratar-se-á da entrega vigiada propriamente dita, conceituando-a e apresentando suas características e peculiaridades, bem como procurando delimitar sua natureza jurídica. Também será examinado o tratamento conferido à entrega vigiada na legislação alienígena.

Apresentado e analisado o objeto do presente estudo, seguirá a árdua tarefa de ponderação da entrega vigiada à luz da eficiência e do garantismo. Pretende-se, nesse momento, apontar as possíveis ofensas aos princípios constitucionais e processuais penais que o meio investigatório da entrega vigiada pode acarretar.

Serão especificados os requisitos acreditados como indispensáveis para a regulamentação da entrega vigiada, de modo a delimitar sua atuação e, por conseguinte, evitar o cometimento de odiosos abusos por parte dos envolvidos no emprego desta técnica de investigação.

Ao final, serão apresentados aspectos positivos, falhas e críticas ao instituto em exame. Nossa contribuição derradeira vem justamente no tópico final deste capítulo, com a apresentação de algumas sugestões para o escorreito e eficaz emprego da técnica da entrega vigiada.

Em que pesem as dificuldades com as quais o Estado continuará se deparando para alcançar todos os integrantes das organizações criminosas, eventual legislação federal poderá assegurar um meio de investigação eficaz de combate ao crime organizado, por meio da entrega vigiada. 


\section{CAPÍtUlO I \\ CRIMINALIDADE ORGANIZADA}

\subsection{Origem, expansão e globalização do crime organizado}

A organização de grupos para a prática de crime não é um fenômeno da atualidade ${ }^{1}$. No entanto, consoante observado por Eduardo Araujo da Silva "a origem da criminalidade organizada não é de fácil identificação, em razão das variações de comportamentos em diversos países, as quais persistem até os dias atuais. Não obstante esta dificuldade, a raiz histórica é traço comum de algumas organizações, em especial as Máfias Italianas $^{3}$, a Yakuza Japonesa e as Tríades chinesas".

Apontam-se as tríades como a primeira manifestação de crime organizado, cuja atuação inicial teria ocorrido no ano de 1644, mas que somente a partir de 1842 teria agido mais fortemente. A Yakuza é do século XVIII e a Máfia surgiu em 1812. A Máfia Italiana alastrou-se para os Estados Unidos, no século XX. Na atualidade, causa grande preocupação o incremento de atividades terroristas, como motivação ideológica, e o surgimento ou desenvolvimento de organizações criminosas em diversos países ${ }^{4}$.

\footnotetext{
1 Tal constatação encontra-se exposta, com maior detalhamento, por Antonio Scarance Fernandes, in: $\mathrm{O}$ equilíbrio entre a eficiência e o garantismo e o crime organizado, In Repressão penal e o crime organizado. São Paulo: Editora Quartier Latin, 2009, p. 234.

${ }^{2}$ SILVA, Eduardo Araujo da. Crime Organizado. São Paulo: Editora Atlas, 2009, p. 3.

3 Sobre a origem e atuação das máfias italiana, japonesa e chinesa recomenda-se a leitura da obra: "Criminalidade Organizada", de Angiolo Pellegrini em parceria com Paulo José da Costa Jr., Editora Atlas, $2^{\mathrm{a}}$ edição, 2008.

${ }^{4}$ Sobre o crime organizado e seus aspectos processuais em diversos países consultar: a) na Argentina: “ $O$ crime organizado e o terrorismo na Argentina - Instrumentos e mecanismos legais de proteção", de Rodrigo Garcia Vilardi e Wagner Roby Gídaro; b) na Colômbia: "O crime organizado na Colômbia", de André Augusto Mendes Machado e Diego Fajardo Maranha Leão de Souza; c) na Espanha: "Crime organizado e Terrorismo na Espanha", de Marco Antônio Pinheiro Machado Cogan e Maria Jamile José; d) nos Estados Unidos: "Crime organizado e terrorismo nos Estados Unidos da América", de Fábio Ramazzini Bechara e Luís Fernando de Moraes Manzano; e) na França: "Crime Organizado e terrorismo na França”, de Elisa Pires da Cruz Reale Caçapava e Fernanda Regina Vilares; f) na Inglaterra: "O combate ao crime organizado e ao terrorismo na Inglaterra", de Fábio Franco Pereira e Ivo Anselmo John Junior) na Itália: "O crime organizado na Itália e as medidas adotadas para o seu combate", de Luiz Fernando Vaggione e Rodrigo Mansour Magalhães da Silveira; h) no Peru: "Crime organizado no Peru", de Fernanda Regina Vilares e Lia Verônica de Toledo Piza e i) em
} 
No Brasil $^{5}$, assinala-se como manifestação mais remota do crime organizado a atuação do cangaço, grupo dirigido por Virgulino Ferreira da Silva, conhecido por Lampião, e, depois, as organizações que se dedicavam à exploração do jogo do bicho, ao tráfico de entorpecentes, de armas, de animais silvestres ${ }^{6}$. Mais recente, cresceu e estruturouse o crime organizado nos presídios do Rio de Janeiro e de São Paulo ${ }^{7}$.

Contudo, independentemente das diversas origens das organizações criminosas $^{8}$ nos diferentes países, segundo Araujo ${ }^{9}$ alguns traços comuns podem ser destacados: "a maioria teve como nascedouro movimentos populares, o que facilitou sobremaneira sua aceitação na comunidade local, assim como o recrutamento de voluntários para o exercício de suas posteriores atividades ilícitas; muitas delas passaram a atuar no vácuo de algumas proibições estatais (como exploração da prostituição, jogos de azar, venda de entorpecentes e armas sofisticadas); contaram com a conivência de agentes do Estado para o desenvolvimento de suas atividades ilícitas; e impuseram sua lei pelo emprego de ameaça e violência, voltada, sobretudo, para delatores e integrantes de grupos concorrentes".

Mesmo com traços comuns, a criminalidade organizada floresceu e se manifestou em cada canto do mundo de forma isolada, aproveitando-se das mazelas locais

Portugal: "Crime Organizado em Portugal", de Luciana Russo e Silvio César Arouck Gemaque. Artigos da obra: "Crime Organizado - Aspectos Processuais" sob a coordenação de Antonio Scarance Fernandes, José Raul Gavião de Almeida e Maurício Zanoide de Moraes, Editora RT, 2010.

${ }^{5}$ A criminalidade organizada, que no Brasil tem seu berço nos presídios, de acordo com grande parte dos historiadores, profissionais de segurança pública, de comunicação e estudiosos do tema, tem avançado de forma significativa. Ver estudo aprofundado da criminalidade no Brasil em Dossiê Crime Organizado, Estudos Avançados da USP, plataforma Cielo, compilação de artigos sobre o crime organizado elaborado por juristas, sociólogos, filósofos, pesquisadores, dentre outros.

${ }^{6}$ Para Rodrigo Carneiro Gomes o crime organizado no Brasil não tem a conotação de uma organização mafiosa como descrita em filmes hollywoodianos, mas, sim, o comércio de drogas e armas em morros e favelas, facções criminosas dentro dos presídios, com estatuto próprio, compartimentação e hierarquia, a exemplo do Primeiro Comando da Capital (PCC), Comando Vermelho (CV), Amigos dos Amigos (ADA), Terceiro Comando (TC) e Terceiro Comando Puro (TCP). In: “O crime organizado na Visão da Convenção de Palermo", Belo Horizonte: editora Del Rey, 2009, p. 1.

${ }^{7}$ SILVA, Eduardo Araujo da. Crime Organizado. São Paulo: Editora Atlas, 2008, p. 25/26.

${ }^{8}$ Para Luiz Flávio Gomes e Raúl Cervini, a ação de gângsteres nos Estados Unidos foi um alerta de que tais grupos tinham suas raízes e diretrizes ainda fixadas no velho continente. Houve uma importação dos modelos criminosos para o novo mundo, uma internacionalização que teve início com a conexão Estados Unidos - Itália e é hoje refletida em diversos locais, com diferentes características. In: Crime Organizado: enfoques criminológico, jurídico (Lei 9.034/95) e político criminal. $2^{\mathrm{a}}$ edição. São Paulo: RT, 1997, p. 76.

${ }_{9}^{9}$ SILVA, Eduardo Araujo da. Crime Organizado. São Paulo: Editora Atlas, 2008, p. 27. 
para disseminar seus tentáculos. Porém, com o avanço da tecnologia aliada à globalização ${ }^{10}$, representada pela queda das fronteiras, notadamente nos países europeus e a facilidade de comunicação, o crime organizado ganhou novos contornos ${ }^{11}$, passando a se manifestar de forma concatenada e estruturada em diversos países, de maneira coligada ${ }^{12}$. É o caráter atual e transnacional do crime organizado ${ }^{13}$, que não mais respeita barreiras ${ }^{14}$.

Nicolás García Rivas ${ }^{15}$ reforça essa nova faceta do crime organizado, notadamente influenciada pela sociedade industrial, quando observa: "A criminalidade

${ }^{10}$ Walter Fanganiello Maierovitch faz uma comparação metafórica observando que o animal mais parecido com o
método pelo qual o crime organizado atua é a aranha, porque o crime organizado estende suas intrincadas teias
em diversos setores da sociedade, atuando com cautela, esperando que alguma vítima inocente, ou alguém que
inicialmente também queira alguma vantagem, caia nas armadilhas do caminho e seja vítima de suas presas, em
um ataque rápido, violento ou, por vezes, coberto de subterfúgios. (As associaçóes criminosas transnacionais. In: Jaques Camargo Penteado (Coord.). Justiça Penal: críticas e sugestões, v. 3. São Paulo: RT, 1995, p. 57).

${ }^{11}$ Mais do que nunca, a sombra do crime organizado está presente em todas as atividades do homem comum, mesmo quando ele parece uma realidade longínqua, apenas perceptível no noticiário da televisão. Longe vai o tempo em que o 'chefão' assumia ares de Al Capone, cercado de capangas e fumando longos charutos cuja fumaça escrevia no ar as palavras 'eu sou mau'. Ainda há gente assim, é claro, mas o mais provável é que os capos das máfias atuais estejam nos escritórios dos grandes bancos e corporações, em cargos importantes dos governos, nas instituições acima qualificadas, fora de qualquer suspeita. (Arbex Junior; Tognolli, 1996, p. 40/41). ${ }_{12}$ O Senador Romeu Tuma, discursando no Congresso, após retornar de uma sessão especial na Assembléia Geral da ONU dedicada ao problema mundial das drogas, em que acompanhou o Presidente da República do Brasil à ápoca, em 1998, já demonstrava sua preocupação com a expansão e globalização do crime organizado quando pronunciou: "Vivemos em um mundo que se tornou pequeno. As distâncias e os acidentes geográficos deixaram, no mais das vezes, de serem obstáculos para circulação de pessoas, bens e ideias. Não faltam elementos positivos nessas novas circunstâncias. Porém, é fundamental que a crescente permeabilidade das fronteiras não funcione como um incentivo à disseminação de atos criminosos nem facilite sua impunidade".

${ }^{13}$ Acerca do fenônemo da transnacionalidade do crime organizado é de se ressaltar a passagem da obra de Carlos Enrique Edwards, estudioso no assunto de crime organizado: "Otra característica que presenta narcocriminalidad es que se ha convertido en un fenómeno mundial; efectivamente, se trata de una actividad delictiva internacional, que ha trascendido las fronteras de cada país. Estas organizaciones de criminalidad vienen a funcionar como verdaderas 'transnacionales' del delito, lo cual implica un mayor grado de complejidad en la lucha contra esta forma de delincuencia, ya que en muchos casos se impone solicitar la extradición del imputado, con todas las complicaciones legales que ello produce". In: "El Arrepentido, El agente encubierto Y la Entrega Vigilada", Buenos Aires: Ad Hoc, 2001, p. 16.

${ }^{14}$ Para Jesús María Silva Sánchez: "La criminalidad organizada ha aumentado extraordinariamente sus actividades en los últimos años, afectando a toda la comunidad internacional y extendiéndose a muchos sectores de la actividad económica, favorecida tanto por la globalización (explosivo desarrollo de los medios de comunicación y transporte) como por la integración supranacional". (In: "La expansión del Derecho Penal. Aspectos de la política criminal en las sociedades postindustriales", Cuadernos Civitas, Paracuellos del Jarama (Madrid), 1999, p. 63). No mesmo sentido a ideia de Pino Arlacchi: "En definitiva, el motor de este fenómeno ha sido el crecimiento del mercado de productos ilegales, a nivel local y a nivel internacional, que se ha producido de forma paralela al progresivamente acelerado desarrollo de la economía internacional" (In: Tendencias de la criminalidad organizada y de los mercados ilegales en el mundo actual", Poder Judicial, $\mathrm{n}^{\circ}$ 16, p. 83.).

${ }^{15}$ RIVAS, Nicolás García. Criminalidad Organizada y tráfico de drogas. Revista Penal no 2 , Julio 1998, editorial Praxis en colaboración con las Universidades de Huelva, Salamanca Y Castilla - La Mancha, p. 23. Tradução livre do trecho original: "La criminalidad organizada es un fenómeno sociológico que se ha venido incrementando significativamente de manera paralela al proprio desarrollo de la sociedad postindustrial, que 
organizada é um fenômeno sociológico que vem se incrementando significativamente de maneira paralela ao próprio desenvolvimento da sociedade pós-industrial, que acarreta graves riscos para a vida social e para o próprio Estado de Direito, e cujo interesse dogmático se estende a lugares distintos do sistema penal".

A ampliação dos mercados ilícitos, a mobilidade dos bens que são seu objeto, com a consequente necessidade de seu transporte de um Estado para outro, a globalização dos mercados financeiros, indispensável para que os grupos criminosos alcancem sua exorbitante ganância econômica, a tecnologia utilizada neste e em outros setores estão incidindo, visivelmente, na estrutura da organização criminosa. Tais grupos do crime organizado têm assumido uma dimensão transnacional, cujo dado característico consiste no reconhecimento do fato que grupos criminais de diversas etnias ou nacionalidades colaboram entre si de forma eficaz, com a consequência de que cada estrutura particular obtém um valor agregado, em termos de potencialidade criminal, devido à sinergia que instaura com outros grupos.

Diante deste avanço, ressalta Vicente Greco Filho" ${ }^{16}$, que "no plano do criminoso ou da criminalidade, no passado, o direito penal focalizava o criminoso individual, a criminalidade em concurso e, no máximo, a quadrilha ou bando. $\mathrm{Na}$ atualidade a preocupação mundial é com a organização criminosa, com a criminalidade organizada ${ }^{17}$,"

genera graves riesgos para la vida social y para el proprio Estado de Derecho, y cuyo interés dogmático se extiende a distintos lugares del sistema penal".

${ }^{16}$ FILHO, Vicente Greco. A Entrega vigiada e o Tráfico de Pessoas, in Tráfico de Pessoas. São Paulo: Editora Quartier Latin, 2009, p. 290. (Ver também o texto A Entrega Vigiada e suas repercussões penais, do mesmo autor, disponível em <http://www.grecofilho.com.br/pdfs/entrega_vigiada.pdf>).

${ }^{17}$ Para chegar a este raciocínio o autor faz uma construção lógica da evolução dos crimes do individual para o coletivo, até alcançar a criminalidade organizada. Assim, para Greco: "o direito penal em épocas primitivas e até meados do século XXI tinha como preocupação a tutela dos bens jurídicos individuais. O furto, adotando como exemplo os crimes de conteúdo econômico ou patrimonial, era previsto desde o Código de Hamurabi; Roma antiga já previa o estelionato, com outra conformação, é certo, mas também protegendo o patrimônio individual. É possível identificar como uma das primeiras preocupações com direitos coletivos, ainda no campo econômicopatrimonial, os crimes falimentares e, entre nós, somente na segunda metade do século XX os crimes contra a economia popular. Da década de 1980 para cá a mudança de rumo foi radical: sem deixar de existirem os crimes de tutela do patrimônio individual a preocupação passou a ser da ordem econômica, financeira, daí a tipificação dos crimes contra o sistema financeiro, contra a ordem econômica, de proteção das relações de consumo etc. Também são a partir dessa época, os crimes contra o patrimônio ambiental e outros de proteção de interesses coletivos ou difusos, até os transnacionais, das organizações criminosas (FILHO, Vicente Greco. A Entrega vigiada e o Tráfico de Pessoas, in Tráfico de Pessoas. São Paulo: Editora Quartier Latin, 2009, p. 289/290). 
Tem sido diverso $o$ tratamento dado às diferentes formas de criminalidade, que, em termos conceituais e para fim de estudo, podem ser classificadas em três grupos: a criminalidade leve, a criminalidade comum $^{18}$ e a criminalidade grave ou organizada $^{19}$. Para esta última e justamente por sua gravidade, tem-se admitido um sistema especial $^{20}$, já que requer maior rigor em seu enfrentamento, mas sem descurar da observância das garantias individuais.

Neste trabalho, interessa justamente o especial tratamento dispensado à criminalidade organizada e a criação de novos meios de investigação - em especial a entrega vigiada - utilizados na persecução criminal desta classe de crimes tidos como graves, bem como sua análise em relação ao respeito das garantias individuais.

\subsection{Aspectos gerais do crime organizado}

A expansão do crime organizado vem adquirindo contornos inaceitáveis, sobretudo do ponto de vista do controle da delinquência. Resta, porém, em aberto uma questão tormentosa consubstanciada na dificuldade ${ }^{21}$ de se encontrar um conceito unívoco para o

\footnotetext{
${ }^{18}$ Reale Júnior faz este confronto entre as espécies de criminalidade, apontando: “Ao inverso das associações criminosas tradicionais, que vivem para a prática de delitos para depois buscar fontes de legitimação de seus rendimentos, os grandes conglomerados têm finalidade lícita ou aparentemente lícita, e transbordam para atividades ilícitas no afã de maiores lucros, sempre estimulados ou acobertados pelo poder econômico ou político que possuem. Não se submetem à necessidade de legitimar ganhos, porquanto, apesar de oriundos de atividades delituosas, vêm revestidos de aparente legalidade" (JÚNIOR, Miguel Reale. Crime Organizado e Crime econômico. Revista Brasileira de Ciências Criminais, São Paulo: RT, v. 4, nº 13, jan-mar, 1996, p. 186).

${ }^{19}$ Definição utilizada por Antonio Scarance Fernandes em "Processo Penal Constitucional", São Paulo, Editora RT, $3^{\text {a }}$ edição, 2002, p. 25. E também em Antonio Scarance Fernandes. O equilíbrio entre a eficiência e o garantismo e o crime organizado, In Repressão penal e o crime organizado. São Paulo: Editora Quartier Latin, 2009, p.227.

${ }^{20}$ Isto porque a criminalidade organizada certamente revela-se como uma ameaça para a estabilidade e segurança das sociedades, ao enfraquecer as instituições e os valores da democracia, da ética, da justiça e ao comprometer o desenvolvimento sustentável do Estado Democrático de Direito. Vale ressaltar que a Carta Magna de 88, em seu artigo $5^{\circ}$, XLIII, previu que a lei considerasse "crimes inafiançáveis e insuscetíveis de graça ou anistia a prática de tortura, o tráfico ilícito de entorpecentes e drogas afins, o terrorismo e os definidos como crimes hediondos".

${ }^{21}$ Para Antonio Scarance Fernandes: "Não é simples traduzir em uma regra jurídica tais características e definir a organização criminosa, mas, de alguma forma, é necessário que a lei fixe o que será considerado crime organizado ou organização criminosa, para, com base nessa norma, restringir direitos individuais". In FERNANDES, Antonio Scarance. $O$ equilíbrio entre a eficiência e o garantismo e o crime organizado, In Repressão penal e o crime organizado. São Paulo: Editora Quartier Latin, 2009, p.236.
} 
crime organizado ou para terminologia organização ${ }^{22}$ criminosa, notadamente porque a legislação pátria é omissa, deixando este trabalho para doutrina e jurisprudência. Contudo, tal dificuldade não é privilégio do Brasil.

\section{Há doutrinadores, dentre eles Vicente Greco Filho ${ }^{23}$ e o penalista} argentino Raúl Zaffaroni ${ }^{24}$, que entendem que há impossibilidade de conceituação de crime organizado e que as tentativas neste sentido foram frustradas ${ }^{25-26}$, pois constituem a pretensão (inalcançável) de prender em um conceito criminológico a dinâmica do mercado ${ }^{27}$.

É possível, no entanto, encontrar vários enfoques para conceituar organização criminosa ${ }^{28}$. Valendo-se da definição apresentada por Marcelo Batlouni ${ }^{22}$ Fernando Gascón Inchausti define organização como associação ou instituição com objetivos definidos (In
infiltración policial y "agente encubierto". Granada: Comares, 2001, p. 3).
${ }^{23}$ Sobre o assunto, Vicente Greco Filho observa: "Há quem afirme, que lei deveria, deve ou deverá estabelecer os
requisitos para que uma associação ou grupo se constitua em organização, mas não cremos que isso seja
adequado, uma vez que as organizações são muito diferenciadas e uma definição restringiria o conceito, tomando
impossível a identificação em face de exigências rígidas e expressas. O conceito deve manter-se fluido, como
fluido é o próprio modo de ser de uma "societas sceleris". Da doutrina, então, é que podem ser extraídas as
características básicas de uma organização criminosa que podem não estar presentes em todos os casos, mas
servem de base para o enquadramento jurídico da situação (FILHO, Vicente Greco. A entrega Vigiada e Tráfico
de Pessoas. In: Tráfico de Pessoas. Coord. Laerte Marzagão Junior. Ed. Quartier Latin do Brasil. São Paulo,
2010 , p. 292).

${ }^{24}$ ZAFFARONI, Raúl. Op. Cit. p. 67.

${ }^{25}$ Francis Rafael Beck ressalta que é consenso na doutrina a ideia de que, pelo menos até o presente momento, não é possível o estabelecimento de um conceito definitivo de crime organizado, podendo somente, e no máximo, aproximarmos seu conteúdo. In Perspectivas de controle ao crime organizado e crítica à flexibilização das garantias. IBCCRIM, p. 68.

${ }^{26}$ Neste diapasão Joaquín Delgado Martín, na obra La Criminalidad Organizada, reitera tal dificuldade: "Resulta harto complicada la confección de una definición de la delincuencia o criminalidad organizada, tanto por la heterogeneidad con la que se manifiesta, como por la multitud de sectores sociales y económicos a los que afecta" (J. M. Bosch - Editora, Barcelona, 2001, p. 35).

${ }^{27}$ Para Raúl Zaffaroni o crime organizado é um fenômeno de mercado desorganizado ou não disciplinado, que se abre à disciplina produzida pela atividade empresarial lícita ou menos lícita. Op. cit. p.46.

${ }^{28}$ Para Rodolfo Tigre Maia crime organizado é a forma de criminalidade consentânea com o estágio atual do desenvolvimento do modo capitalista de produção (inclusive do capitalismo de estado que vigorou na antiga URSS), marcado, sobretudo, pela hegemonia norte-americana no pós-guerra, pelo incremento do desemprego, pela interdependência das economias nacionais, pela contínua associação do capital bancário com o capital industrial, pela crescente concentração e internacionalização do capital, processo anteriormente designado por imperialismo, mas hoje, para esvaziar seu conteúdo ideológico, mais conhecido pelo epíteto neoliberal de "globalização da economia" (In $O$ Estado desorganizado contra o crime organizado, p. 21/22). Para Guaracy Mingardi, entende-se por organização criminosa "o grupo de pessoas voltadas para atividades ilícitas e clandestinas que possui uma hierarquia própria e capaz de planejamento empresarial, que compreende a divisão do trabalho e o planejamento de lucros. Suas atividades se baseiam no uso da violência e da intimidação, tendo como fonte de lucros a venda de mercadorias ou serviços ilícitos, no que é protegido por setores do Estado ${ }^{28}$. Tem como características de qualquer outro grupo criminoso um sistema de clientela, a imposição da lei do 
Mendroni $^{29}$ é "o organismo ou empresa, cujo objetivo seja a prática de crimes de qualquer natureza - ou seja, a sua existência sempre se justifica porque - e enquanto estiver voltada para a prática de atividades ilegais. É, portanto, empresa voltada à prática de crimes”.

As diversas linhas doutrinárias e legislativas, normalmente adotadas para a definição de crime organizado ${ }^{30}$, se utilizam de critérios diversos que podem ser condensados em três grandes grupos ou correntes: 1) o que parte da noção de organização criminosa para definir o crime organizado (o qual, assim, seria aquele praticado por membros da organização); 2) o que define o crime organizado, sem especificação de tipos penais, mas com base nos seus elementos essenciais, em regra, aqueles que servem para identificar a existência de uma organização criminosa e 3) o que especifica um rol de crimes (tipos penais) como sendo crimes organizados.

Desta forma, os seguidores da primeira corrente sustentam que o caminho ideal seria definir, em primeiro lugar, organização criminosa, porque, uma vez definido seu conceito, seria possível alcançar os responsáveis pela perpetração do crime organizado.

A segunda corrente, que procura conceituar organização criminosa por intermédio dos elementos caracterizadores que a compõem, é a que prevalece ${ }^{31}$.

silêncio aos membros ou pessoas próximas e o controle pela força de determinada porção de território" (MINGARDI, Guaracy. O Estado e o Crime Organizado. São Paulo: IBCCRIM, p. 82).

${ }^{29}$ MENDRONI, Marcelo Batlouni. Crime Organizado. Aspectos Gerais e Mecanismos Legais. $2^{\text {a }}$ Edição. São Paulo: Editora Atlas, 2007, p. 6.

${ }^{30}$ Dentre as diversas tentativas de se definir o que seja uma organização criminosa pode se destacar o conceito trazido por: 1) FBI - Federal Bureau of Investigation: "qualquer grupo tendo algum tipo de estrutura formalizada cujo objetivo primário é a obtenção de dinheiro através de atividades ilegais. Tais grupos mantêm suas posições através do uso de violência, corrupção, fraude ou extorsões, e geralmente têm significante impacto sobre locais e regiões do País onde atuam"; 2) Interpol: "qualquer grupo que tenha uma estrutura corporativa, cujo principal objetivo seja o ganho de dinheiro através de atividades ilegais, sempre subsistindo pela imposição do temor e a prática da corrupção"; 3) ONU: "organização de grupos visando à prática de atividades econômicas; laços hierárquicos ou relação e pessoais que permitem que certos indivíduos dirijam o grupo; o recurso à violência, à intimidação e à corrupção; e à lavagem de lucros ilícitos" (Conferência da ONU em novembro de 1994); 4) EU União Europeia: "associação estruturada de mais de duas pessoas estabelecidas durante um período de tempo e que atue de maneira concertada com o fim de cometer delitos punidos com pena privativa de liberdade ou medida de segurança de privação de liberdade de ao menos 4 (quatro) anos, consistindo estes delitos um fim em si mesmos ou um meio de obter benefícios patrimoniais e influir de maneira indevida no funcionamento da autoridade pública" (artigo $1^{\circ}$ da Ação Comum de 21.12.1998, relativa à tipificação penal da participação de uma organização criminosa nos Estados-membros da União Europeia);

${ }^{31}$ HASSEMER, Winfried. Segurança Pública no Estado de Direito, Revista Brasileira de Ciências Criminais, ${ }^{\circ}$ 5 , p. 59. 
Neste grupo, muito lembrada é a leitura realizada por Alberto Silva Franco $^{32-33}$, para quem o crime organizado, definido por seus elementos caracterizadores, "possui um caráter transnacional, na medida em que não respeita as fronteiras de cada país e apresenta características assemelhadas em várias nações; detém um imenso poder com base numa estratégia global e numa estrutura organizativa que lhe permite aproveitar as fraquezas estruturais do sistema penal; provoca danosidade social de alto vulto, tem grande força de expansão, compreendendo uma gama de condutas infracionais sem vítimas ou com vítimas difusas; dispõe de meios instrumentais de moderna tecnologia ${ }^{34}$; apresenta um intrincado esquema de conexões com outros grupos delinquentes e uma rede subterrânea de ligações com os quadros oficiais da vida social, econômica e política da comunidade; origina atos de extrema violência; exibe um poder de corrupção de difícil visibilidade; urde mil disfarces e simulações e, em resumo, é capaz de inerciar ou fragilizar os poderes do próprio Estado. É internacionalizado, institucionalizado, altamente hierarquizado e visa ao lucro. Não raro, explora tanto o que é lícito (mas escasso) quanto o que é ilícito ou moralmente reprovável por parcela da sociedade ${ }^{35-36,}$.

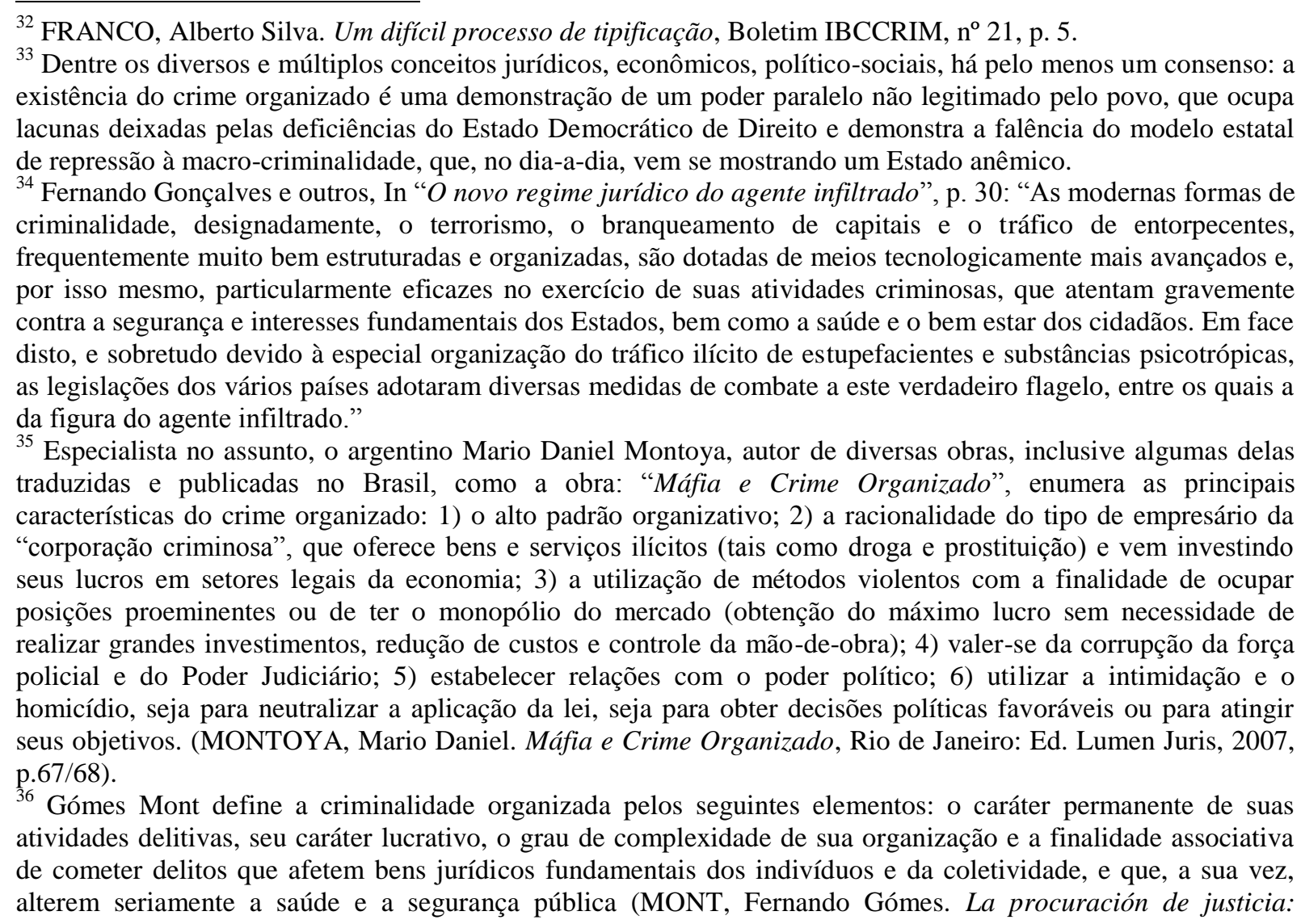


No âmbito da União Europeia, diversos grupos de trabalho vêm reconhecendo seis elementos que permitem identificar a existência de uma organização criminosa $^{37}:$ 1) concorrência de duas ou mais pessoas; 2) comissão de delitos graves; 3) ânimo de lucro; 4) distribuição de tarefas; 5) permanência e 6) atividade internacional ${ }^{38}$.

Como mencionado, há, ainda, uma terceira corrente ${ }^{39}$ que, para definir crime organizado, se utiliza do mesmo critério adotado para definição do crime hediondo (lei $n^{\circ} 8.072 / 90$ ), qual seja, conceitua o crime organizado através da enumeração das condutas (crimes) que o constituiriam, ou seja, por meio da listagem de um rol de crimes que seriam tipificados como crime organizado.

No Brasil a lei seguiu um caminho próprio. De pronto foi desprezada a linha sugerida pelo Projeto de lei $\mathrm{n}^{\mathrm{o}} 3.516^{40}$, que partia da noção de organização criminosa para definir o crime organizado.

problemas retos y perspectivas. Legislación vigente y poder de la delincuencia organizada: necesidad de reformas. México: Editorial Amanuense, 1994. p. 405). Para Reale Júnior é possível estabelecer os dados elementares caracterizadores da delinquência organizada tradicional mediante a atinência ao aspecto institucional da associação, com planejamento estratégico e hierarquia, que se organiza sob uma férrea disciplina de comando, valendo-se da violência para impor obediência e servilismo, sempre sob a exigência da lei do silêncio e fazendo da corrupção de agentes oficiais o instrumento garantidor de impunidade e facilitador de suas ações delituosas (JÚNIOR, Miguel Reale. Crime Organizado e Crime Econômico. Revista Brasileira de Ciências Criminais, São Paulo: RT, v. 4, nº 13, jan-mar, 1996, p. 184/185).

${ }^{37}$ Marcelo Batlouni Mendroni aponta os seguintes elementos caracterizadores das organizações criminosas no Brasil: 1) estrutura hierárquico-piramidal; 2) divisão direcionada de tarefas; 3) membros restritos; 4) agentes públicos participantes ou envolvidos; 5) orientação para a obtenção de dinheiro e de poder; 6) domínio territorial (in Crime Organizado, Aspectos gerais e mecanismos legais, Ed. Atlas, 2007, p. 13/17.). Já Eduardo Araujo da Silva elenca como principais características do crime organizado: 1) o alto poder de corrupção; 2) necessidade de legalizar o lucro obtido ilicitamente; 3) o alto poder de intimidação, com a prevalência da lei do silêncio; 4) conexões locais e internacionais; 5) divisão de territórios para a atuação; 6) estrutura piramidal e 7) forte relação com a comunidade. (in Crime Organizado, Ed. Atlas, 2007, p. 28/31). Francis Rafael Beck traz como elementos; 1) estrutura plúrima hierarquizada e permanente; 2) finalidade de lucro ou poder; 3) utilização de meios tecnológicos; 4) conexão com o poder público; 5) internacionalização; 6) uso da violência ou intimidação; 7) cometimento de delitos com graves consequências sociais e 8) emprego de lavagem de dinheiro (in Perspectivas de controle ao crime organizado e crítica à flexibilização das garantias. IBCCRIM, p. 80/91). Ver ainda Vicente Greco Filho e João Daniel Rassi, em Lei de Drogas Anotada, São Paulo: Saraiva, 2009, p.72 e ss.

38 BECK, Francis Rafael. In Perspectivas de controle ao crime organizado e crítica à flexibilização das garantias. IBCCrim, p. 79. Já Montalvo aponta que as três primeiras características seriam consideradas essenciais, enquanto as três últimas poderiam concorrer com as primeiras.

${ }^{39}$ Posição sugerida por Luiz Carlos Caffaro, O Ministério Público e o Crime Organizado, no X Congresso Nacional do Ministério Público, 1994, p. 24-37 e por Carlos Frederico Coelho Nogueira, A lei da "caixa preta". In: Penteado, Jaques de Camargo (coord.). Justiça Penal: críticas e sugestões, v. 3. São Paulo: RT, 1995, p. 154.

${ }^{40} \mathrm{O}$ projeto de Lei $\mathrm{n}^{\mathrm{o}} 3.516$ definia, no artigo $2^{\circ}$, a organização criminosa da seguinte forma: "aquela que, por suas características, demonstre a existência de estrutura criminal, operando de forma sistematizada, com atuação regional, nacional e/ou internacional". 
A Lei $\mathrm{n}^{\circ}$ 9.034/95 não trouxe a definição do que seja organização criminosa, nem relacionou as condutas que constituem crimes organizados ${ }^{41}$, deixando em aberto os tipos penais configuradores de crime organizado ${ }^{42}$. Pior que permitir essa lacuna foi a equiparação trazida por referida legislação, ao prever que qualquer delito pudesse ser caracterizado como de organização criminosa, desde que praticados por ações de bando ou quadrilha ${ }^{43-44}$. De fato, não se pode equiparar qualquer tipo de ação de quadrilha ou bando com ação de organização criminosa ${ }^{45-46}$.

\footnotetext{
${ }^{41}$ Antonio Scarance Fernandes conclui que "a Lei no 9.034/95 era necessária, pois o Brasil, como outros países, enfrenta problemas com o crime organizado. Contudo, ela contém falhas que deveriam ser superadas ou corrigidas pelas leis que a alteraram, mas não o foram. Assim, persistem os erros graves consistentes na falta de definição do que seja crime organizado ou organização criminosa e na sua aplicação a todos os delitos de bando ou quadrilha. Apesar da falta de definição a expressão "organização criminosa" é referida em outras leis para justificar graves restrições individuais, como a imposição de regime bastante rigoroso na execução penal, o regime disciplinar diferenciado". (Repressão Penal e Crime Organizado. Os novos Rumos da Política criminal após o 11 de setembro. In: $O$ equilíbrio entre a eficiência e o garantismo e o crime organizado. São Paulo: Ed. Quartier Latin, 2009, p.262).

${ }^{42}$ Neste sentido ressaltou Mario Daniel Montoya, quando analisa o crime organizado no Brasil: "A lei 9.034/95 não definiu o crime organizado baseando-se em seus elementos essenciais, nem pôs de manifesto os crimes que seriam qualificados como organizados. Assim, não se filiou a nenhuma das três linhas doutrinárias, admitindo que qualquer crime tipificado em outras leis penais poderia ser considerado desse modo, bastando para isso que fosse praticado por uma quadrilha ou um bando". In Máfia e Crime Organizado, Rio de Janeiro: Editora Lumen Juris, 2007, p. 225.

${ }^{43}$ Artigo $1^{\circ}$ da Lei $n^{\circ}$ 9.034/95: "Esta Lei define e regula meios de prova e procedimentos investigatórios que versem sobre crime resultante de quadrilha ou bando".

${ }^{44}$ Para Geraldo Prado e William Douglas nesse ponto a Lei $\mathrm{n}^{\circ}$ 9.034/95 foi infeliz, pois se sabe que nem todas as quadrilhas cometem crimes de forma tão organizada e estruturada, existindo mesmo as chamadas "quadrilhas de bagatela”. (in Comentários à lei contra o crime organizado. Belo Horizonte: Del Rey, 1995. p. 42).

${ }^{45}$ Também Paulo César Correa Borges adverte: "existem muitas quadrilhas ou bandos que são totalmente desorganizados e que jamais poderiam ser consideradas organizações criminosas com base nos critérios doutrinários (in $O$ crime organizado, p. 20). No mesmo sentido Guilherme de Souza Nucci ao considerar frágil a inclusão na lei do crime organizado da simples menção de quadrilha ou bando (In Leis Penais e Processuais Penais Comentadas, São Paulo: RT, 2006, p. 200). Na visão de Luiz Flávio Gomes o legislador deu ao crime organizado "o mínimo, que é o crime de quadrilha ou bando, e deixou por conta do intérprete a tarefa de fixar os restantes contornos da organização criminosa" (in GOMES, Luiz Flávio; CERVINI, Raúl. Crime Organizado: enfoque criminológico, jurídico e político-criminal. São Paulo: RT, 1995. p. 68/78). Mario Daniel Montoya especula que: "apesar de a organização criminosa ser muito mais complexa do que a simples quadrilha ou bando, não deixa de ser uma forma de associação criminosa entre duas ou mais pessoas. Talvez por essa razão, a Lei 9.034/95 faça referência a ela da mesma forma que o artigo 288 do Código Penal (in Máfia e Crime Organizado, Lumen Juris, p. 226).

${ }^{46}$ Fausto Martin de Sanctis frisa que: "O desenvolvimento do crime organizado apresenta-se dissimulado ou encoberto por atividade comercial ilícita. Não se confundiria com a prática antiga do delito de quadrilha ou bando (art. 288 do CP), no qual havia singelo concerto para a prática de crimes. Em ambos há estabilidade e permanência, mas a organização criminosa é revestida de peculiaridades próprias, mesmo aquelas de índole regional (dentro das fronteiras de um país). Não se cuida, pois, de identidade de conceitos, porquanto inconfundíveis, uma vez que o conceito de crime organizado sempre envolve estrutura complexa e, de certa forma, profissionalizada. In: Crime Organizado e destinação de bens apreendidos. São Paulo: Editora Saraiva, 2009 , p. $7 / 8$.
} 
Posteriormente, a Lei $\mathrm{n}^{\mathrm{o}}$ 10.217/01 alterando a anterior e tentando sanar tal vício acabou por complicar ainda mais. Isto porque a nova redação do artigo $1^{\circ}$ da Lei $n^{\circ}$ $10.217 / 01^{47}$ passou a se referir a três figuras: a) quadrilha ou bando ${ }^{48}$; b) organização criminosa $^{49}$ e c) associação criminosa ${ }^{50}$, novamente sem as diferenciar expressamente e persistindo na falha originária da lei, ao continuar aplicando os seus dispositivos à quadrilha ou bando, nivelando-os, neste aspecto, à organização ou associação criminosa. Soma-se a isto a continuidade da ausência de definição legal das organizações criminosas ${ }^{51-52}$.

47 Dispõe o artigo $1^{\circ}$ da Lei $n^{\circ}$ 10.217/01: "Esta lei define e regula meios de prova e procedimentos investigatórios que versam sobre ilícitos decorrentes de ações praticadas por quadrilha ou bando ou organizações ou associações criminosas de qualquer tipo".

${ }^{48}$ Quadrilha ou bando é a associação de mais de três pessoas, com a finalidade de praticar crimes, desde que haja estabilidade e durabilidade, nos termos tipificados pelo artigo 288 do Código Penal. Pedro Franco de Campos adverte que não se pode confundir a tipificação de quadrilha ou bando com o concurso de pessoas, pois na quadrilha há associação estável e com o fim de cometer um número indeterminado de crimes. Já no concurso de agentes, a associação é eventual e visa o cometimento de determinado(s) crime(s), in Direito Penal Aplicado. Parte Especial. São Paulo: Editora Saraiva, 2008, p. 295.

${ }^{49}$ Para Élio Wanderley de Siqueira Filho a expressão "organizações criminosas" dá a ideia de pessoas jurídicas de direito ou de fato as quais cometem crimes, o que é atípico na legislação penal comum, a não ser em relação aos crimes contra o meio ambiente. Apesar dessa imprecisão terminológica a lei do crime organizado traz em seu bojo tal expressão. In: Repressão ao crime organizado: inovações da lei 9.034/95. Curitiba: Juruá, 1995, p. 19.

${ }^{50} \mathrm{Na}$ análise das alterações trazidas pela Lei 10.217/01, Luiz Flávio Gomes compara: "o ordenamento penal define quadrilha ou bando no artigo 288 do Código Penal. Pode-se igualmente ter acesso à noção de associação criminosa, por exemplo, nos artigos 14 e 18, inc. III, da lei de tóxicos e no artigo $2^{\text {a }}$ da lei do genocídio. Todavia, não existe em nenhuma parte de nosso ordenamento jurídico a definição de "organização criminosa": cuida-se, portanto, de um conceito vago, totalmente aberto, absolutamente poroso. Considerando-se que (diferentemente do que ocorria antes) o legislador não ofereceu sequer a descrição típica mínima do fenômeno, só nos resta concluir, nesse ponto, a Lei (9.034/95) passou a ser letra morta. Organização criminosa, portanto, hoje, no ordenamento jurídico brasileiro, é uma alma (uma enunciação abstrata) em busca de um corpo (de um conteúdo normativo, que atenda o princípio da legalidade)". In: Crime organizado: o que se entende por isso depois da Lei 10.217, de 11.04.2001? Apontamentos sobre a perda da eficácia de grande parte da Lei 9.034/95. Revista dos Tribunais, São Paulo, v. 91, nº 795, jan. 2002, p.488.

${ }^{51}$ Mesmo sem definir organizações criminosas, o legislador usou essa expressão em alguns dos seus dispositivos, como nos arts. $4^{\circ}, 5^{\circ}, 6^{\circ}$, o que também aconteceu em outras leis, como a lei de execução penal, na parte

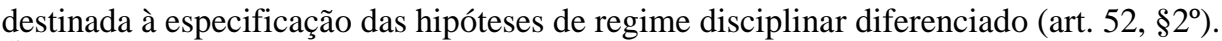

${ }^{52}$ Com relação à falta de definição legal acerca do crime organizado observam Luciana Ferreira L. Pinto e Tatiana Bicudo: "É evidente que o crime organizado está a demandar um estudo sério e aprofundado e que o direito penal deve, nesse caso, posicionar-se de maneira nítida, preenchendo, sem recorrer a argumentos emocionais ou políticos, o conteúdo do conceito. Mas daí a aceitar, pura e simplesmente, pelo prazer de atender aos reclames de determinados segmentos sociais, uma definição vesga e coxa da criminalidade organizada e referendar meios investigatórios e de prova que lesionam as garantias processuais de conotação constitucional, há uma distância muito grande que ninguém, de visão democrática, estará disposto a trilhar" (In: A lei contra o crime organizado exige debate mais sério, por toda a sociedade. Boletim IBCCRIM, $\mathrm{n}^{\circ}$ 12, p.1, jan. 1994). Expõe Ricardo Alves Bento que: "o crime organizado, ainda que pendente de conceito expresso, sem prejuízo de ratificações de tratados internacionais (notadamente a Convenção de Palermo), é um vertente que assola a sociedade brasileira, e nos termos do devido processo legislativo material, incumbe ao Poder legislativo a edição de medidas eficientes para responder a estes acontecimentos (Agente Infiltrado - Busca pela legitimação constitucional. In: Limites...Op. cit. p. 345). 
Vicente Greco Filho aponta que: "há quem sustente, contudo sem razão, que no Brasil existe definição legal de associação criminosa e que ela se encontra na chamada Convenção de Palermo"53 , já que o Brasil é signatário deste Tratado Internacional.

Consoante disposto no artigo $2^{\circ}$, alínea a, da referida Convenção, entende-se por grupo criminoso organizado; "grupo estruturado de três ou mais pessoas, existente há algum tempo e atuando concertadamente com o propósito de cometer uma ou mais infrações graves ou enunciadas na presente Convenção, com a intenção de obter, direta ou indiretamente, um benefício econômico ${ }^{54}$ ou outro benefício material” ${ }^{, 55}$.

No entanto, observa Vicente Greco $^{56}$ que "a conceituação trazida pela Convenção de Palermo é imprestável para o Direito Brasileiro, eis que não estabelece requisitos distintivos entre a nossa 'quadrilha ou bando' e o 'grupo criminoso organizado', distinção hoje necessária para os efeitos penais e processuais penais".

Fato é que persiste aberta a discussão, não apenas no tocante à existência da definição de crime organizado no Brasil, mas também se a lei deveria, deve ou deverá estabelecer os requisitos para que uma associação ou grupo se constitua em organização

${ }^{53}$ Conforme lição de Vicente Greco Filho: A Convenção de Palermo é o nome pelo qual é mais conhecida a Convenção das Nações Unidas contra o Crime Organizado Transnacional, apesar de editada em Nova York tendo em vista ter sido decorrente de três instrumentos firmados na capital da Sicilia. Foi adotada em Assembléia da Organização das Nações Unidas (ONU), no mês de novembro de ano de 2000. No Brasil, a Convenção de Palermo foi promulgada pelo decreto 5.0155, de março de 2004. No âmbito da organização dos Estados Americanos (OEA), a Convenção de Palermo foi objeto de Resolução, aprovada na XXX Assembléia Geral, contando com o apoio do governo brasileiro (in: A entrega vigiada e suas repercussões penais. Op. cit.).

${ }^{54}$ Eduardo Araujo da Silva bem observa que a Convenção de Palermo ao acrescentar a finalidade econômica, tal aproximação conceitual busca, conforme a tendência contemporânea no plano internacional, diferenciar no terreno jurídico-penal os conceitos de organização criminosa e terrorismo, ante a prevalência neste último do conteúdo ideológico. In: Crime Organizado, Op. Cit, p. 35.

${ }^{55}$ Para Fernando Capez, com a definição de crime organizado trazida pela Convenção de Palermo, a tendência é a de que acabe a restrição quanto à incidência da Lei de crime organizado sobre as organizações criminosas, sob o argumento de que não foram definidas em lei, passando os dispositivos previstos na Lei $\mathrm{n}^{\circ}$ 9.034/95 e alterados pela Lei $\mathrm{n}^{\circ} 10.271 / 01$ a ter incidência sobre os grupos com as características apontadas pela Convenção (in: Curso de Direito Penal. Legislação Especial, vol. 4, São Paulo: Saraiva, 2006, p. 234). Para Rodrigo Carneiro Gomes: "Com a edição do Decreto 5.015, de 2004, surge a obrigação jurídica internacional de o legislador pátrio, nas proposições legislativas, observar os traços delineadores do que seja crime organizado. Com a incorporação da Convenção de Palermo ao ordenamento jurídico pátrio, estabelece-se a definição de grupo organizado, mas que imprescinde de lei penal em sentido estrito", In: O crime organizado na visão da Convenção de Palermo, Belo Horizonte: Del Rey, 2009, p. 19.

${ }^{56}$ Op. Cit. p. 4. 
criminosa $^{57}$. Parte considerável da doutrina ${ }^{58}$ sustenta que as organizações criminosas são muito diferenciadas e uma definição restringiria o conceito, tornando impossível a sua identificação em face de exigências rígidas e expressas.

A falta de definição de organização criminosa, como pondera Antonio Scarance Fernandes ${ }^{59}$, “impossibilita a restrição a direitos e garantias ${ }^{60}$ do investigado, do acusado, do condenado, com fundamento no fato de pertencer a esse tipo de entidade, por ofensa aos princípios da reserva legal e da proporcionalidade. Como realçado, não se pode utilizar medidas excepcionais contra o indivíduo, com base no princípio da proporcionalidade, sem que se atenda ao pressuposto da legalidade" ${ }^{, 61}$.

\subsection{Política criminal de combate à criminalidade moderna}

\footnotetext{
${ }^{57}$ Relevante observação de Rodrigo Carneiro Gomes: "Levando em consideração tão-somente a pluralidade de agentes, a legislação brasileira abre um leque de delitos. Quando há pelo menos dois criminosos para fins de tráfico de drogas (art. 35, da Lei 11.343/06); pelo menos três criminosos para a prática de delitos reprimidos pela Convenção de Palermo: participação em grupo criminoso organizado (art. $2^{\circ}$, a, do anexo do Dec. 5.015/2004, que promulgou a CCOT); e ao menos quatro criminosos: quadrilha ou bando (art. 288 do CP), in: Limites constitucionais da investigação no Brasil. Investigação criminal na Convenção de Palermo: instrumentos e limites, p. 359.

${ }^{58}$ Para Francis Rafael Beck: "Qualquer conceito que poderia ser utilizado há duas ou três décadas certamente não se adequaria à maior parte dos casos atuais de suposta existência de criminalidade organizada. Com a globalização da economia e revolução das formas de comunicação e transferência de dados e informações, mesmo um conceito formulado há poucos anos já poderia restar completamente desatualizado, obsoleto. Eis a (simples) razão pela qual se abdica de formular um conceito de crime organizado. (Op. Cit. p. 74). Para Mário Sérgio Sobrinho, a presença de grupos organizados no território nacional e a precariedade da legislação que cuida desse tema no Brasil, permitem concluir ser preciso criar regras objetivas para punir as pessoas envolvidas com essa modalidade criminosa. In: Crime Organizado. São Paulo: RT, 2009, p. 35.

${ }^{59}$ Essa conclusão foi extraída no curso de pós-graduação sob a coordenação de Antonio Scarance Fernandes, José Raul Gavião de Almeida, Maurício Zanoide de Moraes, cujas discussões resultaram na publicação da obra: “Crime Organizado, Aspectos Processuais", São Paulo: RT, 2009.

${ }^{60}$ A partir do princípio da taxatividade penal, Luiz Vicente Cernicchiaro afirma que "não há, no Brasil, crime resultante de organização criminosa!". O autor se baseia na falta de definição legal desse instituto e diz em reforço à sua ideia, ser "inadmissível, ademais, interpretação extensiva para capitular novas condutas, no direito penal do fato, cujos limites, sem dúvida, são coordenados pelo garantismo jurídico!" (in: Organização criminosa, Direito penal especial, processo penal e direitos fundamentais: visão luso-brasileira. São Paulo: Quartier Latin, 2006. p. 201).

${ }^{61}$ Para não ferir os direitos individuais, ante a falta de definição legal, que pode ser bastante prejudicial ao investigado, Guilherme Madeira Dezem e Evandro Fernandes de Pontes afirmam que ante a falta de definição de organização criminosa no direito brasileiro, deveria aplicar-se aquela constante da Convenção de Palermo, incorporada ao ordenamento nacional pelo Dec. 5.015/2004.
} 


\section{A resposta do Estado para o controle e combate à criminalidade}

organizada não deve ocorrer por meio de adoção de uma política criminal unicamente repressiva $^{62-63}$, com supressão de garantias, visando apenas punir com mais severidade, consoante ocorrido com a Lei dos crimes hediondos (Lei nº 8.072/90), que existe há quase vinte anos e não acabou com os tipos de crime enumerados em sua norma ${ }^{64}$.

\section{O terror que este tipo de criminalidade instaura na população é} aproveitado por movimentos políticos que apresentam um "remédio milagroso"- amparado na ideologia da repressão ${ }^{65}$ - que nada mais é do que o velho regime punitivo-retributivo ${ }^{66}$, que agora recebe o nome de "movimento de Lei e Ordem".

${ }^{62}$ Carlos Frederico Nogueira observa que a Lei $\mathrm{n}^{\mathbf{0}}$ 9.034/95, criada para combater o crime organizado, com a intenção de seguir o modelo italiano "Operações mãos limpas", é inócua e contraproducente, não podendo ser comparada a estrutura brasileira com a estrutura italiana para o combate eficiente e adequado dessa criminalidade: "Aqui, se um esquema de repressão à criminalidade organizada, ou megacriminalidade, se baseasse em normas pífias como a lei $\mathrm{n}^{\circ}$ 9.034/95, o resultado seria, quando muito, uma operação mani vuote (mãos vazias), pois nada, ou quase nada seria possível seguir" (in: A lei da caixa preta. Revista Justitia, v. 172, 1995, p.11).

${ }^{63}$ Para enfrentar o crime organizado é preciso atuar não apenas de forma repressiva, mas também - e principalmente - na forma preventiva. Conforme apresentado por Mariângela Lopes: "político-criminalmente, existem duas vias de reação: as que atuam antes do cometimento dos delitos, ante factum, e as que se manifestam após a ocorrência desses delitos, post factum (TOMÉ, Mariângela Lopes. Dissertação de Mestrado da Universidade de São Paulo: "O agente infiltrado como meio de investigação", 2006, p. 24). Segundo a moderna criminologia a prevenção dar-se-ia de três formas: a primeira é uma concentração na raiz dos problemas, onde seria importante uma política social de investimento em, primeiro lugar, educação, inclusão social, trabalho, saúde etc; a segunda seria a criação de obstáculos à atividade criminosa, não se concentrando nas causas, como a existência de mais policiais, mais segurança, em uma forma na qual a sensação psicológica de proteção seria enfatizada; a terceira só interviria quando do já cometimento do crime, como medidas que visassem a não reincidência do criminoso. In: García-Pablos de Molina. Apud Gomes, Luiz Flávio; Cervini, Raúl. Crime Organizado. Op. Cit. p. 44.

${ }^{64}$ Francisco de Assis Toledo sustenta que para "crimes de especial severidade", atos de grande violência onde se empregam meios cruéis, deva haver um tratamento penal também especial, porém sem se cair na radicalização da lei dos crimes hediondos, a qual considera excessiva (TOLEDO, Francisco de Assis. A modernização das leis penais. In: Jaques de Camargo Penteado. Justiça Penal: críticas e sugestões, vol. 3. São Paulo: RT, 1995).

${ }^{65}$ A repressão com leis mais severas só terá efeito se houver uma motivação às pessoas para que elas ajam de acordo com a lei e essa motivação é uma rápida e eficiente aplicação da norma penal, pois como escreveu Beccaria: "não é o rigor do suplício que previne os crimes com mais segurança, mas a certeza do castigo". (BECCARIA, Cesare. Dos delitos e das penas. São Paulo: Martin Claret, 2001).

${ }^{66}$ Miguel Reale Junior tece crítica às legislações adotadas nos governos de Fernando Collor e Fernando Henrique. Para o jurista, o direito penal "Fernandino" fez da década de 90 um dos momentos mais dramáticos para o Direito Brasileiro, pois era imprevisível que se produzissem em matéria repressiva tantas soluções normativas ao sabor dos fatos, sob o encanto de premissas falsas e longe de qualquer técnica legislativa. $\mathrm{O}$ elenco de leis penais esdrúxulas, eivadas de inconstitucionalidades. Op. cit. p.35. 
Em se tratando da repressão ao delito organizado, cada dia mais se avança em direção a um direito especial ou de exceção. Para Adriasola ${ }^{67}$, "esta postura não importa em aceitar a renúncia às garantias do direito clássico, mas apenas reconhecer a sua 'insuficiência' diante desta nova realidade criminal. Trata-se, em última análise, de uma decisão de política criminal que os legisladores e operadores de direito deverão adotar ou rechaçar, não deixando o autor supracitado de reconhecer que o direito emergencial ${ }^{68-69}$ quebra todo o paradigma do direito penal e processual penal liberal, destinado a garantir a esfera de liberdade do indivíduo diante do Estado". Em outras palavras, criou-se a ideia da admissão de um tratamento penal diferenciado, mais repressivo e acirrado, justamente porque deve combater uma espécie de criminalidade diversa (a criminalidade organizada), justificado pelo caráter de emergência na luta contra a prática de crimes que corroem os alicerces do próprio Estado de Direito, além da admissibilidade de métodos excepcionais de investigação ${ }^{70}$.

${ }^{67}$ ADRIASOLA, Gabriel. El nuevo derecho sobre toxicos e el lavado de dinero de la droga. Montevidéo: Fundación de Cultura Universitaria, 1994, p. 97.

${ }^{68}$ Segundo o jurista italiano Luigi Ferrajoli deve entender-se por direito penal de emergência duas coisas: uma jurisdição de exceção e uma legislação penal excepcional frente à Constituição (FERRAJOLI, Luigi. Diritto $e$ Ragione. Roma: Laterza, 1990, p. 844 e ss.). Também Gomes e Cervini explicam que: "a característica marcante do direito de exceção (já enfatizado, de resto, por Ferrajoli) reside na formação de um direito 'paralelo', pouco ajustado aos direitos e garantias fundamentais e aos princípios básicos do Estado Constitucional de Direito. É guiado, por outro lado, pela política criminal apenas preocupada com a eficiência do sistema, com êxito funcional, enfim, com ter respostas ('imediatas', ainda que muitas vezes 'simbólicas') para a criminalidade dentro de uma concepção criminológica "neoclássica"” (GOMES E CERVINI. Op. Cit. p. 67). Como recorda Rinaldi, as mais importantes disposições legislativas relacionadas à máfia, entre os anos 80 e princípio dos 90 , não se originaram de uma estratégia mediata e consciente de intervenção, mas foram promulgadas em reação a ataques violentos aos representantes do Estado ou da sociedade civil. A cada ruptura do modelo de normalidade, introduzem-se novas disposições normativas (RINALDI, Stanislao. Criminalidade organizada de tipo mafioso $e$ poder político na Itália. Revista Brasileira de Ciências Criminais, São Paulo: RT, v. 6, no 22, abr-jun, 1998, p. 21/22). Em suma, a emergência significa, portanto, um desvio aos padrões tradicionais do sistema repressivo, estabelecendo um subsistema que se afasta das normas e princípios válidos para a normalidade. Aponta Hassan Choukr que a ideia de emergência está atrelada à ideia de urgência (e, num certo sentido, à de crise), a algo que, de forma repentina, surge de modo a desestabilizar o status quo ante e os padrões normais de comportamento e possibilidade de manutenção das estruturas. Ademais, a expressão se atrela à necessidade de uma resposta pronta e imediata, que deve durar enquanto o estado emergencial perdura. (CHOUKR, Hassan Fauzi. Processo penal de emergência. Rio de Janeiro: Lumen Juris, 2001, p.1-2).

${ }^{69}$ Exemplo clássico de utilização do direito penal emergencial foi o combate italiano à máfia existente neste país, criando legislação rígida nas áreas: leis anti-terrorismo; leis anti-sequestro; leis anti-máfia, além de medidas como a delação premiada, sem falar nas mudanças nos códigos e legislação ordinária. Houve um racha entre os apoiadores da medida, principalmente juízes e promotores que aplaudiram as mudanças em contrapartida à classe que eram contra, formadas essencialmente por advogados e juristas.

${ }^{70}$ Para Mário Sérgio Sobrinho: "A apuração de infrações penais é realizada, em geral, por meios comuns de investigação, como os testemunhos e as perícias previstos no Código de Processo Penal. Já a criminalidade organizada, por suas características peculiares, exige o emprego de meios especiais de investigação ou de obtenção de provas para sua apuração". Op. cit. p. 38 . 
O legislador brasileiro, seguindo essa propensão jurídico-criminal no terreno processual e a par da sinalização contida na Constituição Federal de 1988 - quanto à possibilidade de tratamentos distintos conforme a gravidade de certas formas de crime - editou diversas leis destinadas, direta ou indiretamente, ao combate do crime organizado, no intuito de agravar as penas para esta forma de criminalidade ${ }^{71}$.

Todavia, antes de criar qualquer medida no combate ao crime, é imprescindível verificar se os limites da Constituição não estão sendo violados ${ }^{72}$. Tal providência se traduz em verdadeira barreira para toda e qualquer política criminal que pretender ultrapassar seus limites. Obviamente que a criminalidade mais grave e excepcional como a organizada requer um tratamento diferenciado, excepcional. Contudo, respeitando-se as regras do Estado Democrático de Direito.

Muitas vezes o legislador sabe que essa política criminal é ineficaz, mas faz de conta que está inquieto, preocupado e que reage imediatamente ao grande problema da criminalidade, configurando uma política desonesta que retira a credibilidade do Direito Penal.

Diante destas constatações, a questão que se estabelece é a de valorar até que ponto o sistema penal se encontra em condições de fazer frente à criminalidade organizada com amparo em um instrumento penal garantista ${ }^{73-74}$.

\footnotetext{
${ }^{71}$ Eduardo Araujo da Silva faz uma longa e minuciosa análise de referida legislação, que passamos a listar de forma resumida: a) lei $\mathrm{n}^{\circ}$ 9.034/95, destinada ao tratamento específico do crime organizado; b) Lei ${ }^{\circ}$ 9.296/96, que embora não seja voltada especificamente para a apuração da criminalidade organizada, regulamentou a viabilidade das comunicações telefônicas e do fluxo de comunicações em sistemas de informática e telemática; c) Lei $\mathrm{n}^{\circ}$ 9.613/98, que dispõe sobre os crimes de lavagem de dinheiro; d) a Lei $\mathrm{n}^{\circ}$ 9.807/99 estabeleceu normas para a organização e a manutenção de programas especiais de proteção às vítimas e testemunhas ameaçadas; e) a Lei $\mathrm{n}^{\mathrm{o}} 10.217 / 01$ introduziu os incisos IV e V no artigo $2^{\circ}$ da lei ${ }^{\circ} 9.034 / 95$, disciplinando as figuras da interceptação ambiental de sinais e infiltração de agentes da polícia ou da inteligência; f) a Lei complementar $\mathrm{n}^{\circ}$ 105/01 dispôs sobre o sigilo das operações de instituições financeiras; g) Lei ${ }^{\circ} 7.492 / 86$, chamada de lei do colarinho branco, dentre outras. Op. Cit. p. 50/53.

${ }^{72}$ Não é demais lembrar a lição de Cervini e Luiz Flávio Gomes na qual toda e qualquer política criminal deve ter como limite o Estado Constitucional de Direito. Op. cit. p. 47.

${ }^{73}$ As opções de respostas elaboradas pela doutrina podem esquematizar-se em três grandes linhas. Para a primeira delas, os enfoques do direito penal garantista devem ser igualmente observados em relação às novas formas de delinquência, aplicando-se os instrumentos de dogmática e princípios de atribuição já conhecidos, mesmo que se cogite que esse modelo não possibilite um resultado eficaz. A segunda, em contrapartida, sustenta uma flexibilização de tais instrumentos, regras e princípios já assentados, com intenção de controlar mais eficazmente as formas de criminalidade hoje verificadas, adaptando o direito penal aos novos tempos. A linha
} 
A solução apontada para o eficaz combate aos ilícitos, assim caracterizados, baseia-se no estabelecimento de políticas de conteúdo não somente no campo jurídico, mas também no social ${ }^{75}$, educacional, econômico e administrativo, tanto no campo preventivo como no repressivo e, sobretudo, com respeito aos direitos e garantias individuais $^{76}$.

\subsection{Meios de investigação e meios de formação da prova}

\section{Tem sido comum a inserção de novos meios de investigação nos diplomas} processuais penais ou em leis extravagantes, objetivando a obtenção de provas, especialmente as que possibilitem conter o crime organizado, por meio de uma persecução penal mais efetiva.

derradeira sustenta a renúncia da expansão dos preceitos penais a estes novos âmbitos de atuação, por considerar que não correspondem eles à tarefa própria do direito penal, que com isso perderia a sua identidade e justificação. (Cf. Buergo, 2001, p. 60-61. In: Frascis Rafael Beck, Op, cit. p. 106).

${ }^{74}$ Jesús-María Silva Sánchez observa que, frente ao fenômeno da criminalidade organizada, impõe-se que algumas garantias processuais sejam "reinterpretadas", razão pela qual, nos dias atuais, entende inevitável reformas antigarantistas para a apuração de certas formas de crime (La expansión...Op. Cit. p. 17-18 e 41-42). Na mesma linha Vicente Garrido et al., para os quais os Estados democráticos estão sendo obrigados a tratar de suas polícias e sistemas de justiça com medidas especiais para fazer frente àqueles que não respeitam nenhuma regra (Princípios...Op. cit. p. 647). Ainda a respeito da necessidade de redimensionamento de algumas garantias processuais, v. Román Julio Frondizi e Maria Gabriela Silvina Daudet. Garantías...Op. Cit. p. 182-183.

${ }_{75}$ Marco Antonio Rodrigues Nahum adverte que: "Ao invés de leis mais severas impõe-se o investimento de recursos sociais, concomitantemente a uma constante política de agilização e valorização do Poder Judiciário, somadas à estruturação científica de nossa polícia e racional política penitenciária. Somente uma ampla política social, prestigiada de maneira uniforme pelos três Poderes valorizados, combate a criminalidade sem ofender a cidadania" (NAHUM, Marco Antonio Rodrigues. A Repressão ao Crime, e o Antiterrorismo, Boletim IBCCRIM - ano 11, n. 128, julho, 2003, p.2).

${ }^{76}$ Para William Douglas e Geraldo Prado o primeiro passo é o estabelecimento de um programa nacional de combate à criminalidade, cujas diretrizes podem ser adaptadas - completamente - por cada Unidade da Federação. Como proposta os autores sugerem: a) a manutenção do indispensável equilíbrio entre o exercício da repressão e a garantia efetiva dos direitos individuais; b) educação jurídica popular; c) profissionalização dos órgãos e seu comando; d) revisão dos códigos, dentre outras tantas sugestões de alterações legislativas propostas, com a observação dos autores de que as referidas sugestões dependem de iniciativa legislativa conjugada com atuação administrativa, além do que exigem maior entrosamento entre o Executivo (polícias, penitenciárias, demais órgãos relacionados com a execução penal), Ministério Público e Judiciário. (DOUGLAS, William; PRADO, Geraldo. Comentários à Lei contra o crime organizado, Ed. Impetus, 2001, p. 114/117). 
Desta forma, imperiosa se faz a análise das características definidoras de um meio de investigação da prova, que auxiliará, sobremaneira, no entendimento da própria técnica da entrega vigiada.

$\mathrm{Na}$ terminologia processual distinguem-se as expressões: fontes de prova $^{77}$, meios de prova ${ }^{78}$ e meios de investigação (ou meios de pesquisa).

\section{Consoante Antonio Magalhães Gomes Filho ${ }^{79}$ entende-se por fonte de} $\operatorname{provas}^{80}$ pessoas ou coisas das quais pode se conseguir o elemento de prova. A fonte de prova $^{81}$ pode ser classificada em fontes pessoais (como: as testemunhas, os peritos, a vítima, o acusado) e fontes reais (os documentos, por exemplo).

Já os meios de prova ${ }^{82}$ podem ser entendidos como os instrumentos ou atividades por intermédios das quais os elementos de prova são introduzidos ao processo. São

${ }^{77}$ Sobre o tema de prova pode-se destacar, dentre outros, alguns autores de renome que tratam do assunto: Antonio Magalhães Gomes filho, Giulio Ubertis, Ennio Amodio, Mirjan Damaska, Michele Taruffo, Marina Gascón Abellán. Com relação a estes dois últimos, vale descrever o enfoque dado ao emprego do termo prova, de maneira a reforçar seu conteúdo polissêmico: Para Gascón Abellán o termo prova é polissêmico, pois se usa para fazer referência a questões diversas. Ademais, dentro das distintas acepções do termo, se operam, tanto na doutrina como na jurisprudência, algumas distinções que nem sempre são usadas no mesmo sentido, de maneira que o resultado final é um enorme caos terminológico onde reina a incoerência (ABELLAN, Gáscon. Los hechos en el derecho - Bases Argumentales de la prueba. Madrid: Marcial, Pons, Ediciones Jurídicas y Sociales S. A., 1999, p.83). Para Taruffo: "é a circunstância que na cultura jurídica italiana, assim como também nas culturas jurídicas, não usadas somente definições estáveis e rigorosas dos conceitos que se detêm à problemática da prova" (La prova dei Fatti Giuridici - Nozioni Generali. Milano: Dott. A. Giuffrè Editore, 1992, p. 413).

${ }^{78}$ Gustavo Badaró lembra que o primeiro a chamar a atenção para a distinção entre fontes e meios de prova foi Carnelutti. Já para Chiovenda meios de prova são as fontes de que o juiz extrai os motivos de prova. De forma semelhante, para Pontes de Miranda "meios de prova são as fontes probantes, os meios pelos quais o juiz recebe os elementos ou motivos de prova". Op. cit. p.163.

${ }^{79}$ FILHO, Antonio Magalhães Gomes. Op. cit. p. 308.

${ }^{80}$ Gustavo Badaró esclarece que "as fontes de prova decorrem do fato em si, independentemente da existência do processo. Ocorrido o fato, tudo aquilo que puder servir para esclarecer alguém sobre a existência desse fato pode ser considerado como fonte de prova daquele fato. Adverte o autor que as fontes de prova são anteriores ao processo e sua introdução no processo é feita através dos meios de prova. (BADARÓ, Gustavo Henrique Righi Ivahy. Ônus da Prova no Processo Penal. São Paulo: Editora RT, 2003, p. 165).

${ }^{81}$ Para Carnelutti, fontes de prova são "fatos dos quais o juiz se serve para deduzir a verdade", enquanto os meios de prova são "a atividade do juiz mediante a qual busca a verdade de um fato a se provar" (La prova Civile, p. 83). Para Dinamarco "os elementos externos em si mesmos, quando considerados em sua aptidão a fornecer indicações úteis ao julgamento, são fontes de prova. São fontes de prova pessoas e coisas. Uma pessoa ferida ou doente, um papel escrito, um veículo destruído, um imóvel danificado, uma contabilidade, são fontes de prova" (Instituições de Direito Processual Civil, vol. II. São Paulo, Malheiros, 2001, p.611).

${ }^{82}$ Conforme Antonio Magalhães Gomes Filho: "Os meios de prova referem-se a uma atividade endoprocessual, que se desenvolve perante o juiz, como conhecimento e participação das partes, visando à introdução e a fixação de dados probatórios no processo" (FILHO, Antonio Magalhães Gomes. Notas sobre a terminologia da prova 
os canais, as vias de informação de que servem as partes ou o juiz. Classicamente os meios de prova são: testemunhal, documental e pericial. Embora haja discussão e admissão de outros meios de prova.

\author{
Por fim, fala-se em meios de investigação da prova ${ }^{83}$. Conforme exposto
} por supracitado autor "os meios de pesquisa ou de investigação da prova dizem respeito a

(reflexos no processo penal brasileiro) in Estudos em homenagem à Professora Ada Pellegrini Grinover. Yarshell, Flavio Luiz e Moraes, Maurício Zanoide de (orgs.). São Paulo, DPJ, 2005, p. 305). Luigi Paolo Comoglio ao definir meios de prova aponta que: "são todos caracterizados pelo propósito de oferecer ao juiz resultados probatórios diretamente utilizados com o fim de decidir, e então tem naquele juiz o próprio destinatário natural" (COMOGLIO, Luigi Paolo. Considerazioni Inattuali Sulla Notificazione dell'impugnazione. Rivista di Diritto Processuale, anno I, no 4. Casa Editrice Dott. Antonio Milani, 1995, p. 1206). Michele Taruffo observa os meios de prova: "Piú precisamente si parla a questo proposito di 'mezzi di prova' (medios di prueba, Beweissmittel) per sottolineare che inquesto senso è prova ciò che serve a provare, ossia ogni elemento che possa essere impiegato per la conoscenza del fatto" (TARUFFO, Michele. Op.cit, p. 421). Fauzi Hassan Choukr define meio de prova como: "o mecanismo empregado para a obtenção de um conteúdo, este sim a prova em si. Desta forma a testemunha não é a prova, mas seu depoimento sim; a interceptação não é prova, mas o conteúdo da degravação etc." (Código de Processo Penal - Comentários Consolidados e Crítica Jurisprudencial. Rio de Janeiro: Editora Lumen Juris, 2005, p.285). Marina Gascón Abellán afirma que "meio de prova denota tudo aquilo que permite conhecer dos fatos relevantes da causa; é dizer, o que permite formular ou verificar os enunciados assertivos que servem para reconstruir estes fatos. Os meios de prova desempenham uma função cognoscitiva dos fatos que se pretendem provar" (ABELLÁN, Marina Gascón. Op. cit. p. 84).

${ }^{83}$ No CPP em vigência, no tocante ao capítulo de provas, não há distinção entre meios de provas e meios de obtenção de provas. Isto porque o diploma processual penal em vigor não disciplina de forma sistemática os meios de prova, dando a impressão, à primeira vista, ter relacionado apenas os meios de prova, já que não há tratamento expresso aos meios de obtenção de provas. Pelo menos existe esta confusão na doutrina. Fato é que não há uma distinção legal entre meios de prova e meios de investigação da prova ou outros procedimentos probatórios. Isto se deve, principalmente, porque o CPP é produto legislativo do ano de 1941, em que houve, tão somente, referência às provas padrão de um processo formal. Assim, vários aspectos pertinentes à obtenção da prova não estão referidos no CPP. Com efeito, o Código de Processo Penal Brasileiro, de 1941, no seu título VII versa sobre a prova e traz os seguintes capítulos, após as disposições gerais sobre a prova: do Exame do Corpo de Delito, e das Perícias em Geral (Capítulo II); do Interrogatório do Acusado (Capítulo III); da Confissão (Capítulo IV); do Ofendido (Capítulo V - alterado pela Lei 11.690/08); das Testemunhas (Capítulo VI); do Reconhecimento de Pessoas e Coisas (Capítulo VII);da Acareação (Capítulo VIII); dos Documentos (Capítulo IX); dos Indícios (Capítulo X); da Busca e da Apreensão (Capítulo XI). Por causa desta disposição a doutrina, de forma quase unânime, tradicionalmente cataloga os meios ali previstos como meios de prova. No entanto, a questão não parece tão simples como aparenta. Parte da doutrina sustenta, por exemplo, que o interrogatório do acusado, embora previsto no título de prova, em face da previsão constitucional do direito ao silêncio e de que o réu não deve produzir provas contra si mesmo, constitui, na verdade, meio de defesa (ver Antonio Gomes Magalhães Filho, Antonio Scarance Fernandes, Ada Pellegrini Grinover, dentre outros). Mas, há ainda quem sustente tratar-se de meio de prova ou instituto misto, meio de prova e de defesa (ver José Frederico Marques, Nucci, Mirabete, dentre outros). Já a confissão, também arrolada como meio de prova em quase sua unanimidade, recebe questionamentos no sentido de ser considerado o resultado de uma declaração de vontade que deve ser formalizada, podendo ser realizada dentro ou fora do processo. Defende-se, portanto, não ser um meio de prova, mas o resultado eventual do interrogatório, enquanto o meio de prova, neste caso, será o próprio interrogatório. Na mesma esteira o indício, que segundo José Carlos Barbosa Moreira, também não é, em si, um meio de prova, mas um fato provado, que permite, por um raciocínio indutivo-dedutivo, concluir pela existência de outro fato, sendo apenas o ponto de partida. Já a busca e apreensão é indubitavelmente uma medida cautelar de investigação da prova, embora, consoante exposto, não haja nenhuma distinção no CPP entre os meios de prova e os meios de obtenção de prova, catalogando-a como meio de investigação que de fato representa. Assim, depois de tratar dos 
certos procedimentos, em geral extraprocessuais, regulados pela lei, com o objetivo de conseguir provas materiais, e que podem ser realizados por outros funcionários (por exemplo, por policiais $)^{84}$, . Com o avanço da criminalidade assumiu maior relevância a obtenção de prova por diversos meios, com regras próprias. Nesse particular é de se salientar os meios telefônicos, os registros bancários e fiscais e a infiltração de agentes.

\section{Vale ressaltar que o projeto do Código de Processo Penal brasileiro} (2009), em tramitação, altera o capítulo de $\operatorname{provas}^{85}$, distinguindo os meios de provas dos meios de obtenção da prova ${ }^{86}$, adaptando o diploma a outros códigos como o de Portugal ${ }^{87}$ e o

meios de prova (perícias, testemunhos e documentos), o atual Código de Processo Penal disciplina o procedimento da busca e apreensão, que não visa obter elementos de prova, mas fontes de prova, como ocorre, também, com as interceptações telefônicas, a infiltração de agentes, bem como a captação e interceptação ambiental de sinais eletromagnéticos, óticos e acústicos. Estes são só alguns exemplos que demonstram a falta de disciplina de forma sistemática entre os meios de prova e de investigação. Além do mais, o rol constante no título de prova não é taxativo, havendo normas esparsas no CPP, como a reprodução simulada de fatos, providência destinada a obter elementos de prova, assim como a busca e apreensão, típica medida cautelar de obtenção de prova. Na Argentina critica-se a classificação da busca, da apreensão, do sequestro como meios de provas, uma vez que seriam medidas assecuratórias ou conservativas para obtenção de provas.

${ }^{84}$ FILHO, Antonio Magalhães Gomes. Op. Cit. p. 309.

${ }^{85}$ Com efeito, o Projeto que altera o Código de Processo Penal Brasileiro, de 1941, no seu título VIII versa sobre a prova e após as disposições gerais o capítulo II elenca nas seções subsequentes os meios de prova: Capítulo II Dos Meios de Prova; Seção I - Da Prova Testemunhal (art. 166 a art. 186); Seção II - Das Declarações da Vítima (art. 187); Seção III - Disposições Especiais Relativas à Inquirição de Crianças e Adolescentes (art. 188 a art. 190); Seção IV - Do Reconhecimento de Pessoas e Coisas e da Acareação (art. 191 a art. 195); Seção V - Da Prova Pericial e do Exame do Corpo de Delito (art. 196 a art. 210); Seção VI - Da Prova Documental (art. 211 a art. 216); E, no Capítulo III - Dos Meios de Obtenção da Prova; Seção I - Da Busca e da Apreensão (art. 217 a art. 228); Seção II - Do Acesso a Informações Sigilosas (art. 229 a art. 232); Seção III - Da Interceptação das Comunicações Telefônicas (art. 233 a 251).

${ }^{86}$ A doutrina brasileira, em certas ocasiões, utiliza a expressão meio de investigação (ou de pesquisa) como sinônimo de meio de obtenção de prova. Exemplo desse tratamento, de se citar Antonio Scarance Fernandes, quando ensina que: "os meios de investigação ou meios de obtenção da prova servem para descobrir e recolher uma fonte de prova, que será introduzida no processo mediante um meio de prova"; ou, ainda: "Por meios de investigação ou de obtenção de prova (buscas domiciliares, quebras de sigilo, interceptações telefônicas) descobrem-se e recolhem-se as fontes de prova (sangue do suspeito, registros bancários, diálogos feitos pelo investigado), sendo os resultados dessas diligências materializados em documentos (autos, termos, degravações, extratos bancários), os quais, muitas vezes, são submetidos a perícias (contábeis, de verificação de identidade com exames de DNA) ou reconhecimentos (objeto apreendido, cadáver)", In: Prova e sucedâneos da Prova no processo penal. Op. cit. p. 227 e p. 233 . Tal tratamento igualitário foi seguido neste trabalho, muito embora seja possível sustentar que exista uma sutil diferenciação porque o meio de investigação é que leva à desejada obtenção de prova. Significa dizer a ação é a investigação e o resultado é a obtenção da prova decorrente da investigação feita. Todavia, o meio de investigação quando empregado sem sucesso acaba por não obter a prova que se pretendia encontrar. Na Itália (notadamente seu Código de Processo Penal) e em outros países como a Espanha utiliza-se a expressão meio de investigação ou de pesquisa ao invés de meio de obtenção de prova. Esta é a conceituação também seguida por Antonio Magalhães Gomes Filho. De se apontar que o Projeto do Código de Processo Penal, em tramitação, optou pela expressão meios de obtenção de prova e não meios de investigação. Repisa-se que neste trabalho foram adotadas as expressões meio de investigação como sinônimo de meio de obtenção de prova. 
da Itália ${ }^{88}$, nos quais existe uma clara divisão entre meios de prova e meios de busca da prova $^{89}$ (mezzi di ricerca della prova, na terminologia do CPP italiano).

\author{
Os meios de investigação ${ }^{90-91}$ têm por escopo descobrir ou alcançar uma
} fonte de prova, constituindo, normalmente, providências de natureza cautelar ${ }^{92}$.

${ }^{87}$ O Código Português, ao tratar separadamente dos meios de obtenção de provas (distinguindo-os dos meios de produção de prova), arrolou os seguintes: os exames, as revistas e buscas, as apreensões, as escutas telefônicas e as ações encobertas (FERNANDES, Antonio Scarance. Revista Brasileira de Ciências Criminais, $n^{\circ}$ 66, maiojunho de 2007. Editora Revista dos tribunais - IBCCRIM, pág. 210).

${ }^{88}$ O Código de Processo Penal Italiano de 1988 disciplinou, em títulos diferentes, os meios de prova (mezzi di prova): testemunhos, perícias, documentos, que se caracterizam por oferecer ao juiz resultados probatórios diretamente utilizáveis na decisão e os meios de pesquisa de prova (mezzi di ricerca della prova): inspeções, buscas e apreensões, interceptações de conversas telefônicas, etc., que não são por si fontes de conhecimento, mas servem para adquirir coisas materiais, traços ou declarações dotadas de força probatória, e que também podem ter como destinatários a polícia judiciária ou o Ministério Público (Cf. FILHO, Antonio Magalhães Gomes, Notas sobre a terminologia da prova (reflexos no processo penal brasileiro) in Estudos em homenagem à Professora Ada Pellegrini Grinover, São Paulo, DPJ, 2005, pp. 303-318). O Código de Processo Penal português também faz distinção entre os meios de prova, disciplinados no título II do livro III, e os meios de obtenção de prova, tratados no título III, do livro III, arrolando como meios de obtenção de prova: a) exames (pessoas, coisas e lugares); b) revistas e buscas; c) apreensões; d) escutas telefônicas; e) ações encobertas.

${ }^{89}$ Neste diapasão a lição de Ada Pellegrini Grinover: "Não há como se confundir os meios de prova com os denominados meios de busca de prova. De fato, enquanto os primeiros constituem os instrumentos (documentos, depoimentos de testemunhas, exames periciais etc) que levam ao conhecimento dos sujeitos processuais os fatos, os segundos são as próprias medidas tendentes à busca, à coleta, à obtenção de provas (busca e apreensão, interceptação telefônica, quebras de sigilo bancário e fiscal e inspeções judiciais) as quais serão, posteriormente, instrumentalizadas e transportadas até o processo para conhecimento e apreciação de todos. (GRINOVER, Ada Pellegrini. Liberdades Públicas e processo penal: as interceptações telefônicas. $2^{\mathrm{a}}$ edição. São Paulo: RT, 1982. p. 201-203).

${ }^{90}$ Para Delfine Siracusano os mezzi di ricerca della prova, que podem ser utilizados pelo Ministério Público durante a indagine preliminare, "sono l'indispensabile tramite per l'acquisizione della prova", que "non sono di per sé fonte di convincimento, ma rendono possibile acquisire cose materiali, tracce o dichiarazioni dotate di attitudine probatoria". (SIRACUSANO, Delfine. Prova - Nel nuovo Codice di Procedura Penale. Enciclopedia Giuridica Treccani, Roma, 1991. vol. XXV, p.1).

${ }^{91}$ De se observar que Antonio Magalhães Gomes Filho utiliza a terminologia meios de pesquisa como sinônimo de meios de investigação.

${ }^{92}$ No relatório para as XX Jornadas Ibero Americanas de Direito Processual Penal em Málaga, na Espanha, no ano de 2006, com a participação de autores brasileiros (dentre eles Antonio Magalhães Gomes Filho, Gustavo Badaró, Antonio Scarance Fernandes), discutiu-se o tema de provas e ficou consignado que: "O campo dos meios de pesquisa ou de obtenção de prova é amplo, podendo-se, grosso modo, englobá-los em quatro grupos: a) os exames, as vistorias, as revistas; b) as buscas, apreensões, os sequestros; c) as interceptações, as escutas; as quebras de sigilo; d) as ações encobertas, a infiltração policial. Esses meios de obtenção de prova distinguem-se dos meios de produção de prova e constituem normalmente providência de natureza cautelar. Critica-se, na Argentina, a classificação como meios de prova de atividades como a revista, a busca, a apreensão, o sequestro, pois seriam medidas assecuratórias ou conservativas. Também no Brasil, afirma-se que a busca e apreensão não é meio de prova, mas uma medida cautelar (conforme Camargo Aranha), e se ressalta que a interceptação telefônica é medida cautelar (como Ada Pellegrini Grinover, Antonio Magalhães Homes Filho, Antonio Scarance Fernandes, Vicente Greco Filho, Luiz Flávio Gomes, Luiz Francisco Torquato Avolio) (FERNANDES, Antonio Scarance. Prova e Sucedâneos da Prova no Processo Penal (Extraído do Relatório para as XX Jornadas Ibero americanas de Direito Processual Penal em Málaga, Espanha em 2006 e publicado na Revista Brasileira de Ciências Criminais. Editora Revista dos Tribunais, nº 66, maio/junho de 2007). 
Assim, no que tange à essência e ao resultado imediato, os meios de investigação não consistem, de per si, em fontes de convencimento do magistrado, sendo unicamente instrumentos de aquisição de coisas materiais, vestígios ou documentos dotados de aptidão probatória. Servem, portanto, à prova, e não diretamente ao juízo ${ }^{93}$. Devem o uso e a avaliação destes meios de busca de prova ser feitos com cautela, tendo em conta que, em regra, são capazes de afrontar os direitos fundamentais, só podendo, assim, ser utilizados em casos extremos, devidamente justificados ${ }^{94}$.

Possível traçar algumas diferenças entre meios de prova e meios de investigação da prova. No que concerne ao dado probatório trazido ao juízo, os meios de prova têm caráter endoprocessual, ou seja, sua execução ocorre dentro do processo, formandose tão somente com a concretização de sua produção, por exemplo, nas informações resultantes da produção da prova testemunhal. Por outro lado, os meios de investigação da prova visam ao recolhimento de provas fora do processo para depois ser introduzida ao processo, por meio de um meio de prova. Significa dizer que o elemento probatório sempre preexiste ao procedimento de sua aquisição para o processo, consistindo em uma coisa pertinente ao delito, ou em informações contidas em um documento.

Além disso, os meios de prova oferecem resultados probatórios que podem ser utilizados diretamente pelo juiz na decisão. Isto porque, como os meios de prova devem produzir-se durante o processo e sempre perante o magistrado que preside a instrução ou o procedimento probatório, com a participação das partes, acaba por servir, desta forma, ao

\footnotetext{
${ }^{93}$ Delfino Siracusano coloca: "I mezzi di ricerca della prova sono gli strumenti di cui serve láutorità giudiziaria per individuare ed assicurare al processo cose, tracce, documenti Ed ogni altro elemento utile per provare i fatti che si riferiscono all'imputazione, A la punibilità ed a la determinazione della pena. Sono strumenti indispensabile per la ricerca probatória, ma nin sono di pré sè strumenti di convincimento. Servono a la prova man al giudizio" (SIRACUSANO, Delfino. Diritto processuale penale, vol. I, Milano, Giuffrè, 1994, p. 427).

${ }^{94}$ No relatório para as XX Jornadas Ibero Americanas de Direito Processual Penal em Málaga, na Espanha, no ano de 2006, merece registro a preferência do relator argentino (Pedro J. Bertolino), com base na doutrina de seu país, pelas expressões meios de prova ordinários e meios de prova extraordinários. Conforme esclarece, os meios extraordinários são aqueles que apresentam especiais peculiaridades: dificuldades maiores na sua efetivação e sérios problemas para a observância das garantias fundamentais. A utilização desses meios representa grave risco de se legitimar a ilegalidade na averiguação penal. Decorrem, por exemplo, de ações realizadas pelo "agente encoberto", "o informante", "o arrependido", o "testemunho de identidade protegida" (FERNANDES, Antonio Scarance. Prova e Sucedâneos da Prova no Processo Penal (Extraído do Relatório para as XX Jornadas Ibero americanas de Direito Processual Penal em Málaga, Espanha em 2006 e publicado na Revista Brasileira de Ciências Criminais. Editora Revista dos Tribunais, nº 66, maio/junho de 2007).
} 
processo e principalmente ao convencimento do juiz. Já os meios de investigação da prova consistem em fontes indiretas de aquisição de material probatório e dentro dos limites definidos em lei, podem ter como destinatários o magistrado, o Ministério Público ${ }^{95}$, ou até a Polícia Judiciária, em hipóteses mais restritas ${ }^{96}$.

Paolo Tonini ${ }^{97}$ ressalta outra importante distinção residente no fator surpresa que geralmente acompanha a realização dos procedimentos de investigação, sem o qual seria inócua a obtenção das fontes de prova. Por seu turno, nos meios de prova, tendo em vista a rigorosa obediência ao contraditório ${ }^{98}$, supõe tanto o conhecimento como a efetiva participação das partes na sua realização ${ }^{99}$.

Assim, os meios de investigação da prova, levados a cabo, normalmente, ainda na fase preliminar da persecução penal, têm como traço fundamental o elemento surpresa, para que possam prestar-se à sua finalidade assecuratória. Deste modo, não há que se falar em prévia intimação do defensor do investigado, quando são realizados na fase de investigação.

Por fim, possível citar, ainda, mais uma diferença entre os meios de prova e os meios de obtenção ou investigação da prova, no tocante às possíveis repercussões das irregularidades verificadas em cada caso ${ }^{100}$.

${ }^{95}$ COMOGLIO, Luigi Paolo. Lessico delle prove e modello accusatorio. Rivista de dirritto processualle. 1995, 50 (4): 1206-7.

${ }^{96}$ Paolo Comoglio afirma que os meios de pesquisa da prova: "não são por si só fontes de convencimento, mas servem, tais instrumentos, para adquirir "coisas materiais, trazendo declarações dotadas de atitudes probatórias" e então tem como possíveis destinatários também o Ministério Público e a polícia judiciária, nos limites previstos pelo Código". Op. Cit, p. 126.

97 TONINI, Paolo. A Prova no processo penal italiano, trad. Alexandra Martins e Daniela Mróz, São Paulo, Revista dos Tribunais, 2002, p. 242-243.

${ }^{98}$ Com relação ao contraditório na matéria de provas consultar texto de Giulio Ubertis em que o autor analisa o papel do contraditório na formação da prova penal: "In questa prospetiva epistemologica, chi sostiene Il valore del contradditorio non intende rinunciare a la ricerca della cerità giudiziale, ma anzi affermare che quest'ultima si persegue meglio com la dialettica tra le parti Che com la ricerca solipsistica dell'inquisitore" (UBERTIS, Giulio. Il contradittorio nella formazione della prova penale, in Estudos em Homenagem à Professora Ada Pellegrini Grinover. Flavio Luiz Yarshell e Maurício Zanoide de Moraes (orgs.), cit. , p. 332).

${ }^{99}$ FILHO, Antonio Magalhães Gomes. Op. Cit. p. 309.

${ }^{100}$ Com relação à repercussão processual da prova obtida por meio ilícito, Antonio Scarance Fernandes leciona que: "A prova obtida por meio ilícito não pode ser admitida no processo (art. $5^{\circ}, \mathrm{LVI}$ ), sendo destituída de eficácia jurídica". O Supremo Tribunal Federal, em precisa manifestação do Ministro Celso de Melo (STF, RE 251.445-GO, Informativo 197), bem acentuou que a "cláusula constitucional do due processo of law encontra, no 
No caso dos meios de prova a consequência do vício será a nulidade da prova produzida, enquanto que para os meios de obtenção de prova ocasionará a inadmissibilidade no processo $^{101}$, diante da violação das regras relacionadas à sua obtenção. É a chamada inadmissibilidade da prova obtida por meios ilícitos ${ }^{102}$, prevista expressamente no artigo $5^{\circ}$, inciso LVI, da Constituição Federal, cuja ilicitude leva a que a prova não possa ser introduzida no processo e se introduzida não seja levada em conta no julgamento ou até mesmo desentranhada ${ }^{103}$, para que não corra risco de contaminar a formação do convencimento $^{104}$.

dogma da inadmissibilidade processual das provas ilícitas, uma de suas mais expressivas projeções concretizadoras, pois o réu tem direito de não ser denunciado, de não ser processado e de não ser condenado com apoio em elementos probatórios obtidos ou produzidos de forma incompatível com os limites ético-jurídicos que restringem a atuação do Estado em sede de persecução penal. A prova ilícita - por qualificar-se como elemento inidôneo de informação - é repelida pelo ordenamento constitucional, apresentando-se destituída de qualquer grau de eficácia jurídica”. (Processo Penal Constitucional. São Paulo: RT, 2003, p. 90).

${ }_{101}$ Mais significativa, no sentido da inadmissibilidade da prova ilícita, foi a posição adotada pelo Supremo Tribunal Federal em três julgamentos em que foi suscitada a validade de interceptações telefônicas clandestinas: no primeiro, de 1977, foi determinado o desentranhamento de fitas gravadas, correspondentes a interceptação de conversa telefônica da mulher, feita pelo marido, para instruir processo de separação judicial; num segundo caso, em 1984, também de processo cível, a solução foi a mesma; e, finalmente, em decisão de 18-12-1886, a Suprema Corte determinou o trancamento de inquérito policial baseado em interceptações confessadamente ilícitas feitas por particulares.

${ }_{102}$ Neste ponto, oportuno mencionar a distinção entre provas ilícitas e ilegítimas: as primeiras seriam obtidas em violação a direito material, ao passo que as segundas seriam produzidas em desacordo com regra processual. Antonio Magalhães Gomes Filho destaca ainda outras diferenças entre as provas ilícitas e as ilegítimas: naquelas a ilegalidade ocorre quando de sua obtenção, ao passo que nestas, a violação ocorre no momento de sua produção. Além disso, destaca o autor que as consequências geradas por ambas são diversas: as provas ilícitas são "inadmissíveis no processo (não podem ingressar e, se isso ocorrer, devem ser desentranhadas); as ilegítimas são nulas e, por isso, a sua produção pode ser renovada, atendendo-se então às regras processuais pertinentes". Vale ressaltar, ainda, que o autor não elogia a forma como o legislador tratou o tema da inadmissibilidade das provas obtidas por meios ilícitos, na reforma do CPP, com o advento da Lei 11.690/2008. Isto porque, na visão de Magalhães não era necessária a regulamentação do art. $5^{\circ}$, LVI, da Constituição Federal pelo legislador infraconstitucional, especialmente diante de certos equívocos e imprecisões do legislador. (FILHO, Antonio Magalhães Gomes. Provas in As reformas no processo penal: as novas Leis de 2008 e os projetos de reforma, coord. Maria Thereza Rocha de Assis Moura, São Paulo, Revista dos Tribunais, 2008, pp. 265-266).

${ }^{103}$ Depois de muita discussão, tanto na doutrina como na jurisprudência, sobre o que fazer com a prova obtida por meio ilícito, a reforma do CPP, cuja redação foi dada pela Lei $n^{\circ} 11.690 / 2008$, ao menos no texto jurídico, terminou com a controvérsia, já que o artigo 157 trouxe a solução a ser adotada: Art. 157 - São inadmissíveis, devendo ser desentranhadas do processo, as provas ilícitas, assim entendidas as obtidas em violação a normas constitucionais ou legais. Até então, os tribunais davam efetiva aplicação à sanção da inadmissibilidade de formas variadas: a) não permitindo o ingresso da prova ilícita no processo, como no julgamento da Correição Parcial 92/90, TRF $3^{a}$ Região, em que foi indeferida a correição parcial requerida pelo MP contra ato do Juiz da $12^{a}$ Vara Federal, inadmitindo a transcrição e juntada aos autos do resultado de gravações clandestinas; b) determinando seu desentranhamento, como no MS 590.019.089, do TJ Rio Grande do Sul, em que a $5^{\text {a }}$ Câmara Cível concedeu a ordem para o desentranhamento, do processo, do resultado de gravações feitas sem o consentimento das pessoas participantes da conversa; c) ou ainda desconsiderando a prova no momento da valoração e, em consequência, absolvendo o réu contra o qual a prova havia sido produzida, conforme ocorrido no julgamento da apelação criminal 82.624/3 pelo TJ São Paulo, da relatoria de Dante Busana, cujo caso tratava de prova da materialidade resultante de busca e apreensão realizada sem mandado judicial, com invasão de 


\title{
1.5 Necessidade de adoção de novos meios (técnicas) de investigação repressivos à criminalidade organizada moderna
}

\begin{abstract}
Diante do avanço da criminalidade e da insuficiência dos meios atuais de investigação (e até para atingir a eficiência desejada de um Estado atuante), impossível não se admitir a adoção de novas técnicas ${ }^{105}$ tão avançadas quanto os instrumentos utilizados pelas organizações criminosas $^{106}$, objetivando um enfrentamento paritário. Porém, estes novos e possíveis meios de investigação, para obtenção de provas essenciais que levem à penalização
\end{abstract}

domicílio e, reconhecendo a ilicitude da prova, a Câmara criminal absolveu o réu por falta de prova do fato imputado.

${ }^{104}$ José Roberto Bedaque dos Santos tem posição mais flexível que a maioria da doutrina, porque no seu entender: "não se pode concordar com a absoluta desconsideração das provas ilícitas (...), pois a repulsa a tal prova, como regra genérica, em nada beneficia o ordenamento jurídico, já violado pelo ato ilegal que a obteve. E, com a rejeição de uma prova obtida irregularmente, poderá o julgador ficar sem elementos suficientes para proferir uma decisão justa". (SANTOS, José Roberto Bedaque dos. Poderes Instrutórios do Juiz. $2^{a}$ ed. São Paulo: RT, 1996. p. 103-105).

${ }^{105}$ Para Fausto Martin de Sanctis as técnicas especiais de investigação visam ao combate efetivo do crime organizado para viabilizar processamento e julgamento eficaz, célere (no tempo adequado e correspondente às necessidades) e abrangente das condutas então investigadas. Lembra, ainda, que "o Grupo de Ação Financeira Internacional em Lavagem de Dinheiro (Groupe d'action Financière sur le Blanchiment de Capitaux ou Financial Action Task Force on Money Laundering - GAFI/FATF) recomenda a utilização, pelas autoridades de aplicação específica, das técnicas especiais de investigação (Recomendação n. 27), devidamente grifada: "Os países deveriam assegurar que as investigações sobre a lavagem de capitais e o financiamento do terrorismo são confiadas a autoridades de aplicação da lei específica. Os países são encorajados a apoiar e a desenvolver, tanto quanto possível, técnicas especiais de investigação adequadas à investigação da lavagem de capitais, tais como as entregas controladas, as operações encobertas e outras técnicas pertinentes. Os países são também encorajados a usar outros mecanismos eficazes, tais como o recurso a grupos permanentes ou temporários especializados em investigações sobre o patrimônio e em investigações realizadas em colaboração com as correspondentes autoridades competentes de outros países. A razão de ser, como se pode observar, certamente foi a percepção de que a prática delituosa evoluiu para a adoção de complexos comportamentos visando ludibriar a administração da Justiça, numa atividade marginal, porém, indispensável, sendo certo que as questões fáticas acabaram por colocar em cheque métodos ortodoxos de investigação" (DE SANCTIS, Fausto Martin. Op.cit. p. 10).

${ }^{106}$ Para Mendroni: "O estreito vínculo estabelecido entre o Direito e a Informática tem suscitado uma série de situações que levam estudiosos do Direito a deparar-se com circunstâncias inusitadas que requerem estudos inovadores, representando verdadeiro desafio aos profissionais da área. É preciso formar uma estrutura material compatível com o combate à organização criminosa, mas atualmente com ênfase aos computadores e softwares. Existem softwares a cada dia mais avançados como, por exemplo, para a execução de interceptações telefônicas. São computadores ligados ao telefone que armazenam em CD-ROMS toda a informação, que já emitem relatórios em relação a datas, números de telefones com conexões e que fazem para nós um trabalho muito eficiente. Existem também softwares que, fazem a ligação entre as quadrilhas, com endereços, nomes, apelidos, valores, territórios. Isto tudo auxilia sobremaneira, a entender o formato da organização criminosa. $\mathrm{O}$ material de informática é, portanto, o mais importante, pois a investigação deve ser priorizada no seu âmbito de checagem, análise e cruzamento das informações. Não se pode prescindir também da utilização de recursos das microcâmeras e escutas ambientais, entre outros. Essencial é evoluir bastante nesse aspecto tecnológico, até porque a evolução do expediente probatório nos mostra claramente que, a cada passo da evolução, vamos cada vez mais utilizar sistemas tecnológicos em produção de prova e menos prova testemunhal" (MENDRONI, Marcelo Batlouni. Crime Organizado. São Paulo: Editora Atlas, 2007, p. 23). 
das organizações criminosas, devem se pautar pela estrita observância das regras e procedimentos legais, tudo dentro do devido processo legal.

Muito se questiona se a criminalidade organizada pode (ou deve) ser combatida no âmbito processual da mesma forma que a criminalidade comum ${ }^{107}$. A resposta a tal indagação tem indicado ser inevitável a constatação de que o enfoque tradicional $^{108}$ dado aos meios de atuação vem se mostrando insuficiente ${ }^{109}$ na persecução da delinquência organizada pós-moderna.

Embora a política criminal, consoante exposto outrora, não se deva pautar unicamente no aspecto repressivo, certo é que a criminalidade organizada justifica um tratamento diferenciado para seu enfrentamento. O que não significa adoção de medidas mais duras sem o devido planejamento e observâncias das garantias do acusado, ainda que de forma mitigada.

Diante do panorama que se apresenta e em face da afirmação de que os métodos convencionais de investigação são insatisfatórios para combater o crime organizado, torna-se absolutamente necessária a busca e a estruturação de novas técnicas investigatórias ${ }^{110}$,

\footnotetext{
${ }^{107}$ Quanto a tal questão ver Eduardo Araujo da Silva. Crime organizado. Procedimento probatório. Op. cit. p. 40 e seguintes. No âmbito do direito italiano, vide: Ottavio Sferlazza. Processo Acusatorio oral y delincuencia organizada. México: Fontamara, 2006.

108 Adverte Mario Daniel Montoya: "Não é possível desenvolver uma atividade adequada de prevenção e investigação com uma força policial reduzida em membros, organização e meios, que carece do apoio da população, imersa em um contexto conflituoso, cujas funções de comando e de responsabilidade estão excessivamente fracionadas e diluídas, expostas à corrupção, que não conta com os métodos mais modernos de comunicação e de obtenção de informação em tempo real, escassamente profissionalizada, com poucas possibilidades de recorrer a conhecimentos especializados em setores pouco usuais de competência, não coordenada e em permanente concorrência com outras agências de investigação" (MONTOYA, Mario Daniel. Máfia e crime organizado. Op.cit. p.78.).

${ }^{109}$ Adverte Lorenzo M. bujosa Vadell que: “Atualmente o problema mais crítico talvez se encontre na magnitude das complexas ramificações das organizações criminais e nas dificuldades para a persecução dessas atividades ilícitas que nos dias atuais se beneficiam das limitações dos nossos ordenamentos jurídicos tradicionais e, sobretudo, das dificuldades na coordenação de uma resposta global e necessariamente cooperativa na persecução penal por parte dos Estados" (VADELL, Lorenzo M. Bujosa. La prueba testimonial ante la delincuencia organizada. México: Porrua, 2006, p. XXI).

110 Valiosa a observação de Mariângela Lopes quando analisa este cenário: "Novas formas de cometimento de delitos, de que se vale a criminalidade moderna, alcançam, não raro, o coração político do Estado. Este novo viés da criminalidade organizada é bastante avançado. Utilizam-se, como meios de atuação, formas modernas que dificultam a produção e a descoberta das provas. Diante disso, necessário se faz a busca de novas formas de investigação na persecução dos agentes concretizadores da citada criminalidade, que desafia a atuação estatal.
} 
adequadas à realidade e aptas a surtirem efeitos no âmbito da persecução criminal, marcada pela busca do alto grau de eficiência e pela mantença das garantias e dos direitos fundamentais daquelas pessoas submetidas ao processo penal ${ }^{111}$.

Por isso, com o crescimento e desenvolvimento da criminalidade organizada, especialmente relacionada ao tráfico de entorpecentes ou drogas ilícitas, que se utiliza de meios extremamente modernos para atingir as suas finalidades, surgiu uma preocupação mundial em criar novos meios de investigação ${ }^{112}$, algumas vezes excepcionais, que pudessem auxiliar os Estados na busca e obtenção de provas dos crimes praticados por essas organizações ${ }^{113}$, que muitas vezes não deixam rastros de sua atuação ou possuem formas de destruí-las ${ }^{114}$ ou simulá-las ${ }^{115}$ por meio de técnicas de lavagem de dinheiro ou com ajuda de

Não é de hoje que a comunidade jurídica ocupa-se com o crescimento constante da criminalidade, criando novas formas de combate para enfrentá-la. A busca de meios mais eficazes para reprimir comportamentos delituosos tem se tornado incessante" (tese de mestrado USP: "O agente infiltrado como meio de investigação", 2006).

${ }^{111}$ Ver: Flávio Cardoso Pereira. A moderna investigação criminal. In: Limites ...Op. cit. p. 112.

112 Oportuna a lição de Antonio Scarance Fernandes, quando analisa o crime organizado e a prova: "É essencial para a sobrevivência da organização criminosa que ela impeça a descoberta dos crimes que pratica e dos membros que a compõem, principalmente dos seus líderes. Por isso ela atua de modo a evitar o encontro de fontes de prova de seus crimes: faz com que desapareçam os instrumentos utilizados para cometê-los e com que prevaleça a lei do silêncio entre os seus componentes; intimida testemunhas; rastreia por meio de tecnologias avançadas os locais onde se reúne para evitar interceptações ambientais; usa telefones e celulares de modo a dificultar a interceptação, preferindo conversar por meio de dialetos ou línguas menos conhecidas. Por isso, os Estados viram-se na contingência de criar formas especiais de descobrir as fontes de provas, de conservá-las e de permitir produção diferenciada da prova para proteger vítimas, testemunhas e colaboradores". (Repressão Penal e Crime Organizado. Os novos Rumos da Política criminal após o 11 de setembro. In: O equilíbrio entre a eficiência e o garantismo e o crime organizado. São Paulo: Ed. Quartier Latin, 2009, p.241).

${ }_{113}$ Kaiser reitera este ponto ao escrever: "Justifica-se, ainda, a busca a outros meios extraordinários de investigação criminal, diante da constatação de que hodiernamente, visualiza-se um processo penal que se encontra de costas aos avanços científicos do último século e que, com seu atraso, perde a oportunidade, frente às vantagens que os mesmos poderiam proporcionar para os sujeitos ativos do processo penal" (in: Organizaed crime”. Kongressakten XIV, Internationaler Strafrechtkongress. AIDP, 1989, p. 203/205.).

114 Além da complexidade e da variedade dos atos que compõem a criminalidade organizada, seus autores também se dedicam a impedir a obtenção da prova. Essa "cultura da supressão da prova", relata Elvio Fassoni (La valutazione della prova nei processi di criminalità organizzata. In: Processo Penale e criminalità organizzata, Vittorio Grevi (org.). Roma - Bari: Laterza, 1993, p. 229-230), pode ser notada nas atitudes dos criminosos contemporâneos: a arma disparada para matar alguém é destruída, para evitar comparações com outros episódios de fogo; o automóvel utilizado não é apenas roubado, mas incendiado, para não deixar vestígios; o assassino, proveniente de muito longe, é desconhecido no ambiente onde age; os suspeitos procuram álibis convincentes e agem por meio de terceiros; os telefonemas dos sequestradores não duram muito tempo para não permitir a identificação de sua origem; as fontes testemunhais, quando raramente existem, vêm intimidadas ou oprimidas; no interior do grupo criminoso as informações são rigorosamente restritas, para evitar os danos decorrentes de impossível dissociado no futuro. Neste sentido, Eduardo Araujo Silva citando Jean Ziegler constata que: "Ainda uma forma mais sofisticada de impedir a obtenção de prova vem sendo constatada pelas autoridades europeias: com o desenvolvimento nos últimos anos - tanto no plano legal, como no campo tecnológico - do emprego de técnicas de interceptação ambiental ou de vigilância eletrônica, os integrantes de algumas organizações criminosas passaram a adquirir equipamentos eletrônicos, geralmente com tecnologia 
agentes estatais que tem facilidade em eliminar tais evidências valendo-se muitas vezes de suas posições, criando subterfúgios possíveis de ocultação de provas que levam à impunidade de tais organizações. A figura da entrega vigiada adveio dessa necessidade de adequação ao desenvolvimento da requintada criminalidade.

Contudo, nesta desenfreada - e diga-se muitas vezes injusta - luta contra o crime organizado têm sido criados diversos meios de investigação ofensivos (ou, ao menos, perigosos) ao Estado Constitucional de Direito. A admissão destes novos meios investigatórios, mesmo quando extraordinários, devem ser capazes de produzir resultado útil contra o crime organizado e vir acompanhados de medidas que mitiguem seus efeitos negativos $^{116}$.

superior àqueles utilizados pela polícia, que facilmente identificam a presença de microfones ocultos ou microcâmeras instalados nos ambientes por eles frequentados (moradias, hotéis, escritórios etc.), comprometendo assim a obtenção da prova, pois as autoridades não dispõem de equipamentos de ponta que não possam ser detectados ou neutralizados. Outrossim, percebeu-se que os membros das organizações criminosas passaram a comunicar-se com frequência por meio de idiomas estrangeiros ou dialetos, o que dificultou ainda mais o trabalho da polícia, pois sequer dispõe de tradutor para certas línguas. Op. cit. p. 42.

${ }^{115}$ Neste sentido, Joaquín Delgado Martín: "Os meios tradicionais de averiguação do delito utilizados pela polícia (inspeções oculares, interrogatórios etc.) mostram-se absolutamente ineficazes na luta contra a expansão do fenômeno delitivo denominado "delinquência organizada". Tal constatação é obtida em razão de alguns fatores, dentre os quais, destaca-se a complexidade das organizações criminosas, que se utilizam de altíssimo grau de profissionalismo, já que são assessoradas por especialistas em matérias técnicas como a informática, a economia e o direito. Também, em razão da dificuldade na produção da prova testemunhal que comprove a realização de atos criminosos pela organização delitiva, vez que a cultura da supressão da prova impera juntamente com a afirmação de um código de silêncio extremamente rígido" (MARTín, Joaquín Delgado. Criminalidad Organizada, Barcelona: J.M. Bosch, 2001, p. 21).

${ }^{116}$ Dentre os autores espanhóis esta preocupação é constante. Contextualiza Joaquín Delgado Martín ( $L a$ criminalidad Organizada, Op. cit. p. 32.): "El Estado debe emplear, y viene utilizando de forma creciente, los nuevos métodos de investigación para combatir el crimen organizado. Ahora bien, muchos de ellos afectan seriamente a los derechos fundamentales de los ciudadanos, algunos de forma más intensa que los empleados tradicionalmente por los cuerpos de policía; y de otros desconocemos sus efectos reales". Continua Juan Muñoz Sánchez (La moderna problemática jurídico penal del agente. op. cit. p.23): "Se han destacado algunos riesgos generados por la guerra contra la criminalidad organizada, pero lo más grave es que todavía se ignoran los peligros reales derivados de la continuación en la tendencia a admitir instrumentos extraordinarios, tanto en extensión como en intensidad. En este ámbito, los mayores peligros derivan de la infiltración para el control de peligros potenciales en el campo previo a la lesión concreta de un bien jurídico. Desde esta perspectiva, los operados jurídicos deben estar especialmente alerta para detectar qué medios de combate son extraordinarios; y, partiendo de esa conciencia, realizar un esfuerzo para que su aplicación no se realice fuera del ámbito del crimen organizado". Por otra parte, únicamente deberán admitirse los medios exorbitantes contra el crimen organizado que realmente generen resultados útiles contra la delincuencia organizada, siempre y cuando estén acompañados de medidas que mitiguen sus efectos negativos, especialmente a través del efectivo control judicial; y siempre con el claro límite de la garantía de los derechos fundamentales constitucionalmente reconocidos. 


\section{Algumas destas novas técnicas de investigação estão previstas no}

regramento brasileiro, notadamente na Lei $n^{\circ}$ 9.034/95 com as alterações trazidas pela Lei $n^{\circ}$ 10.217/01. Referida norma, mesmo sem definir o conceito de organização criminosa, mencionou alguns métodos de investigação para a prevenção e repressão das ações praticadas por organizações ou associações criminosas, tais como: o agente infiltrado, o acesso a dados, documentos e informações fiscais, bancárias, financeiras e eleitorais (quebra de sigilo) ${ }^{117}$, a captação e interceptação ambiental de sinais ${ }^{118}$, o agente infiltrado ${ }^{119}$ e a ação controlada.

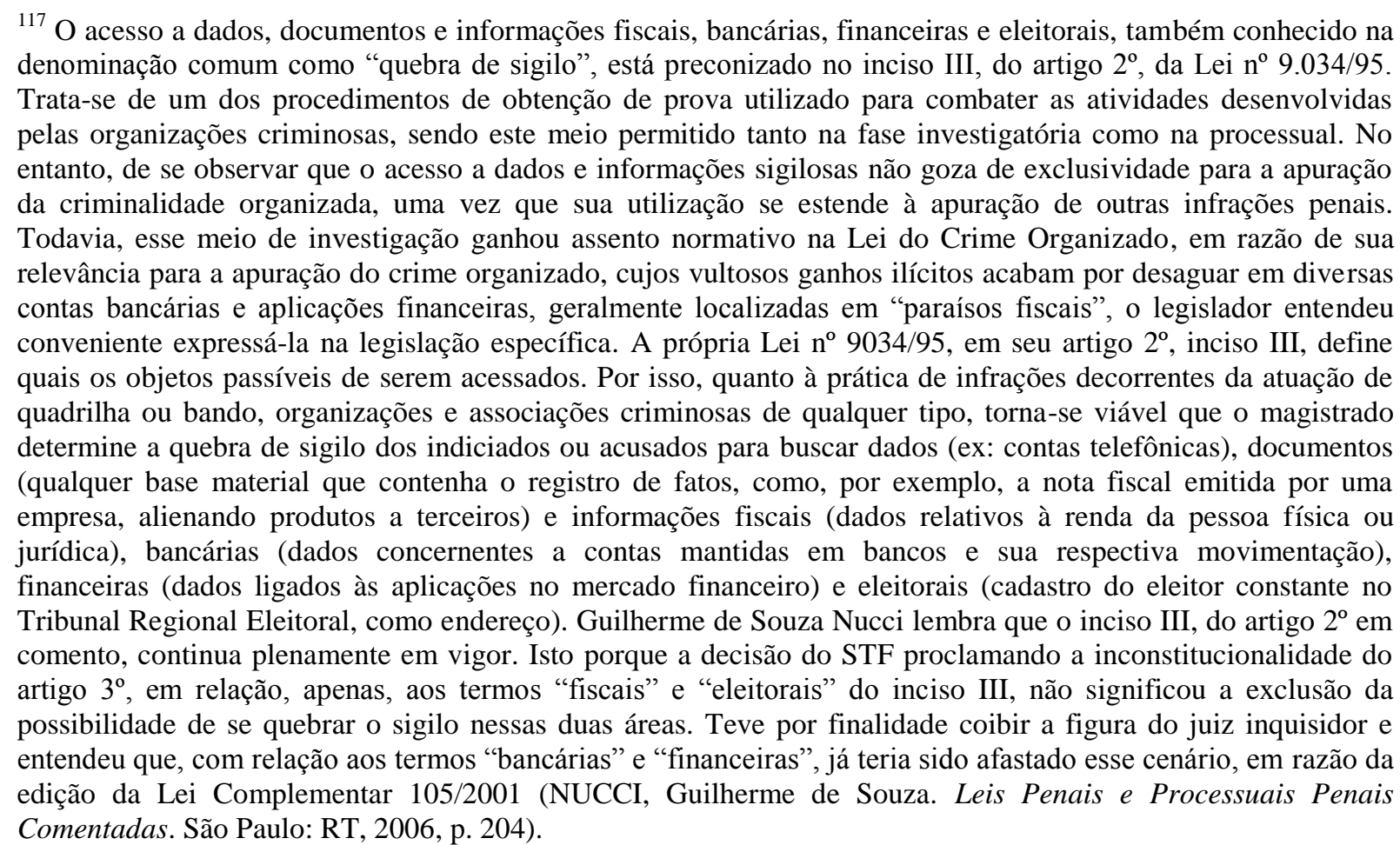

${ }^{118}$ A captação e interceptação ambiental de sinais eletromagnéticos, óticos ou acústicos, prevista no inciso IV, do artigo $2^{\circ}$, da Lei $\mathrm{n}^{\circ}$ 9.034/95 (introduzida pela Lei $\mathrm{n}^{\circ} 10.271 / 2001$ ), e também denominada de vigilância eletrônica, constitui procedimento excepcional de investigação e formação de prova, que pode ser autorizada para a fase investigatória como para a processual, e seu registro e análise deve ocorrer mediante circunstanciada autorização judicial. Segundo Ada Pellegrini Grinover, Antonio Scarance Fernandes e Antonio Magalhães Gomes Filho, entende-se por interceptação a "captação da conversa por um terceiro, sem o conhecimento de seus interlocutores, ou com o conhecimento de um só deles". Assim, na interceptação ambiental significa que o diálogo se desenvolve em recinto, a permitir o contato entre as pessoas que têm a conversa devassada por terceiro (GRINOVER, Ada Pellegrini; FERNANDES, Antonio Scarance; FILHO, Antonio Magalhães Gomes. As nulidades no processo penal, $8^{a}$ edição, São Paulo: RT, capítulo IX, seção VI, n.1, 2004). Para Nucci: "De maneira geral, as comunicações entre pessoas podem ocorrer de diversas formas, seja entre presentes, por carta, por telefone entre outras tantas possibilidades. Contudo, quando se utiliza o termo captação, significa dizer que há a colheita de determinados dados, feita por um interlocutor em relação ao outro. A denominação captação ambiental traduz, justamente, a situação em que a conversa ocorre em um recinto qualquer (não pelo telefone, nem por carta), possibilitando o contato pessoal entre os interlocutores, enquanto uma delas coleta, por qualquer meio (gravação de voz, registro de imagem fotográfica, filmagem), o que se passa entre ambos" (NUCCI, Guilherme de Souza. Op. Cit, p. 204). 


\section{Dentre estes meios investigatórios será examinada com maior detalhamento a ação controlada, tendo em vista sua semelhança com a entrega vigiada e a preocupação que será enfrentada oportunamente, de se distinguir os institutos.}

\subsubsection{Ação controlada}

119 A nova redação dada pela Lei no 10.217/01 trouxe a previsão da infiltração de agentes no combate às organizações criminosas, como procedimento de investigação e formação de prova - hipótese que também possui previsão na nova Lei de Drogas (Lei no 11.343/06). Ambas as legislações brasileiras (9.034/95 e 11.343/06) não disciplinam a infiltração de agentes a contento, havendo um vazio legislativo. Somente exigem autorização judicial, e, na Lei de Drogas, prévia oitiva do Ministério Público, e ser a medida realizada por agente policial. Caberá ao juiz especificar os limites da atuação do agente sem parâmetros legais. O agente infiltrado é membro de polícia ou de inteligência que, autorizado por um Juiz, em tarefas de investigação, constituída pelos órgãos especializados pertinentes, oculta sua identidade, e se insere, de forma estável, em determinada organização criminosa, na qual ganha confiança de seus membros, por ser aparentado a eles, tendo acesso a informações sigilosas, com a finalidade de comprovar eventual cometimento do delito, assegurar fontes de prova e identificar seus autores. Para Mariângela Lopes é possível chegar a uma definição comum de agente infiltrado, observando algumas características que lhe são inerentes: 1. Ser policial; 2. agir de forma disfarçada ocultando a identidade; 3. atuar com autorização judicial; 4. inserir-se de forma estável, e não esporádica, nas organizações criminosas; 5. fazer-se passar por criminoso para ganhar a confiança dos membros das organizações; 6. visar a descoberta de provas de crimes graves ("O agente infiltrado como meio de investigação". Dissertação de mestrado na USP, 2006). Na Espanha e em Portugal permite-se a infiltração de pessoa estranha aos quadros policiais, bastando que ela atue sob o controle estatal. A Argentina descarta a infiltração por intermédio de agentes particulares. Somente é permitida a infiltração de empregado ou funcionário público, isto é, um agente estatal, e mais especificamente, um agente de "fuerzas de seguridad". Joaquín Delgado apresenta interessante diferenciação para situações semelhantes que envolvem o mesmo tema de "agentes infiltrados". Distingue-os em quatro formas mais específicas: 1) “Agente meramente Encubierto": agente que investiga a prática de um delito mediante a técnica consistente em ocultar sua condição de policial, sem outras manobras ou instrumentos de infiltração. Normalmente, sua atuação se centraliza na investigação de um fato delituoso isolado, sem estender-se na atividade geral de uma organização criminosa e sem prolongar-se no tempo; frequentemente aborda os fatos delituosos cometidos por autores isolados, ou pertencentes a pequenas organizações criminosas; 2) "Agente Encubierto Infiltrado": a sofisticação inerente à atividade das organizações criminosas frequentemente exige que o agente não somente oculte a sua condição, mas também integre as suas estruturas e participe de suas atividades. O termo mais adequado para definir essa figura é de agente infiltrado, porque ele se introduz sub-repticiamente na organização criminosa; 3) "Agente Encubierto Infiltrado con Identidad Supuesta": para que o Agente Encoberto (AE) possa se infiltrar de forma adequada na organização criminosa, é necessário que se apresente ante os seus integrantes com identidade falsa. Deparamos, desta forma, com uma modalidade de Agente Encoberto infiltrado na qual ele assume dados que o identificam como outra pessoa diversa daquela que é realmente. A adoção de uma identidade falsa supõe um salto qualitativo nos distintos graus de infiltração policial, porque o próprio poder público utiliza mecanismos por si só delituosos para criar uma identidade falsa; 4) "Agente Provocador": esta figura surge quando um agente de polícia que oculta a sua condição provoca a prática de um delito, isto é, incita a praticar a infração a quem não tinha previamente tal propósito, originando assim o nascimento de uma vontade criminal no caso concreto, delito que não teria sido praticado sem dita provocação. Assim entendido, poderá ser agente provocador qualquer Policial que atue como agente encoberto, infiltrado ou não, com ou sem identidade falsa (DELGADO, Joaquín. Criminalidad Organizada. Barcelona: Bosch, 2001. p. 46-48). 


\begin{abstract}
A ação controlada ${ }^{120}$ é também comumente denominada pela doutrina como flagrante retardado ${ }^{121}$, diferido ou prorrogado ${ }^{122}$.
\end{abstract}

\author{
Pela definição legal trazida pelo artigo $2^{\circ}$, inciso II, da Lei do Crime \\ Organizado, a ação controlada consiste em retardar a interdição policial ${ }^{123}$ do que se supõe \\ ação praticada por organizações criminosas ou a ela vinculado ${ }^{124}$, desde que mantida sob
}

${ }^{120}$ A ação controlada consiste em a Polícia manter vigilância sobre a atividade criminosa, acompanhando-a até o momento mais adequado, ou seja, o mais eficaz do ponto de vista da formação de provas e fornecimento de informações (PRADO, Geraldo; DOUGLAS, Willians. Comentários à Lei Contra o Crime Organizado. Belo Horizonte: Del Rey, 1995, p.50).

${ }^{121}$ Para Nucci, ação controlada significa o retardamento da realização da prisão em flagrante, mesmo estando a autoridade policial diante da realização do crime praticado por organização criminosa, sob o fundamento de se aguardar o momento oportuno para tanto, colhendo-se mais provas e informações. Assim, quando futuramente, a prisão se concretizar, será possível atingir um maior número de envolvidos, especialmente, se viável, a liderança do crime organizado. Assim, o autor equipara a ação controlada ao flagrante diferido ou retardado (Op. Cit. p.203). Blanche Maymone Matos leciona que a "ação controlada tem como característica principal o retardamento da intervenção policial, apesar de o fato criminoso já se encontrar em uma situação de flagrância, permitindo a efetivação do chamado "flagrante prorrogado ou diferido"'. Prossegue a autora esclarecendo que, "no flagrante esperado, a intervenção da autoridade se dá num momento certo, sem nenhuma vigilância permanente; a situação de flagrante não é duradoura e a prisão tem que acontecer imediatamente" (GOMES, Rodrigo Carneiro. Op. cit. p. 205).

${ }^{122}$ Com relação a esta questão do flagrante, Eduardo Araujo da Silva expõe que: "a ação controlada por policiais, consiste em estratégia de investigação que possibilita aos agentes policiais retardarem suas intervenções em relação a infrações em curso, praticadas por organizações criminosas, para acompanhar os atos de seus membros até o momento mais apropriado para a obtenção da prova e efetuar suas prisões. Por meio da disciplina desse instituto, segundo Antonio Scarance Fernandes (Crime Organizado. Op. cit. p. 42), a autoridade policial poderá deixar de realizar a prisão em flagrante no momento mais propício para agir e, assim, obter a prova. Daí as denominações flagrante prorrogado ou retardado, aventadas pela doutrina para designar a situação que decorre da ação controlada, em consonância com o disposto no artigo 303 do Código de Processo Penal, que prevê que para as infrações permanentes "entende-se o agente em flagrante delito enquanto não cessar a permanência"' (SILVA, Eduardo Araujo da. Op. cit. p. 83).

${ }^{123}$ É preciso cautela da autoridade policial e de seus agentes na utilização da ação controlada, fundando-se na proporcionalidade e na razoabilidade. Imagine-se que uma organização criminosa resolva exterminar testemunhas. Não poderá o agente policial, que se aproxime da referida organização, protelar a prisão em flagrante, permitindo que várias mortes ocorram, a pretexto de colher mais provas para capturar o maior número possível de envolvidos. Não é razoável, nem proporcional à finalidade da lei. Pode-se tolerar um crime financeiro qualquer, para que outro seja cometido, até que se atinjam um montante confiável de provas. Tal situação se desenha proporcional ao retardamento do flagrante e dá o contorno do razoável à atuação do Estado no combate ao crime organizado (NUCCI, Guilherme de Souza. Op. cit. p. 203).

${ }^{124}$ Nucci (Op. cit. p. 202) defende que a única hipótese de ação controlada refere-se à organização criminosa, não valendo para o cenário das infrações cometidas por quadrilha ou bando ou outra forma de associação criminosa. Isto porque, segundo a opinião do autor, se o legislador fez questão de discriminar, no artigo $1^{\circ}$, que há várias espécies de agrupamentos (quadrilha ou bando, organização criminosa e associação criminosa de qualquer tipo), referindo-se, neste inciso, somente à organização criminosa, o flagrante protelado tem cabimento restrito. Por outro lado, Antonio Scarance Fernandes sustenta que a ação controlada é permitida ainda quando não se trate efetivamente de organização criminosa, pois a lei autoriza, como medida cautelar, quando as circunstâncias concretas fizerem supor tratar-se de "ação praticada por organizações criminosas" (FERNANDES, Antonio Scarance. $O$ Equilíbrio...Op. cit. p. 248). Silva (Op. cit. p. 83), por seu turno, lembra que: "Em que pese ao tratamento legal específico para a apuração do crime organizado, o emprego da ação controlada visando apurar a prática de conduta que não tenha relação com a criminalidade organizada pode ser resolvida no campo do direito 
observação e acompanhamento para que a medida legal se concretize no momento mais eficaz $^{125}$ do ponto de vista da formação de provas e fornecimento de informações.

De fato, o objetivo maior da ação controlada consiste em aguardar, esperar pelo melhor momento para a atuação policial repressiva ${ }^{126}$ contra os integrantes da organização criminosa, formando provas e coletando informações, tudo com o intuito de desmantelar a organização ${ }^{127}$. Entre agir reprimindo o ato imediatamente (geralmente com a prisão em flagrante $)^{128}{ }_{-}^{129}$ ou deixar o ato desenvolver-se, sob vigilância policial, opta-se pela

material. Assim é que o agente policial que retarda sua intervenção para aguardar o momento mais adequado para cumprir com seu dever funcional de interromper o crime em curso não age com o dolo específico de "satisfação de interesse ou sentimento pessoal" exigido pelo legislador penal, mas com a finalidade de aguardar o melhor momento para surpreender o autor do delito. E, assim, não pratica crime de prevaricação, por ausência do elemento subjetivo do tipo. Para Luiz Flávio Gomes, "somente é possível esta espécie de flagrante diante da ocorrência do crime organizado, ou seja, somente em ação praticada por organizações criminosas ou a elas vinculada. Fora da organização criminosa é impossível tal medida" (GOMES, Luiz Flávio; CERVINI, Raúl. Crime Organizado. Op. Cit. p. 117). Diante desta afirmação de Gomes, Capez passa a observar que: "Em sendo assim, podemos constatar que o artigo $2^{\circ}$, inciso II, é inaplicável. Isso porque, em virtude de uma falha de sua redação, somente se emprega às organizações criminosas. E, como a partir da entrada em vigor da Lei $n^{\circ}$ 10.217/01, ficou clara a distinção entre quadrilha ou bando, associação criminosa e organização criminosa, e considerando que não existe qualquer definição legal do que venha a ser esta última, o dispositivo diz respeito a algo que, juridicamente, ainda não existe.

${ }^{125}$ De acordo com Mendroni: "Concede-se à Polícia o direito de aguardar a oportunidade mais eficiente para atuar, seja prender, surpreender, ou agir, de qualquer forma, de modo que no momento oportuno - segundo a interpretação dos agentes que participam da operação - a situação seja mais favorável para a obtenção de provas. Pode ser praticada, no que couber, em forma de flagrante esperado (admitido pela jurisprudência), na medida em que a Polícia não só recebe a notícia da prática de um crime para então aguardá-lo, de campana, como também observa à distância os passos de integrantes da organização criminosa, monitorando-os com eventual escuta telefônica e outros expedientes investigatórios, para então agir no momento considerado mais oportuno. Assim, enquanto houver sequência de acompanhamento da situação de flagrante, nos termos dos incisos do artigo $302 \mathrm{e}$ seguintes do Código de Processo Penal, existirá a possibilidade da execução da prisão dentro dos critérios da prisão em flagrante. Se, por exemplo, a polícia perseguir determinados componentes de um grupo após a prática de um crime, não havendo interrupção, mesmo que os criminosos não percebam a perseguição, decidindo pela prisão esta poderá ocorrer ainda em situação de flagrante. Por outro lado, desfigurando-se aquelas possibilidades, não será possível ocorrência de prisão em flagrante, mas somente através de correspondente ordem judicial" (MENDRONI, Op. Cit. p. 50).

${ }^{126}$ Ada Pellegrini Grinover, comentando a legislação italiana antimáfia, esclarece: "nas disposições processuais da lei, autoriza-se o retardamento, pelo Ministério Público e pela Polícia Judiciária, de medidas cautelares de sua competência, nos casos de extorsão, de 'reciclagem' e de emprego de dinheiro, bens e utilidades de procedência ilícita" (GRINOVER, Ada Pellegrini. O Crime organizado no sistema italiano. Justiça Penal, no 3, RT, 1995, p. 22).

${ }^{127}$ Neste diapasão Mário Sérgio Sobrinho (op. Cit. p. 43) observa que finalísticamente "empregar a ação controlada permite minimizar a utilidade do segredo, característica que reina entre os membros dessas organizações, bem como atingir mais facilmente os dirigentes das atividades ilícitas praticadas por elas, os quais procuram se afastar, sistematicamente, da execução das atividades mais rotineiras e visíveis relacionadas com a prática do crime, bem como facilita o reconhecimento daqueles outros membros da organização que se envolverem com práticas executivas do crime.

${ }^{128}$ Não se deve confundir o flagrante prorrogado ou retardado, previsto na Lei do Crime Organizado, com o flagrante esperado, em que a posição da polícia limita-se à mera expectativa, sendo a prisão efetuada no primeiro 
segunda possibilidade. Porém, de se atentar que a ação controlada é uma técnica investigativa, acima de tudo e não propriamente uma modalidade de liberação da prisão em flagrante delito.

Questão nebulosa do instituto refere-se ao procedimento e controle de sua utilização. No Brasil, quando da edição da Lei $n^{0} 10.217 / 01$, o legislador perdeu boa oportunidade para estabelecer expressamente os critérios da ação controlada ${ }^{130}$, uma vez que, pelo teor da redação do inciso II, da Lei do Crime Organizado não fica claro se esse controle deve incumbir ao Ministério Público, seguindo a tendência internacional ${ }^{131}$, ou ao Juiz de Direito $^{132}$.

momento da ação criminosa, sem possibilidade de retardamento. No prorrogado, pelo contrário, o agente policial tem discricionariedade quanto ao momento da prisão. Também não se confunde com o flagrante preparado ou provocado em que a ação da polícia consiste em incitar o agente à prática de delito, retirando-lhe qualquer iniciativa e, dessa maneira, afetando a voluntariedade do ato. Nesse caso, ao contrário do flagrante prorrogado, não existe mera expectativa, porque a polícia interfere decisivamente no processo causal. $\mathrm{O}$ agente torna-se simples protagonista de uma farsa, dentro do qual o crime não tem, desde o início, nenhuma possibilidade de consumar-se. A polícia provoca a situação e se prepara para impedir a consumação. Por essa razão, a jurisprudência entende que há crime impossível (Súmula 145 do STF) (CAPEZ, Fernando. Curso de Direito Penal. Legislação Penal Especial. Volume 4. São Paulo: Editora Saraiva, 2006, p. 240).

${ }^{129}$ Nesse sentido Eduardo Araújo da Silva assevera que a criação da ação controlada decorreu da demonstração prática de ser mais produtivo evitar a prisão prematura daqueles que integram organizações criminosas. Seu objetivo é retardar esse momento e manter as ações do crime monitoradas para identificar maior número de integrantes ou atingir aqueles que lideram o grupo. Trata-se de medida adotada para fazer frente à criminalidade nos últimos tempos, exigindo prolongados períodos de observação e monitoramento dos componentes da organização criminosa, sem falar no emprego das demais técnicas de obtenção de prova (Op. Cit. p. 83).

${ }^{130}$ Embora não prevista na Lei do Crime Organizado, a autorização judicial prévia é exigida pela Lei ${ }^{\circ}$ 11.343/2006 para os crimes relacionados com entorpecentes. Essa providência, como aponta Mário Sérgio Sobrinho (Op. Cit. p. 44), deve ser adotada em todos os casos de emprego da ação controlada, pois é eficaz para minimizar eventuais e possíveis violações da intimidade e vida privada das pessoas submetidas à mencionada técnica de investigação.

131 Observa Vaggione: “Na Itália, o Decreto Presidencial 309/1990 disciplina a ação controlada, com o retardamento da prática de atos de ofício para a obtenção de provas relevantes e prisão dos responsáveis pelo tráfico de drogas. A autoridade judicial pode retardar a emissão de ordens de prisão e sequestro ou postergar a execução de ordem já emitida. Até mesmo a autoridade policial pode retardar a prática de atos que seriam de sua atribuição (prisão em flagrante, execução de ordem de prisão etc.), mas avisando o Ministério Público. Incumbe ao Ministério Público a imposição de diretivas para que a Polícia Judiciária fiscalize as ações controladas. A lei 82/1991 dispõe sobre ações controladas em matéria de extorsão mediante sequestro, e a Lei 172/1992 disciplina ações controladas em matéria de extorsão, usura e lavagem de dinheiro" (VAGGIONE, Luiz Fernando e SILVEIRA, Rodrigo Mansour Magalhães. O Crime Organizado na Itália e as medidas adotadas para o seu combate. In: Crime Organizado, Op.cit. p. 246.)

${ }^{132}$ No Brasil, ante a pobreza na especificação pelo artigo $2^{\circ}$ da Lei 9.034/95, dos requisitos necessários para a ação controlada, apontava-se como forma de complementação o uso por analogia da lei de interceptações telefônicas (Lei $\mathrm{n}^{\circ}$ 9.296/1996) e, com base nesta, exigir-se autorização do juiz, não prevista na Lei do Crime Organizado (BORGES, Paulo César Corrêa. Crime Organizado. São Paulo: Associação paulista do Ministério Público, 2000. p. 53-57). 
Para Geraldo Prado e William Douglas ${ }^{133}$ : “como podem ocorrer $\operatorname{abusos}^{134}$, melhor seria que a lei tivesse condicionado a ação à autorização judicial ${ }^{135}$, como estava no projeto inicial, ou pelo menos que exigisse a previa comunicação da ação controlada $^{136}$, com o necessário sigilo, ao órgão do Ministério Público, preferencialmente, ou ao juiz competente". A falta de autorização deveria ser a exceção, admitida em casos de urgência, com comunicação ao juiz assim que cessada a situação de premência ${ }^{137}$, mas não é o que ficou consignado em lei.

A nova Lei de Drogas (Lei $\mathrm{n}^{\circ}$ 11.343/06) - quando considerado que seu inciso II, do artigo 53, refere-se à ação controlada ${ }^{138}$ - serve para suprir, em parte, as lacunas da Lei do Crime Organizado ${ }^{139}$. Isto porque, a Lei Antidrogas exige autorização judicial, após a prévia manifestação do Ministério Público, o que pode ser interpretada como obrigatoriedade extensível à ação controlada, quando aplicada com base na lei do crime organizado.

\footnotetext{
${ }^{133}$ PRADO, Geraldo e DOUGLAS, William. Op. Cit. p.50.

${ }^{134}$ Isto porque, no caso concreto, imagine-se o exemplo em que um mau policial efetivamente dá guarida ou proteção a um grupo criminoso durante o cometimento de seus ilícitos. Sem prévia autorização do magistrado, ou seja, sem o necessário controle judicial, fácil seria a sua argumentação de utilização da ação controlada decorrente de decisão tomada por conta própria - e com isto poderia ter, muito provavelmente, a sua responsabilização penal afastada (MENDRONI, Marcelo Batlouni. Op. Cit. p. 50). No entanto, ressalva Antonio Scarance Fernandes "eventual frustração na ação, perdendo-se a situação de flagrância, desde que justificada pelas circunstâncias, não poderá caracterizar atuação ilícita da autoridade policial" (FERNANDES, Antonio Scarance. Op. cit. p. 248).

${ }^{135}$ Mendroni faz uma analogia para afirmar que a ação controlada necessita de autorização judicial, pois: "Como a ação controlada deve ser praticada por agente infiltrado, e a lei ${ }^{\circ} 10.217 / 01$ prevê expressamente a necessidade de autorização judicial para esta operação - infiltração de agentes ("mediante circunstanciada autorização judicial") - torna-se dedutivo que ambas (ação controlada e infiltração de agentes) deverão ser autorizadas judicialmente. Essa autorização significa, implicitamente, permitir ao agente policial ou de inteligência - em tarefas de investigação - retardar a sua interdição, nas ações supostamente praticada por organização criminosa, ou a ela vinculada, para que a medida se concretize no momento mais eficaz do ponto de vista de provas e fornecimento de informações. Significa, em outras palavras, autorização para que o policial tenha sob seu controle a prática do(s) crime(s) praticado(s) por integrantes da organização criminosa" (Op. cit. p. 52).

${ }^{136}$ Para Mendroni: "Em caso de não-comunicação prévia acompanhada da autorização, a ação controlada estaria vedada pelo policial e a sua eventual participação/atuação em organização criminosa não terá, até prova em contrária, o possível acobertamento da excludente de antijuridicidade, o estrito cumprimento do dever legal. Assim, com a autorização judicial a excludente torna-se mais visível, ao passo que sem ela a presunção toma sentido contrário, de que o policial, tenha atuado criminosamente; a não ser que ele, policial, demonstre o contrário, como por exemplo, a inafastável necessidade de sua atuação de emergência, sem tempo hábil ao devido requerimento judicial" (Op. cit. p.55).

${ }^{137}$ FERNANDES, Antonio Scarance. Op. Cit. p.248.

${ }^{138}$ Posição de Vicente Greco Filho, Damásio de Jesus, Sérgio Ricardo de Souza, dentre outros.

${ }^{139}$ Essa é a posição de Antonio Scarance Fernandes (O Equilíbrio na Repressão ao Crime Organizado. In: Crime Organizado. Op. cit. p. 17).
} 


\subsubsection{Entrega vigiada $X$ Ação controlada}

Muito provavelmente, um dos principais desafios deste trabalho - ou talvez o maior deles - consiste em distinguir ação controlada da entrega vigiada ${ }^{140}$. O posicionamento adotado nesta análise refletirá diretamente na questão a ser enfrentada no capítulo seguinte, quando da verificação da existência ou não de previsão legal da entrega vigiada no Brasil.

Isto porque, no caso específico, se for possível sustentar que embora haja diferença de denominação ${ }^{141}$ (nomes diversos) entre a entrega vigiada e ação controlada, não existe diferença de essência entre os institutos, pode-se, então, concluir, que há previsão legal da entrega vigiada nos diplomas legais brasileiros, já que ausente de dúvida que a ação controlada encontra-se estampada em lei ordinária brasileira (art. $2^{\circ}$, inciso II, da Lei do Crime Organizado).

De outro lado, constatado que existe distinção entre os dois institutos em exame, deverá ser apontado onde se encontra a previsão legal da entrega vigiada na legislação ordinária, já que não se lhe aplicariam os dispositivos atinentes à ação controlada, porquanto institutos diversos. Daí porque a complexidade do exame. E mais, visto que os tópicos estão interligados, caso se parta da premissa equivocada, muito possivelmente a análise do capítulo seguinte (existência da previsão legal da entrega vigiada no Brasil) restará prejudicada.

\footnotetext{
${ }^{140}$ Consoante Pereira: "É comum a distinção conceitual entre a entrega (ou ação) vigiada e a controlada. Essa última consistiria na ação de retardar a interdição policial do que se supõe tratar-se de ação praticada por organizações criminosas ou a elas vinculada, desde que mantida sob observação e acompanhamento para que a medida legal se concretize no momento mais eficaz, do ponto de vista da formação de provas e fornecimento de informações. Já a entrega vigiada, seria um meio de investigação a ser utilizado, exclusivamente, com relação aos fatos envolvendo o tráfico ilícito de drogas" (PEREIRA, Flávio Cardoso. Meios extraordinários de investigação criminal. Infiltrações policiais $e$ entregas vigiadas (controladas), In: <http://jus2.uol.com.br/doutrina/texto.asp?id=11258>).

${ }^{141}$ No entender de Rodrigo Gomes Carneiro: "A ação controlada e a entrega vigiada são terminologias diversas, embora usadas indistintamente, talvez porque ambas tenham idêntico objetivo: maior eficácia probatória e repressiva na medida em que possibilitam a identificação do maior número de integrantes de uma quadrilha ou organização criminosa" (GOMES, Rodrigo Carneiro. O Crime Organizado na Visão da Convenção de Palermo. Belo Horizonte: Del Rey, 2009, p. 206).
} 
De início, cabe ressaltar que ambas as técnicas são muito semelhantes. Isto porque tanto a ação controlada como a entrega vigiada buscam objetivos semelhantes, qual seja, alcançar a base da organização, desvendando seu modo de agir e coletando o maior número de provas possível. Ademais, as duas técnicas de investigação podem ser traduzidas como ato de monitorar, vigiar e acompanhar para que qualquer medida interventiva se concretize no momento mais eficaz.

Todavia, por primeiro, de se observar que a ação controlada é mais ampla que a entrega vigiada. A ação controlada, prevista como procedimento de investigação e formação de provas a ser utilizada em qualquer fase da persecução criminal consiste, conforme inciso II, do artigo $2^{\circ}$, da Lei 9.034/95, em "retardar a interdição policial do que se supõe tratar-se de ação praticada por organizações criminosas ou a ela vinculada, desde que mantida sob observação e acompanhamento para que a medida legal se concretize no momento mais eficaz do ponto de vista da formação de provas e fornecimento de informações".

A ação controlada é uma exceção ao flagrante obrigatório previsto em lei para a autoridade policial e seus agentes. ${ }^{142}$ Refere-se ao chamado flagrante "diferido", ou "prorrogado" ou, ainda, "postergado", situação em que o policial, por autorização legal, pode aguardar o melhor momento para prender uma pessoa em flagrante, para obtenção de um maior número de provas. Assim, a ação controlada é utilizada para a investigação de todo e qualquer crime praticado por organizações criminosas ou a ela vinculada.

Por sua vez, a entrega vigiada é definida pela doutrina, em especial a estrangeira $^{143}$, como a técnica consistente em permitir que remessas ilícitas ou suspeitas de

\footnotetext{
${ }^{142}$ Prevê o artigo 301, do Código de Processo Penal, a obrigatoriedade por parte das autoridades policiais e seus agentes de prender todo aquele que se encontrar em flagrante delito: "Qualquer do povo poderá e as autoridades policiais e seus agentes deverão prender quem quer que seja encontrado em flagrante delito".

${ }_{143}$ Consultar: a) SALDARRIAGA, Victor Roberto Prado. La Entrega Vigilada: orígenes y desarrollos, b) MONTOYA, Mario Daniel. Informantes y Técnicas de Investigación Encubiertas. Análisis Constitucional y Procesal Penal, $2^{\mathrm{a}}$ edição, Editora Ad Hoc, Buenos Aires; c) EDWARDS, Carlos Enrique. El arrepentido, el agente encubierto y la entrega vigilada. Modificación a la Ley de Estupefacientes. Análisis de la ley 24.424, Editora Ad Hoc, Buenos Aires; d) SOUZA, Sergio Ricardo de. A Nova Lei Antidrogas. Editora Impetus, $2^{\mathrm{a}}$ edição, pág. 144. Para EDWARDS: "La entrega vigilada es una nueva forma de investigación en la lucha contra la narcocriminalidad, que supone el tráfico de una remesa de estupefacientes entre dos o más países. La entrega
} 
entorpecentes ou outras substâncias proibidas circulem pelo território nacional, bem como dele saiam ou nele ingressem, sem interferência impeditiva da autoridade ou seus agentes, mas sob sua vigilância, de forma monitorada. Tudo com o fim de descobrir ou identificar as pessoas envolvidas no cometimento de algum delito de elevada gravidade, desvendar seu modus operandi, bem como prestar auxílio a autoridades estrangeiras nesses mesmos fins.

Rodrigo Carneiro Gomes ${ }^{144}$ diferenciando os institutos ressalta que: "A entrega vigiada, como técnica investigativa, não gera ação policial repressiva, embora possa a ter como consequência, num momento futuro e, assim, não há que ser confundido com o "flagrante esperado". Como há um mero "acompanhamento" ou "vigilância", o efetivo policial destinado para a ação controlada é restrito, limitado, sem recursos materiais e humanos adequados para uma atuação repressiva estatal imediata que acarrete a prisão dos suspeitos identificados, o que feriria os fins da Lei 9.034/95, do Decreto 5.015/2004 e instrumentos legislativos correlatos, pois não revelada, ainda, toda a cadeia de domínio e divisão de tarefas".

Quanto ao agente, a definição legal da ação controlada dispõe expressamente sobre 'a não atuação de policiais ${ }^{145}$, fazendo crer que somente estes estariam legitimados para atuar nessa técnica, enquanto que a entrega vigiada indica que não há a obrigatoriedade do ato ser monitorado tão somente por policiais. Assim, a lei poderia legitimar não apenas os policiais, mas também outros agentes para a execução de referida técnica investigatória.

vigilada puede ser definida como una técnica investigativa por la cual la autoridad judicial permite un cargamento de estupefacientes, que se envía ocultamente a través de cualquier medio de transporte, pueda llegar a su lugar de destino sin ser interceptada, a fin de individualizar al remitente, destinatario y demás participes de esta maniobra delictiva" (El arrepentido, el agente encubierto y la entrega vigilada. Buenos Aires, Ed. Ad Hoc, 1996, p. 107).

${ }_{144}$ Op. cit. p. 219.

${ }^{145}$ No sentido de que a ação controlada deve ser desenvolvida exclusivamente por policiais, Rodrigo Carneiro Gomes descreve: "Ação controlada, segunda a Lei ${ }^{\circ}$ 9.034/95 (lei federal brasileira que trata do crime organizado, posteriormente alteradas pelas Leis $\mathrm{n}^{\circ} 9.080 / 1995$ e $\left.\mathrm{n}^{\circ} 10.217 / 01\right)$, é a técnica investigativa que consiste no retardamento da ação, necessariamente policial (em sentido estrito), repressiva, em favor do controle e do acompanhamento das ações ilícitas, até o momento mais oportuno para a intervenção" (GOMES, Rodrigo Carneiro. O Crime Organizado na Visão da Convenção de Palermo. Belo Horizonte: Del Rey, 2009, p. 204). 
Com relação ao ato a ser vigiado, possível constatar ser a ação controlada mais ampla ${ }^{146}$, porque o monitoramento pode envolver qualquer prática ilícita durante o iter criminis em que se deixa de operar o flagrante. Assim, por exemplo, o ato de negociação entre os agentes da organização criminosa - seja entre eles ou com terceira pessoa alheia à organização -, o ato de se desfazer de provas essenciais à comprovação dos crimes cometidos pela organização, o ato de constranger testemunhas, o ato extremo de monitorar a execução de pessoas, são todos exemplos de atos que podem ser acompanhados pelos policiais (estejam infiltrados ou não), que decidem por não intervir imediatamente no momento do cometimento do crime, para aguardar o melhor momento do flagrante, desmantelando a quadrilha por inteiro. Já a entrega vigiada diz respeito estritamente ao monitoramento do deslocamento da remessa de mercadoria ilícita, seja de entorpecentes, armas, dinheiro ou outro objeto.

Assim, dá-se a entrega vigiada quando o ato da não atuação policial (ou de outro agente vigilante destacado pela lei) coincidir, justamente, no monitoramento de remessas ilícitas de mercadorias, com algumas peculiaridades próprias do instituto. Vê-se, então, a grande similitude entre os institutos, o que, via de regra, faz emergir grande confusão entre eles.

Outra diferença que pode ser apontada refere-se ao local de aplicação das técnicas ora tratadas. A ação controlada, com previsão na legislação ordinária, tem seu campo de atuação limitada ao direito interno, ou seja, dentro do Estado ${ }^{147}$. Não há referência, ao menos legal, da possibilidade de aplicação da ação controlada fora do âmbito interno. Por sua

\footnotetext{
${ }^{146}$ Neste diapasão, Gomes sustenta que: "O conceito de ação controlada é mais amplo, pois permite o controle e vigilância (observação e acompanhamento, no texto legal) de qualquer ação criminosa e não apenas a entrega vigiada de entorpecentes (Convenção de Viena de 1988 - Convenção contra o Tráfico Ilícito de Entorpecentes e Substâncias Psicotrópicas, aprovada pelo Decreto Legislativo 162, de 14/09/91 e incorporada ao ordenamento jurídico pátrio pelo Decreto 154 de 26.06.1991) e de armas (Convenção Interamericana contra a Fabricação e o Tráfico Ilícito de Armas de fogo, munições, explosivos e outros materiais correlatos, adotada pelo Decreto 3.229/99, complementado pelo Decreto 5.941/2006), pois é instrumento de largo espectro que pode ser utilizado na repressão de organizações criminosas ligadas ao contrabando e no pagamento ou recebimento de propina, na forma da Convenção das Nações Unidas contra a Corrupção, incorporada legalmente por meio do Decreto 5.687/2006. Pode-se considerar, assim, que a entrega vigiada é uma das modalidades da ação controlada". (GOMES, Rodrigo Carneiro. O Crime Organizado na Visão da Convenção de Palermo. Belo Horizonte: Del Rey, 2009, p. 204).

${ }^{147}$ Gomes destaca que a ação controlada tem aplicação interna, quando aduz que: "O artigo $2^{\circ}$, inciso II, da Lei 9.034/1995 trata desse mecanismo específico de combate ao crime organizado sem aludir à dimensão internacional" (GOMES, Rodrigo Carneiro. O Crime Organizado na Visão da Convenção de Palermo. Belo Horizonte: Del Rey, 2009, p. 204).
} 
vez, a entrega vigiada, que nasceu de acordo internacional, pode ser utilizada em nível internacional, isto é, entre países distintos, desde que obedecidos os requisitos e haja tratado internacional de cooperação ou acordo entre os países envolvidos na operação.

Neste aspecto, de se observar que a entrega vigiada pode ser considerada um instrumento de cooperação internacional. Isto porque, diferentemente da ação controlada que tem previsão legal de aplicação apenas no âmbito interno, a entrega vigiada pode ser empregada entre Países. Com isso, passará a representar não apenas uma técnica de investigação, como também um meio de cooperação internacional.

Há quem sustente, ainda, diferença entre os institutos, tomando por base a necessidade da aplicação da técnica em conjunto com a infiltração de agentes ${ }^{148}$. É o que aponta Vicente Greco Filho ${ }^{149}$ : "No direito francês, há uma diferença entre entrega vigiada e a entrega controlada. Na primeira, a mercadoria ilegal é objeto de vigilância passiva por parte das autoridades; na segunda, é utilizado o recurso de agentes infiltrados que participam diretamente da operação". E prossegue o ilustre doutrinador: "No direito brasileiro a distinção não tem relevância, porque, com a combinação, ou não, dos dois incisos do art. 53 da Lei 11.343/2006 (lei de Drogas), os requisitos para a autorização e seus efeitos são os mesmos ${ }^{150 "}$.

No tocante à autorização judicial, os institutos têm aplicabilidade diversa. Isto porque a Lei $n^{\circ} 9.034 / 95$, no art. $2^{\circ}$, inciso II, ao tratar da ação controlada deixa de exigir a

${ }^{148}$ Interessante trazer a posição de Flávio Cardoso Pereira, quando diferencia os institutos da entrega vigiada e ação controlada, mencionando a ligação com a infiltração de agentes: "Assim, tratando-se de uma entrega controlada, ocorreria uma observação feita pela polícia, via normalmente de infiltração de agentes policiais, em um determinado ambiente criminoso ou não, para fins de coleta de informações e provas que possam conduzir a posterior prisão dos envolvidos. Imagine-se a possibilidade de que um policial se infiltre dentro de um organismo estatal com vistas a detectar qual o modus operandi e quem seriam os agentes públicos que estariam praticando crimes contra a Administração Pública. Conclui-se, pois, consistir em uma ação para retardar a interdição policial do que se supõe tratar-se de ação praticada por organizações criminosas ou a elas vinculadas, desde que mantida sob observação e acompanhamento para que a medida legal se concretize no momento mais eficaz do ponto de vista da formação de provas e fornecimento de informações. De forma distinta, a entrega vigiada, em um primeiro aspecto, consiste basicamente em uma estratégia policial empregada em investigações, que permite a passagem de certa quantidade de drogas por um determinado território, apesar do conhecimento dos órgãos de repressão estatal, permitindo a continuação normal' da viagem, porém, desde que se proceda a um controle secreto (acompanhamento), durante todo o percurso, na expectativa posterior de apreensão da carga ilícita, bem como dos seus remetentes e destinatários" (PEREIRA, Flávio Cardoso. A Moderna Investigação. Op. cit. p. 122).

149 FILHO, Vicente Greco. A Entrega Vigiada e Tráfico de Pessoas. In: JÚNIOR, Laerte Marzagão (coord.). Tráfico de Pessoas. Ed. Quartien Latin do Brasil: São Paulo, 2010, p. 295.

${ }^{150}$ Idem, p. 295. 
autorização judicial ${ }^{151}$ para o emprego de referida técnica ${ }^{152}$. Porém, os acordos internacionais, as normas Estrangeiras constantes de diplomas de outros Estados e até mesmo a legislação interna (para aqueles que sustentam que a nova Lei de drogas $n^{\circ} 11.343 / 2006$ regulamenta o instituto da entrega vigiada) exigem a autorização judicial ou, ao menos, de outra autoridade legalmente apontada como competente, para a licitude e utilização da entrega vigiada. Assim, enquanto a ação controlada estaria afeta à decisão e discricionariedade do agente policial para postergar o flagrante, a entrega vigiada partiria de uma ordem do magistrado (ou outra autoridade que a legislação vier a legitimar) a este agente policial, para monitorar a remessa ilícita sem apreendê-la.

Embora haja diferenças tênues e pontuais entre os dois institutos, no tocante aos crimes existe uma aparente diferença, quando se faz crer que a entrega vigiada deve ser aplicada tão somente como meio de investigação relacionado ao tráfico de drogas e entorpecentes. A entrega vigiada, inicialmente prevista para fazer frente ao tráfico de drogas, se estendeu e passou a ser empregada como técnica investigatória para combater outros objetos ilícitos ${ }^{153}$, assemelhando-se, nesse ponto, à ação controlada.

${ }^{151}$ Como observa Rodrigo Carneiro Gomes: “A Lei no 9.034/95 prevê como únicas restrições à utilização do mecanismo da 'ação controlada' a observação e acompanhamento com o objetivo de que a medida legal se concretize no momento mais eficaz do ponto de vista da formação de provas e fornecimento de informações. Não explicita a necessidade de autorização judicial, ao contrário do que acontece com a infiltração policial e a interceptação ambiental" (Op. cit., p. 214).

${ }^{152}$ Consoante anotação de Nucci: "Na lei no $9.034 / 95$ não se exige que a polícia busque autorização do juiz, com a oitiva prévia do Ministério Público. Tal situação se afigura um risco para a distinção entre a real atuação policial, retardando o flagrante para conseguir mais provas, e a participação policial no esquema criminoso. O correto seria, sempre, a fiscalização do magistrado e do representante do Ministério Público. A menção, neste inciso, à mantença da observação e acompanhamento não significa vincular a atuação da polícia à autorização judicial, mas, sim, que a ação controlada precisa ser devidamente acompanhada e observada, possivelmente pelas autoridades policiais em relação aos seus subordinados". Na mesma posição que sustentamos: Paulo César Corrêa Borges e Antonio Scarance Fernandes (cf. Corrêa Borges, O crime organizado, p. 75). Em contrário, crendo indispensável autorização judicial, para que não se revele uma "ação descontrolada", porém sem embasamento em lei, está a posição de Marcelo Batlouni Mendroni (Crime organizado, p. 65).

${ }^{153}$ Em artigo publicado no IBCCRIM (RASCOVSKI, Luiz e NEISTEIN, Mariângela Lopes. Alguns Aspectos Referentes à Entrega Vigiada no Direito Brasileiro. Informativo Eletrônico do Instituto Brasileiro de Ciências Criminais - IBCCRIM, julho de 2007), quando tratado da diferença entre os dois institutos, cheguei a sustentar que: "a ação controlada é utilizada para a investigação de todo e qualquer crime que venha a ser praticado por organizações criminosas. Ao contrário, a entrega vigiada é um meio de investigação típico do crime de tráfico internacional de entorpecentes, em que é autorizado o controle do tráfego de drogas que circulem dentro ou fora do país". Hoje mudei de opinião. Isto porque a entrega vigiada - que realmente surgiu como técnica de monitoramento de remessas ilícitas de substâncias entorpecentes - passou a ter previsão de aplicação em diversos tratados internacionais para outros objetos, que não só entorpecentes. Assim, deixou de ser um meio de investigação exclusivo de enfrentamento ao crime organizado de drogas, estendendo para o combate do tráfico de armas, de lavagem de dinheiro, jóias ou qualquer outro bem de valor, com previsão em diversos tratados 
De se notar, entretanto, que embora as técnicas em exame guardem pontos de semelhança, apresentam pontos divergentes, que permitem sustentar tratar-se de institutos diversos.

Essa dessemelhança, diante do exposto, pode ser sintetizada nos seguintes pontos: 1) quanto ao verbo/conduta: a ação controlada consiste em retardar a interdição policial do que se supõe ação praticada por organizações criminosas ou a ela vinculada, enquanto que por entrega vigiada se entende a técnica que permite que remessas ilícitas ou suspeitas transitem com o conhecimento e sob a supervisão de suas autoridades competentes; 2) quanto à extensão (ato a ser vigiado): a ação controlada é mais ampla que a entrega vigiada. Isto porque a ação controlada permite a não atuação policial para diversas ações, enquanto que a entrega vigiada está adstrita à ação de monitorar remessas ilícitas; 3) quanto à necessidade de autorização da autoridade competente: a ação controlada independe de autorização judicial, ao passo que a entrega vigiada depende de autorização judicial ou, ao menos, de outra autoridade legalmente prevista; 4) quanto ao âmbito de aplicação: a entrega vigiada pode ser utilizada no âmbito interno e internacional, inclusive como forma de cooperação entre Países. Já a ação controlada só tem aplicabilidade interna; 5) quanto ao agente: a legislação relativa à ação controlada dispõe expressamente sobre a não atuação de policiais. Por seu turno, a entrega vigiada permite que se prevejam outros agentes, que não policiais, para a execução da técnica.

internacionais. Neste aspecto, a entrega vigiada não está - como muito sustentam - adstrita tão somente aos crimes de drogas. Se assim fosse, estar-se-ía negando vigência aos diversos tratados ratificados pelos Brasil que dispõem sobre a aplicação da entrega vigiada a outros ilícitos que não de drogas. 


\title{
CAPÍtUUlO II \\ PREVISÃO NORMATIVA DA ENTREGA VIGIADA
}

\subsection{Origem e evolução normativa da entrega vigiada}

\begin{abstract}
A entrega vigiada surgiu ${ }^{154}$ da iminente necessidade de criação de métodos investigatórios mais eficazes no enfrentamento à criminalidade organizada. A delinquência contemporânea assume características globais, valendo-se de todos os meios que a tecnologia atual pode oferecer para atingir seus objetivos ilícitos. Ao mesmo tempo, tende a se conectar com máfias de vários países, inclusive se vinculando em importantes segmentos do Poder Estatal.
\end{abstract}

É justamente neste contexto que emerge a figura da entrega vigiada para fazer frente ao desenvolvimento do crime organizado. Propaga-se a ideia de adoção de uma técnica investigativa que venha a permitir a vigilância de remessas ilícitas, entre países ou até mesmo no interior de um único Estado, a fim de desbaratar a quadrilha e atingir os membros de sua cúpula.

Inicialmente a figura da entrega vigiada foi criada com a ideia de sua utilização para o enfrentamento tão somente do narcotráfico, isto é, para fiscalizar e vigiar o trânsito de remessas ilícitas de entorpecentes. Com o passar do tempo começou a ser inserida em diversas convenções internacionais, referindo-se a objetos diversos. Deixou de ser apenas um método de combate ao tráfico de entorpecentes, passando a ser utilizada para vigiar a remessa de quaisquer tipos de mercadorias ilícitas ligadas à criminalidade organizada, tais como: remessa de dinheiro, valores, jóias, armas, contrabando.

${ }^{154}$ Claudia Moscato Santamaría aponta que desde os tempos mais remotos, verifica-se utilização de espiões e informantes. Os povos antigos utilizavam os espiões para descobrir quem eram seus inimigos na conquista e busca de terras. A autora apresenta a origem bíblica das técnicas encobertas, citando trechos da Bíblia que relatam que Moisés enviou exploradores à terra de Canaã. (SANTAMARÍA, Claudia Moscato. El agente encubierto en el estado de derecho. Buenos Aires: Editora La Ley, 2000, p. 6). 
Embora o instituto da entrega vigiada tenha se tornado conhecido a partir de sua inserção na Convenção de Viena de 1988 (ratificada por diversos países importantes, dando a impressão que surgiu nessa Convenção) esse meio de investigação foi previsto, originariamente, no Convênio de Schengen.

Assim, após sua primeira e tímida aparição no Convênio de Schengen, em 1985, a entrega vigiada ganhou contornos expressivos com sua previsão na Convenção de Viena, no ano de 1988. A partir daí começou a se alastrar por meio da inserção da técnica em diversas convenções internacionais entre países, para só então passar a ser regulamentado internamente em alguns dos países signatários, conquanto ainda aguarde detalhamento legislativo na maior parte dos países participantes.

Dentre as convenções que atualmente prevêem a figura da entrega vigiada temos: a Convenção de Viena de 20/12/1988, a Convenção Interamericana contra a fabricação e o tráfico ilícitos de armas de fogo, munições, explosivos e outros materiais correlatos Washington de 14/11/1997 (CIFTA), a Convenção das Nações Unidas contra o crime organizado transnacional (Convenção de Palermo) de 15/11/2000 e a Convenção das Nações Unidas contra a corrupção de 31/10/2003. Referidas convenções serão tratadas neste capítulo, especificamente na parte em que se referem à entrega vigiada, demonstrando a evolução normativa do instituto.

\subsubsection{Convênio de Schengen de 14/06/1985}

A entrega vigiada nasceu no seio de um Convênio entre Alemanha, Bélgica, França, Luxemburgo e os Países Baixos. Neste convênio, denominado Convênio de Schengen, foi a primeira vez que se utilizou a denominação "entrega vigiada", prevendo-a como técnica especial de investigação. 
O convênio de Schengen, celebrado em 14 de junho de 1985, recebeu este nome porque foi assinado em Schengen ${ }^{155}$, pequena vila no sudeste do Luxemburgo próximo ao ponto onde confluem as fronteiras de Alemanha, França e Luxemburgo.

O Acordo de Schengen, embora tenha mencionado pela primeira vez a entrega vigiada, tratou-a de forma passageira, uma vez que aludido convênio objetivava, basicamente, a instauração de um regime de livre circulação para todos os cidadãos nacionais dos Estados signatários. O acordo tinha como foco principal a consecução de uma convenção entre países europeus sobre uma política de livre circulação de pessoas no espaço geográfico da Europa.

$\mathrm{Na}$ verdade, o convênio visava à criação do espaço Schengen, que seria implantado a partir da supressão progressiva do controle nas fronteiras comuns. O Espaço Schengen, atualmente, permite a livre circulação de pessoas dentro dos países signatários sem ter que parar nas fronteiras e apresentar o seu passaporte. Porém, é necessário ser portador de um documento legal como, por exemplo, o Bilhete de Identidade. Além do mais, o Espaço Schengen não se relaciona com a livre circulação de mercadorias (embargos etc.) cuja entidade mediadora é União Europeia e os outros membros fora do bloco econômico.

À lista dos países originariamente signatários ${ }^{156}$ (Alemanha, Bélgica, França, Luxemburgo e Países Baixos) foram-se juntando outros: a Itália (1990), Espanha e Portugal (1991), Grécia (1992), Áustria (1995), Dinamarca, Finlândia, Islândia, Noruega e Suécia (1996), República Checa, Estônia, Hungria, Letônia, Lituânia, Malta, Polônia, Eslováquia, Eslovênia (2004), Suíça (2005), Bulgária e Romênia (2007). Mônaco, San Marino

\footnotetext{
${ }^{155}$ É parte do Município de Remerschen no cantão de Remich. Sua população em 2004 era de 425 habitantes. A vila tornou-se famosa em 14 de junho de 1985 quando o Acordo de Schengen foi firmado a bordo do barco Princesse Marie-Astrid no rio Mosela.

${ }^{156}$ Estes cinco Estados ratificaram o Convênio de Schengen, em 19 de Junho de 1990, no qual definem as condições e garantias da aplicação da livre circulação. O Convênio e as declarações e decisões aprovadas pelo Comitê Executivo do Espaço de Schengen formam o que se chama a herança de Schengen. No Tratado de Amsterdã foi decidido incorporar a citada herança, a partir de 1 de Maio de 1999, na União Europeia, dado que a livre circulação das pessoas é um dos principais objetivos do mercado único. Por outro lado, em 18 de Maio de 1999, a Europa firmou um acordo com a Islândia e a Noruega, Estados que não faziam parte de Schengen, associando-os à aplicação e desenvolvimento da herança de Schengen e regulando, deste modo, a sua participação no Espaço de Livre Circulação instaurado na União Europeia.
} 
e o Vaticano estão dentro do Acordo de Schengen por serem enclaves. A Islândia e a Noruega também assinaram este Convênio. Bulgária, Romênia, Chipre, Irlanda e Reino Unido não fazem parte do convênio.

A entrega vigiada foi contemplada no artigo 73, do texto do Convênio de Schengen, de 14 de junho de 1985, prevendo o seguinte:

1 - Em conformidade com sua Constituição e com seu ordenamento jurídico, as partes contratantes se comprometem a tomar medidas que permitam as entregas vigiadas do tráfico ilícito de entorpecentes e substâncias psicotrópicas.

2 - A decisão de se recorrer à entrega vigiada será adotada em cada caso concreto, tendo por base uma autorização prévia da primeira parte contratante.

3 - Cada parte contratante conservará o comando e o controle das atuações em seu território e estará autorizada a intervir.

Dessa primeira aparição da entrega vigiada algumas conclusões podem ser extraídas. A primeira delas é a maneira genérica ${ }^{157}$ como foi prevista a entrega vigiada, sem especificar o procedimento de sua utilização. Aliás, a falta de regulamentação na aplicação da entrega vigiada representa, até hoje, o seu grande obstáculo.

Além da forma genérica, o Convênio de Schengen previu a utilização da entrega vigiada apenas para o enfrentamento do tráfico de entorpecentes e substâncias psicotrópicas (assim como a Convenção de Viena).

\footnotetext{
${ }^{157}$ Neste sentido, Luis Fernando Rey Huidobro, Fiscal do Tribunal Superior de Justiça de Navarra, assevera que "é evidente que o artigo 73 do Convênio (assim como a Convenção de Viena de 1.988) obrigava a dar cumprimento ao seu conteúdo normativo, sem especificar a forma de sua relação, a qual deveria ser outorgada pelas partes envolvidas, em conformidade com seu ordenamento jurídico" (HUIDOBRO, Luis Fernando Rey. La entrega Vigilada de drogas. Revista del Ministerio Fiscal. Tradução livre do trecho original: "Es evidente que el artículo 73 del Convenio (así como la Convención de Viena de 1988) obligaban a dar cumplimiento a su contenido normativo, sin especificar la forma de su relación, la cual debía otorgarse por las partes implicadas de conformidad con su ordenamiento jurídico).
} 
Por fim, conforme previsto em Schengen, a entrega vigiada tem aplicação somente entre países, uma vez que o acordo não mencionou sua aplicação, como método investigativo, no interior de um mesmo país, intra fronteiras. Neste sentido, possível asseverar que a entrega vigiada desponta muito mais com a preocupação de se revelar como instrumento de cooperação entre os Estados signatários do acordo, do que como um meio de investigação propriamente dito, embora, tenha ínsita em sua aplicação uma técnica de investigação.

Apesar da forma tímida, a previsão da entrega vigiada no Convênio de Schengen pode ser considerada a origem desse meio investigatório, como novo e avançado mecanismo no combate à criminalidade organizada, merecendo aplausos a iniciativa dos países celebrantes do acordo.

\subsubsection{Convenção de Viena de 20/12/1988}

Diferentes Estados membros da ONU, reconhecendo que a erradicação do tráfico ilícito é uma responsabilidade coletiva de todos os Estados e que para esse fim seria necessária uma ação coordenada como marco de uma cooperação internacional, firmaram a Convenção de Viena.

A Convenção de Viena, realizada em 1988 com a finalidade de combater o tráfico de entorpecentes e por isso intitulada formalmente como Convenção contra o Tráfico Ilícito de Entorpecentes e Substâncias Psicotrópicas, previu diversos meios de investigação a serem utilizados pelos Estados no combate a esse tipo de criminalidade, dentre eles a entrega vigiada.

A entrega vigiada é um procedimento previsto e recomendado pelas Nações Unidas, na Convenção de Viena de 1988, nos artigos $1^{\circ}$, alínea "1" e no artigo 11, nos seguintes termos: 
"Artigo 1: Definições - Salvo indicação expressa em contrário, ou onde o contexto exigir outra interpretação, as seguintes definições se aplicarão em todo o texto desta Convenção:

Letra "l" - Por "entrega vigiada" se entende a técnica de deixar que remessas ilícitas ou suspeitas de entorpecentes, substâncias psicotrópicas, substâncias que figuram no Quadro I e no Quadro II anexos nesta Convenção, ou substâncias que tenham substituído as anteriormente mencionadas, saiam do território de um ou mais países, que o atravessem ou que nele ingressem, com o conhecimento e sob a supervisão de suas autoridades competentes, com o fim de identificar as pessoas envolvidas em praticar delitos especificados no parágrafo 1 do Artigo 3 desta Convenção".

\section{E no Artigo 11. Entrega Vigiada}

1 - Se os princípios fundamentais dos respectivos ordenamentos jurídicos internos o permitirem, as Partes adotarão as medidas necessárias, dentro de suas possibilidades, para que se possa recorrer, de forma adequada, no plano internacional, à entrega vigiada, com base nos acordos e ajustes mutuamente negociados, com a finalidade de descobrir as pessoas implicadas em delitos estabelecidos de acordo com o parágrafo 1 do Artigo 3 e de encetar ações legais contra estes.

2 - As decisões de recorrer à entrega vigiada serão adotadas, caso a caso, e poderão, quando necessário, levar em conta ajustes financeiros e entendimentos relativos ao exercício de sua competência pelas Partes interessadas.

3 - As remessas ilícitas, cuja entrega vigiada tenha sido negociada poderão, com o consentimento das Partes interessadas, ser interceptadas e autorizadas a prosseguir intactas ou tendo sido retirado ou subtraído, total ou parcialmente, os entorpecentes ou substâncias psicotrópicas que continham”. 
Assim, a Convenção de Viena não só definiu o que vem a ser entrega vigiada (alínea 1 do artigo $1^{\circ}$ ), como também traçou algumas regras básicas de sua utilização. Talvez por conta deste maior detalhamento (em relação ao convênio de Schengen) que a entrega vigiada ficou conhecida a partir deste Tratado Internacional.

Deve-se observar que a Convenção definiu a entrega vigiada como uma técnica. Técnica significa método, procedimento ${ }^{158-159}$. Portanto, a entrega vigiada vem a ser um método de investigação que busca a obtenção de provas capazes de identificar as pessoas envolvidas em praticar delitos especificados arrolados na Convenção de Viena ${ }^{160}$ e ligados ao tráfico de entorpecentes.

Além disso, a convenção traçou contornos para utilização da entrega vigiada apenas entre países, sem mencionar a possibilidade de utilização dentro de um mesmo Estado, como forma de combate ao tráfico de entorpecentes, vigiando a remessa ilícita de um ponto a outro dentro do país. O que não significa que os países signatários da convenção estejam proibidos de legislar as minúcias do procedimento da entrega vigiada, prevendo tal hipótese.

No Brasil, a Convenção de Viena foi aprovada pelo Decreto Legislativo $\mathrm{n}^{\mathrm{o}}$. 162, de 14.09.91 e incorporada ao ordenamento jurídico pátrio pelo Decreto $\mathrm{n}^{\mathrm{o}} .154$ de $26.06 .91^{161}$.

${ }^{158}$ Para Antonio Scarance Fernandes procedimento significa "a formação por atos que devam obedecer a uma sequência predeterminada pela lei, em que, após a prática de um ato, passa-se à do seguinte até o último da série, numa ordem a ser necessariamente observada" (FERNANDES, Antonio Scarance. Processo Penal Constitucional, $3^{\mathrm{a}}$ Edição, Ed. Revista dos Tribunais, p.64).

${ }^{159}$ Para Antonio Araldo Ferraz Dal Pozzo procedimento "vem a ser a disciplina legal da estrutura exterior de cada ato do processo, bem como da ordem em que eles devem se suceder" (DAL POZZO, Antonio Araldo Ferraz. Manual Básico de Direito Processual Civil. São Paulo: Editora Oliveira Mendes, 1998, p. 71).

${ }^{160}$ Pela Convenção de Viena são requisitos caracterizadores da entrega vigiada: 1 . necessidade de expressa previsão nas legislações internas; 2. existência de acordos internacionais que permitam a vigilância entre diversos países; 3. finalidade de descobrir pessoas e provas envolvidas na prática do delito de tráfico internacional de entorpecentes e coletar provas; 4 . as decisões que autorizarem a entrega vigiada devem ser analisadas de acordo com cada caso em concreto.

${ }^{161}$ O Presidente da República, usando da atribuição que lhe confere o art. 84, inciso IV da Constituição, e Considerando que a Convenção Contra o Tráfico Ilícito de Entorpecentes e Substâncias Psicotrópicas, foi concluída em Viena, a 20 de dezembro de 1988; Considerando que a referida convenção foi aprovada pelo Congresso Nacional, pelo Decreto Legislativo $\mathrm{n}^{\circ}$ 162, de 14 de junho de 1991; Considerando que a convenção ora promulgada entrou em vigor internacional em 11 de novembro de 1990, decreta: 
Vale ressaltar que a Convenção de Viena já adverte para a preocupação que deve existir em face dos princípios fundamentais dos respectivos ordenamentos jurídicos internos, justamente por condicionar a aplicação da entrega vigiada ao respeito aos princípios fundamentais dos países, pois em certas situações poderá haver afronta a tais princípios. Notadamente quando o texto aponta que as remessas vigiadas poderão ser interceptadas e autorizadas a prosseguir intactas ou tendo sido retirado ou subtraído, total ou parcialmente, os entorpecentes ou substâncias psicotrópicas que continham. Nessas circunstâncias, poderá se configurar afronta ao direito de intimidade, bem como do sigilo das comunicações, situações que serão tratadas oportunamente.

\subsubsection{Convenção Interamericana contra a fabricação e o tráfico ilícitos de armas de fogo, munições, explosivos e outros materiais correlatos - Washington de 14/11/1997 (CIFTA)}

A CIFTA- Convenção Interamericana contra a fabricação e o tráfico ilícito de armas - foi adotada pelos países da OEA em 1997, que se comprometeram a fortalecer a cooperação na questão da luta contra a fabricação e o tráfico ilícito de armamento no continente.

Participaram do encontro representantes de 22 (vinte e dois) países do continente, entre autoridades policiais, judiciais e militares, da Organização dos Estados Americanos (OEA) que, ao final, assinaram a Declaração de Bogotá.

O documento reitera a necessidade urgente de impedir, combater e erradicar a fabricação e o tráfico de armas de fogo, munições e explosivos, devido aos efeitos nocivos dessas atividades para a segurança de cada país e da região. A Declaração de Bogotá é

Art. $1^{\circ}$ A Convenção Contra o Tráfico Ilícito de Entorpecentes e Substâncias Psicotrópicas, apensa por cópia a este decreto, será executada e cumprida tão inteiramente como nela se contém.

Art. $2^{\circ}$ Este decreto entra em vigor na data prevista no parágrafo $2^{\circ}$ do artigo 29 da Convenção.

Brasília, 26 de junho de 1991; 170 da Independência e $103^{\circ}$ da República. Fernando Collor. Francisco Rezek. 
a manifestação da firme vontade política dos países do hemisfério em lutar contra o flagelo das $\operatorname{armas}^{162}$.

Durante o encontro, os participantes deliberaram priorizar certas situações, como a cooperação e o intercâmbio de experiências, assistência jurídica mútua, autorização para a expedição de licenças de importação e destruição de excedentes. Adotaram a ideia de atuarem em conjunto com organismos de inteligência para detecção das rotas e desmascaramento das máfias dedicadas a este delito.

Para controlar e rastrear as remessas ilícitas de armas, a CIFTA também inseriu a figura da entrega vigiada em seu texto, agora e pela primeira vez se referindo à aplicação desta técnica relacionada a objeto diverso de drogas e substâncias entorpecentes. Assim, foi a partir dessa Convenção que a entrega vigiada ganhou aplicabilidade fora de sua área originária, qual seja, de combate ao tráfico de entorpecentes.

O artigo $7^{\circ}$ da Convenção Interamericana contra a Fabricação e o Tráfico Ilícitos de Armas de Fogo, Munições, Explosivos e outros Materiais Correlatos (CIFTA), que trata da entrega vigiada, estabelece:

“7. Entrega vigiada: é a técnica que consiste em deixar que remessas ilícitas ou suspeitas de armas de fogo, munições, explosivos e outros materiais correlatos saiam do território de um ou mais Estados, os atravessem ou neles entrem, com o conhecimento e sob a supervisão de suas autoridades competentes, com o fim de identificar as pessoas envolvidas no cometimento de delitos mencionados no artigo IV desta Convenção.”

A CIFTA basicamente copiou a definição de entrega vigiada utilizada na Convenção de Viena, adaptando-a para ser utilizada no combate ao tráfico ilícito de armas e outros materiais correlatos. Todavia, trouxe a grande inovação de ampliar a utilização da técnica de obtenção de provas, deixando de lado a ideia de se tratar de um método apenas utilizado no combate às drogas.

${ }^{162}$ Horácio Serpa, embaixador da Colômbia na OEA, quem presidiu a primeira conferência da Cifta. 
No Brasil, a Convenção Interamericana contra a fabricação e o tráfico ilícitos de armas de fogo, munições, explosivos e outros materiais correlatos foi incorporada ao ordenamento jurídico pátrio pelo Decreto n ${ }^{\text {o }}$ 3.229, de 29.10.1999 ${ }^{163}$.

\subsubsection{Convenção das Nações Unidas contra o crime organizado transnacional (Convenção de Palermo) de 15/11/2000}

A Convenção de Palermo ${ }^{164}$, também conhecida como Convenção das Nações Unidas contra o Crime Organizado Transnacional, consiste numa estratégia internacional de enfrentamento ao crime. Tem por objetivo o redirecionamento das ações dos Estados e da comunidade internacional para o corte do fluxo financeiro das organizações criminosas. A promoção de mudança na cultura de prevenção e combate do crime organizado transnacional é uma das inovações da convenção, assim como eliminar incentivos para a comissão de novos delitos.

${ }^{163}$ O Presidente da República, no uso da atribuição que lhe confere o art. 84, inciso VIII, da Constituição, Considerando que a Convenção Interamericana contra a Fabricação e o Tráfico Ilícitos de Armas de Fogo, Munições, Explosivos e outros Materiais Correlatos foi concluída em Washington, em 14 de novembro de 1997; Considerando que o Congresso Nacional aprovou o Ato multilateral em epígrafe por meio do Decreto Legislativo $\mathrm{n}^{\mathrm{o}} 58$, de 18 de agosto de 1999; Considerando que o Ato em tela entrou em vigor internacional em $1^{\circ}$ de julho de 1998; Considerando que o Governo brasileiro depositou o Instrumento de Ratificação à referida Convenção em 28 de setembro de 1999, passando a mesma a vigorar, para o Brasil, em 28 de outubro de 1999, nos termos de seu art. XXV; decreta:

Art $1^{\circ}$ A Convenção Interamericana contra a Fabricação e o Tráfico Ilícitos de Armas de Fogo, Munições, Explosivos e outros Materiais Correlatos, concluída em Washington, em 14 de novembro de 1997, apensa por cópia a este Decreto, deverá ser executada e cumprida tão inteiramente como nela se contém.

Art $2^{\circ}$ Este Decreto entra em vigor na data de sua publicação.

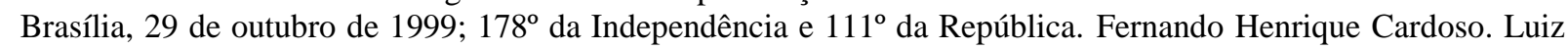
Felipe Lampreia.

${ }^{164}$ É de se mencionar que a Convenção de Palermo está em pleno uso, citando como exemplo sua utilização no caso da extradição do ex-banqueiro Salvatore Cacciola, preso no principado de Mônaco desde o dia 15 de setembro de 2007. A petição que o Brasil requereu sua extradição está enfatizada a Convenção de Palermo, tratado internacional firmado tanto pelo Brasil como por Mônaco. O documento prevê a colaboração mútua no sentido de combater atividades criminosas, com base na reciprocidade de tratamento. Como Brasil e Mônaco não têm acordo de extradição, a Convenção de Palermo embasa o pedido brasileiro. 
A Convenção de Palermo ${ }^{165}$, como convenção direcionada ao combate do crime organizado transnacional, é um dos instrumentos atuais mais avançados existentes no mundo jurídico-político, com especial destaque para as medidas de cooperação jurídica ou assistência jurídica mútua e confisco de bens.

Referido tratado foi ratificado pelo Brasil e em 12.03.2004 foi editado o Decreto 5.015/2004, que incorpora ao ordenamento jurídico brasileiro a "Convenção de Palermo" ou “Convenção das Nações Unidas contra o Crime Organizado Transnacional.

Além de trazer uma definição para "participação em grupo criminoso organizado", a Convenção de Palermo também aborda a "entrega vigiada", nos seguintes termos:

Entrega Vigiada ${ }^{166}$ "é a técnica que consiste em permitir que remessas ilícitas ou suspeitas saiam do território de um ou mais Estados, os atravessem ou neles entrem, com o conhecimento e sob o controle das suas autoridades competentes, com a finalidade de investigar infrações e identificar as pessoas envolvidas na sua prática”.

Entretanto, da mesma forma que a Convenção das Nações Unidas contra a Corrupção (que será exposta no item seguinte), a Convenção de Palermo aqui tratada também não especifica o objeto da remessa ilícita ou suspeita, como ocorre em relação a drogas (Convenção de Viena) e armas (Convenção Interamericana contra a Fabricação e o Tráfico Ilícitos de Armas de Fogo).

\footnotetext{
${ }^{165}$ Durante a Convenção de Palermo, o Ministério da Justiça do Brasil, representado pelo secretário nacional de Justiça, Romeu Tuma Júnior, ministrou palestra sobre cooperação jurídica internacional como meio de combate à criminalidade organizada transnacional. O Brasil foi o único país escolhido para expor suas experiências práticas em cooperação jurídica para os 147 países presentes na conferência.

${ }^{166}$ Expõe Rodrigo Carneiro Gomes, com relação a referida definição: "De plano, observa-se que a "entrega vigiada", muito mais do que uma técnica operacional e de combate ao crime organizado, é uma técnica de investigação de infrações, ou seja, o órgão do Estado com atribuições para seu uso como recurso eficiente contra ações de organizações criminosas deve ser o de investigação penal, sob a supervisão do Ministério Público e do Poder Judiciário, com agentes de investigação especialmente treinados para tal atividade" (GOMES, Rodrigo Carneiro. A novíssima lei de entorpecentes (Lei 11.343/2006) e as modificações da "ação controlada” ou "nãoatuação policial”. Revista de Doutrina da 4" Região, Porto Alegre, n. 16, fevereiro 2007. Disponível em < http://www.revistadoutrina.trf4.jus.br/artigos/edicao016/Rodrigo_Gomes.htm>).
} 
Vale ressaltar que a Convenção de Palermo traz a definição de grupo criminoso organizado ${ }^{167}$, na terminologia adotada internacionalmente. É a partir dessa definição que o Conselho Nacional de Justiça (CNJ), o Conselho da Justiça Federal (CJF) e o Tribunal Regional Federal da $4^{\text {a }}$ Região baixaram resoluções e recomendações fixando nova competência e especialização das varas no julgamento de ações empenhadas por organizações criminosas (Resolução 517 do CJF e Recomendação 3 do CNJ) ${ }^{168}$.

\subsubsection{Convenção das Nações Unidas contra a corrupção de 31/10/2003}

A Convenção das Nações Unidas contra a Corrupção entrou em vigor no dia 14 de dezembro de 2005. O documento assinado por mais de cem países, entre eles o Brasil, em 9 de dezembro de 2003, na cidade mexicana de Mérida, é o primeiro tratado global contra a corrupção. Em referência à assinatura da Convenção de Mérida, instituiu-se em 9 de dezembro o dia internacional contra a corrupção.

\footnotetext{
${ }^{167}$ Art. 2: "Para efeitos da presente Convenção entende-se por grupo criminoso organizado - grupo estruturado de três ou mais pessoas, existente há algum tempo e atuando concertadamente com o propósito de cometer uma ou mais infrações graves ou enunciadas na presente Convenção, com a intenção de obter, direta ou indiretamente, um benefício econômico ou outro benefício material".

${ }^{168}$ Consoante Rodrigo Carneiro Gomes: "Recentemente, a importância da Convenção de Palermo foi ressaltada, em 29.06.2006, pela proposta do Min. Gilson Dipp, do Superior Tribunal de Justiça, que, aprovada, alterou a Resolução $n^{\circ} .314$ do Conselho da Justiça Federal (CJF) para autorizar a especialização das varas criminais de lavagem de dinheiro também no processamento e julgamento de crimes praticados por organizações criminosas, adotando o conceito de crime organizado estabelecido na Convenção de Palermo"(Op. cit. p. 210).

Essas alterações foram consubstanciadas na Resolução nº. 517, de 30.06.2006, do CJF, publicada no Diário Oficial da União I no dia 06.07.2006, nos seguintes termos:

"Art. $1^{\circ}$ Os Tribunais Regionais Federais, na sua área de jurisdição, poderão especializar varas federais criminais com competência exclusiva ou concorrente para processar e julgar:

I - os crimes contra o sistema financeiro nacional e de lavagem ou ocultação de bens, direitos e valores; e

II - os crimes praticados por organizações criminosas, independentemente do caráter transnacional ou não das infrações.

Parágrafo único. Deverão ser adotados os conceitos previstos na Convenção das Nações Unidas contra o Crime Organizado Transnacional promulgada pelo Decreto nº. 5.015, de 12 de março de 2004."
} 
A Convenção de Mérida ${ }^{169}$ é um documento que oferece a estrutura legal para criminalizar práticas de corrupção, ampliar a cooperação internacional no enfrentamento de paraísos fiscais e facilitar a recuperação de ativos desviados para exterior.

Em junho de 2005, o Brasil ratificou, sem alterações, a Convenção das Nações Unidas contra a Corrupção. Foi o $26^{\circ}$ (vigésimo sexto) país a implementar as medidas de combate à corrupção previstas no documento.

Estatui o artigo $2^{\circ}$ da Convenção das Nações Unidas contra a Corrupção ${ }^{170}$ que "por entrega vigiada se entenderá a técnica consistente em permitir que remessas ilícitas ou suspeitas saiam do território de um ou mais Estados, o atravessem ou entrem nele, com o conhecimento e sob a supervisão de suas autoridades competentes, com o fim de investigar um delito e identificar as pessoas envolvidas em sua ocorrência”.

\subsubsection{Alguns pontos divergentes nas convenções}

\footnotetext{
${ }^{169}$ Segundo o texto, um combate eficaz à corrupção exige ação dos governos, da sociedade civil e do setor privado. Aos primeiros cabem realizar ações eficientes contra a corrupção, bem como implementar a Convenção. Aos demais, cabe dar apoio às ações governamentais e exigir que a administração pública seja mais transparente e aberta aos mecanismos de fiscalização e controle. A Convenção das Nações Unidas contra a Corrupção é o maior texto internacional juridicamente vinculante, ou seja, que obriga os Estados Partes que a ratificaram a cumprir os seus dispositivos, respeitados os princípios de soberania e direito interno de cada país. Compete à Controladoria-Geral da União (CGU), por meio da Secretaria de Prevenção da Corrupção e Informações Estratégicas, acompanhar a implementação das convenções e compromissos internacionais assumidos pelo Brasil, que tenham como objeto a prevenção e o combate à corrupção.

${ }^{170}$ O Presidente da República, no uso da atribuição que lhe confere o art. 84, inciso IV, da Constituição, e Considerando que o Congresso Nacional aprovou o texto da Convenção das Nações Unidas contra a Corrupção, por meio do Decreto Legislativo $\mathrm{n}^{\circ} 348$, de 18 de maio de 2005; Considerando que o Governo brasileiro ratificou a citada Convenção em 15 de junho de 2005; Considerando que a Convenção entrou em vigor internacional, bem como para o Brasil, em 14 de dezembro de 2005; decreta:

Art. $1^{\circ}$ A Convenção das Nações Unidas contra a Corrupção, adotada pela Assembléia-Geral das Nações Unidas em 31 de outubro de 2003 e assinada pelo Brasil em 9 de dezembro de 2003, apensa por cópia ao presente Decreto, será executada e cumprida tão inteiramente como nela se contém.

Art. $2^{\circ}$ São sujeitos à aprovação do Congresso Nacional quaisquer atos que possam resultar em revisão da referida Convenção ou que acarretem encargos ou compromissos gravosos ao patrimônio nacional, nos termos do art. 49, inciso I, da Constituição.

Art. $3^{\circ}$ Este Decreto entra em vigor na data de sua publicação.

Brasília, 31 de janeiro de 2006; $185^{\circ}$ da Independência e $118^{\circ}$ da República. Luiz Inácio Lula da Silva. Celso Luiz Nunes Amorim.
} 
Observa Carneiro ${ }^{171}$ que tal qual a Convenção de Palermo, a Convenção das Nações Unidas contra a Corrupção também não especifica qual o objeto relacionado ao que expressa como remessa ilícita ou suspeita, como ocorre em relação ao tráfico de entorpecentes (na Convenção de Viena) e armas (na Convenção Interamericana contra a Fabricação e o Tráfico Ilícitos de Armas de Fogo).

Conclui-se que a entrega vigiada ganhou contornos ainda mais genéricos, ante a ausência de objeto a ser vigiado. Isto é, a partir da Convenção de Palermo passa-se a autorizar a utilização da técnica de entrega vigiada para toda e qualquer remessa que seja ilícita ou suspeita, ligada, principalmente, às infrações praticadas pelo crime organizado.

Ao admitir tamanha extensão, sem definição específica do objeto ilícito a ser vigiado para desmantelar a quadrilha, a Convenção de Palermo abre um perigoso precedente na utilização deste meio de investigação. Isto porque suas regras e contornos legais deveriam estar traçados de forma precisa, para não haver abusos ou discricionariedades em sua utilização.

Neste mesmo sentido retratou Rodrigo Carneiro Gomes ${ }^{172}$ a seguinte diferença entre os tratados: ao contrário do que ocorre em relação à entrega vigiada ${ }^{173}$ quanto ao tráfico de drogas (Convenção de Viena de 1988 e Lei de Entorpecentes - Lei 11.403/2006) e à entrega vigiada quanto ao tráfico de armas (Convenção Interamericana contra a Fabricação e o Tráfico Ilícitos de Armas de Fogo, Munições, Explosivos e outros Materiais Correlatos CIFTA), a Convenção de Palermo e a Convenção das Nações Unidas contra a Corrupção não especificam qual o objeto da remessa ilícita ou suspeita, ou seja, não há determinação de um objeto específico que deva ter a remessa e o deslocamento controlado pelo órgão policial,

${ }^{171}$ GOMES, Rodrigo Carneiro. O Crime Organizado na Visão da Convenção de Palermo. Belo Horizonte: Editora Del Rey, 2009, p. 211.

${ }^{172}$ GOMES, Rodrigo Carneiro. A novíssima lei de entorpecentes (Lei 11.343/2006) e as modificações da "ação controlada" ou "não-atuação policial". Revista de Doutrina da $4^{a}$ Região, Porto Alegre, n. 16, fevereiro 2007. Disponível em < http://www.revistadoutrina.trf4.jus.br/artigos/edicao016/Rodrigo_Gomes.htm>.

${ }^{173} \mathrm{O}$ autor usa a expressão ação controlada, enquanto aqui se faz a adaptação para entrega vigiada. 
admitindo, implicitamente, que seja o mais amplo possível, desde que associado a práticas relacionadas ao crime organizado.

Outro ponto de grande divergência entre as Convenções que previram a figura da entrega vigiada refere-se à ausência de detalhamento normativo. Enquanto a Convenção de Viena de 1988 (aquela que de fato abriu o universo de conhecimento e aplicação da entrega vigiada) detalhou, de certa maneira, a utilização da entrega vigiada, expondo ao menos algumas regras básicas de sua aplicação (no artigo 11), as demais convenções apenas se concentraram em tão somente definir o que deveria ser entendido pela técnica da entrega vigiada, sem qualquer explicação sobre a sua forma de utilização e sistema de aplicação.

Significa dizer que o modelo de aplicação da entrega vigiada deve ser extraído, por analogia, da Convenção de Viena de 1988, já que as demais convenções apenas conceituaram a figura da entrega vigiada e mesmo assim copiando da definição que já fora exarada alhures na Convenção de Viena.

\subsection{A entrega vigiada no Brasil: há previsão legal?}

A Convenção de Viena, de 20 de dezembro de 1988, criada com a finalidade de combater o tráfico ilícito de drogas, previu, de forma expressa, o instituto da entrega vigiada, no artigo 1 , inciso de letra $1^{174}$.

A partir desta previsão, diversos países que aderiram e ratificaram a mencionada Convenção passaram a dispor sobre o instituto da entrega vigiada, adotando-a (também de forma expressa) em suas legislações internas, seja modificando em certos

${ }^{174}$ Artigo $1^{\circ}$, inciso 1: Por entrega Vigiada se entende a técnica de deixar que remessas ilícitas ou suspeitas de entorpecentes, substâncias psicotrópicas, substâncias que figuram no Quadro I e no Quadro II anexos nesta Convenção, ou substâncias que tenham substituído as anteriormente mencionadas, saiam do território de um ou mais países, que o atravessem ou que nele ingressem, com o conhecimento e sob a supervisão de suas autoridades competentes, com o fim de identificar pessoas envolvidas em praticar delitos especificados no parágrafo 1 do Artigo 2 desta Convenção. 
aspectos seu texto ou simplesmente adicionando ao seu ordenamento jurídico aquela figura da entrega vigiada, da mesma forma como prevista no texto normativo da Convenção.

Exemplo típico ocorreu na Espanha, que introduziu o artigo 263 bis no Título I, do Livro II, da Lei de Enjuiciamiento Criminal, passando a legislar expressamente sobre a entrega vigiada, bem como detalhando sua forma de utilização.

No Brasil há forte dissenso doutrinário acerca da existência ou não de previsão legislativa da entrega vigiada no ordenamento pátrio ${ }^{175}$. Assim, embora o Estado brasileiro tenha ratificado a Convenção de Viena e posteriores Convenções, como a de Palermo, nas quais existe a definição da técnica da entrega vigiada, fato é que se discute se há norma interna tratando do instituto, até porque, nenhuma das normas internamente existentes, ao menos nominalmente, faz referência à entrega vigiada.

Vale frisar que no capítulo anterior foi analisada a diferença entre a entrega vigiada e a ação controlada, que aqui tem especial relevância para a correta análise acerca da existência de previsão legal na lei pátria, porque as conclusões lá extraídas servirão de premissa para analisar a questão debatida neste tópico, qual seja: há previsão legal da entrega vigiada no Brasil?

Inicia-se do ponto de divergência: há quem sustente haver previsão expressa na lei brasileira da entrega vigiada ${ }^{176}$, apontando que sua previsão inicial se encontra na Lei de Tóxico $\mathrm{n}^{\mathrm{o}}$ 10.409/2002 (artigo 33) ${ }^{177}$, posteriormente substituída pela Lei $\mathrm{n}^{\mathrm{o}}$

\footnotetext{
${ }^{175}$ Marcelo Batlouni Mendroni defende que não há previsão da entrega vigiada em nosso ordenamento, dispondo: "Prevista no artigo 263 bis da Ley de Enjuiciamiento Criminal, a entrega vigiada trata-se de medida investigatória semelhante àquela da prática de agente infiltrado, embora com características pouco distintas. Enquanto o agente infiltrado se imiscui no âmbito, no seio da organização criminosa, a entrega vigiada é especialmente direcionada ao acompanhamento (monitoramento) da atividade criminosa, para melhor atingir o objetivo de identificação de outros participantes e do seu modus operandi. É o que, nos termos da atuação policial brasileira, poderíamos chamar de "ação monitorada", comumente utilizada pela Polícia, mas sem previsão legal." (MENDRONI, Marcelo Batlouni. Crime Organizado - Aspectos Gerais e mecanismos legais, Ed. Atlas, 2 ed., 2007).

${ }^{176}$ Conforme Damásio de Jesus e Vicente Greco Filho tal previsão existe e está contida na Lei de Drogas (Op. cit. pgs. 22 e 73).

${ }_{177}$ Previa o texto da revogada Lei $\mathrm{n}^{\circ}$ 10.409/2002: “Art. 33 - Em qualquer fase da persecução criminal relativa aos crimes previstos nesta Lei, são permitidos, além dos previstos na Lei 9.034, de 3 de maio de 1995, mediante autorização judicial, e ouvido o representante do Ministério Público, os seguintes procedimentos investigatórios:
} 
11.343/2006 (artigo 53) ${ }^{178}$, também conhecida como Nova Lei de Drogas. E que diante de tal previsão na Lei de Drogas passou-se a admitir a existência da previsão legal da entrega vigiada na legislação brasileira $^{179}$.

Em suma, surgiu uma corrente que defende que, a partir do advento da Lei de Drogas, mais precisamente no inciso II, do artigo 53, a entrega vigiada foi formalmente inserida na legislação interna ${ }^{180}$, ainda que sem titulação expressa de entrega vigiada. Significa

I - (...)

II - a não atuação policial sobre os portadores de produtos, substâncias ou drogas ilícitas que entrem no território brasileiro, dele saiam ou nele transitem, com a finalidade de, em colaboração ou não com outros países, identificar e responsabilizar maior número de integrantes de operações de tráfico e distribuição, sem prejuízo da ação penal cabível.

Parágrafo único. Na hipótese do inciso II, a autorização será concedida, desde que: I sejam conhecidos o itinerário provável e a identificação dos agentes do delito ou de colaboradores; II - as autoridades competentes dos países de origem ou de trânsito ofereçam garantia contra a fuga dos suspeitos ou de extravio dos produtos, substâncias ou drogas ilícitas transportadas."

${ }^{178}$ A Lei ${ }^{\circ} 11.343 / 2006$, que veio substituir o diploma de 10.409/2002, embora suprimiu a parte do texto que estendia a possibilidade de aplicação da técnica fora do país, praticamente transcreveu a previsão anterior, contemplando no artigo 53 e seus incisos os seguintes procedimentos investigatórios: "Artigo 53 - Em qualquer fase da persecução criminal relativa aos crimes previstos nesta Lei, são permitidos, além dos previstos em lei, mediante autorização judicial e ouvido o Ministério Público, os seguintes procedimentos investigatórios:

I - a infiltração de agentes de policia, em tarefas de investigação, constituída pelos órgãos especializados pertinentes;

II - a não-atuação policial sobre os portadores de drogas, seus precursores químicos ou outros produtos utilizados em sua produção, que se encontrem no território brasileiro, com a finalidade de identificar e responsabilizar maior número de integrantes de operações de tráfico e distribuição, sem prejuízo da ação penal cabível.

Parágrafo único - Na hipótese do inciso II deste artigo, a autorização será concedida desde que sejam conhecidos o itinerário provável e a identificação dos agentes do delito ou de colaboradores.".

${ }^{179}$ Mário Sérgio Sobrinho defende que a previsão contida no inciso II, da lei de drogas representa ação controlada. Para o autor: "No Brasil, a ação controlada foi inserida pelo art. $2^{\circ}$, II, da Lei 9.034/1995 e, em relação aos crimes previstos na Lei 11.343/2006, foi tratada pelo art. 53, II, e parágrafo único, desta lei, que estabeleceu normas para reprimir a produção não autorizada e o tráfico ilícito de drogas, definiu crimes e deu outras providências (Op. cit. p. 44).

${ }^{180}$ Damásio de Jesus admite a existência da previsão da entrega vigiada na legislação brasileira. Assevera referido autor que: "A entrega vigiada não era prevista em nossa legislação, que só admitia a ação controlada, consistente em retardar a interdição policial do que se supõe ação praticada por organizações criminosas (artigo $1^{\circ}$, inciso II, da Lei do Crime Organizado $n^{\circ}$ 9.034, de 3 de maio de 1995, alterada pela Lei ${ }^{\circ} 10.217$, de 11 de abril de 2001). Foi, contudo, prevista no artigo 33, inciso II, da Lei $\mathrm{n}^{\circ} 10.409$, de 11 de janeiro de 2002, que alterou a Lei Antitóxicos (Lei no 6.368/76)" (JESUS, Damásio de. Entrega Vigiada. São Paulo: Complexo Jurídico Damásio de Jesus, fev. 2002. Disponível em: <www.damasio.com.br〉). Também para Vicente Greco Filho não resta dúvida que a Lei de drogas introduziu o instituto da entrega vigiada no ordenamento jurídico pátrio. Para Greco: "Antes da Convenção de Palermo, a entrega vigiada era procedimento recomendado na Convenção de Viena sobre o Tráfico Ilícito de Entorpecentes de 1.988, promulgada pelo Decreto $\mathrm{n}^{\circ} 154$ de 26/06/91, mas não tinha correspondência na então Lei de Tóxicos, a Lei n ${ }^{\circ}$ 6.368/76. Em termos análogos há, ainda, a previsão do instituto na Convenção das Nações Unidas contra a corrupção (Decreto 5.687/2006) e na Convenção Interamericana Contra o tráfico de Armas (Decreto n ${ }^{\circ}$ 3.229/1999). No Brasil, a previsão encontra-se na lei $\mathrm{n}^{\circ}$ 11.343/2006 (Lei de Drogas)" (Op. cit. p. 4). Sérgio Ricardo de Souza também sustenta que o inciso II, do artigo 53, da lei de drogas traz a previsão da entrega vigiada (Nova Lei Antidrogas. Editora Impetus, Niterói, 2007, p. 144). 
dizer, assim, que o procedimento investigatório encartado no inciso II, do artigo 53, da Lei de drogas é tido por parte da doutrina como a técnica definida de entrega vigiada.

A corrente divergente, que sustenta não haver previsão da entrega vigiada na legislação brasileira ${ }^{181}$, aponta que este artigo II, do artigo 53, da Lei $\mathrm{n}^{\circ}$ 11.343/06, nada mais representa do que o tratamento legal da técnica denominada ação controlada ou algo muito assemelhado a tal técnica (referida na lei do crime organizado).

Assim, para solucionar a questão lançada neste tópico, forçoso responder: o instituto previsto no artigo 53, inciso II da Lei de Drogas se refere à ação controlada ou à entrega vigiada? E mais, mesmo que os diversos autores ora denominem como ação controlada, ora como entrega vigiada, o que essa técnica do supracitado artigo representa em sua essência?

Para responder tal questão e verificar a qual corrente assiste razão, faz-se crucial a verificação da previsão contida no artigo 53, inciso II, da nova lei de Tóxicos, cotejando-a com o instituto da ação controlada (Lei $n^{\circ}$ 9.034/95) e da entrega vigiada, para verificar com qual instituto aquela previsão se iguala ou, ao menos se assemelha. E, ao final, com as conclusões comparativas, verificar se há previsão da entrega vigiada na legislação brasileira ou se o procedimento previsto na Lei de Drogas não passa do conhecido instituto da ação controlada.

Destacam-se, assim, os elementos característicos de cada instituto, para que se percebam suas semelhanças e diferenças.

A redação prevista na Lei de Drogas ${ }^{182}$ : a) tem como verbo central "a não atuação policial"183; b) tem previsão de aplicação apenas no âmbito interno; c) refere-se tão

${ }^{181}$ Ver Marcelo Mendroni, Eduardo Araujo da Silva, dentre outros.

${ }^{182}$ Segundo Rodrigo Carneiro Gomes (op. cit. p.59), possui esta nova lei alguns traços peculiares: "imprescinde de autorização judicial; depende de prévia oitiva do representante do Ministério Público; repressão de crime de tráfico de drogas e outros reprimidos pela Lei 11.343/2006; não-atuação policial permitida em lei; aplicação na repressão contra portadores de drogas, seus precursores químicos ou outros produtos utilizados em sua produção; exige que o objeto do delito e autores se encontrem no território brasileiro (não necessariamente todos os 
somente aos ilícitos relacionados a (portadores de) drogas; d) tem por agente a polícia; e) prevê a necessidade de autorização judicial.

A ação controlada, segundo o mesmo raciocínio, tem como características: a) "retardar ação policial"; b) tem previsão de aplicação também apenas no âmbito interno; c) refere-se aos ilícitos relacionados com ação praticada por organizações criminosas ou a ela vinculada; d) tem por agente a polícia; e) não requer a autorização judicial $^{184}$.

Por fim, a entrega vigiada: a) tem como verbo central "deixar que remessas ilícitas ou suspeitas transitem"; b) tem aplicabilidade tanto no âmbito interno, como também internacional; c) refere-se a ilícitos de objetos variados (drogas, armas etc); d) faz referência a vigilância por autoridades competentes, o que significa dizer que não é realizada obrigatoriamente apenas por policiais; e) entende-se necessária a autorização judicial ou de outra autoridade tida como competente, que a legislação venha a apontar.

integrantes do grupo de traficantes ou da organização criminosa); finalidade de identificar e responsabilizar maior número de integrantes de operações de tráfico e distribuição, sem prejuízo da ação penal cabível; autorização mediante conhecimento do itinerário provável e a identificação dos agentes do delito ou de colaboradores".

${ }^{183} \mathrm{Na}$ revogada Lei no $10.409 / 2002$, assim como na atual Lei no $11.343 / 2006$, não há menção expressa à "entrega controlada" ou "ação vigiada". O legislador preferiu a terminologia "não atuação policial" a fim de identificar e responsabilizar maior número de integrantes de operações de tráfico e distribuição, sem adentrar na polêmica caracterização dos traficantes em atuação na forma de associação para tráfico, quadrilha/bando ou organização criminosa. A terminologia "ação controlada", em termos de técnica operativa-policial é mais abrangente e representa melhor a ideia do trabalho de acompanhamento, vigilância e investigação policial, pois não se trata apenas de "não-atuação policial". Outra vantagem da terminologia "ação controlada" é que a mesma carrega o conceito de "controle" de ações de associações, quadrilhas e organizações criminosas que são voltadas para o tráfico de drogas, seus precursores químicos, como também de armas, contrabando e propina. (GOMES, Rodrigo Carneiro. Op. Cit. p. 214).

${ }^{184}$ A Lei no 9.034/95 não exige prévia autorização judicial para a adoção da ação controlada, mas tão-somente dois requisitos: (1) a existência de um crime em desenvolvimento praticado por organização criminosa ou a ela vinculado; (2) a observação e acompanhamento dos atos praticados pelos investigados até o momento mais adequado para a formação da prova e a colheita de informações. A Lei n ${ }^{\circ} 11.343 / 06$, contrariamente, prevê que a adoção do instituto deverá ser precedida de autorização judicial, após a oitiva do representante do Ministério Público (art. 53, caput). Outrossim, exige como requisito "sejam conhecidos o itinerário provável e a identificação dos agentes do delito ou de colaboradores (art. 53, parágrafo único). Mário Sérgio Sobrinho defende que a previsão contida no inciso II, da lei de drogas representa ação controlada. Para o autor: "No Brasil, a ação controlada foi inserida pelo art. $2^{\circ}$, II, da Lei 9.034/1995 e, em relação aos crimes previstos na Lei 11.343/2006, foi tratada pelo art. 53, II, e parágrafo único, desta lei, que estabeleceu normas para reprimir a produção não autorizada e o tráfico ilícito de drogas, definiu crimes e deu outras providências". (Op. cit. p. 44). 
Diante da apresentação comparativa dos elementos componentes dos institutos em exame, percebe-se que o procedimento investigatório da Lei de droga, previsto no artigo 33, inciso II, da Lei $n^{\circ}$ 10.409/2002 reproduzido similarmente no artigo 53, inciso II pela Lei $\mathrm{n}^{\mathrm{o}}$ 11.343/2006 (que veio a substituir o diploma de 2002), guarda profunda semelhança com a ação controlada da lei do crime organizado, excepcionando-se alguns pequenos pontos.

A não atuação policial, consoante disposto na Lei de Drogas significa, em última análise, o mesmo escopo ${ }^{185}$ da previsão da ação controlada do artigo $2^{\circ}$ da lei 9.043/95, uma vez que ambas admitem a possibilidade de retardar a interdição policial para aguardar o melhor momento de intervenção na ação delituosa. Além disso, ambas têm aplicabilidade apenas internamente e as duas técnicas prevêem policias para execução de suas medidas.

Portanto, a previsão estampada no inciso II, do artigo 53, da Lei de Drogas guarda maior semelhança com a redação da ação controlada, do artigo $2^{\circ}$ da lei do crime organizado, do que com a redação definidora da entrega vigiada contida nas convenções internacionais assinadas e ratificadas pelo Brasil. De forma que, se tivesse que definir o instituto da lei de drogas, cuja norma não lhe atribuiu sua denominação, o mais prudente seria entendê-la como ação controlada ${ }^{186}$.

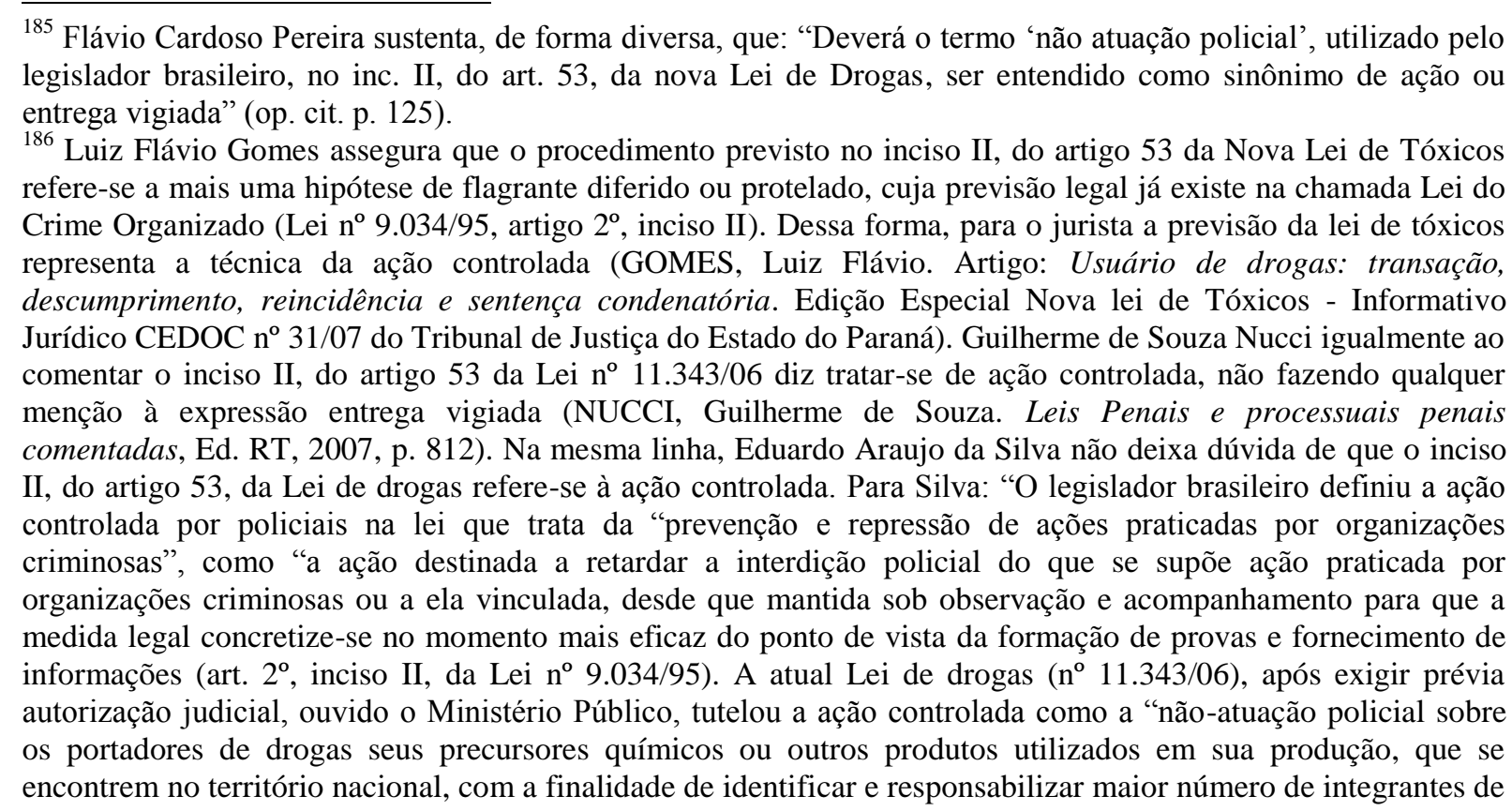


De se concluir que a Lei de Drogas não trata da previsão do instituto da entrega vigiada. E mais, como não trata da entrega vigiada, não se vislumbra previsão normativa dessa técnica no ordenamento pátrio, porque naquela legislação seria a única previsão possível da existência do instituto no ordenamento jurídico interno.

operações de tráfico e distribuição, sem prejuízo da ação penal cabível (inciso II do art.53) (DA SILVA, Eduardo Araujo. Op. cit. p.82). Ainda optando por definir a previsão da lei de drogas como ação controlada, Rodrigo Carneiro Gomes deixa assente de dúvida sua opinião: "Encontra-se em vigor desde o mês de outubro de 2006, a novíssima lei de entorpecentes que revogou a Lei 10.409/2002, com novas disposições sobre a "ação controlada" ou "não interdição policial", na terminologia da lei. A nova Lei 11.343/2006 traz como novidade que a "nãoatuação policial", ou melhor, a ação controlada, poderá ser executada também para identificação de portadores dos precursores químicos" (GOMES, Rodrigo Carneiro. O crime organizado na visão da convenção de Palermo. $2^{\mathrm{a}}$ ed. Del Rey Editora. Belo Horizonte: 2009, p. 206). 


\section{CAPÍTULO III}

\section{ENTREGA VIGIADA: CONCEITO, CARACTERÍSTICAS E PECULIARIDADES}

\subsection{Conceito de entrega vigiada}

Entrega vigiada ${ }^{187}$ é a técnica de investigação consistente em permitir que remessas ilícitas ou suspeitas de entorpecentes ou outras substâncias proibidas circulem pelo território nacional, bem como dele saiam ou nele ingressem, sem interferência impeditiva da autoridade ou seus agentes, mas sob sua vigilância. Tudo com o fim de descobrir ou identificar as pessoas envolvidas ${ }^{188}$ no cometimento de algum delito de elevada gravidade, bem como prestar auxílio a autoridades estrangeiras nesses mesmos fins.

Victor Roberto Prado Saldarriaga ${ }^{189}$ conceitua a entrega vigiada ${ }^{190}$ da seguinte maneira: "a técnica especial de investigação que permite que uma remessa de drogas,

\footnotetext{
${ }^{187}$ Para Rodrigo Gomes Carneiro: “A entrega vigiada, muito mais do que uma técnica operacional e de combate ao crime organizado, é uma técnica de investigação de infrações, ou seja, o órgão do Estado com atribuições para seu uso como recurso eficiente contra ações de organizações criminosas deve ser o de investigação penal, sob a supervisão do Ministério Público e do Poder Judiciário, com agentes especialmente treinados para tal atividade, o que, inevitavelmente, leva à conclusão de que deva ser exercida pela Polícia Judiciária". Prossegue o autor: "A razão de ser do instituto é a enorme dificuldade encontrada pelos investigadores para identificar o destinatário da droga e demonstrar seu dolo, especialmente, se a droga descoberta foi abandonada, perdida ou não reclamada, por exemplo, em caso de passageiro de ônibus ou avião que "esquece" a bagagem no terminal de desembarque, para que outro a encontre propositadamente". (GOMES, Rodrigo Carneiro. Investigação Criminal na Convenção de Palermo: Instrumento e Limites. In: Limites Constitucionais da Investigação. São Paulo: RT, 2009, p. 373).

${ }^{188}$ Esse é o posicionamento de Flávio Cardoso Pereira: "Na entrega vigiada prevista na Lei 11.343/2006 (nova Lei de drogas), em seu art. 53, II, permite-se na maioria das vezes que não sejam tão-somente identificados os 'mulas' dentro do tráfico de drogas, possibilitando-se a identificação e posterior detenção também dos eventuais compradores da droga quem normalmente, são os traficantes da mesma" (PEREIRA, Flávio Cardoso. A moderna investigação criminal. In: Limites...p. 122).

189 SALDARRIAGA, Victor Roberto Prado. La Entrega Vigilada: orígenes y desarrollos, in 〈http://www.unifr.ch/derechopenal/articulos/pdf/02septiembre06/entregavigilada_prado.pdf >. No texto foi apresentada tradução livre do seguinte trecho original: "la técnica especial de investigación que permite que una remesa de drogas, armas, insumos químicos o cualquier otra especie de procedencia o tráfico ilegal, y que se envía ocultamente, pueda llegar a su lugar de destino sin ser interceptada por las autoridades competentes, a fin de individualizar a los remitentes, a los destinatarios, así como a los demás involucrados en dicha actividad ilícita."
} 
armas, insumos químicos ou qualquer outra espécie de procedência ou tráfico ilegal e que se envia ocultamente, pode chegar a seu local de destino, sem ser interceptada pelas autoridades competentes, a fim de individualizar seus remetentes, seus destinatários, assim como os demais envolvidos em dita atividade ilícita".

A entrega vigiada, segundo Mario Daniel Montoya"191, é "um procedimento levado a cabo pelas autoridades que, ao descobrir substâncias entorpecentes que são transportadas através de diversos meios, procede ao seu controle a fim de determinar de forma encoberta quem participa do delito, as modalidades do mesmo, rota a seguir, contatos, dados do remetente e do destinatário e de todos aqueles que possam participar desta manobra ilícita a fim de chegar aos níveis mais altos de uma organização delitiva”.

\section{Carlos Enrique Edwards ${ }^{192}$ define entrega vigiada ${ }^{193}$ como "uma técnica} investigativa pela qual a autoridade judicial permite que um carregamento de entorpecentes, que se envia ocultamente através de qualquer meio de transporte pode chegar ao seu local de destino sem ser interceptada, a fim de individualizar o remetente, destinatário e demais participantes de tal manobra delitiva".

\footnotetext{
${ }^{190}$ Na definição de Sergio Ricardo de Souza “a entrega vigiada ou 'repasse controlado' consiste em autorizar que os policiais deixem de agir ou de atuar quando se deparem com situações em que havendo suspeitas de que pessoas sejam portadoras de drogas, seus precursores químicos ou outros produtos utilizados em sua produção com vistas a propiciar o descobrimento e responsabilização de outros envolvidos, ou seja, autoriza a que nessas situações a Polícia, por meio das autoridades policiais ou de seus agentes, deixe de autuar em flagrante o suspeito e apreender as drogas, com a finalidade de identificar e responsabilizar as demais pessoas envolvidas na respectiva operação de tráfico e distribuição" (SOUZA, Sergio Ricardo de. A Nova Lei Antidrogas. Editora Impetus, $2^{a}$ edição, pág. 144).

${ }^{191}$ MONTOYA, Mario Daniel. Informantes y Técnicas de Investigación Encubiertas. Análises Constitucional y Procesal Penal, $2^{\mathrm{a}}$ edição, Editora Ad Hoc, Buenos Aires. Tradução livre.

${ }^{192}$ EDWARDS, Carlos Enrique. El arrepentido, el agente encubierto y la entrega vigilada. Modificación a la Ley de Estupefacientes. Análisis de la ley 24.424, Editora Ad Hoc, Buenos Aires. No texto foi apresentada tradução livre do seguinte trecho original: "una técnica investigativa por la cual la autoridad judicial permite que un cargamento de estupefacientes, que se envía ocultamente a través de cualquier medio de transporte pode llegar a su lugar de destino sin ser interceptada, a fin de individualizar al remitente, destinatario y demás participes de esta maniobra delictiva".

${ }^{193}$ Damásio de Jesus adotou o conceito acima mencionado de Carlos Enrique Edwards, apenas traduzindo-o em seu artigo, quando afirmou que entrega vigiada pode ser definida como "uma técnica de investigação pela qual a autoridade judicial permite que um carregamento de entorpecentes enviado ocultamente em qualquer tipo de transporte possa chegar ao seu destino sem ser interceptado, a fim de se poder identificar o remetente, o destinatário e os demais participantes dessa manobra criminosa" (JESUS, Damásio de. Entrega Vigiada. São Paulo: Complexo Jurídico Damásio de Jesus, fev. 2002. Disponível em: <www.damasio.com.br〉).
} 
Trata-se, portanto, de um meio de investigação ou também chamado de técnica ou método de investigação, cujo escopo é o de permitir que remessas ilícitas ou suspeitas (sejam de drogas, substâncias entorpecentes, armas ou outros objetos da atividade criminosa - embora a maioria dos conceitos mencione especialmente drogas) circulem no interior de um Estado ou saiam do território de mais de um Estado, os atravessem ou neles entrem, mas sempre de forma monitorada, com o conhecimento e sob o controle das autoridades competentes, para melhor atingir o objetivo de identificação do maior número possível de agentes participantes envolvidos na sua prática, bem como desvendar seu modus operandi. Consiste, por consequência, em meio de obtenção de provas, que serão alcançadas e recolhidas com o resultado do emprego da entrega vigiada.

Este meio de investigação ganhou esta nomenclatura por denotar fielmente aquilo que representa, ou seja, entrega vigiada porque as remessas ilícitas são monitoradas do ponto de partida até seu recebimento, com identificação dos agentes envolvidos na prática criminosa. Todavia, tal vigilância não tem a simples e isolada intenção de acompanhar a entrega da remessa ilícita ao seu destino, mas sim de desvendar sua rota, seu modo de operação e os líderes envolvidos na criminalidade organizada.

A entrega vigiada permite o controle do trânsito de objetos ilícitos entre diversos países, pressupondo a existência de acordos e tratados entre eles, procurando obter informações sobre a forma de agir e quem são os agentes e colaboradores do crime organizado. Por isso, além de meio de investigação especial é considerada também como instrumento de cooperação entre Estados em face à criminalidade organizada.

O conceito utilizado pelos países que já adotaram uma legislação sobre o tema advém, basicamente, da definição encartada no artigo $1^{\circ}$, inciso 1 , da Convenção de Viena de $1988^{194}$. Mesmo aqueles países que não têm legislação específica, mas contêm em

194 A Convenção de Viena de 1988, conhecida também como a Convenção contra o tráfico ilícito de entorpecentes e de substâncias psicotrópicas, definiu a entrega vigiada no artigo $1^{\circ}$, inciso 1 , da seguinte maneira: "Por entrega vigiada se entende a técnica de deixar que remessas ilícitas ou suspeitas de entorpecentes, substâncias psicotrópicas, substâncias que figuram no Quadro I e no Quadro II anexos nesta Convenção, ou substâncias que tenham substituído as anteriormente mencionadas, saiam do território de um ou mais países, que o atravessem ou que nele ingressem, com o conhecimento e sob a supervisão de suas autoridades competentes, 
suas normas apenas a menção a esta técnica utilizam-se por analogia, da referência prevista na Convenção.

\subsection{Objetivo da entrega vigiada}

A entrega vigiada tem como finalidade ${ }^{195}$ precípua a obtenção de significativos elementos de prova incriminadores contra os responsáveis da organização criminosa e, sobretudo, a intenção de penetrar profundamente nesta organização dedicada ao cometimento de delitos, para individualizar seus integrantes.

Visa à descoberta de crimes relacionados ao tráfico internacional de entorpecentes ou outros objetos ilícitos, bem como ao desmantelamento da rede criminosa, descobrindo a forma de ação desses agentes.

A doutrina estrangeira ${ }^{196}$ assevera que: "a finalidade desta forma de investigação é que permite conhecer e deter todos os integrantes da rede de narcotraficantes, ao mesmo tempo em que assegura uma maior eficácia investigativa, já que ao se interceptar a remessa de entorpecentes antes de chegar ao seu destino, ignorar-se-á quem será seu destinatário ou, conhecendo-o, não se poderá incriminá-lo. Tem, assim, o objetivo de controlar seu traslado e de identificar e colocar à disposição da justiça os indivíduos, sociedades ou

com o fim de identificar pessoas envolvidas em praticar delitos especificados no parágrafo 1, do Artigo 2, desta Convenção".

${ }^{195}$ Para Gumersindo Guinarte Cabada: "la finalidad perseguida con la autorización de la entrega o circulación vigilada se ala de identificar o descubrir a los presuntos responsables penales de determinadas conductas delictivas. A diferencia de la norma italiana del artículo 98 del Texto único, el artículo 263 bis de la Ley de enjuiciamiento Criminal, no alude expresamente a la finalidad de descubrir a los responsables de estos delitos ha de concretarse necesariamente, desde una perspectiva procesal, en la obtención de elementos de prueba que, como tales, puedan ser aportados en el juicio penal" (CABADA, Gumersindo Guinarte. La Circulación o entrega vigilada de drogas. Cuadernos de política criminal. Edersa Editoriales, 1995. Madrid, p.16).

${ }^{196}$ Segundo Mario Daniel Montoya, "a entrega vigiada tem por finalidade levar a cabo a persecução da atividade criminal a fim de adquirir elementos significativos de prova incriminadoras com relação aos responsáveis e, sobretudo, penetrar mais profundamente na organização dedicada ao delito e identificar seus integrantes". Tradução livre do seguinte trecho original "llevar a cabo la persecución de la actividad criminal a fin de adquirir significativos elementos de prueba incriminatorios para los responsables y sobre todo penetrar más profundamente en una organización dedicada al delito e individualizar a los integrantes de sus cúspides". Op. cit. p. 156. 
outras entidades jurídicas que tiverem participado de seu envio, transporte, entrega, ocultação e recepção ${ }^{197,}$.

A figura da entrega vigiada é resultado da conscientização das Nações de que o tráfico de entorpecentes ou outras ações criminosas não se afiguram um problema interno ou regional, mas, ao contrário, possuem tentáculos espalhados por diversos países, os quais ocupam posições diferentes no contexto da rede de narcotráfico, classificados, embora não exclusivamente, como países produtores (principalmente de drogas naturais), países de rota ou de trânsito e países consumidores.

O escopo dessa forma de investigação é permitir que todos os integrantes da rede de narcotraficantes ou de uma organização criminosa sejam identificados e devidamente punidos, com extinção dessa estrutura delituosa.

Além disso, objetiva esta técnica garantir maior eficiência na investigação, pois, quando a remessa ilícita é interceptada antes de chegar ao seu destino, ignora-se quem é o destinatário ou, mesmo que ele seja conhecido, não pode ser incriminado.

Assim, por meio da técnica investigativa referida, se almeja, em última análise, o combate à criminalidade organizada de forma a extirpar suas raízes e não apenas seus diversos focos isolados de atuação.

Regra geral, o tratamento legislativo da entrega vigiada, conferido pelos ordenamentos de diversos países e das convenções que tratam do assunto, apontam que sua finalidade consiste na identificação e responsabilização de todos os membros da organização criminosa envolvidos com operações de tráfico e outros objetos ilícitos. Todavia, alguns países

${ }^{197}$ EDWARDS, Carlos Enrique. El Arrepentido, el agente encubierto y la entrega vigilada. Editora Ad Hoc, Buenos Aires, pág. 107. No texto foi apresentada tradução livre do seguinte trecho original: "la finalidad de esta forma de investigación es que permite conocer y detener a todos los integrantes de la red de narcotraficantes; a su vez, asegura una maior eficacia investigativa, ya que si se intercepta la remesa de estupefacientes antes de llegar a destino, se ignorará quién es el destinatario, o conociéndolo, no se lo podrá incriminar. Tiene así el objeto de controlar su traslado y de identificar y poner a disposición de la justicia a los individuos, sociedades u otras entidades jurídicas que hayan participado en su envio, transporte, entrega, ocultación e recepción". 
costumam mencionar, ainda, como complemento, que a finalidade da entrega pode consistir no auxílio a autoridades estrangeiras com o mesmo objeto.

Trata-se da mesma finalidade, embora vista sob ângulos diversos. Dessa maneira, por exemplo, um País intermediário, que não seja o Estado de origem nem de destino da mercadoria, não teria por finalidade primeira a responsabilização dos agentes envolvidos na operação, cuja remessa tramitará por seu País, apenas de passagem, entre a origem e o destino. Nesse caso, seu objetivo principal é o de auxiliar o País que vem investigando a circulação e que do País intermediário se socorre para lograr êxito no desbaratamento da quadrilha.

Esta finalidade da entrega, referente ao auxílio às autoridades estrangeiras, busca, na verdade, facilitar a identificação e o descobrimento de pessoas envolvidas nos delitos não para sua persecução no país auxiliador (pelo menos não de forma exclusiva) senão em outros países.

Sérgio Ricardo de Souza ${ }^{198}$ abordou este aspecto da entrega vigiada como instrumento de auxílio internacional, lembrando que "a utilização dos mecanismos que envolvem a entrega vigiada, apesar de significarem mais um exemplo de redução da ideia tradicional de soberania individual das nações, por certo pode contribuir para a implementação de uma política internacional mais eficaz de combate ao narcotráfico. E tal não se constitui em ação isolada do legislador brasileiro, estando presente em diversas outras legislações, as quais visavam propiciar a identificação e prisão não só dos eventuais transportadores, mas dos produtores, financiadores e líderes das gangues de narcotraficantes”.

\subsection{Natureza jurídica}

No estudo de qualquer instituto jurídico, o desvendar de sua natureza jurídica auxilia, sobremaneira, a sua compreensão. Isto porque a partir de tal descoberta, fica

\footnotetext{
${ }^{198}$ SOUZA, Sergio Ricardo de. A Nova Lei Antidrogas. Editora Impetus, $2^{\text {a }}$ edição, pág. 145.
} 
mais simples enquadrar e classificar o instituto em alguma categoria jurídica já existente e que com ele possui características comuns. Com a entrega vigiada isso não é diferente.

Pode-se afirmar que a natureza jurídica da entrega vigiada é a de um método, uma técnica ou um meio de investigação, em algumas situações de utilização excepcional, notadamente para o enfrentamento da criminalidade organizada, traduzida, ainda, em um meio de obtenção ${ }^{199}$ de prova, como resultado de sua aplicação.

A entrega vigiada, a rigor, não é meio de (produção de) prova, mas sim meio de obtenção de prova, podendo dar origem a provas testemunhais, documentais ou ainda resultar na apreensão de coisas factíveis de serem tidas como corpo de delito.

Em resumo, a entrega vigiada é um meio de investigação para conseguimento da prova e, como tal, possui características próprias dessa classificação, em especial: a) refere-se a procedimento de obtenção de provas, em geral extraprocessual; b) pode ser produzido pelo juiz, pelo Ministério Público e, em algumas hipóteses, pela polícia judiciária durante a fase de investigação; c) baseia-se no fator surpresa e, portanto, não prevê a comunicação do defensor do investigado quando a técnica for utilizada na fase de investigação; d) por essa cautelaridade, configurada pela surpresa, recai sobre fatos que por sua fugacidade, dificilmente são reproduzidos em juízo; e) por seu intermédio recolhem-se elementos probatórios preexistentes ao procedimento de sua aquisição para o processo; f) o vício em sua obtenção ocasiona a inadmissibilidade da prova no processo.

Mas, não só isso. Com relação à natureza jurídica do instituto em questão não basta classificar a entrega vigiada como um meio de investigação e de obtenção da prova. Para sua aprofundada classificação faz-se necessário ir além e categorizá-la dentro do gênero da vigilância, do monitoramento. Não é de hoje que a ação de vigiar, fazer "campana",

${ }^{199}$ Neste sentido Guillermo J. Yacobucci: "la autoridad judicial puede, mediante decreto fundado, retardar (pero no imitir) la emisión de ordenes de captura (arresto) o secuestro cuando ello sea necesario para adquirir medios de prueba relevantes o también para proceder a la individualización o a la captura de los responsables del delito de tráfico de estupefacientes o del delito de asociación destinada al tráfico de dichas substancias" (El Crimen Organizado, desafíos y perspectivas en el marco de la globalización, editorial ábaco de Rodolfo Depalma, Ciudad de Buenos Aires. 
acompanhar uma atividade que se desconfia ilícita, são procedimentos utilizados na praxis da persecução criminal. Todavia, no caso em exame, trata-se de vigilância de um crime em andamento. Assim, com relação à técnica da entrega vigiada, o aspecto da vigilância tem traço um pouco distinto, porque se monitora uma atuação delitiva em execução, devidamente autorizada.

A vigilância é coisa comum no cotidiano da polícia, seja nas diligências mais simples (como no ato diário de abordar um sujeito suspeito) ou naquelas que dependem de maior complexidade. Mas, sempre como ato de prevenção ou controle de delitos ou, até mesmo, para flagrar o delito que está na iminência de ser cometido.

Por um lado, a vigilância e o monitoramento podem contribuir na solução de questões criminais, em especial na persecução de organizações criminosas. De outro, a vigilância, quando utilizada fora dos objetivos ordinários legalmente admissíveis, possivelmente afrontará direito fundamental.

$\mathrm{Na}$ atuação de vigilância da polícia, Francis Rafael Beck observa que: “O 'combate preventivo ao crime' como objetivo da atividade policial acaba por aplainar os limites entre prevenção e repressão, entre prevenção de perigos e combate ao crime que, até então, separaram nitidamente os domínios policial e processual penal. Métodos de investigação, tais como a escuta telefônica, observação policial, apurações secretas e captação de dados estendem-se, em regra, a terceiros não partícipes, até então uma nítida exceção. A frequente inclusão nas investigações dos chamados 'elementos de contato' visa essa intromissão. Todos esses meios são utilizados nas costas do atingido, sub-repticiamente: até o presente as investigações eram por princípio abertas, a fim de que o atingido pudesse, desde logo, cuidar da sua defesa. As chamadas 'pré-investigações' removem os limites de intervenção delineados pela noção de indício, que tradicionalmente serviu para legitimar transtornos na vida de pessoas inocentes, somente aceitáveis mediante pressupostos e balizas 
claros. A pena patrimonial transfere doravante para o atingido o encargo de provar a decência de seus ganhos 200 ,

\subsection{Entrega vigiada como meio de prova atípica}

\section{A técnica investigativa denominada entrega vigiada é uma forma de} obtenção de prova atípica ${ }^{201}$, porquanto não está prevista em lei ou, ainda que admitida sua previsão, não tem procedimento legalmente delimitado para seu efetivo emprego.

${ }^{200}$ BECK, Francis Rafael. Perspectivas de controle ao crime organizado e crítica à flexibilização das garantias. Monografia IBCCRIM, p.109.

${ }^{201}$ Na XX Jornada de Málaga foram elaborados e discutidos diversos relatórios pelos países participantes e que teve a participação de renomados representantes brasileiros discutindo a questão da prova atípica. $\mathrm{O}$ relator do Paraguai, Rodolfo Duarte Pedro, afirma que "é requisito indispensável a licitude do meio de prova e a técnica para sua obtenção". No artigo 209 do Código de Processo Penal de Buenos Aires consta que outros meios de prova serão admitidos quando não suprimam as garantias individuais das pessoas e não afetem o sistema constitucional, e, segundo o Código de Processo Penal de La Nación, quando não vulnerem as garantias constitucionais. No artigo 234 do Código de Processo Penal da Costa Rica, afirma-se que, além dos meios de prova previstos naquele código, poderão ser utilizados outros distintos, sempre que não suprimam as garantias e faculdades das pessoas, nem afetem o sistema institucional. A prova é ilícita, segundo a maioria dos relatórios dos países, quando realizada com ofensa a normas constitucionais sobre direitos e garantias fundamentais ou a regras proibitivas. Segundo magistério de Ada Pellegrini Grinover, baseado em posição de Nuvolone, referido pelos relatores brasileiros, drs. Antonio Magalhães Gomes Filho e Gustavo Henrique Righi Ivahy Badaró, a prova ilícita é a que ofende norma material. Cita a relatora colombiana o dr. Jairo Parro Quijano que define como prova ilícita a que "se obtém violando os direitos fundamentais das pessoas", podendo a violação ter sido feita "para lograr a fonte de prova ou o meio probatório". Problema diverso é o da admissibilidade da prova e que se coloca no plano processual. Consiste em saber se uma prova, lícita ou ilícita, pode ser acolhida no processo. Para análise do vínculo entre a atipicidade da prova e a ilicitude ou admissibilidade da prova, mister distinguir entre a atipicidade na produção da prova e a atipicidade na obtenção da prova. No que se refere ao uso de sucedâneos de prova como forma de substituir uma prova típica adequada por outra prova típica indevida, o vício é, em geral, posto pela doutrina como de ordem processual, ou seja, de inadmissibilidade da prova anômala. Também já se tem afirmado que se trataria de uma ilicitude decorrente de vício estrutural: o elemento probatório foi licitamente colhido, mas é ilicitamente transportado para fase na qual não pode ser usado. A relatora colombiana, Dra. Angela Maria Buitrago Ruiz, afirma que há atipicidade probatória no caso de uso de uma prova antecipada. Ressaltaram os relatores brasileiros, Drs. Antonio Magalhães Gomes Filho e Gustavo Henrique Righi Ivahy Badaró, que os elementos da investigação não são provas ilícitas, nem podem ser considerados provas tecnicamente, e eventual uso desses elementos no julgamento representa problema de ilegitimidade. Referiram os relatórios que, em caso de ilicitude, seja por disposições legais (Argentina, Chile, Colômbia, Paraguai), seja em virtude de construções jurisprudenciais (Brasil, Espanha, Uruguai), a prova não deve ser admitida e se admitida não poderá ser levada em conta. A forma de impedir a introdução da prova ilícita na audiência é apresentar questão prévia de ilicitude, exigindo-se o prévio pronunciamento do juiz. Admite-se, ainda, protesto na própria audiência. Se a prova ilícita foi introduzida na audiência e levada em conta no julgamento, será possível recurso. Acentuou a relatora espanhola, Dra. Sara Aragoneses Martinez, que a parte poderá pleitear a declaração de inadmissibilidade da prova como questão prévia ou de prévio pronunciamento, mas, como é difícil saber desde logo se a prova é ilícita, a questão se coloca muitas vezes na sentença; cabe ao juiz explicitar na sentença porque não leva em conta a prova; se a considerar, cabe recurso contra a sentença. Ressaltaram as relatoras portuguesas, 
Conforme Gustavo Badaró e Gomes Filho “devem-se distinguir os meios de provas (ou de obtenção de prova) típicos, para os quais são previstos um procedimento probatório, dos meios de provas (ou de obtenção de prova) atípicos, assim chamados seja porque não previsto pelo legislador ou ainda porque, embora nominados em lei, não há uma previsão legal para o procedimento probatório específico"202 - isto é, não está regulamentado quanto à sua forma de produção.

A obtenção de prova atípica é permitida, em geral, em todos os países, com fundamento na existência de regras que consagram a liberdade probatória ou a não taxatividade dos meios de prova ${ }^{203}$. Significa dizer que a prova, desde que lícita ${ }^{204}$, ou seja, obtida ou produzida com respeito às garantias e liberdades fundamentais, deve ser admitida.

No mesmo sentido perfilia-se a lição de lição de Gustavo Henrique Righi Ivahy Badaró ${ }^{205}$ : "No direito brasileiro, a possibilidade de utilização de um meio de obtenção de prova atípico, não disciplinado em lei, fundamenta-se na liberdade probatória decorrente da regra da não taxatividade dos meios probatórios, na verdade processualmente atingível e em norma processual aplicável aqui por analogia”.

dras. Rosa Maria Rocha e Teresa Alves Martins, que se distingue entre proibições de produção de prova e proibições de valoração de prova. Divide-se a primeira categoria em: proibição de temas de prova; proibição de meios de prova; proibição de métodos ou meios de obtenção de prova. Distingue-se entre as proibições absolutas (tortura, coação ou ofensa à integridade física ou moral) e proibições relativas (intromissão abusiva no domicílio ou na vida privada). Nem sempre a violação de regra de proibição de prova implica proibição de valoração da prova. Foram duas as soluções aventadas nos relatórios para os casos em que a sentença funda-se em prova ilícita: a) anular a sentença e determinar novo julgamento; b) manter ou alterar a sentença, julgando o recurso como se a prova inexistisse (FERNANDES, Antonio Scarance. Prova e Sucedâneos da Prova no Processo Penal (Extraído do Relatório para as XX Jornadas Ibero americanas de Direito Processual Penal em Málaga, Espanha em 2006) publicado na Revista Brasileira de Ciências Criminais. Editora Revista dos Tribunais, $\mathrm{n}^{\mathrm{o}}$ 66, maio/junho de 2007).

${ }^{202}$ BADARÓ, Gustavo Henrique Ivahy e FILHO, Antonio Magalhães Gomes. Prova e Sucedâneos de prova no processo penal brasileiro. Revista Brasileira de Ciências Criminais, número 65, março-abril de 2007, pag175/176.

${ }^{203}$ FERNANDES, Antonio Scarance. Revista Brasileira de Ciências Criminais, no 66, maio-junho de 2007. Editora Revista dos tribunais - IBCCRIM, p. 212.

${ }^{204}$ Carta Magna de 1988, art. 5º, inciso LVI: "são inadmissíveis, no processo, as provas obtidas por meios ilícitos".

${ }^{205}$ Op. Cit. p. 185. 
A base de sustentação da ideia da liberdade probatória ${ }^{206}$ pode ser extraída da regra contida no parágrafo único, do artigo 155, do Código de Processo Penal, que dispõe: "Somente quanto ao estado das pessoas serão observadas as restrições estabelecidas na lei civil". O que significa dizer que no juízo penal, a regra é a de não haver restrições, excetuadas aquelas quanto ao estado das pessoas.

No âmbito processual civil também existe regra traçando a questão da liberdade da prova, inserida no artigo 332 do diploma processual civil ${ }^{207}$ prevendo que: "todos os meios legais, bem como os moralmente legítimos, ainda que não especificados neste Código, são hábeis para provar a verdade dos fatos em que se funda a ação ou a defesa ${ }^{208 "}$. De se frisar, ainda, que ao menos por analogia (art. $3^{\circ}$, do Código de Processo Penal), a regra processual civil pode ser utilizada no campo penal.

A ideia de liberdade da prova, contida nos dispositivos acima referidos, vale tanto para a prova típica (catalogada e regulada em lei) quanto para a prova atípica (aquela apenas nominada, mas sem regulação ou sequer nominada) ${ }^{209}$. O diploma processual

206 Também no Código de Processo Penal Militar, no artigo 295 existe previsão a respeito da liberdade probatória: "Art. 295 - É admissível, nos termos deste Código, qualquer espécie de prova, desde que não atente contra a moral, a saúde ou a segurança individual ou coletiva, ou contra a hierarquia ou a disciplina militares". E o Código de Processo Penal tipo para a Ibero-América prevê, em seu art. 148 a regra da liberdade probatória: “Art. 148. Salvo previsão expressa em contrário da lei, poderão ser provados todos os fatos e circunstâncias de interesse para a correta solução do caso e por qualquer meio de prova permitido. Regerão, em especial, as limitações da lei, relativas ao estado civil das pessoas".

${ }^{207}$ Antonio Magalhães Gomes Filho e Gustavo Henrique Righi Ivahy Badaró comentando o artigo 332 do CPC, afirmam que: "Embora não haja um dispositivo semelhante no Código de Processo Penal, há consenso de que também não vigora no campo penal um sistema rígido de taxatividade dos meios de prova, sendo admitida a produção de provas não disciplinadas em lei, desde que obedecidas determinadas restrições".

${ }^{208}$ Nelson Nery Junior ao comentar o mencionado artigo 332 do Código de Processo Civil assinala que: "meios processuais ou materiais considerados idôneos pelo ordenamento jurídico para demonstrar a verdade, ou não, da existência e verificação de um fato jurídico. É da substância do direito material apontar as hipóteses em que se exige a prova legal - que corresponde à forma do ato jurídico, um dos elementos de sua essência, - bem como a forma como podem ser provados os atos jurídicos que não exigem forma especial. É da substância do direito processual fornecer o rol dos meios de prova admitidos no processo, a discriminação detalhada da forma e do momento de sua produção, bem como a forma e os limites de sua avaliação pelo julgador" (JUNIOR, Nelson Nery e NERY, Rosa Maria de Andrade. Código de Processo Civil Comentado. Ed. R.T., $6^{a}$ ed., 2002, p. 692).

${ }^{209}$ Conforme LARONGA, ainda que não exista uma definição consensual sobre a atipicidade probatória, certo é que esta se contrapõe à prova típica, prevista no ordenamento com seu nomen iuris e seu procedimento próprio regulado. A atípica, em contrapartida, carece de previsão legal, seja quanto à nominação, seja em relação ao seu procedimento (LARONGA, Antonio. Le Prove Atipiche nel Proceso Penal. Editora CEDAM, 2002). 
civil, que se estende analogicamente ao processual penal, não faz distinção entre as provas típicas e atípicas $^{210}$, para fins de sua admissibilidade, assimilando as duas espécies.

Neste diapasão, reitera-se que a entrega vigiada configura nítido meio de obtenção de prova atípico, já que não nominada no ordenamento jurídico interno, ao menos com tal denominação. E, mesmo que se admita sua existência, não foi descrito pelo legislador o procedimento a ser adotado em sua efetiva utilização.

Aliás, essa ausência de detalhamento da metodologia de aplicação não é privilégio apenas da entrega vigiada, mas também da infiltração de agentes ${ }^{211}$ e de outras tantas técnicas de obtenção de provas, representando o principal entrave no emprego de tais institutos. A falta de normatização detalhada passa a ser motivo de crítica principalmente com relação aos abusos que poderão ser cometidos quando de sua utilização, uma vez que não haverá regra delimitadora da atuação para confrontar com o caso concreto.

\subsection{Caráter excepcional da entrega vigiada}

Muito se discute se a entrega vigiada pode ser considerada um meio de investigação excepcional. Para apontar a existência ou não dessa excepcionalidade é preciso esclarecer sob qual ótica se está examinando essa peculiaridade do instituto.

\footnotetext{
${ }^{210}$ Embora haja a admissão das provas atípicas, de se observar, como faz Antonio C. C. Araujo, que não é fácil identificar outros meios, diversos daqueles já referidos pelo legislador, uma vez que as fontes de prova são limitadas, assim como o são as possíveis modalidades da função representativa. Isso vale até mesmo para os meios resultantes do desenvolvimento tecnológico porque se reduzem sempre às noções de documento ou perícia, submetendo-se às regras que disciplinam tais modalidades probatórias (Araújo, Antonio Carlos C.. Comentários ao Código de Processo Civil. Rio de Janeiro, Forense, 2000, v. 4, p. 16-17).

${ }^{211}$ Isaac Sabá Guimarães tratou desta problemática normativa quando dos comentários da figura do agente infiltrado no trecho transcrito: "Não há previsão expressa sobre a conduta a ser seguida pelo agente infiltrado, especificamente sobre atos que eventualmente possam configurar crimes, fato este que inapelavelmente terá de ser tratado pela doutrina e jurisprudência dos tribunais, pois, em inúmeras situações a infiltração levará a alguma conduta criminosa que não poderá ser recusada sob pena de malograr as investigações" (GUIMARÃES, Isaac Sabá. Tóxicos - Comentários, Jurisprudência e Prática, Curitiba: Juruá, 2002, p.207).
} 
Dessa forma, a entrega vigiada pode ser considerada excepcional sob quatro principais prismas: a) utilização apenas para combater crimes graves; b) pela atipicidade desse meio de obtenção de prova; c) por se permitir o cometimento de um delito, quando a regra é contê-lo e; d) por afrontar direito fundamental.

A primeira situação em que se pode considerar que a entrega vigiada possui caráter excepcional diz respeito à aplicabilidade deste meio de investigação. Assim, sustenta-se que a entrega vigiada é uma técnica de investigação excepcional, porque somente deve ser utilizada em casos especiais, de enfrentamento aos crimes graves, notadamente no combate dos delitos praticados pelas organizações criminosas. Portanto, sob este primeiro prisma, a entrega vigiada poderia ser considerada excepcional porque se trata de um meio de investigação que não se emprega na persecução de todo e qualquer crime.

Neste sentido, Luis Fernando Rey Huidobro, no artigo em que trata da entrega vigiada acastelou a excepcionalidade ${ }^{212}$ que a técnica apresenta ao escrever: "De todo modo, parece deduzir-se claramente de uma interpretação teleológica do preceito (não olvidemos que se introduziu na Lei de Enjuiciamiento Criminal espanhola para lutar de um modo efetivo contra a alta criminalidade relacionada com o narcotráfico), que o recurso à

\footnotetext{
${ }^{212}$ Ainda, no mesmo sentido, Guillermo J. Yacobucci dispôs sobre a entrega vigiada como meio extraordinário de investigação para lutar contra crimes de difícil persecução e comprovação: "O surgimento de novas formas criminosas, caracterizadas por suas complexas estruturas de organização e funcionamento, relacionadas geralmente com associações mafiosas, narcotráfico, terrorismo, etc., determinou que os instrumentos investigativos penais, que se mostravam eficazes para fazer frente aos delitos comuns, resultaram desafiados por estes comportamentos ilícitos. E neste contexto, ante o temor de não poder controlar razoavelmente a proliferação dos ataques de ordem social, mercê da limitação instrumental de instituições pensadas para uma sociedade de características distintas, se tornou necessário apelar para uma "legislação de emergência", que introduza novas técnicas excepcionais de investigação para lutar contra este tipo de delinquência, configurada por sua difícil persecução e comprovação". In: (YACOBUCCI, Guillermo J (coord.), El Crimen Organizado, Editorial Ábaco de Rodolfo Depalma, Buenos Aires, pág. 237). No texto foi apresentada tradução livre do seguinte trecho original: "El surgimiento de nuevas formas criminales, caracterizadas por su estructuras complejas de organización o funcionamiento, relacionadas generalmente con asociaciones mafiosas, narcotráfico, terrorismo, etc., determino que los instrumentos investigativos penales, que se mostraban eficaces para hacer frente a los delitos comunes, resultaran desafiados por estos comportamientos ilícitos. En este contexto, ante el temor de no poder controlar razonablemente la proliferación de los ataques al orden social, merced a la limitación instrumental de instituciones pensadas para una sociedad de características distintas, se torno necesario apelar a una "legislación de emergencia", que introdujera nuevas técnicas excepcionales de investigación para luchar contra este tipo de delincuencia, signada por su dificil persecución y comprobación".
} 
entrega vigiada, como medida excepcional que é, deve guardar uma proporcionalidade com a infração penal a qual se dirige a medida ${ }^{213}$.

Por este primeiro aspecto a entrega vigiada deve ser havida por excepcional, na medida em que representa o emprego da técnica somente em casos especiais, levando em consideração a gravidade do delito. A própria ideia da entrega vigiada, consoante visto outrora, nasceu de uma convenção entre Estados intencionada a enfrentar o tráfico ilícito de entorpecentes. Portanto, plenamente justificado que o meio investigativo não seja utilizado para persecução de qualquer tipo de crime, pois é justamente a gravidade do ato ilícito que justifica seja permitida, por certo tempo, a prática delituosa, dada a finalidade do instituto.

Caso contrário, a disseminação da técnica, independentemente do crime a ser perseguido, pode ser capaz de gerar um monitoramento preventivo de toda e qualquer remessa, criando, assim, um verdadeiro Estado disciplinador, de vigilância extremada ${ }^{214}$.

${ }^{213}$ HUIDOBRO, Luis Fernando Rey. La entrega vigilada de drogas: El artículo 263 bis de la Ley de Enjuiciamiento Criminal. Revista Del Ministério Fiscal, Julio-Diciembre 1995, número 2, pág. 201. No texto foi apresentada tradução livre do seguinte trecho original: "De todos modos, parece deducirse claramente de una interpretación teleológica del precepto (no olvidemos que se introduce en la LECRr. para luchar de un modo efectivo contra la alta criminalidad relacionada cone el narcotráfico), que el recurso a la entrega vigilada como medida excepcional que es, debe guardar una proporcionalidad con la infracción penal a la que va dirigida".

${ }^{214}$ Neste aspecto não há como não citar a lição de Luigi Ferrajoli que em sua obra Direito e Razão já apresentava a possibilidade de existência de um Estado disciplinar, cuja característica principal seria a adoção de uma vigilância extremada. Ferrajoli elenca, em alternativa ao direito penal, quatro possíveis sistemas de controle social: a) os sistemas de controle social selvagem (sociedade selvagem); b) os sistemas de controle estatal selvagem (estado selvagem); c) os sistemas de controle social-disciplinar (sociedade disciplinar) e d) os sistemas de controle estatal-disciplinar (Estado disciplinar). Anteviu o autor os problemas das sociedades de controle e vigilância quando descreveu que: "os sistemas de controle estatal-disciplinar são um produto tipicamente moderno e, sobretudo, um perigo futuro, caracterizados pelo desenvolvimento das funções preventivas de segurança pública, mediante técnicas de vigilância total como aquelas consentidas para a espionagem dos cidadãos pelas potentes polícias secretas, bem como dos atuais sistemas informáticos de controle audiovisual e de fichamento generalizado". O último sistema narrado por Ferrajoli (o de controle estatal-disciplinar) é o mais alarmante, em razão da sua capacidade de conviver, ardilosamente, inclusive com as democracias modernas. Nas palavras do autor: "É bem possível eliminar ou reduzir ao máximo os delitos por meio de uma limitação preventiva da liberdade de todos, fazendo uso de carros-tanques nas ruas e com policiais às costas dos cidadãos, mas também - mas modernamente e discretamente -, com o uso de câmeras nos lugares de trabalho e de divertimento, mediante interceptações telefônicas e de todo o aparato de técnicas de informáticas e telemáticas de controle a distância que tornam possível um 'panóptico' social muito mais minucioso e penetrante do que aquele carcerário concebido por Bentham e idôneo não apenas a desenvolver funções de prevenção dos delitos, mas também de governo político da sociedade. Com relação a um sistema assim invasivo, que bem pode combinar-se com medidas de prevenção especial em relação a quem for considerado perigoso, a defesa do direito penal equivale a defesa da liberdade física de transgredir, vez que vetada "deonticamente" e não materialmente impossibilitada. E o direito penal, com aparente paradoxo, configura-se como uma técnica de controle que garante, com a liberdade física de infringir a lei pagando o preço da pena, a liberdade de todos (FERRAJOLI, Luigi. Direito e Razão. São Paulo: Editora Revista dos Tribunais, p. 138). 
Sob um segundo prisma, a entrega vigiada tem sido também considerada excepcional, porquanto se trata de um meio de obtenção de prova atípico, ou seja, sem previsão no ordenamento jurídico ou, ao menos, sem normatização a respeito de um procedimento probatório específico.

Por conta desta situação de inexistência de modelo procedimental a ser seguido na obtenção da prova, a técnica deve ser empregada excepcionalmente, já que sua capacidade de causar desrespeito às garantias do investigado é maior do que nas situações de utilização de provas típicas, devidamente regulamentadas.

Por si só os meios de obtenção de prova - e aqui se insere a entrega vigiada - possuem esse traço de excepcionalidade, uma vez que existindo meios comuns e legalmente previstos de alcançar a prova, torna-se, em regra, despicienda a utilização de meios atípicos.

A entrega vigiada ainda, sob um terceiro prisma pode ser considerada excepcional, pelo fato de se permitir o cometimento de um delito, sem a pronta intromissão estatal.

A entrega vigiada implica em uma demora da intervenção estatal ante o cometimento de um crime, o que significa dizer que a entrega vigiada se verifica em face de um delito conhecido, mas não imediatamente impedido, porque mantido sob vigilância das autoridades. Dessa maneira, a técnica de investigação representa uma exceção específica do dever que incumbe às autoridades de impedir os delitos, interrompendo a situação de flagrância $^{215}$. A excepcionalidade da medida é permitida justamente para fazer frente ao crime organizado, que inegavelmente autoriza a circulação de remessas ilícitas, no intuito de alcançar os verdadeiros líderes da organização.

\footnotetext{
${ }^{215}$ Neste aspecto a entrega vigiada diverge do flagrante esperado, em que a polícia, na maioria das vezes através de informação anônima, toma conhecimento de que um ilícito será praticado em determinado local e fica à espreita aguardando o momento da execução para efetivar a prisão em flagrante. Desta forma, a autoridade aguarda o momento em que o crime será cometido e, em acontecendo, intervém. Já na entrega vigiada a autoridade tem conhecimento prévio do crime e permite sua continuidade sob monitoramento.
} 
O marco da entrega vigiada ocorre na medida em que as autoridades públicas passam a tolerar a circulação de gêneros proibidos, comportamento que se afasta da repressão de um delito conhecido. Tais operações desvirtuam das regras do Estado de Direito, por isso, o caráter excepcional do meio de investigação.

\section{Para Marta Gómez de Liaño Fonseca-Herrero"216 “a entrega vigiada} compartilha com o agente infiltrado a nota do consentimento estatal de permissão de acompanhamento de uma atuação delitiva plenamente conhecida. Precisamente, por este motivo, ambos os instrumentos processuais são qualificados como meios extraordinários de investigação. Para referida autora a mais importante peculiaridade, tanto do agente infiltrado, quanto da entrega vigiada, não reside na afronta de direitos fundamentais das pessoas submetidas à investigação (embora esta ocorra, igualmente como também ocorre nas diligências de intervenção telefônica), senão na permissão e tolerância por parte do Estado na continuidade de um fato sabidamente punível, durante certo período de tempo, no intuito de enfrentar o fenômeno do crime organizado".

O último aspecto sob o qual se examina a questão da excepcionalidade da entrega vigiada diz respeito à possibilidade de afronta a direito fundamental. Neste prisma, a questão é mais delicada e surgem fervorosas discussões ${ }^{217}$.

Existe corrente doutrinária ${ }^{218}$ sustentando que a entrega vigiada, por ser um meio de investigação baseado no monitoramento, de per si, pode afrontar direitos fundamentais - no mínimo o direito à intimidade - devendo, portanto, ser considerada uma técnica excepcional.

\footnotetext{
${ }^{216}$ FONSECA-HERRERO, Marta Gómez de Liaño. Criminalidad Organizada y medios extraordinarios de investigación. Editorial Colex, Madrid: 2004, p. 287.

${ }^{217}$ A questão central que se põe consiste na verificação se a entrega vigiada é capaz de afrontar direito fundamental. E se tal meio de investigação sempre afronta direito fundamental ou apenas em algumas hipóteses haverá essa violação. Em capítulo próprio esse tema será analisado.

${ }^{218}$ Nessa corrente possível citar Marta Gómez de Liaño Fonseca Herrero, para quem: "la circulación y entrega vigilada de elementos ilícitos constituye un instrumento para investigación penal de la criminalidad organizada limitativo, en función de la natureza del proceso comunicativo del derecho fundamental al secreto de las comunicaciones, y del derecho a la intimidad", In:Criminalidad Organizada y medios extraordinarios de investigación. Editorial Colex, Madrid: 2004, p. 297.
} 
No entanto, ainda que se admita posição diversa, sustentando que a entrega vigiada não entra na esfera de desrespeito dos direitos fundamentais, quando somente monitora o trânsito de remessas ilícitas, não atingindo garantias do investigado, certo é que ao menos na modalidade de entrega vigiada tida como substituição, em que o conteúdo da remessa é violado e substituído por outro material, ocorre afronta ao sigilo das comunicações.

De forma que, por este último aspecto, dependendo da forma como ocorrerá a entrega vigiada, haverá afronta a direitos fundamentais, notadamente ao sigilo das comunicações e, por consequência ao direito à intimidade, o que reforça o caráter excepcional da medida.

\subsection{Formas de entrega vigiada}

Da previsão contida na Convenção de Viena de 1988, o primeiro tratado internacional a contemplar a entrega vigiada (excetuado o Convênio de Schengen), diversos doutrinadores e algumas legislações vêm classificando e diferenciando algumas formas possíveis de utilização da entrega vigiada.

Tal possibilidade pode ser extraída da previsão contida no artigo 11, item 3, da supracitada Convenção, que dispõe:

“3. As remessas ilícitas, cuja entrega vigiada tenha sido negociada poderão, com o consentimento das Partes interessadas, ser interceptadas e autorizadas a prosseguir intactas ou tendo sido retirado ou subtraído, total ou parcialmente, os entorpecentes ou substâncias psicotrópicas que continham”.

Portanto, partindo deste dispositivo a doutrina vislumbra três formas principais na utilização da entrega vigiada, classificando-as em: interdição, substituição ou acompanhamento. 


\subsubsection{Interdição}

$\mathrm{Na}$ interdição o instituto da entrega vigiada, de certa maneira, é um pouco desvirtuado, vez que a entrega da remessa ilícita ao seu destino é interrompida com a apreensão desta, porém, desde que atingidos seus objetivos de desmantelamento da quadrilha e identificação dos envolvidos.

Dessa forma, nesta modalidade de entrega vigiada ocorre, conforme sua própria denominação, uma interdição, interrompendo a ação para realizar uma apreensão antecipada relativamente ao momento inicialmente previsto, uma vez que se atingiu o objetivo para qual o instituto existe.

Esta modalidade pode ser constatada no seguinte trecho do texto da Convenção de Viena: "As remessas ilícitas, cuja entrega vigiada tenha sido negociada poderão, com o consentimento das Partes interessadas, ser interceptadas” (...).

Contudo, se entrega vigiada tem por definição a permissão para que remessas ilícitas ou suspeitas de entorpecentes ou outras substâncias proibidas circulem pelo território nacional, bem como dele saiam ou nele ingressem, sem interferência impeditiva da autoridade ou seus agentes, mas sob sua vigilância, com o fim de descobrir ou identificar as pessoas envolvidas no cometimento de algum delito de elevada gravidade, bem como prestar auxílio a autoridades estrangeiras nesses mesmos fins, haverá, pelo menos à primeira vista, distorção entre a essência do instituto e a presente modalidade: por isso, pode ser considerada uma forma anômala do instituto.

Essa modalidade de interdição se torna mais compreensível quando se interpreta que a interdição não representa abrupta interrupção do procedimento da entrega vigiada, mas tão somente seu encerramento precoce, isto é, sua finalização em momento anterior e distinto do planejado inicialmente em razão da conclusão de seus objetivos. O 
procedimento, na verdade, encerra-se com uma ação que ocorre durante a tramitação das mercadorias ilícitas, interrompendo-a.

A modalidade em exame poderá ser empregada quando as autoridades já houverem colhido provas suficientes para o desbaratamento de toda a organização. Dessa forma, poderá interditar, preventivamente, para que a remessa ilícita não alcance seu destino, evitando o risco de extravio, já que a missão de investigação já atingiu seu objetivo.

\subsubsection{Substituição}

$\mathrm{Na}$ modalidade substituição as remessas ilícitas (carga, mercadoria ou droga ilegal) são trocadas antes de serem entregues ao destinatário final por um outro produto qualquer, um simulacro, afastando-se o risco de perda ou extravio ${ }^{219}$, o que se convencionou chamar de "entrega limpa"220, uma vez que o objeto que alcança o destino, após sua substituição por outro inócuo, deixou de ser ilícito.

\section{Victor Roberto Prado Saldarriaga ${ }^{221}$ conceituou a modalidade por} substituição como "aquela onde as espécies ou bens ilícitos originais que devem circular são substituídos total ou parcialmente por objetos ou substâncias similares, porém inócuos e lícitos".

${ }^{219}$ Joaquín Delgado Martin, escritor de diversas obras e artigos sobre a criminalidade organizada, vem tratando de forma reiterada o instituto da entrega vigiada e levanta esta questão, expondo in litteris: "Sem embargo, a organização criminosa tem à sua disposição abundantes meios materiais e humanos, muitas vezes superiores a dos agentes das forças e corpos de segurança, que podem abortar a operação e desviar a droga conseguindo fazêla chegar ao mercado, mesmo diante do controle policial. De outro lado, concorre com o risco de extravio da substância, que aumenta naquelas operações em que a polícia pode apreender o quanto antes a droga, evitando assim que chegue aos consumidores" (MARTIN, Joaquín Delgado. La Criminalidad Organizada, J.M. Bosch editora Barcelona, 2001. No texto foi apresentada tradução livre do seguinte trecho original: "Sin embargo, la organización criminal tiene a su disposición abundantes medios materiales y humanos, muchas veces superiores a los de los agentes de las fuerzas y cuerpos de seguridad, que pueden abortar la operación y distraer la droga consiguiendo hacerla llegar al mercado lejos del control policial. Por otra parte, concurre el riesgo de extravió de la substancia, que aumenta en aquellas operaciones en las que la policía no pone aprehender cuanto antes la droga, evitando así que llegue a sus consumidores).

${ }^{220}$ Francisco Almazán Sepúlveda utilize a denominação entrega limpa para denominar a entrega vigiada na modalidade de substituição. Op. cit. 22.

${ }^{221}$ SALDARRIAGA, Victor Roberto Prado. Artigo: La entrega Vigilada: Orígenes Y desarrollos. Cit. p. 166. 
Entende-se que a Convenção de Viena autorizou a possibilidade de substituir as remessas ilícitas quando utilizou a expressão: “(...) tendo sido retirado ou subtraído, total ou parcialmente, os entorpecentes ou substâncias psicotrópicas que continham".

Nesta modalidade não ocorre, na verdade, a interceptação da remessa sob acompanhamento das autoridades competentes. Todavia, há a substituição do objeto ilícito vigiado por outro, não ilícito ou de menor valor, para atenuar o risco de perda ou extravio da remessa.

Caso recorrente de utilização da entrega vigiada na modalidade de substituição acontece com a troca de substâncias tóxicas, como a cocaína, por substâncias de aparência similar, como o talco ou farinha.

Desta maneira, ainda que porventura ocorra uma falha na operação de monitoramento o objeto estará a salvo, apreendido pelas autoridades, diminuindo sobremaneira o risco da operação.

Kristian Holgeasesor ${ }^{222}$, no VIII Simpósio Internacional de Criminalística comentou sobre a possibilidade de utilização da entrega vigiada sob a modalidade de substituição, mencionando que: "a entrega vigiada por substituição tem lugar quando as drogas contrabandeadas são removidas dos recipientes e substituídas por material de imitação, por exemplo, farinha, que não representa contrabando. A substituição pode ser parcial ou total, segundo os requisitos legais e os procedimentos locais. O recipiente, com conteúdo substituído é entregue normalmente ao destinatário e se seguem, em consequência, os procedimentos legais".

${ }^{222}$ HOLGEASESOR, Kristian. La Fiscalización Internacional de drogas y la técnica de entrega vigilada. VIII Simpósio internacional de Criminalística. No texto foi apresentada tradução livre do seguinte trecho original: "la entrega vigilada por substitución tiene lugar cuando las drogas de contrabando se sacan de los contenedores y se sustituyen por material de imitación, por ejemplo, harina, que nos es de contrabando. La substitución puede ser parcial o total, según los requisitos legales y los procedimientos locales. El contenedor, con contenido de substitución, se entrega al destinatario normalmente y se siguen em consecuencia los procedimientos legales". 
O Código de Processo Penal da Espanha (Lei de Enjuiciamiento Criminal) contemplou expressamente, no artigo 263 bis, a possibilidade de que a operação se realize com a substituição da substância ou elemento ilícito por outra inócua.

Entretanto, ao comentar a legislação espanhola, recorda Jaime Vegas Torres $^{223}$ que "a substituição não é um elemento essencial da entrega vigiada, senão uma mera possibilidade que poderá ser utilizada ponderando os riscos de perda da droga se a operação vier a fracassar".

Questão relevante e bastante discutida envolve esta forma de entrega vigiada por substituição: trata-se da verificação da existência ou não de afronta a direitos fundamentais.

Isto porque, em qualquer caso que se optar pela substituição do objeto vigiado, inevitavelmente resultará necessária a abertura do pacote que contenha a substância ilícita, como meio para se proceder à aludida troca. E dessa forma, principalmente nos casos de rompimento de correspondências (quando a remessa se der por meio de cartas ou pacotes postais) surge a questão da preservação dos direitos fundamentais.

Neste caso, especificamente da abertura de pacote, culminará afetado direito fundamental do sigilo das comunicações, deve se exigir que a operação de substituição conte com a obrigatória intervenção judicial, para que o procedimento não se torne viciado.

\subsubsection{Acompanhamento}

${ }^{223}$ TORRES, Jaime Vegas. Detención y apertura de paquetes postales: especial consideración de la apertura de
paquetes en el marco de las entregas vigiladas. Tribunales de justicia: Revista española de derecho procesal,
1997, p. 862 . 
A modalidade acompanhamento caracteriza a entrega vigiada em sua essência, pela qual a remessa ilícita transita livremente sob monitoramento, chegando ao seu destino sem interrupção ou substituição do conteúdo.

A operação ilícita é acompanhada o tempo todo, sob vigilância, com a identificação do maior número possível de integrantes da organização criminosa, do modus operandi e de uma quantidade maior de mercadorias ilícitas ${ }^{224}$.

Trata-se, na verdade, da entrega vigiada em sua forma clássica, cuja característica básica é o acompanhamento, o monitoramento, a vigilância da remessa ilícita com o conhecimento e sob a supervisão de suas autoridades competentes, com o fim de identificar as pessoas envolvidas, seu modus operandi e desbaratamento da organização criminosa.

Esta espécie caracteriza-se como a modalidade padrão da entrega vigiada e, por tal motivo, consta de sua própria e clássica definição.

\subsubsection{Outras modalidades}

Além das três formas explicitadas: interdição, substituição e monitoramento existem, ainda, outras modalidades previstas na doutrina.

Joaquín Delgado Martín ${ }^{225}$, por exemplo, classifica as formas de entrega vigiada em: a) 'entrega vigilada positiva ou ativa'; b) 'com substitución’ e c) 'entrega vigilada internacional'.

${ }^{224}$ GOMES, Rodrigo Carneiro e SANTOS, Getúlio Bezerra. Artigo: Ação controlada é eficaz contra o crime organizado.

${ }^{225}$ MARTÍN, Joaquín Delgado. La Criminalid Organizada. J.M. Bosch Editor - Barcelona, 2001. p.142. 
Nessa classificação o autor prevê a modalidade utilizada com a substituição da remessa ilícita, modalidade esta que se inclui na classificação tradicional já delineada no item 3.4.2. Inova apenas nas duas outras formas: a positiva ou ativa (letra a) e a internacional (letra c).

A modalidade denominada como positiva ou ativa, de fato, não se encontra naquela classificação tripartite, porque não é admitida em lei. Consiste apenas numa hipótese ventilada pela doutrina, mas que não deve ser adotada, porquanto representa verdadeira atuação ilícita e não simples monitoramento.

Por esta modalidade ativa a substância ou o elemento ilícito é posto em circulação pelo próprio Estado, através dos agentes de polícia. Desta maneira, há uma ação inicial por parte das autoridades, que explica a denominação de positiva ou ativa.

Ainda que seja uma técnica capaz de produzir resultados eficientes na investigação dos delitos cometidos por uma organização criminosa, a verdade é que tal modalidade não se enquadra na acepção da entrega vigiada, pois nesta as práticas ilícitas de remessa são realizadas pelos integrantes da própria organização e dirigidas a outras pessoas, todas alheias à estrutura estatal.

Os agentes executores da vigilância, autorizados pelas autoridades competentes, limitam-se a permitir a circulação e a respectiva entrega da remessa ilícita, vigiando essa movimentação para obtenção de meios de provas. Não há qualquer tipo de permissão prevista para que haja atuação comissiva ilícita, mas somente omissão autorizada ("não-atuação" policial - é a letra da lei).

A única ação excepcionalmente permitida em algumas legislações e na Convenção de Viena é a substituição dos elementos ilícitos, mas que está bem distante da inserção desses elementos em circulação, pois esta significaria nítida atuação do Estado no cometimento de delito. 
A vedação desta forma positiva ou ativa é facilmente perceptível quando se analisa os verbos contidos no dispositivo da entrega vigiada, quais sejam: "permitir (...) sob vigilância e sem interferência”. É típica atuação omissiva autorizada.

Já com relação à classificação do autor Joaquim Delgado, no tocante à entrega vigiada internacional, dá-se a mesma quando na operação vêm implicados os poderes punitivos de vários Estados, que está cada vez mais frequente por conta do fenômeno da transnacionalização do crime organizado, favorecido pelo processo de liberação do comércio em nível mundial.

Victor Roberto Prado Saldarriaga ${ }^{226}$, por sua vez, em distinta classificação das apresentadas anteriormente, elenca três classes de entrega vigiada: a) entrega vigiada com substituição ou entrega limpa; b) entrega vigiada interna ou de destino; e c) entrega vigiada externa ou de origem e trânsito.

Consoante demonstrado, nas classificações anteriores a forma de entrega vigiada por substituição vem comumente apontada dentre as modalidades possíveis de utilização desta técnica de investigação (objeto de análise anterior).

Com relação à entrega vigiada interna ou de destino esta tem lugar quando a informação sobre a remessa de espécies ilícitas é obtida pelas autoridades do Estado de destino da mesma. Nessa situação o requerimento para acionar ou iniciar o procedimento da entrega vigiada seria de responsabilidade do Estado de origem ou os de trânsito da remessa.

Na entrega vigiada externa ou de origem e trânsito ocorre nos casos em que a informação sobre a remessa e circulação das espécies ilícitas são recepcionadas ou produzidas pelas autoridades do Estado onde se origina o envio ou pelas autoridades de qualquer outro Estado por onde a remessa ilegal deva transitar até seu lugar de destino.

226 SALDARRIAGA, Victor Roberto Prado. La Entrega Vigilada: orígenes y desarrollos, in <http://www.unifr.ch/derechopenal/articulos/pdf/02septiembre06/entregavigilada_prado.pdf>. 
Corresponderá a tal Estado de origem ou trânsito a decisão e coordenação da operação de entrega vigiada em consonância com os demais Estados que estejam envolvidos com a circulação e destino das espécies controladas, fazendo-se necessário chegar a um acordo entre os países participantes.

Por fim, o autor Mario Daniel Montoya ${ }^{227}$ utilizou critério diverso para estabelecer sua classificação quanto às formas de entrega vigiada, ou classes, como preferiu denominá-las.

Para Montoya distinguem-se dois tipos de entregas: a direta e a de trânsito. A direta é aquela que envolve apenas dois Estados na operação de transferência da substância ilícita, o do lugar de partida e outro do ponto de destino final da remessa.

Já a entrega de trânsito caracteriza-se pela intervenção de ao menos três Estados, sendo que um deles participará apenas autorizando o trânsito dos elementos ilícitos sobre seu próprio território, ou seja, é mero Estado de passagem, que se encontra no meio da rota de origem e destino. Embora tenha o dever de continuar o monitoramento da remessa no âmbito interno de seu país.

Há, ainda, na doutrina a referência a outras formas menos expressivas de entrega vigiada, de denominações distintas das previstas, mas que se subsumem, de uma forma ou de outra, nas modalidades acima explicitadas.

\subsection{Requisitos da entrega vigiada}

A lei exige uma série de requisitos ${ }^{228-229}$ a serem preenchidos para averiguação da correta utilização de um instituto.

\footnotetext{
${ }^{227}$ MONTOYA, Mario Daniel. Informantes y Técnicas de Investigación Encubiertas. Análisis Constitucional y Procesal Penal, $2^{\mathrm{a}}$ edição, Editora Ad Hoc, Buenos Aires, p. 333.
} 
No caso do procedimento investigatório da entrega vigiada, tomando por base as regras contidas em âmbito internacional ${ }^{230}$, nos tratados ratificados pelo Brasil, especificamente pela Convenção de Viena de 1988, pode-se apontar como requisitos ${ }^{231}$ caracterizadores da entrega vigiada:

1) Autoridade competente para a concessão da autorização;

${ }^{228}$ Carlos Enrique Edwards explica que "o fundamento para tais requisitos formais advém da própria natureza da entrega vigiada, de exceção consistente na obrigação de que todo funcionário público que tiver conhecimento de um delito em ocorrência do dever de denunciá-lo e quando for sua competência, persegui-lo" (El arrepentido, El agente Encubierto y la entrega Vigilada. Ad Hoc, Buenos Aires).

${ }^{229}$ Segundo Rodrigo Carneiro Gomes "são requisitos da entrega vigiada: imprescinde de autorização judicial, depende de prévia oitiva do representante do Ministério Público; repressão de crime de tráfico de drogas e outros reprimidos pela Lei 11.343/2006; não-atuação policial permitida em lei; aplicação na repressão contra portadores de drogas, seus precursores químicos ou outros produtos utilizados em sua produção; exige que o objeto do delito e autores se encontrem no território brasileiro (não necessariamente todos os integrantes do grupo de traficantes ou da organização criminosa); finalidade de identificar e responsabilizar maior número de integrantes de operações de tráfico e distribuição, sem prejuízo da ação penal cabível; autorização mediante conhecimento do itinerário provável e a identificação dos agentes do delito ou de colaboradores" Op. cit. p. 123.

${ }^{230}$ A entrega vigiada na Espanha possui os seguintes requisitos apontados por Luis Fernando Rey Huidobro (op. cit. p.158): a) La circulación o entrega vigilada deberá estar autorizada indistintamente por: El juez de Instrucción competente, el ministerio Fiscal, los jefes de las Unidades Orgánicas centrales de la Polícia judicial o de ámbito provincial o sus Mandos superiores; b) La medida será acordada por resolución fundada, en la que se determine explícitamente, en cuanto sea posible, el objeto de la autorización o entrega vigilada, así como el tipo y cantidad de la sustancia de que se trate; c) Se tendrá en cuenta la necesidad de la medida, a los fines de la investigación, en relación con la importancia del delito y con las posibilidades de vigilancia; d) Se deberá realizar caso por caso y, en el plano internacional, se adecuará a lo dispuesto en los tratados internacionales, utilizando los canales de la Oficina Central Nacional de estupefacientes (OCNE) y, en sus respectivos ámbitos, las oficinas de INTERPOL, EUROPOL y SIRENE; e) Los jefes de las Unidades Orgánicas centrales de la Policía Judicial o de ámbito provincial o sus Mandos superiores darán cuenta inmediata al Ministerio Fiscal, sobre las autorizaciones que hubiesen otorgado y, si existiese procedimiento abierto, al juez de Instrucción competente.

${ }^{231}$ No presente trabalho sustentamos a ausência de previsão legal na legislação ordinária brasileira do instituto da entrega vigiada. Isto porque, apontamos que a regra contida na Lei de drogas, inciso II, do artigo 53, refere-se à ação controlada. Todavia, para a corrente que sustenta que referida previsão (art.53, inc. II, da lei de drogas) diz respeito à técnica da entrega vigiada, tal corrente passa a apontar os seguintes requisitos para o emprego do instituto: 1) permissão para utilização em qualquer fase da persecução criminal referente a um dos crimes previstos na Lei de Tóxicos; 2) autorização de um Juiz de Direito, após oitiva do Ministério Público; 3 ) não atuação policial sobre os portadores de drogas ou outras substâncias a elas relacionadas, que se encontrarem no território brasileiro; 4) finalidade de descobrir pessoas e provas envolvidas na prática do delito de tráfico de entorpecentes e coletar provas 5) conhecimento do itinerário provável e a identificação dos agentes ou seus colaboradores. Referidos requisitos, para a corrente que defende a previsão interna da entrega vigiada, são extraídos da própria previsão normativa constante do artigo 53, inciso II e parágrafo único, da Lei de drogas, as verificar: Artigo 53 - Em qualquer fase da persecução criminal relativa aos crimes previstos nesta Lei (requisito 1), são permitidos, além dos previstos em lei, mediante autorização judicial e ouvido o Ministério Público (requisito 2), os seguintes procedimentos investigatórios:(...) A não-atuação policial sobre os portadores de drogas, seus precursores químicos ou outros produtos utilizados em sua produção, que se encontrem no território brasileiro (requisito 3), com a finalidade de identificar e responsabilizar maior número de integrantes de operações de tráfico e distribuição (requisito 4), sem prejuízo da ação penal cabível. Parágrafo Único - Na hipótese do inciso II deste artigo, a autorização será concedida desde que sejam conhecidos o itinerário provável e a identificação dos agentes do delito ou de colaboradores (requisito 5). 
2) Finalidade de descobrir pessoas e provas envolvidas na prática do delito de tráfico internacional de entorpecentes e coletar provas;

3) Existência de acordos internacionais que permitam a vigilância entre diversos países (respeitados os princípios fundamentais dos respectivos ordenamentos jurídicos internos);

4) As decisões que autorizarem a entrega vigiada devem ser analisadas de acordo com cada caso em concreto.

Os requisitos aqui apontados são aqueles atualmente exigíveis para o emprego da entrega vigiada, de acordo com a convenção internacional de Viena ${ }^{232}$.

De toda sorte, será apresentado e examinado de forma pormenorizada, em capítulo futuro, todos os requisitos ponderados como imprescindíveis para a correta utilização da entrega vigiada, respeitadas as garantias individuais do investigado, que deveriam estar previstos na legislação interna sobre o tema.

\subsection{Interdependência da entrega vigiada com o agente infiltrado ou com outros meios de obtenção de prova para a efetiva consecução dos objetivos da entrega vigiada}

\footnotetext{
${ }^{232}$ Tais requisitos extraem-se da própria previsão normativa constante do artigo $1^{\circ}$, inciso $1 \mathrm{e}$ do artigo 11 do aludido acordo internacional, conforme grifos nossos, abaixo transcritos:

Artigo $1^{\circ}$, inciso 1- Convenção de Viena: Por entrega vigiada se entende a técnica de deixar que remessas ilícitas ou suspeitas de entorpecentes, substâncias psicotrópicas, substâncias que figuram no Quadro I e no Quadro II anexos nesta Convenção, ou substâncias que tenham substituído as anteriormente mencionadas, saiam do território de um ou mais países, que o atravessem ou que nele ingressem, com o conhecimento e sob a supervisão de suas autoridades competentes (requisito 1), com o fim de identificar pessoas envolvidas em praticar delitos especificados no parágrafo 1 do Artigo 2 desta Convenção (requisito 2).

Artigo 11: 1) Se os princípios fundamentais dos respectivos ordenamentos jurídicos internos o permitirem, as Partes adotarão medidas necessárias, dentro de suas possibilidades, para que se possa recorrer, de forma adequada, no plano internacional, à entrega vigiada, com base nos acordos e ajustes mutuamente negociados (requisito 3), com a finalidade de descobrir as pessoas implicadas em delitos estabelecidos de acordo com o parágrafo 1 do Artigo 3 e de encetar ações legais contra estes (requisito 2). 2) As decisões de recorrer à entrega vigiada serão adotadas, caso a caso (requisito 4), e poderão, quando necessário, levar em conta ajustes financeiros e entendimentos relativos ao exercício de sua competência pelas Partes interessadas. 3) As remessas ilícitas, cuja entrega vigiada tenha sido negociada poderão, com o consentimento das Partes interessadas, ser interceptadas e autorizadas a prosseguir intactas ou tendo sido retirado ou subtraído, total ou parcialmente, os entorpecentes ou substâncias psicotrópicas que continham".
} 
A entrega vigiada requer, na maioria das vezes, o emprego de outros métodos de investigação concomitantes ou utilizados sucessivamente com a entrega vigiada, para que venha surtir os efeitos almejados. Por exemplo: a necessidade de agentes infiltrados ${ }^{233}$ para se determinar qual será a o provável itinerário ${ }^{234}$ da remessas ilícitas a serem vigiadas.

Tal fato ocorre porque para a eficiente aplicação da entrega vigiada é preciso conhecer previamente algumas informações, como o caminho a ser percorrido pelo portador do produto (itinerário provável), substância ou droga ilícita, com elevada probabilidade de acerto. Do contrário, autorizar o trânsito de pessoas carregando objetos

\footnotetext{
${ }^{233}$ Surgiu a figura do agente infiltrado dentro de uma crescente exigência social e de uma resposta clara tanto do Direito Penal como do Direito Processual Penal em relação a um tipo de criminalidade diferente da comum, chamada criminalidade organizada, também chamada de narcocriminalidade e os delitos dele derivados, assim como os conexos. A figura já existia na Dinamarca desde 1986 nos parágrafos 754a a 754e do Retsplejelov (Lei processual dinamarquesa) (INCHAUSTI, Fernando Gascón. Infiltración Policial y "agente encubierto", p. 45). Na Itália, a previsão existe desde 1990, na lei de entorpecentes, no art. 97 do Decreto do Presidente da República $\mathrm{n}^{\mathrm{o}} 39$ e depois foi também incluído da lei especial normativa de luta contra a criminalidade mafiosa, no art. 12quarter do Decreto-Lei de 08 de junho de 1992, nº 306 (INCHAUSTI, Fernando Gascón. Infiltración Policial y "agente encubierto", p. 50). A legislação francesa que permite a infiltração é datada de 1991, com a entrada em vigor da lei especial em matéria de luta contra o tráfico de entorpecentes. Na Alemanha, existe a figura desde 1992 (Gesetz zur Bekämpfung des illegalen Rauschgifthandels und anderer Erscheinungsformen der Orfanisierten Kriminalität - abreviadamente, OrgKG), que introduziu na StPO os parágrafos 110a a 110e, que permitem a utilização do verdeckter Ërmittler . Em Portugal, a figura surgiu em 1993, com a lei do tráfico ilícito de entorpecentes (art. 59, Decreto-Lei 15/93, de 22 de janeiro) e logo depois em 1994 a possibilidade de utilização do agente infiltrado foi inserida na lei contra a corrupção e a criminalidade econômica e financeira, através da lei número 36/94, de 29 de setembro. Hoje, em Portugal, conforme será exposto em capítulo posterior, existe uma lei única que trata exclusivamente do agente encoberto (Lei 101/2002, de 25 de agosto). A Lei espanhola surgiu também como a brasileira: LO 5/99, de 13 de enero, de modificação da Ley de Enjuiciamiento Criminal (282-bis) na parte que trata do aperfeiçoamento da ação investigadora relacionada com o tráfico ilegal de drogas e outras atividades ilícitas graves. Esta lei incluiu três novos instrumentos que têm por finalidade auxiliar o combate à criminalidade organizada: a entrega vigiada, a supressão da presença do interessado na abertura de correspondência e, por último, o agente encoberto MARTIN, Joaquín Delgado, Problemas Actuales de la Justicia Penal, coordenação de Joan Pico i Junoy, $1^{\text {a }}$ edição, Jose Maria Bosch Editor, Barcelona, 2001, p. 92. Assim surgiu a figura do agente encubierto na Espanha. Tornou-se necessária a regularização deste meio de investigação porque, na verdade, este já vinha sendo utilizado, no entanto, sem qualquer regulamentação, o que dava causa a nulidades pela má aplicação da técnica. As leis brasileiras, no que se refere à infiltração de agentes, também surgiram com a finalidade de combater essa criminalidade moderna. Houve necessidade de criação de outros meios investigatórios e, assim, foram inseridas nas leis do crime organizado, em 2001 (a lei 10217/01 alterou parte da lei 2034/95, que dispõe sobre a utilização de meios operacionais para a prevenção e repressão de ações praticadas por organizações criminosas) e na lei de entorpecentes, em 2002, a possibilidade de infiltração (a lei 10409/02 alterou aspectos da lei 6368/76 que trata dos meios de prevenção e repressão ao tráfico ilícito de entorpecentes).

${ }^{234}$ Exigência prevista no parágrafo único do artigo 53 da lei de drogas ( $\left.n^{\circ} 11.343 / 06\right)$ : Na hipótese do inciso II deste artigo, a autorização será concedida desde que sejam conhecidos o itinerário provável e a identificação dos agentes do delito ou de colaboradores.
} 
ilícitos sem se ter noção de onde veio e para onde vai é altamente arriscado, fator que pode gerar indevida impunidade. ${ }^{235}$

Outras vezes a identificação prévia dos agentes do delito ou colaboradores é de crucial importância para se desvendar dia, hora e local por onde as remessas ilícitas deverão transitar. Não se vislumbra outra possibilidade de descoberta destas informações, para que se possa autorizar a entrega vigiada, senão por meio da prévia utilização de outros meios de investigação, como, no exemplo dado, o emprego do agente infiltrado ou, ainda, a utilização da quebra de sigilo telefônico.

Subsequentemente, de posse de tais informações, a autoridade competente, legitimamente autorizada por lei, terá subsídios suficientes para fundamentar o emprego da técnica investigativa no caso concreto, podendo apontar o itinerário provável da remessa ilícita e a identificação dos agentes envolvidos, pelo menos aqueles já desvendados neste período da investigação.

Neste sentido, Carlos Enrique Edwards preleciona: "Ademais, a entrega vigiada se complementa com outra técnica de investigação, como a atuação do agente encoberto, já que este ao se infiltrar na organização criminosa dedicada ao tráfico ilícito de entorpecentes, pode desvendar a informação necessária sobre o envio de um carregamento, lugar por onde circulará, meio de transporte utilizado e lugar de destino. Por isso, para garantir o êxito da investigação, resultará conveniente a combinação da atuação do agente encoberto com a entrega vigiada ${ }^{236,}$.

Dessa forma, para se utilizar a entrega vigiada, regra geral, será necessária a utilização de outros meios excepcionais de investigação, como a interceptação

${ }^{235}$ NUCCI, Guilherme de Souza. Leis Penais e processuais penais comentadas, Ed. RT, 2007, p. 812.

${ }^{236}$ EDWARDS, Carlos Enrique. El arrepentido, El agente Encubierto y la entrega Vigilada. Ad Hoc, Buenos Aires. Tradução livre do trecho original: "Además, la entrega vigilada se complementa con otra técnica de investigación, como es la actuación del agente encubierto, ya que este al infiltrarse en la organización dedicada al tráfico ilícito de estupefacientes, puede suministrar la información necesaria sobre el envio de un cargamento, lugar por el cual circulará, medio de transporte utilizado, y lugar de destino. Por ello, para garantizar el éxito de la investigación, resultará conveniente la combinación de la actuación del agente encubierto y la entrega vigilada." 
telefônica ou a infiltração de agentes. De outro modo dificilmente obter-se-ão eventuais informações do itinerário provável da droga, das características da remessa ilícita e a identificação dos supostos agentes e colaboradores, além de outras informações relevantes que servirão de subsídios para o emprego da entrega vigiada, até mesmo para que haja elementos mínimos autorizadores da concessão da medida pela autoridade competente. 


\section{CAPÍTULO IV \\ ENTREGA VIGIADA NA LEGISLAÇÃO ESTRANGEIRA}

\subsection{Análise do instituto no sistema legal estrangeiro}

O estudo de todo e qualquer instituto legal, principalmente quando se trata de algo novo, como é o caso da entrega vigiada, deve ser feito traçando um paralelo com o quanto disposto no direito alienígena vigente.

Isto porque a verificação das regras e dispositivos normativos nos demais países sobre o instituto em exame permite a visão global do tema analisado, facilitando o entendimento de sua finalidade, modo de aplicação, sucesso de utilização em cada país, além dos erros - a serem descartados -, e acertos - a serem adotados - pelo Estado que porventura vier a adotar o instituto em sua legislação interna.

Ademais, é fundamental o exame do direito estrangeiro neste tema, uma vez que esta técnica de investigação se fundamenta, basicamente, na cooperação internacional, em face do quanto disposto nos diversos acordos internacionais que tratam do assunto.

De fato, a utilização da técnica da entrega de remessas ilícitas monitoradas no âmbito internacional pressupõe o comum acordo entre os países que efetuarão a vigilância no caso concreto. O que expressa a necessidade de observância das normas legislativas dos países envolvidos e ainda das convenções por eles ratificadas, para que não haja óbices jurídicos, nem afronta aos direitos fundamentais de cada Estado participante do monitoramento. Consequentemente, o conhecimento dos demais ordenamentos jurídicos sobre o assunto se revela de extrema importância para uma eficaz aplicabilidade deste meio de investigação. 
No presente exame, a escolha dos países não foi aleatória. Alguns critérios foram considerados para a seletividade das legislações estrangeiras verificadas. A Espanha, sem dúvida, em razão de ser o país mais avançado neste tema. Não apenas pela rapidez com que adotou em sua legislação interna regras relacionadas com a entrega vigiada, contados da data da assinatura da Convenção de Viena, mas também pela inovação e audácia, pois foi o Estado que deu um passo adiante, delineando contornos legislativos dantes nunca vistos acerca do instituto, com detalhes de sua aplicação, além da mantença das premissas já existentes.

Desta forma, o estudo relativo à entrega vigiada na Espanha será um pouco mais aprofundado, já que por meio desta legislação espanhola muitas soluções de aplicação da entrega vigiada podem ser extraídas.

Outro critério observado na seleção dos países, em consonância com o instituto, consistiu na conveniência de se eleger um país da América Latina, por causa da proximidade com o Brasil. E, dentre os países deste bloco, a Argentina foi escolhida em razão da maior preocupação da doutrina sulamericana com este meio de investigação.

Já a Itália, país de luta notória no enfrentamento do crime organizado, está em contínua inquietação no sentido de adotar novos métodos de investigação, o que favoreceu sua eleição. Além disso, a escolha da Itália ocorreu para demonstrar que muitos países não adotam a denominação entrega vigiada, embora utilizem métodos similares a este, previstos notadamente na legislação específica de combate ao tráfico de entorpecentes.

Dentro do sistema legal estrangeiro, a França foi inserida no rol de países examinados, pela distinção inovadora que faz entre entrega vigiada e entrega controlada. Diferenciação que passou a ser adotada por outros países. 
A Alemanha, outro país do bloco Europeu ${ }^{237}$, além de conferir um tratamento especial para o que chama de entrega controlada, foi selecionada tendo em vista diversas peculiaridades contidas em seu ordenamento para a aplicação do instituto, como a de não admitir o emprego da entrega vigiada (ou controlada) se não houver comprador no destino final.

Por último, não poderia ficar de fora da análise os Estados Unidos. Não apenas pela importância desse país no cenário mundial, mas também por sua guerra declarada ao crime organizado e ao terrorismo, notadamente após o conhecido episódio de 11 (onze) de setembro, o que guarda enorme pertinência com o meio investigatório em exame. Ainda, e por conta deste implacável enfrentamento ao crime organizado, os Estados Unidos acabam por permitir uma maior flexibilidade em relação às garantias fundamentais, de forma um pouco diversa dos demais países em estudo.

\subsubsection{Espanha}

A entrega vigiada passou a ter previsão no direito espanhol com a edição da Lei Orgânica 3, de 23 de dezembro de 1992, que introduziu o artigo 263 bis na Lei de Enjuiciamiento Criminal, norma esta alterada pela Lei Orgânica de 5/1999, de 13 de janeiro

${ }^{237}$ A Europol elaborou o Manual de Entregas Vigiadas na União Europeia, com instruções de como proceder na prática da entrega vigiada. Marta Gómez de Liaño Fonseca-Herrero menciona que "falar em entrega vigiada implica que na criminalidade organizada se serve, e se continuará a fazê-lo, da proteção constitucional do sigilo das comunicações e da intimidade, nos termos do artigo 18 da Constituição Federal. Quanto à questão da correspondência, preleciona que, com base no artigo 579 e seguintes da Ley de Enjuiciamiento Criminal, as autoridades, ao terem fortes suspeitas (sospechas racionales) de que em seu interior há oculto gênero de tráfico proibido, devem provocar sua detenção, abertura e exame". Lembra que, porém, tal prática não serve para comprovar culpabilidade e fazer prova substancial contra grupos organizados que exercem tráfico ilegal, daí por que a entrega vigiada, para Marta Gómez, constitui opção alternativa e complementar da detenção e abertura de correspondência, cuidando-se de uma exceção ao princípio da intervenção imediata ante a prática do delito. Referida autora relata inúmeras dificuldades decorrentes da abertura de correspondência suspeita, vez que o remetente e o destinatário dela podem ser falsos ou não localizados, o que deixaria a polícia e o juiz de instrução sem acusados reais contra os quais possam dirigir a acusação. Cita, ainda, que, no caso de apenas um destinatário, mais facilmente poderá alegar desconhecimento do conteúdo ilícito da correspondência, de sorte que contra esse só se captem indícios, tendo a jurisprudência dos Tribunais, nessas situações, tendido pela absolvição. Demais, tal descaracterizaria o conceito de crime organizado, vez que a investigação estaria dirigida a uma única pessoa (FONSECA-HERRERO, Marta Gómez de Liaño. Op. Cit., p.276). 
(aperfeiçoamento da ação investigadora relacionada com o tráfico ilegal de drogas e outras atividades ilícitas graves), em que se permite a circulação ou entrega de drogas ou outras substâncias psicotrópicas, sem que os policiais prendam imediatamente em flagrante.

Nota-se que a Convenção de Viena ocorreu em 1988 e em 1992 a Espanha vinha a alterar sua legislação pátria para fazer frente à nova realidade trazida pela referida Convenção, introduzindo o artigo 263 bis na Lei de Enjuiciamiento Criminal ${ }^{238}$, cuja redação, abaixo traduzida, está dividida em quatro pontos, estabelecendo que:

“Art. 263 bis, 1 - O juiz competente da instrução e o Ministério Fiscal, assim como os chefes das unidades orgânicas de polícia judicial, central ou de âmbito provincial, e seus comandantes superiores poderão autorizar a circulação ou entrega vigiada de drogas tóxicas, entorpecentes ou substâncias psicotrópicas, assim como de outras substâncias proibidas. Esta medida deverá ser adotada por meio de decisão fundamentada, na qual seja

238263 bis. 1 . El Juez de instrucción competente y el Ministerio Fiscal, así como los Jefes de las Unidades Orgánicas de Policía Judicial, centrales o de ámbito provincial, y sus mandos superiores podrán autorizar la circulación o entrega vigilada de drogas tóxicas, estupefacientes o sustancias psicotrópicas, así como de otras sustancias prohibidas. Esta medida deberá acordarse por resolución fundada, en la que se determine explícitamente, en cuanto sea posible, el objeto de autorización o entrega vigilada, así como el tipo y cantidad de la sustancia de que se trate. Para adoptar estas medidas se tendrá en cuenta su necesidad a los fines de investigación en relación con la importancia del delito y con las posibilidades de vigilancia. El Juez que dicte la resolución dará traslado de copia de la misma al Juzgado Decano de su jurisdicción, el cual tendrá custodiado un registro de dichas resoluciones. También podrá ser autorizada la circulación o entrega vigilada de los equipos, materiales y sustancias a los que se refiere el artículo 371 del Código Penal, de los bienes y ganancias a que se hace referencia en el artículo 301 de dicho Código en todos los supuestos previstos en el mismo, así como de los bienes, materiales, objetos y especies animales y vegetales a los que se refieren los artículos 332, 334, 386, 566, 568 y 569, también del Código Penal.2. Se entenderá por circulación o entrega vigilada la técnica consistente en permitir que remesas ilícitas o sospechosas de drogas tóxicas, sustancias psicotrópicas u otras sustancias prohibidas, los equipos, materiales y sustancias a que se refiere el apartado anterior, las sustancias por las que se haya sustituido las anteriormente mencionadas, así como los bienes y ganancias procedentes de las actividades delictivas tipificadas en los artículos 301 a 304 y 368 a 373 del Código Penal, circulen por territorio español o salgan o entren en él sin interferencia obstativa de la autoridad o sus agentes y bajo su vigilancia, con el fin de descubrir o identificar a las personas involucradas en la comisión de algún delito relativo a dichas drogas, sustancias, equipos, materiales, bienes y ganancias, así como también prestar auxilio a autoridades extranjeras en esos mismos fines. $\underline{\text {. }}$. El recurso a la entrega vigilada se hará caso por caso y, en el plano internacional, se adecuará a lo dispuesto en los tratados internacionales. Los Jefes de las Unidades Orgánicas de la Policía Judicial centrales o de ámbito provincial o sus mandos superiores darán cuenta inmediata al Ministerio Fiscal sobre las autorizaciones que hubiesen otorgado de conformidad con el apartado 1 de este articulo y, si existiese Procedimiento judicial abierto, al Juez de instrucción competente.4. La interceptación y apertura de envíos postales sospechosos de contener estupefacientes y, en su caso, la posterior sustitución de la droga que hubiese en su interior se llevarán a cabo respetando en todo momento las garantías judiciales establecidas en el ordenamiento jurídico, con excepción de lo previsto en el artículo 584 de la presente Ley. 
determinado explicitamente, tão quanto seja possível, o objeto da autorização ou entrega vigiada, assim como o tipo e a quantidade da substância que se trata. Para adotar estas medidas se levará em conta sua necessidade e os objetivos da investigação com relação à importância do crime e com as possibilidades de vigilância (monitoramento). O juiz que expedir a decisão trasladará cópia da mesma ao Juizado Decano de sua jurisdição, que terá guardado um registro destas decisões. Também poderá ser autorizada a circulação ou entrega vigiada dos equipamentos, materiais e substâncias que se referem o artigo 371 do Código Penal Espanhol, dos bens e ganhos aos quais se faz referência o artigo 301 de referido Código, assim como os bens, materiais, objetos e espécies animais e vegetais a que se referem os artigos 332, 334, 386, 566, 568 e 569, também do Código Penal Espanhol”.

“Art. 263 bis, 2 - Entender-se-á por circulação ou entrega vigiada a técnica consistente em permitir que remessas ilícitas ou suspeitas de drogas tóxicas, substâncias psicotrópicas ou outras substâncias proibidas, equipamentos, materiais e substâncias a que se refere o item precedente, e as substâncias pelas quais se tenham sido substituídas as anteriormente mencionadas, assim como os bens e os ganhos procedentes das atividades criminais tipificadas nos artigos 301 a 304 e 368 a 373 do Código Penal, circulem pelo território espanhol ou saem ou nele ingressem sem interferência obstativa da autoridade ou de seus agentes e sob sua vigilância (monitoramento), com a finalidade de descobrir ou de identificar as pessoas envolvidas no cometimento de algum delito relativo a ditas drogas, substâncias, equipamentos, materiais, bens e ganhos, assim como também prestar auxílio a autoridades estrangeiras com estes mesmos fins".

“Art. 263 bis, 3 - O recurso (a utilização) à entrega vigiada será feito caso por caso e, no plano internacional, se adequará ao disposto nos tratados internacionais. Os chefes das unidades orgânicas de polícia judicial, central ou de âmbito provincial e seus comandantes superiores prestarão conta imediata ao Ministério Fiscal acerca das autorizações que tenham concedido de acordo com o item 1 deste artigo e, se existir procedimento judicial aberto, ao juiz competente da instrução”. 
“Art. 263 bis, 4 - A interceptação e a abertura de encomendas postais suspeitas de conter entorpecentes e, neste caso, a posterior substituição da droga que houver em seu interior serão levadas a cabo, respeitando a todo o momento as garantias judiciais estabelecidas no ordenamento jurídico".

Como se vê a legislação espanhola sobre o tema é paradigma a ser utilizado por diversos Estados signatários das convenções no que tange à possibilidade de utilização da entrega vigiada. Em especial, para incrementar a legislação daqueles Estados signatários, que não dispõem de nenhum ordenamento jurídico interno para dar aplicabilidade à entrega vigiada.

O artigo 263 bis da Lei de Enjuiciamiento Criminal nos permite extrair diversas informações concernentes à entrega vigiada, especificadas e enumeradas abaixo e que revelam as principais características e procedimentos para a utilização da entrega vigiada.

1- A técnica na Espanha recebeu a denominação de circulação ou entrega vigiada.

2- A legislação espanhola define a entrega vigiada partindo da regra geral que consiste numa técnica de monitoramento das remessas ilícitas ou suspeitas. Porém, vai além ao prever que a vigilância se dará não apenas sobre substâncias entorpecentes, mas também sobre qualquer tipo de substância proibida ${ }^{239}$, incluindo drogas, bens procedentes de condutas delitivas, elementos de flora e fauna, moeda falsa, armas e munições.

3- Na Espanha, a entrega vigiada passa a ser tratada não só como instrumento internacional de auxílio ao combate ao crime organizado entre países, mas como um meio de obtenção de provas de uso interno, domiciliar. Isto porque o item 2 do artigo

\footnotetext{
${ }^{239}$ La regulación del art. 263 bis LECR contiene términos muy amplios: habla de remesas, es dicer, el envio de uns cosa de uns persona a otra, mediante cualquier médio, y sin restringirlo a paquetes postales; por otra parte, su ámbito material se extiende a cualesquiera sustancias, elementos de flora o fauna, equipos, materiales, bienes o ganancias cuyo tráfico se encuentre prohibido. Teniendo en cuenta dicha amplitud, la entrega vigilada regulada en el art. 263 bis LECR tiene abierta su aplicación a otras formas de criminalidad que en el futuro pretendan ampararse en la garantía del secreto de las comunicaciones para buscar su impunidad (MARTIN, Joaquin Delgado. La Criminalidad Organizada, J.M. Bosch editora Barcelona, 2001, p. 148).
} 
263 bis autoriza a permissão de circulação de remessas ilícitas que saiam ou entrem no Estado espanhol, mas também que circulem pelo território espanhol. Significa dizer, de um ponto a outro dentro do País.

4- A normatização espanhola previu a entrega vigiada na modalidade substituição (consoante possibilidade prevista na Convenção de Viena). Autoriza-se a circulação de remessas ilícitas ou suspeitas, mas também de remessas com produtos não mais ilícitos, pois substituídos por outros de conteúdo inofensivo. Temos, como exemplo, a substituição de cocaína por farinha, quando possível tal substituição sem despertar desconfianças das pessoas envolvidas na quadrilha perseguida. Dessa maneira, mesmo que o produto tenha deixado de ser ilícito, permite-se sua vigilância para atingir o objetivo final perseguido pelas autoridades.

5- A finalidade da entrega vigiada consiste em descobrir ou identificar as pessoas envolvidas no cometimento de algum delito relativo a drogas, substâncias, equipamento, materiais, bens e ganhos ilícitos ou suspeitos. Todavia, tal finalidade não se restringe ao alcance deste objetivo em âmbito interno, já que a legislação espanhola previu outra finalidade para entrega vigiada, qual seja, a de prestar auxílio a autoridades estrangeiras com estes mesmos fins. Percebe-se aqui o caráter internacional e cooperativo advindo das diversas convenções adotadas com o intuito de combater a criminalidade organizada de forma global.

6- $O$ item 1 do artigo 263 bis detalhou a parte procedimental da utilização da entrega vigiada. Na Espanha, diversas autoridades possuem legitimidade para autorizar a utilização da entrega: o juiz competente da instrução e o Ministério Fiscal, assim como os chefes das unidades orgânicas de polícia judicial, central ou de âmbito provincial, e seus comandantes superiores ${ }^{240}$. No entanto, é de se notar certa hierarquia entre os legitimados para conceder tal autorização, uma vez que os chefes

\footnotetext{
${ }^{240}$ Isabel Paz lembra que alguns doutrinadores acreditam equivocada a possibilidade de outros, além do juiz, poderem conceder a medida, já que essa, na prática, viola direitos fundamentais, especialmente o sigilo das comunicações postais, diante da abertura de pacotes que, por vezes, não contêm drogas (COGAN, Marco Antônio Pinheiro Machado e JOSÉ, Maria Jamile. Crime Organizado e Terrorismo na Espanha. In: Crime Organizado. Op. cit. p.144).
} 
das unidades orgânicas de polícia judicial, central ou de âmbito provincial e seus comandantes superiores deverão prestar conta imediata ao Ministério Fiscal acerca das autorizações que tenham concedido e, se existir procedimento judicial aberto, ao juiz competente da instrução. Há, dessa forma, uma superioridade do juiz competente e dos membros do Ministério Fiscal, que controlam a autorização dos demais legitimados. No caso a única menção de controle do juiz referida na legislação espanhola se refere à obrigação a este imposta de trasladar cópia de sua decisão ao Juiz Decano de sua jurisdição, que terá guardado um registro destas decisões.

7- A decisão que permite a sua utilização deverá ser fundamentada, prevendo, de forma expressa, o objeto da entrega vigiada, assim como o tipo e a quantidade da substância que se refere. Percebe-se a nítida preocupação do legislador em não dar azo à discricionariedade na utilização deste meio de investigação, para não permitir abusos na utilização da entrega vigiada.

8- A entrega vigiada somente poderá ser implantada ${ }^{241}$ analisando cada caso concreto e levando em consideração sua necessidade bem como os objetivos da investigação com relação à importância do crime e com as possibilidades de vigilância. Trata-se de mais uma preocupação do legislador, para que não haja uma banalização em sua utilização, o que elevaria, sobremaneira, a possibilidade de desvirtuamento do instituto em análise.

9- A Lei de Enjuiciamiento Criminal dispõe que a aplicação da entrega vigiada no plano internacional deverá ocorrer de forma adequada e compatível ao disposto nos tratados internacionais. A intenção do legislador foi de expor a necessidade de observância das regras dispostas nos tratados internacionais quando da utilização

\footnotetext{
${ }^{241}$ De acordo com o relatório da Fiscalização Geral do Estado espanhol, de 1993, são condições de aplicação da técnica da entrega vigiada: a) impossibilidade de concessões genéricas da entrega vigiada, devendo ser analisado cada caso; b) que seja pouco provável ou muito difícil a descoberta de membros da organização investigada, ou a obtenção de provas de sua participação nas atividades de grupo; c) o crime objeto da investigação há de ser um fato grave de tráfico organizado (artigo 263.1 da Ley de Enjuiciamiento Criminal) (COGAN, Marco Antônio Pinheiro Machado e JOSÉ, Maria Jamile. Crime Organizado e Terrorismo na Espanha. In: Crime Organizado. Op. cit. p.144).
} 
efetiva da entrega vigiada entre países. E não poderia ser de outra forma, até porque o único ordenamento em comum e que pode regular a aplicação de forma internacional de um instituto entre dois países deve, regra geral, estar representado por um texto internacional. Porém, deixou de mencionar qual seria a solução a ser adotada caso houvesse conflito entre legislações internas de dois países que regulem a aplicação da entrega vigiada de forma diversa.

10- A última inovação revelada pela lei espanhola está na previsão da entrega vigiada para os casos de correspondências postais, pois até então nenhuma legislação interna havia previsto expressamente a possibilidade de monitoramento através deste meio. Todavia, ela pode perfeitamente ocorrer se pegarmos o exemplo de organização criminosa que negocia diamantes, facilmente remetidas por meio de encomendas postais. Nessa situação o legislador espanhol também prevê a possibilidade de substituição da remessa ilícita, sem a percepção dos envolvidos no ilícito. E novamente preocupado com a excepcionalidade desse meio de obtenção de prova houve por bem deixar consignado, de forma expressa, a necessidade de observância das garantias estabelecidas no ordenamento jurídico.

\subsubsection{Argentina}

$\mathrm{Na}$ Argentina, a Lei $\mathrm{n}^{\circ} 24.424$ recepcionou a entrega vigiada como nova técnica de investigação e repressão contra o narcotráfico, somando-se a outras formas de investigação, como o denominado 'agente encubierto'.

$\mathrm{Na}$ verdade, o artigo 11 da lei $\mathrm{n}^{\circ} 24.424$ incorporou a entrega vigiada por meio de uma nova redação do parágrafo único, do artigo 33, da Lei no 23.737 (Código Penal Argentino), dispondo que:

“Artigo 33 - O juiz da causa poderá autorizar a autoridade de prevenção que postergue a detenção de pessoas ou o sequestro de entorpecentes quando estime que a execução imediata de tais medidas possa comprometer o êxito da investigação. O juiz poderá, 
inclusive, suspender a interceptação no território argentino de uma remessa ilícita de entorpecentes e permitir sua saída do país, quando tiver segurança de que será vigiada pelas autoridades judiciais do país de destino. Essa medida deverá ocorrer por decisão fundamentada, fazendo constar, tanto quanto possível, a qualidade e quantidade da substância vigiada, como também seu peso ${ }^{242,}$.

Assim, o artigo 11 da Lei 24.424, de 9 de janeiro de 1995, permite ao juiz autorizar a postergação da detenção de pessoas ou da interceptação das substâncias tóxicas com a finalidade de garantir o êxito da investigação ${ }^{243}$.

De se observar a prudência adotada pelo legislador em permitir a utilização da entrega e sua consequente autorização para continuar circulando para outro país, quando tiver certeza que a remessa ilícita estará sendo monitorada pelo país de destino.

A segunda parte do parágrafo inserido no artigo 33 dispõe que a entrega vigiada deverá ser determinada por decisão fundada, fazendo constar, sempre que possível, a qualidade e a quantidade da substância vigiada, assim como seu peso.

\subsubsection{Itália}

Na Itália, o 'Decreto Del Presidente Della Repubblica' n’ 309, de 9 de outubro de 1990, institui o "testo unico delle leggi in materia di disciplina degli stupefacenti e sostanze psicotrope, prevenzione, cura e riabilitazione dei relativi stati di tossicodipendenza".

\footnotetext{
${ }^{242}$ Tradução livre do texto original: "El juez de la causa podrá autorizar a la autoridad de prevención que postergue la detención de personas o el secuestro de estupefacientes cuando estime que la ejecución inmediata de dichas medidas puede comprometer el éxito de la investigación. El juez podrá incluso suspender la interceptación en territorio argentino de una remesa ilícita de estupefacientes y permitir su salida del país, cuando tuviere seguridades de que será vigilada por las autoridades judiciales del país de destino. Esta medida deberá disponerse por resolución fundada, haciéndose constar, en cuanto sea posible, la calidad y cantidad de la sustancia vigilada como asi también su peso".

${ }^{243}$ ZAFFARONI, E.R. Política criminal em matéria de drogas em la República Argentina, em La Actual política criminal sobre drogas. Uma perspectiva comparada (coord. Díez Ripollés Y Laurenzo Copello), Valencia, 1193, p.135.
} 
Trata-se de um decreto específico para regular e disciplinar a questão das drogas na Itália, bem como a cooperação internacional no combate a delitos relacionados com substâncias entorpecentes.

Desta maneira, não há dispositivos no Código Penal ou Processual Penal italiano acerca do tema da entrega vigiada, uma vez que essa matéria encontra-se regulada por texto especial, denominado 'testo único', supracitado.

Nesse decreto (com 136 artigos no total, além de uma tabela anexa com diversas substâncias psicotrópicas consideradas ilícitas) os dispositivos relacionados com o tema ora estudado são os artigos 73 e o $74^{244}$, que prevêem os crimes relacionados à venda,

${ }^{244}$ Art. 73 Spaccio, produzione,Traffico Produzione e traffico illecito di sostanze stupefacenti . 309/90

1. Chiunque senza l'autorizzazione di cui all'art. 17, coltiva, produce, fabbrica, estrae, raffina, vende, offre o mette in vendita, cede o riceve a qualsiasi titolo, distribuisce, commercia, acquista, trasporta, esporta, importa, procura ad altri, invia, passa o spedisce in transito, consegna per qualunque scopo o comunque illecitamente detiene, fuori dalle ipotesi previste dagli articoli 75 e 76, sostanze stupefacenti o psicotrope di cui alle tabelle I e III previste dall'art. 14, è punito con la reclusione da otto a venti anni e con la multa da lire cinquanta milioni a lire cinquecento milioni.

2. Chiunque, essendo munito dell'autorizzazione di cui all'art. 17, illecitamente cede, mette o procura che altri metta in commercio le sostanze o le preparazioni indicate nel comma 1, è punito con la reclusione da otto a ventidue anni e con la multa da lire cinquanta milioni a lire seicento milioni.

3. Le stesse pene si applicano a chiunque coltiva, produce o fabbrica sostanze stupefacenti o psicotrope diverse da quelle stabilite nel decreto di autorizzazione.

4. Se taluno dei fatti previsti dai commi 1, 2 e 3 riguarda sostanze stupefacenti o psicotrope di cui alle tabelle II e IV previste dall'art. 14, si applicano la reclusione da due a sei anni e la multa da lire dieci milioni a lire centocinquanta milioni.

5. Quando, per i mezzi, per la modalità o le circostanze dell'azione ovvero per la qualità e quantità delle sostanze, i fatti previsti dal presente articolo sono di lieve entità, si applicano le pene della reclusione da uno a sei anni e della multa da lire cinque milioni a lire cinquanta milioni se si tratta di sostanze stupefacenti o psicotrope di cui alle tabelle I e III previste dall'art. 14, ovvero le pene della reclusione da sei mesi a quattro anni e della multa da lire due milioni a lire venti milioni se si tratta di sostanze di cui alle tabelle II e IV.

6. Se il fatto è commesso da tre o più persone in concorso tra loro, la pena è aumentata.

7. Le pene previste dai commi da 1 a 6 sono diminuite dalla metà a due terzi per chi si adopera per evitare che l'attività delittuosa sia portata a conseguenze ulteriori, anche aiutando concretamente l'autorità di polizia o l'autorità giudiziaria nella sottrazione di risorse rilevanti per la commissione dei delitti. 
produção e associação ao tráfico de drogas e os artigos 97 e 98 que dispõem sobre o retardamento ou omissão do ato de captura, sequestro ou arresto, incluindo a colaboração internacional. Estes últimos dois artigos são integrantes do Capítulo III, que trata das operações policiais e destinação de bens e valores sequestrados ou confiscados.

Importante mencionar que a norma italiana em nenhum momento cita, de forma textual, a expressão "entrega vigiada", sendo a previsão deste instituto na Itália uma construção doutrinária, a partir dos artigos 73 e 74 e 97 e 98 do Decreto Presidencial no $309 / 90$.

Segundo o artigo 98 do D.P.R. n $309 / 90^{245}$ é prevista a possibilidade de atraso na prisão em flagrante, quando se verificar o transporte de substâncias entorpecentes,

Art. 74 Associazione a deinquere finalizzata allo spaccio Art. 74 309/90 Associazione finalizzata al traffico illecito di sostanze stupefacenti o psicotrope

1. Quando tre o più persone si associano allo scopo di commettere più delitti tra quelli previsti dall'art. 73, chi promuove, costituisce, dirige, organizza o finanzia l'associazione è punito per ciò solo con la reclusione non inferiore a venti anni.

2. Chi partecipa all'associazione è punito con la reclusione non inferiore a dieci anni.

3. La pena è aumentata se il numero degli associati è di dieci o più o se tra i partecipanti vi sono persone dedite all'uso di sostanze stupefacenti o psicotrope.

4. Se l'associazione è armata la pena, nei casi indicati dai commi 1 e 3 , non può essere inferiore a ventiquattro anni di reclusione e, nel caso previsto dal comma 2, a dodici anni di reclusione. L'associazione si considera armata quando i partecipanti hanno la disponibilità di armi o materie esplodenti, anche se occultate o tenute in luogo di deposito.

5. La pena è aumentata se ricorre la circostanza di cui alla lettera e) del comma 1 dell'art. 80.

6. Se l'associazione è costituita per commettere i fatti descritti dal comma 5 dell'art. 73, si applicano il primo e il secondo comma dell'art. 416 del codice penale.

7. Le pene previste dai commi da 1 a 6 sono diminuite dalla metà a due terzi per chi si sia efficacemente adoperato per assicurare le prove del reato o per sottrarre all'associazione risorse decisive per la commissione dei delitti.

8. Quando in leggi e decreti è richiamato il reato previsto dall'art. 75 della legge 22 dicembre 1975, $n$. 685 , abrogato dall'art. 38, comma 1, della legge 26 giugno 1990, n. 162, il richiamo si intende riferito al presente articolo

${ }^{245}$ Art. 98

Ritardo o omissione degli atti cattura, di arresto o di seqüestro

Collaborazione internazionale

1. Láutorita 'giudiziaria puo', com decreto motivato, ritardare lémissione o disporre che sai ritardata lésecuzione di provvedimenti di cattura, arresto o seqüestro quando sai necessario per acquisire rilevanti elementi probatori ovvero per l'individuazione o la cattura dei responsabili dei delitti di cui agli articolo 73 e 74.

2. Per gli stessi motivi gli ufficialu di polizia giudiziaria addeti alle unita'specializzate antidroga, nonche'le autorita'doganali, possono omettere o ritardare gli atti di rispettiva competenza dandone immediato avviso, anche telefônico, all'autorita'giudiziaria, che puo'disporre diversamente, ed al Servizio centrale antidroga per il necessario coordinamento anche in ambito internazionale. L'autorita'procedente trasmette motivato rapporto all'autorita'giudiziaria entro quarantotto ore. 
para que se possa adquirir um maior número de elementos probatórios relevantes para a individualização e captura dos responsáveis pelos delitos previstos nos artigos 73 e 74.

Permite, em tal situação, que a autoridade judicial, por meio de despacho motivado, deixe de ordenar a prisão ou captura das substâncias entorpecentes.

Segue o texto da lei italiana ${ }^{246}$ : "A autoridade judicial pode, por decreto motivado, atrasar a emissão ou dispor que seja atrasada a execução de um procedimento de captura, arresto ou sequestro quando seja necessário para adquirir elementos probatórios relevantes para a individualização e captura dos delitos a que se referem os artigos 73 e 74 do D.P.R. no 309/90”. Talvez essa previsão possa guardar mais proximidade com a ação controlada do que com a entrega vigiada, muito embora a doutrina italiana trate a questão preferencialmente como sendo o segundo instituto.

Os artigos $97^{247}$ e 98 do texto único revelam meios excepcionais de obtenção de provas no combate ao tráfico ilícito de drogas.

3. L'autorita'giudiziaria impartisce allá polizia giudiziaria lê disposizioni di massima per il controllo degli sviluppi dell'attivita'criminosa, comunicando i provvedimenti adottati all'autorita'giudiziaria competente per il luogo in cui l'operazione deve concludersi ovvero per il luogo attraverso il quale si prevede sai effettuato il transito in uscita dal território dello Sato, ovvero quello in entrata nel território dello Satto, delle sostanze stupefacenti o psicotrope e di quelle di cui all'articolo 70.

4. Nei casi di urgenza lê disposizioni di cui ai commi l, 2 e 3 possono essere richoeste od impartite anche oralmente, ma il relativo provvedimento deve essere emesso entro lê sucessive ventiquattro ore.

${ }^{246}$ Trecho original do texto legal: "La autoridad judicial puede, por decreto motivado, retrasar la emisión o disponer que sea retrasada la ejecución de un procedimiento de captura, arresto o secuestro cuando sea necesario para adquirir elementos probatórios relevantes para la individualización y captura de los responsable de los delitos a los que se refieren los arts. 73 e 74 do D.P.R. $n^{\circ} 309 / 90 "$.

${ }^{247}$ Art. 97 Attivita'sotto copertura (1- Fermo il disposto dell'articolo 51del códice penale, non sono punibili gli ufficiali di polizia giudiziaria addetti alle unita'specializzate antidroga, i quali, al solo fine di acquisire elementi di prova in ordine ai delitti previsti dal presente texto único ed in esecuzione di operazioni anticrimine specificatamente disposte della Direzione centrale per i servizi antidroga o, sempre dintesa com questa, dal questore o dal comandante provinciale dei Carabinieri o della Guardiã di finanza o dal comandante del núcleo di polizia tributaria o dal direttore della Direzione investigativa antimafia di cui all'articolo 3 del decreto-legge 29 ottobre 1991, $n$ 345, convertito, com modificazioni, dalla legge 30 dicembre 1991, $n 410$, anche per interposta persona, acquistano, ricevono, sostituiscono od occultano sostanze stupefacenti o psocotrope o compiono attivita 'prodromiche e strumentali.

2. Per lê stesse indagini di cui all comma 1 , gli ufficiali ed agenti di polizia giudiziaria possono utilizzare documenti, identita'o indicazioni di copertura anche per attivare o entrare in contatto com soggetti e siti nelle reti di comunicazione, informandone il pubblico ministério al piu'presto e comunque entro lê quarantotto ore successive all'inizio delle attivita'.

3. Dell'esecuzione delle operzaioni di cui al comma 1 e'data immediata e dettagliata comunicazione allá Direzione centrale per i servizi antidroga ed all'autorita'giudiziaria, indicando, se necessário o se richiesto, 
O artigo 97 regula a aquisição simulada de drogas (fictus emptor) como meio de provocação delitiva ilícita, limitando a condição de agente provocador para os agentes de polícia judiciária adstritos às unidades especiais antidrogas e exigindo um completo controle da autoridade judicial do início ao fim da atividade provocadora.

A doutrina italiana estabeleceu com segurança os limites entre a norma do artigo 97 e a do artigo 98. Enquanto na entrega vigiada (artigo 98) se regula uma atividade de mera omissão e controle, na aquisição simulada (artigo 97) o agente provocador que finge adquirir uma quantidade de entorpecentes entra verdadeiramente em ação, não se limitando a ter um comportamento omissivo ${ }^{248}$.

Consoante Cabada “a norma italiana do 'Testo Unico' (artigo 98 - item 3) prevê que a autoridade judicial que determina a autorização para a entrega vigiada deverá comunicar as disposições adotadas à autoridade judicial competente do lugar em que as operações devam se concluir, ao juiz do lugar através do qual se preveja que será efetuado o trânsito de saída do território do Estado e também à autoridade judicial competente do lugar de entrada no território do Estado das substâncias entorpecentes ou psicotrópicas"249.

Este item 3 do artigo 98, que trata especificamente de procedimento previsto ao que seria comumente conhecido como entrega vigiada, contempla a possibilidade de que a droga circule sob controle judicial, através do território do Estado e nele saia ou ingresse.

anche il nominativo dell'ufficiale di polizia giudiziaria responsabiile dell'operazione, nonche 'il nominativo delle eventuali interposte persone impiegate.

4.Gli ufficiali di polizia giudiziaria possono avvalersi di ausiliari ed interposte persone, ai quali si estende la causa di non punibilita'di cui al presente articolo. Per l'esecuzione delle operazioni puo'essere autorizzata l'utilizzazione temporanea di beni mobili ed imobili, nonche'di documenti di copertura secondo lê modalita'stabilite com decreto del Ministro dellínterno, di concerto con il Ministro della giustizia e con gli altri Ministri interessati.

5. Chiunque, nel corso delle operazioni sotto copertura di cui al comma 1, indebitamente rivela ovvero divulga $i$ nomi degli ufficiali o agenti di polizia giudiziaria che effettuano lê operazioni stesse, e'punito, salvo che il fatto costituisca piu'grave reato, con la recluisone da due a sei anni)).

${ }^{248}$ Maglie, C. de: L'agente provocatore, p. 268 e seguintes e 384 e seguintes.

249 CABADA, Gumersindo Guinarte. La Circulacion o entrega vigilada de drogas. Cuadernos de política criminal. Edersa Editoriales, 1995. Madrid, p.12 
O artigo 98 ainda prevê, ao lado da hipótese de autorização judicial (98 item 1) uma outra possibilidade de autorização de cunho administrativo (98 - item 2). Somente para esta última, em qualquer caso, haverá um estrito controle judicial (seja do Juiz ou do Ministério Fiscal, segundo seu âmbito de competências), estabelecendo que a autoridade policial deverá prestar conta imediatamente, inclusive via telefônica, para a autoridade judicial, que poderá revogar a autorização ${ }^{250}$.

Assim, são legitimados ${ }^{251}$ para autorizar o retardamento da execução de um procedimento de captura, arresto ou sequestro (conhecido pela doutrina italiana de entrega vigiada) a autoridade judicial, através de despacho motivado (e em regra escrito) e também as autoridades policiais ligadas às unidades especiais antidrogas, porém sob a supervisão e mediante a comunicação imediata para a autoridade judicial (inclusive por telefone), que analisará a autorização, podendo mantê-la ou revogá-la.

No caso de autorização por autoridade policial, o procedimento correspondente deve ser emitido dentro das 48 horas seguintes.

Prevê, também, o decreto italiano que nos casos de urgência para utilização dos instrumentos contidos nos artigos 97 e 98 as autorizações podem ser requeridas, excepcionalmente, de forma oral. Mas, de toda forma, o correspondente procedimento deve ser iniciado nas 24 horas sucessivas à referida autorização.

\subsubsection{França}

\footnotetext{
${ }^{250}$ PRADEL, J. trafic de drogue, p. 231.

${ }^{251}$ El artículo 98 del Testo unico sobre drogas regula los supuestos de retraso ou omisión de los actos de captura, de arresto y de incautación y la colaboración internacional. Según su texto, la autoridad judicial y, excepcionalmente, la Policía Judicial adscrita a los servicios antidroga podrán, motivadamente, retardar la emisión o la ejecución de las ordenes de captura, de arresto o de incautación cuando ello se a necessario para obtener relevantes elementos probatórios o para identificar o facilitar la detención de personas implicadas en delitos de tráfico de drogas. (CABADA, Gumersindo Guinarte. La Circulación o entrega vigilada de drogas. Cuadernos de política criminal. Edersa Editoriales, 1995. Madrid, p.9).
} 
Na França, a Lei $n^{\circ}$ 91-1264, de 19 de dezembro de $1991^{252}$, relativa ao fortalecimento da luta contra o tráfico de entorpecentes contemplou nova redação aos regulamentos relativos a essa matéria. Referida lei introduz novo texto ao artigo 627.7 do Código de Saúde Pública e no artigo 67 bis do Código de Aduanas.

Todavia, no direito francês as normas introduzidas pela Lei 91-1264 não abordam somente a entrega vigiada (livraisons surveillées), mas também um amplo catálogo de condutas de provocação delitiva em matéria de tráfico de drogas.

O parágrafo primeiro do artigo 627.7 do Código de Saúde Pública da França prevê as condições relativas à entrega vigiada. Já o parágrafo segundo passa a legalizar as operações de compra.

Essas figuras excepcionais de atuação no combate ao tráfico de drogas já haviam sido reconhecidas em várias ocasiões anteriores pela jurisprudência da Corte de Cassação francesa.

O parágrafo primeiro do artigo 627.7 do Código de Saúde Pública autoriza os oficiais e os agentes da polícia judicial sob sua autoridade, depois de ter informado ao Procurador da República, a proceder à vigilância dos envios de substâncias ou plantas classificadas como entorpecentes ou produtos obtidos resultantes do cometimento de infrações dessa natureza, com o fim de constatar as condutas previstas nos três primeiros parágrafos do artigo 627.7, de identificar seus autores e cúmplices e de efetuar as apreensões previstas na lei. $^{253}$

${ }^{252}$ En Francia, la ley del 19 de diciembre de 1991 intentó reforzar las normas relativas a la lucha contra el tráfico de estupefaciente incluyendo en el art. $1^{\circ}$ del Código de Salud Pública el art. L 627-7, reemplazado por el art. 706.32 del Código de Procedimiento Penal, tal como fue establecido por la ley del 16 de diciembro de 1992 (92-1336) (MONTOYA, Mario Daniel. Informantes y Técnicas de Investigación Encubiertas. Análisis Constitucional y Procesal Penal, $2^{\mathrm{a}}$ edição, Editora Ad Hoc, Buenos Aires).

${ }^{253}$ Sobre o procedimento: El art. 706.32, paragrafo $1^{\circ}$ del Código de Procedimiento Penal permite a los oficiales de la policía judicial, proceder a la vigilancia del despacho de substancias o plantas clasificadas como estupefacientes o de productos resultado de la comisión de las infracciones previstas por los arts. 222-34 a 22238 del Código Penal.

Las operaciones se llevam a cabo luego de haber realizado el correspondiente informe al procurador de la República y se consideran lícitas en el caso que tengan como finalidad comprobar las infracciones previstas por 
Por sua vez, no parágrafo primeiro do artigo 67 bis do Código de Aduanas existe idêntica autorização para os agentes da aduana, habilitados pelo Ministro encarregado da aduana, nas condições fixadas pelo Decreto n 92-696, de 20 de julho de 1992.

No caso de aplicação da técnica de monitoramento previsto no Código de Aduanas, além dos fins previstos no Código de Saúde Pública soma-se o de averiguar as infrações aduaneiras de importação e exportação de substâncias ou plantas classificadas como entorpecentes $^{254}$.

A legislação francesa faz distinção inovadora (ao menos de denominação) entre entrega vigiada e entrega controlada.

Para Montoya "a entrega vigiada consiste na atividade puramente passiva da autoridade da aduana ou da polícia judicial, que se limitam a seguir e documentar sem intervir na transação ilícita do grupo criminoso. Por outro lado, a entrega controlada integra a conduta ativa do funcionário público que intervém nos diversos movimentos da mercadoria ilícita (aquisição, transporte, detenção), também assumindo pessoalmente o encargo de conservação. Em tais casos os agentes cumprem, por ocasião do serviço, atos repelidos pela lei" 255 .

Nesse sentido, Pradel aponta as diferenças entre os institutos, ao observar que "a doutrina francesa claramente diferencia as hipóteses de entrega vigiada (livraisons surveillées), consideradas meras omissões atípicas, das suposições de entrega controlada (livraisons contrôlées) ou provocação de ação e infiltração em uma rede ou organização, autênticos comportamentos típicos de tráfico de entorpecentes ou de cumplicidade com estes delitos"256.

los arts. 222-34 a 222-38 del Código Penal para lo cual se deberá identificar a los autores y cúmplices de tales ilícitos y efectuar las incautaciones.

${ }^{254}$ CABADA, Gumersindo Guinarte. La Circulación o entrega vigilada de drogas. Cuadernos de política criminal. Edersa Editoriales, 1995. Madrid, p.10.

${ }^{255}$ MONTOYA, Mario Daniel. Informantes y Técnicas de Investigación Encubiertas. Análisis Constitucional y Procesal Penal, $2^{\text {a }}$ edição, Editora Ad Hoc, Buenos Aires. p.333.

${ }^{256}$ PRADEL, J., Trafic de drogue, p. 231. 
Ainda, Herve Lasportes (na época comissário da polícia francesa antinarcotráfico) também atentou para a diferença que ocorre na legislação deste País, assinalando que, na entrega vigiada, a mercadoria ilegal é objeto de uma vigilância passiva por parte dos policiais. Já a entrega controlada é aquela em que se recorre a agentes infiltrados que participam diretamente da operação. ${ }^{257}$

Por fim, de se ressaltar a observação de $\operatorname{Pradel}^{258}$ : “Na França a doutrina estima que o agente encarregado de vigiar as entregas de drogas se mantém em um papel puramente passivo, de simples observador, que não poderia incorrer na sua responsabilização penal enquanto não existir norma de autorização das entregas vigiadas. Sua conduta omissiva não seria considerada nenhum delito dos descritos no artigo 62 do Código Penal, em que se penaliza a omissão do dever de denunciar crimes. Certamente o Código de Processo Penal impõe a todo funcionário o dever de denunciar perante a autoridade judicial as infrações de que tenha conhecimento no exercício de suas funções, mas o descumprimento desta norma não pode levar a sanção penal alguma."

\subsubsection{Alemanha}

Diversas legislações estrangeiras recepcionaram a entrega vigiada, assim como o direito alemão. Durante o Congresso de compatibilização de leis pela luta contra a narcocriminalidade, ocorrido em agosto de 1993, em Buenos Aires, o fiscal da República Federal da Alemanha (Rainer Pfaff ${ }^{259}$ ) expôs que por entrega controlada se compreende o

\footnotetext{
${ }^{257}$ Publicação do Parlamento Latino Americano, p.48.

${ }^{258}$ PRADEL, J., Trafic de drogue, p. 231.

259 Na obra de Mario Daniel Montoya, o autor revela alguns problemas práticos apontados por Rainer Pfaff na utilização da entrega controlada na Alemanha, trecho transcrito a seguir: "El fiscal Pfaff explicó que la Administración de Aduanas en Francfort informó acerca de los seguintes problemas prácticos en lo que hace a las entregas controladas: 1) cuando hay incautaciones sorpresivas no es posible el seguimiento controlado por falta de tiempo hasta el vuelo de conexión; 2) en lo que hace a la obtención de la autorización fiscal, su tramitación lleva demasiado tiempo; 3) no se pueden obtener a tiempo la aprobación y las garantías del país de destino; 4) debido a la escasez de tiempo o de personal, las autoridades del país de destino no pueden poner a disposición grupos de vigilancia; 5) si en el país de destino existiera otro sistema legal, o si las entregas controladas fueran consideradas ilegales, la cooperación se hace muy difícil.
} 
transporte ilegal de entorpecentes ou de outras mercadorias que, apesar de ser conhecido das autoridades de repressão, momentaneamente não é impedido ${ }^{260}$. Essa entrega controlada tem o propósito de conhecer os compradores e organizadores do tráfico ilegal de entorpecentes.

Na Alemanha, o corpo legislativo que rege a disciplina da entrega vigiada se encontra nos lineamentos para o procedimento penal e no procedimento de imposição de multas, conhecido como RiStBV ${ }^{261}$. Nesse País a denominação utilizada é entrega controlada e não entrega vigiada.

O conceito de entrega ou trânsito controlado, encartado no artigo 29 da $\mathrm{RiStBV}^{262}$, pode ser entendido como o transporte ilegal de entorpecentes de um país até uma terceira nação, manobra que é vigiada pelas autoridades correspondentes.

Consta, ainda, na lei alemã que exportação controlada significa o transporte ilegal vigiado desde o país até o exterior e importação controlada consiste no transporte ilegal vigiado desde o exterior até o ingresso no país.

As entregas controladas possibilitam às autoridades de repressão apreender no país de destino, não somente os transportadores, como também os compradores e no país de origem, os organizadores.

Especialmente tal possibilidade de atingir os mentores das organizações de narcotraficantes que faz da entrega controlada um instrumento indispensável na luta contra a criminalidade organizada.

\footnotetext{
${ }^{260}$ EDWARDS, Carlos Enrique. El arrepentido, el agente encubierto y la entrega vigilada. Modificación a la Ley de Estupefacientes. Análisis de la ley 24.424, Editora Ad Hoc, Buenos Aires.

${ }^{261}$ MONTOYA, Mario Daniel. Informantes y Técnicas de Investigación Encubiertas. Análisis Constitucional y Procesal Penal, $2^{a}$ edição, Editora Ad Hoc, Buenos Aires. p.337.

${ }^{262}$ Por entrega controlada se entende "el transporte ilegal de estupefacientes desde el exterior, por el país hacia uns tercera nación, maniobra que es vigilada por las autoridades correspondientes. La exportación controlada significa el transporte ilegal vigilado desde el país hacia el exterior, por su parte la importación controlada es el transporte ilegal vigilado desde el exterior hacia el país" (MONTOYA, Mario Daniel. Informantes y técnicas de investigación encubiertas, p. 337).
} 
Em que pese o ordenamento alemão aceitar a utilização da prática da entrega vigiada, inserindo-a de forma expressa em sua legislação pátria, pouca ou quase nenhuma utilidade possui tal legislação, porque retrata apenas a característica mais óbvia do instituto, que é a vigilância da remessa ilícita.

Na Alemanha, a principal dificuldade enfrentada pela doutrina era a de saber se o direito de tolerar os transportes controlados se compatibilizava com o princípio da legalidade do seu direito processual penal, porquanto o Estado tem a obrigação de reprimir os atos delitivos, com a correspondente problemática para a polícia de incorrer no delito de “encobertamento" no caso de omitir a persecução correspondente.

Segundo a legislação alemã ${ }^{263}$ as entregas controladas levam em conta as seguintes características:

a) deve ser utilizada somente no enfrentamento de delitos graves;

b) não deve ser realizada uma entrega controlada sem que haja compradores;

c) deve ser garantida a possibilidade de detenção ou de perseguição em qualquer momento;

d) são proibidas as vendas encobertas com perigo de desaparição das drogas;

e) a elas se aplica o princípio da subsidiariedade.

\subsubsection{Estados Unidos}

As leis americanas são mais flexíveis quanto à utilização da entrega vigiada e, assim como na Alemanha, utilizam a denominação de entrega controlada.

${ }^{263}$ Op. Cit. p. 121. 
Não obstante referida flexibilização, torna indispensável a observância de uma série de requisitos formais dispostos em diversos procedimentos com os quais se leva a cabo a prática desse tipo de técnica, o que ocorre especialmente no que tange às ordens para abrir pacotes, instalar equipamentos de vigilância, dispositivos de gravação ou fiscalização de mercadorias.

É necessário que a entrega, ocultamento, transporte e recepção se tipifiquem como delitos de acordo com o ordenamento interno, assim como também que cada Estado disponha de um organismo que seja responsável pela vigilância para se levar a termo as manobras imprescindíveis que circundam a entrega vigiada.

No direito americano a expressão "entrega controlada" adota basicamente a definição da entrega vigiada da Convenção de Viena, significando a técnica de permitir que remessas ilícitas ou suspeitas de substâncias controladas ou substâncias substituídas por um ou mais Estados, com o consentimento e sob a supervisão das autoridades competentes, tendo o objetivo de identificar as pessoas envolvidas, com a intenção de cometer delitos contra a lei de narcóticos ou produtos químicos referidos no artigo $3^{\circ}$, parágrafo $1^{\circ}$, da Convenção das Nações Unidas contra o tráfico ilícito de drogas e substâncias psicotrópicas.

Na visão de Montoya: “Com o propósito de investigar o transporte de substâncias controladas, qualquer oficial de polícia ou agente da aduana autorizado ou qualquer outra agência de investigação devidamente autorizada poderá efetuar uma entrega controlada, seja através da substituição da mercadoria monitorada ou, ainda, permitindo que parte desta permaneça em aeronaves, barcos, veículos, pacotes postais como se tivesse existido uma entrega como pretendeu o remetente" 264 .

A autorização para a entrega vigiada se estenderá às investigações ${ }^{265}$ que abarquem um ou mais países, através de uma petição ou um acerto entre as autoridades.

\footnotetext{
${ }^{264}$ MONTOYA, Mario Daniel. Informantes y Técnicas de Investigación Encubiertas. Análisis Constitucional y Procesal Penal, $2^{\text {a }}$ edição, Editora Ad Hoc, Buenos Aires, p. 339.

${ }^{265}$ Também na legislação dos Estados Unidos se legitima a atuação do agente provocador através da figura jurídica denominada "entrapment". Figura esta criada jurisprudencialmente e que agora tem reconhecimento
} 


\subsection{Alguns pontos comparados entre os países}

Com relação à autorização para o emprego da entrega vigiada, cada país determina a autoridade (ou autoridades) competente para sua concessão. Na Espanha, a Ley de Enjuiciamiento Criminal dispõe que o juiz da instrução, o Ministério Fiscal, bem como os chefes das unidades orgânicas da Polícia Judicial, central ou de âmbito provincial, poderão autorizar a medida, dependendo do momento e da situação.

Observa Marta Gómez de Liaño que “esse esquema de competência tripartite espanhol coincide com o articulado pela República de Portugal, no artigo 61.3 do Decreto 15/1993, de 22 de janeiro, que confere faculdade autorizadora não somente ao órgão judicial, mas também ao Ministério Fiscal e os funcionários policiais"266.

Coincidência parcial existe entre a previsão espanhola e a regulamentação francesa e italiana. Na Itália, o art. 98 do Decreto do Presidente da República 309/1990, de 09 de outubro, outorga competência para dispor sobre a entrega vigiada ao órgão judicial e às unidades especiais antidroga da Polícia Judicial.

Na França exige-se autorização do Procurador da República ou da Autoridade Judicial, conforme art. 627.7 do Código de Saúde Pública, com a modificação operada pela lei 91/1264, de 19 de dezembro e o artigo 706/80 da lei no 204-2004, de 09 de março.

Diferentemente, a Argentina reserva exclusivamente aos órgãos jurisdicionais a competência para ajustar operações de entrega vigiada, conforme disposto no art. 11 da lei 24.072 de 1992.

legal no Código Penal. Este instituto jurídico admite a licitude da indução realizada por um agente da polícia em âmbito de uma série de delitos denominados "delitos sem vítima" e "delitos de encontro", todos relacionados com a criminalidade do vício (prostituição, jogos ilícitos e tráfico de drogas).

${ }^{266}$ (FONSECA-HERRERO, Marta Gómez de Liaño. Criminalidad Organizada y medios extraordinarios de investigación. Editorial Colex, Madrid: 2004, p. 312/313) 
Gumersindo Guinarte Cabada ${ }^{267}$ traça um paralelo entre a legislação italiana e a francesa no tocante à técnica da entrega vigiada. Constata o autor que "a legislação francesa é aparentemente menos rigorosa que a italiana. E faz tal afirmação porque a normatização italiana exige que a autorização para a entrega vigiada seja, regra geral, escrita e motivada, devendo passar obrigatoriamente pela autoridade judicial. É dizer, ainda que a autorização não parta diretamente da autoridade judicial, esta manterá o controle da autorização concedida por demais legitimados, como as autoridades policiais, que deverão se reportar imediatamente às autoridades judiciais".

Já no caso da legislação francesa, quando a vigilância corresponder à polícia judicial somente se exige que estes agentes tenham informado, antes do início das operações, ao Procurador da República. E no caso da vigilância ser realizada pelos agentes de aduanas, estes atuarão sob o controle das autoridades judiciais.

Entretanto, Luis Fernando Rey Huidobro $^{268}$ tem posição diametralmente oposta. Entende que “a França é quem tem legislação mais rigorosa, porque sempre se faz necessária uma autorização prévia do Ministério Fiscal ou do Juiz para que os agentes policiais possam levar a cabo os atos que integram a entrega vigiada”.

Já na Itália os oficiais da polícia judiciária adstritos às unidades especializadas antidrogas, assim como as autoridades aduaneiras podem omitir ou retardar os atos de sua respectiva competência por conta própria, embora devam apresentar imediato aviso, inclusive telefônico, para a autoridade judicial (que pode dispor de forma diferente) e ao serviço central antidroga, para a necessária coordenação da ação, inclusive em âmbito internacional.

\footnotetext{
${ }^{267}$ CABADA, Gumersindo Guinarte. La Circulación o entrega vigilada de drogas. Cuadernos de política criminal. Edersa Editoriales, 1995. Madrid, p.15.

${ }^{268}$ HUIDOBRO, Luis Fernando Rey. La entrega vigilada de drogas: El artículo 263 bis de la Ley de Enjuiciamiento Criminal Revista Del Ministério Fiscal, Julio-Diciembre 1995, número 2, pág. 196.
} 


\section{CAPÍtUlO V}

\section{PRINCÍPIOS CONSTITUCIONAIS E PROCESSUAIS PENAIS ENVOLVIDOS NA UTILIZAÇÃO DA ENTREGA VIGIADA. EFICIÊNCIA E GARANTISMO}

\subsection{Considerações gerais acerca da eficiência e garantismo na persecução criminal.}

A persecução penal (notadamente aquela feita em face da criminalidade organizada, em que se faz necessário - na maioria das vezes - o emprego de meios de obtenção de provas) deve ser pautada por sua eficiência para atingir os fins almejados, sem se descurar da devida proteção aos direitos fundamentais ${ }^{269}$.

Para Antonio Scarance Fernandes" ${ }^{270}$ : "O direito ao procedimento processual penal consiste no direito a um sistema de princípios e regras que, para alcançar um resultado justo, faça atuar as normas do direito repressivo, necessárias para a concretização do direito fundamental à segurança, e assevere ao acusado todos os mecanismos essenciais para a defesa de sua liberdade ${ }^{271}$. De maneira resumida, um sistema que assegure eficiência ${ }^{272}$ com garantismo ${ }^{273}$ dos valores fundamentais do processo penal moderno"

\footnotetext{
${ }^{269}$ Não é por acaso que o tema da eficiência e garantismo vem sendo a linha de pesquisa e objeto de estudo e discussão no departamento de direito processual da Universidade de São Paulo por diversos anos, sem o alcance de uma conclusão hermética a seu respeito, face à complexidade do tema.

${ }^{270}$ FERNANDES, Antonio Scarance. Teoria Geral do Procedimento e o Procedimento no Processo Penal. São Paulo: Editora Revista dos Tribunais, 2005, p. 40

${ }^{271}$ Ada Pellegrini Grinover ao escrever sobre os procedimentos sumários (Procedimentos sumários em matéria penal. In: O processo em evolução. Rio de Janeiro: Forense, 1996, p. 228), acentuou que não vê "incompatibilidade entre essas duas tendências (garantismo e eficiência)", que destacou "como sendo os valores fundamentais do novo processo penal latino-americano" (Lineamentos gerais do novo processo penal na América Latina, Revista de Processo, São Paulo, v. 15, n. 58, p. 134, 1990). O garantismo é visto "tanto no prisma subjetivo dos direitos públicos das partes, e sobretudo da defesa, como no enfoque objetivo de tutela do justo processo e do correto exercício da função jurisdicional". A eficiência, para a autora, "se desdobra na efetividade do processo penal e na eficácia dos direitos fundamentais". De maneira semelhante, Ennio Amodio (Processo penale, diritto europeo e common law: dal rito inquisitório al giusto processo. Milão: Giuffrè, 2003, Capítulo II) afirma que os valores emergentes do direito penal europeu se congregam em uma síntese entre garantismo e defesa social. Refere a existência, na Itália e na Alemanha, de uma fase de expansão e revigoramento das garantias do imputado, seguida de outra voltada às exigências da defesa social, havendo, atualmente, a busca de uma síntese entre as preocupações garantistas e de defesa social.
} 
${ }^{272}$ Para Jean Pradel (Procédure pénale. 10. Ed. Paris: Cujas, 2000, p. 300), o princípio da eficiência é um protetor da sociedade e contém dois princípios: o da busca da verdade e o da celeridade. Em outras palavras, para o autor, o sistema criminal é eficiente quando permite a apuração dos fatos criminosos de maneira célere. Na Exposição de Motivos do Código de Processo Penal de Portugal, item 8, em referência ao objetivo da reforma tendente a alcançar "uma maior celeridade e eficiência na administração da justiça penal", foi acentuado que a "procura da celeridade e eficiência" não deve obedecer a "uma lógica puramente economicista de produtividade pela produtividade. A rentabilização da realização da justiça é apenas desejada em nome do significado direto da eficiência para a concretização dos fins do processo penal: realização da justiça, tutela de bens jurídicos, estabilização das normas, paz jurídica dos cidadãos". No texto, o vocábulo eficiência é usado de forma ampla, sendo afastada, contudo, a ideia de eficiência medida pelo número de condenações. Será eficiente o procedimento que, em tempo razoável, permitir atingir-se um resultado justo, seja possibilitando aos órgãos da persecução penal agir para fazer atuar o direito punitivo, seja assegurando ao acusado as garantias do processo legal. Para Jean Pradel, o princípio da eficiência compreende os princípios da busca da verdade e da celeridade. Contudo, na Exposição de Motivos do Código de Portugal, constou que o objetivo da reforma era o de obter maior celeridade e eficiência na administração da justiça penal; assim, a eficiência não abrangeria a celeridade. Por outro lado, para Ada Pellegrini Grinover, a eficiência se desdobra na efetividade do processo penal e na eficácia dos direitos fundamentais. Em outras palavras, a eficiência seria um conceito mais amplo e abrangeria os de eficácia e efetividade. Fernando Fernandes alude à possibilidade de "conciliar ao mesmo tempo as necessidades de garantia do cidadão com as não menos necessárias funcionalidade e eficiência do Sistema Punitivo total", inserindo o exame da eficiência no estudo mais amplo da política criminal (FERNANDES, Fernando. O processo penal como instrumento de política criminal. Coimbra: Almedina, 2001, p. 829). Para Jacinto Coutinho, não se pode tratar como sinônimas a efetividade e a eficiência. Na efetividade, há uma análise dos fins, enquanto na eficiência, dos meios (COUTINHO, Jacinto Nelson de Miranda. Efetividade do processo penal e golpe de cena: um problema às reformas processuais. In: WUNDERLICH, Alexandre. Escritos de direito e processo penal em homenagem ao professor Paulo Cláudio Tovo. Rio de Janeiro: Lumen Juris, 2002, p. 143 e ss). Aury Lopes Júnior salienta que, ao se discutir a justiça negociada, estabelece-se o conflito garantismo versus utilitarismo, ligando a ideia de utilitarismo à de eficiência (Justiça negociada: utilitarismo processual e eficiência antigarantista. In: CARVALHO, Salo de; WUNDERLICH, Alexandre (Org.). Diálogos sobre a justiça dialogal..., p. 113 e ss). Jaques de Camargo Penteado, em sua tese $O$ duplo grau de jurisdição no processo penal: garantismo e efetividade, salientou que, em vez de eficiência, melhor seria usar "efetividade", assim justificando a sua posição: "Opta-se pelo emprego do termo 'efetividade' em vez de eficiência, pois esta dá a ideia de 'ação, força, virtude de produzir um efeito', enquanto aquela indica a manifestação de 'efeito real; positivo' (Aurélio Buarque de Holanda Ferreira, Novo Aurélio século XXI: o dicionário da língua portuguesa, p. 720), o que se coaduna melhor com a nossa concepção de que se objetiva uma ordem estável, justa e segura, a partir da concreção do comando legal." (PENTEADO, Jacques de Camargo. Duplo grau de jurisdição no processo penal: garantismo e efetividade. São Paulo: RT, 2006, p. 19).

${ }^{273} \mathrm{O}$ uso do vocábulo garantismo, no direito penal e no direito processual penal, é apresentado com várias acepções. Luigi Ferrajoli, que se dedicou ao estudo do garantismo penal, na obra Diritto e ragione: teoria do garantismo penale. 4. ed. Roma/Bari: Laterza, 1997, refere a existência de três acepções do vocábulo: modelo normativo de direito; teoria jurídica de validez e da efetividade; filosofia política. Para Alexandre Wunderlich (Sociedade de consumo e globalização: abordando a teoria garantista na barbárie. (Re)afirmação dos direitos humanos. In: CARVALHO, Salo de; Wunderlich, Alexandre (Org.). Diálogos sobre a justiça dialogal: teses e antíteses sobre os processos de informalização e privatização da justiça penal. Rio de Janeiro: Lumen Juris, 2002), "o modelo jurídico estruturado no pensamento de Luigi Ferrajoli" pode ser explicitado, diante dessas três acepções, da seguinte maneira: "(I) um garantismo como Estado de Direito; níveis de normas e níveis de deslegitimação; (II) um garantismo como teoria do direito e crítica do direito e, ainda (III) o garantismo como filosofia do direito e como filosofia política". Adota-se, no trabalho, a ideia de que o garantismo no processo penal representa a efetivação do devido processo legal, nos prismas subjetivo e objetivo: como garantias das partes, essencialmente do acusado, e como garantias do justo processo. Salienta Antonio Magalhães Gomes Filho (A motivação das decisões penais. São Paulo: RT, 2001, p. 26-30) a dupla dimensão "garantista inerente ao processo", uma de ordem pública, "como garantia do correto exercício do poder", outra de perfil subjetivo, "como garantia dos direitos individuais". 
Antonio Scarance Fernandes ${ }^{274}$, observando que o processo penal reflete, em cada época e em cada local, as vicissitudes das ideologias e dos pensamentos do sistema político e tendo o autor ciência de que, ao longo da evolução histórica do processo penal, o que se alcançou não foi a criação de um procedimento ideal (para assegurar o desejável equilíbrio entre a segurança e a liberdade), mas sim a fixação de algumas regras e princípios, os quais, em seu conjunto, constituem diretrizes fundamentais para a formação dos procedimentos, conclui, com mencionadas premissas, que: "Diante desse quadro, o direito ao procedimento processual penal é, em síntese, direito a um sistema de regras e princípios que permita a atuação eficaz dos órgãos encarregados da persecução penal e, ao mesmo tempo, assegure a plena efetivação das garantias do devido processo penal”.

Portanto, imprescindível haver uma conciliação entre a eficiência ${ }^{275}$ e o garantismo. Seria um equívoco pensar em antagonismo entre eficiência e garantismo ${ }^{276}$, já que

${ }^{274}$ FERNANDES, Antonio Scarance. Reflexões sobre as noções de eficiência e de garantismo no processo penal. In: Sigilo no Processo Penal. Eficiência e Garantismo. Coord. Antonio Scarance Fernandes, José Raul Gavião de Almeida e Maurício Zanoide de Moraes. Ed. RT. 2008, p. 13.

${ }^{275}$ No estudo da eficiência e do garantismo faz-se de extrema importância a diferenciação entre os termos eficiência, eficácia e efetividade. Antonio Scarance Fernandes, nesse tema, observa que: "As origens dos vocábulos eficiência, eficácia e efetividade e as suas definições por dicionaristas (Caldas Aulete, Aurélio) mostram que eficiência é a ação, força, virtude de produzir um efeito; a eficácia é a qualidade ou propriedade de produzir o efeito desejado, de dar um bom resultado; e efetividade é a qualidade daquilo que se manifesta por um efeito real, positivo, seguro, firme, que mereça confiança. Com base nessas ideias, os autores extraem as primeiras noções dos vocábulos examinados. Onofre Alves Batista Júnior conclui: "Já aqui podemos observar que a ideia de eficiência privilegia a virtude de produzir um resultado, um efeito; tem a ver com a ação, enquanto a de eficácia pede que este resultado seja bom, seja o desejado, isto é, centra-se mais na própria qualidade do resultado." (BATISTA JÚNIOR, Onofre Alves. Princípio constitucional da eficiência administrativa. Belo Horizonte: Mandamentos, 2004, p. 111). Por outro lado, Valter Foleto Santin acentua: "Desses conceitos, podemos entender inicialmente que eficiência é o processo (ação para produzir um efeito), eficácia é a qualidade e efetividade, o resultado verdadeiro. Para a compreensão da eficiência é necessária a análise simultânea e conjunta de eficácia." (SANTIN, Valter Foleto. Controle judicial da segurança pública. São Paulo: RT, 2004, p. 141). Percebe-se que, conforme a etimologia dos vocábulos e consoante a definição a eles dada pelos dicionários, a eficiência expressa a capacidade, a força, o poder de algo que o leva a produzir um efeito. Portanto, o grau de eficiência é verificado pela maior ou menor qualidade do meio utilizado para que algo possa produzir um efeito, não pelo tipo de efeito por ele produzido. A eficácia é a qualidade do resultado produzido por algo. O grau de eficácia leva em conta o tipo de resultado atingido. Por fim, a efetividade é também a expressão do resultado produzido por algo, resultado esse que corresponde ao atingimento de determinadas finalidades. A efetividade é avaliada pelo sucesso dos resultados em cotejo com os objetivos esperados" (In: FERNANDES, Antonio Scarance. Reflexões sobre as noções de eficiência e de garantismo no processo penal. In: Sigilo no Processo Penal. Eficiência e Garantismo. Coord. Antonio Scarance Fernandes, José Raul Gavião de Almeida e Maurício Zanoide de Moraes. Ed. RT. 2008, p. 17/18).

${ }^{276}$ Neste diapasão, também afirmam que não há antítese entre eficiência e garantismo, Román Julio Frondizi e María Gabriela S. Daudet, In: Garantías y eficiência en la prueba penal. Buenos Aires: Libreria Editora Platense, 2000, p. 177/188. Para referidos autores, essa antítese existe na doutrina norte-americana entre o crime control e o due processo. Outros autores buscam tratar do equilíbrio no processo penal, como Antonio Henriques Gaspar, 
embora busquem assegurar objetivos diferentes (de um lado a persecução penal e de outro as garantias do acusado), deve existir obrigatoriamente um equilíbrio entre essas ideias no processo penal. Não se compreende eficiência sem garantismo. E garantismo sem eficiência é um vazio de objetivos na persecução criminal.

Todavia, um dos grandes desafios do processo penal consiste justamente em definir o efetivo e adequado equilíbrio entre eficiência e garantia. E, consoante exposto por Antonio Scarance Fernandes ${ }^{277}$ : "ante a impossibilidade de se definir com precisão o que configura esse efetivo equilíbrio e a extrema dificuldade em materializá-lo em textos de lei ou na aplicação concreta do direito, a sua busca representa uma meta que deve nortear o processo penal $^{278}$, fazendo com que ele, no movimento pendular da história, não se distancie do ponto médio entre a proteção à liberdade e a segurança da sociedade”.

in: Os novos desafios do processo penal no século XXI e os direitos fundamentais, um difícil equilíbrio, Revista Portuguesa de Ciências Criminais. Coimbra: Coimbra Editora, abril-junho 2005, p. 257-265, Eugênio Raúl Zaffaroni - nada personal: ensayos sobre crimen organizado y sistema de justicia, in jornadas sobre criminalidad organizada y sistema de justicia penal (2000). Universidad Nacional de Buenos Aires, Ediciones Depalma, 2001, p. 9-15.

277 FERNANDES, Antonio Scarance. Efetividade, processo penal e dignidade humana. In: Tratado LusoBrasileiro da Dignidade Humana. Ed. Quartier Latin do Brasil, 2008, p. 528.

${ }^{278}$ Há, praticamente, três correntes fundamentais sobre a finalidade do processo penal. Uma atribui ao processo penal a finalidade de assegurar a defesa do acusado. Sustenta que, historicamente, o processo penal se afirmou como instrumento necessário para evitar que se impusesse a alguém uma pena sem que pudesse defender-se. Seria, então, eficiente o processo que assegurasse ao acusado meios para o exercício de sua defesa, de modo a impedir condenações injustas. Para outra corrente, a finalidade do processo é permitir aos órgãos da persecução a apuração da verdade e a punição dos autores de infrações penais. Essa posição dá maior predominância à acusação do que à defesa do acusado, pois eficiente seria o processo que permitisse aos órgãos da persecução penal a apuração dos fatos criminosos e a condenação dos seus autores. Finalmente, terceira posição entende que a finalidade do processo penal é a obtenção de um resultado justo que se legitime pelo procedimento adequado. Deve equilibrar as posições das partes, sem dar predominância a qualquer delas, procurando compensar eventuais desigualdades naturais ou jurídicas entre elas. Eficiente, nessa ótica, é o processo justo que assegure a ambas as partes os exercícios de seus direitos e as proteja com as garantias constitucionais. A eficácia do processo penal deve ser medida em virtude do efeito que produz no tocante a sua finalidade. Para a primeira corrente, a eficácia do processo penal é avaliada pelo quanto tenha assegurado aos acusados possibilidade de resistência à acusação de modo a impedirem condenações injustas. Para a segunda, é analisada em virtude dos resultados positivos de condenações obtidas. Finalmente, para a terceira, é vista em razão de ter proporcionado possibilidades iguais à acusação e à defesa de defenderem as suas posições jurídicas, fazendo com que os julgamentos estivessem legitimados pelo uso de procedimentos adequados. Finalmente, a efetividade, em qualquer das três posições, será vista em razão dos efeitos positivos produzidos no meio social, dependendo do que se espere do processo criminal: paz social, vigência de um Estado Democrático de Direito, segurança pública, preservação da dignidade humana (FERNANDES, Antonio Scarance. Efetividade, processo penal e dignidade humana. In: Tratado LusoBrasileiro da Dignidade Humana. Ed. Quartier Latin do Brasil, 2008, p. 528). 
O processo penal ${ }^{279}$ somente se justifica se for veículo de realização da justiça, de asseguração do bem, da pacificação social, sendo essas as suas finalidades últimas. Ele será mais efetivo quanto mais conseguir realizar esses objetivos, os quais somente se concretizam se ele conseguir conjugar de forma equilibrada os interesses do Estado na perseguição de autores de crimes e dos acusados na defesa de sua liberdade ${ }^{280}$.

\section{Exatamente nesse contexto se insere a entrega vigiada. Técnica} investigativa aventada principalmente nos acordos internacionais com o claro objetivo de, por meio de cooperação entre países, estancar ou ao menos reduzir a criminalidade organizada. Mecanismo que visa imprimir eficiência na persecução da criminalidade grave, porquanto

\footnotetext{
${ }^{279}$ Figueiredo Dias aponta a importância da projeção da visão de Estado sobre o processo penal, dependente do modo como as orientações políticas típicas, historicamente afirmadas, influíram na estrutura e caracterização do processo penal: a) Numa concepção autoritária do Estado: o processo penal é então dominado, exclusivamente, pelo interesse do Estado, que não concede ao interesse das pessoas nenhuma consideração autônoma e, ligado a uma liberdade inteiramente discricionária do julgador (embora exercida sempre em favor do poder oficial), constitui o único vetor processualmente relevante. $\mathrm{O}$ arguido, por seu turno, é visto não como sujeito co-atuante no processo, mas como mero objeto de inquisição, como algo que é afeito ao processo, mas que dele não participa ativamente; b) No Estado liberal: no centro da consideração está agora o indivíduo autônomo, dotado com os seus direitos naturais originários e inalienáveis. Do que se trata no processo penal é de uma oposição de interesse (portanto, de uma lide, disputa ou controvérsia) entre o Estado que quer punir os crimes e o indivíduo que quer afastar de si quaisquer medidas privativas ou restritivas de sua liberdade. Por seu lado, a lide, para que seja "fair", supõe a utilização de armas e a disponibilidade, pelos contendores, de meios tanto quanto possíveis iguais; por isso o indivíduo não pode ser abandonado ao poder do Estado; antes tem de surgir como verdadeiro sujeito do processo, armado com o seu direito de defesa e com as suas garantias individuais; c) No Estado de direito social: a relação comunidade pessoa individual não é aqui nem a do absolutismo nem a do liberalismo; onde no processo penal desempenhar-se-á, antes de tudo, uma função comunitária, será ele próprio uma parte da ordenação comunitária. No processo penal se trata primariamente de um assunto da comunidade jurídica, em nome e no interesse do qual se tem de esclarecer, perseguir e punir o crime e o criminoso. Disso tudo se extrai que o processo não é apenas um instrumento técnico, refletindo em si valores políticos e ideológicos de uma nação. Espelha, em determinado momento histórico, as diretrizes básicas do sistema político do país.

${ }^{280}$ Antonio Scarance Fernandes utiliza a expressão paradigmas procedimentais para representar algumas diretrizes extraídas de princípios constitucionais e que devem ser levadas em conta pelo legislador na criação de procedimentos processuais penais que buscam o equilíbrio entre a eficiência e o garantismo. Para o autor, "com base nos princípios da imparcialidade, do princípio acusatório, do princípio da ampla defesa e do princípio do contraditório, pode-se, em linhas gerais, enunciar as seguintes diretrizes paradigmáticas para a estruturação de um procedimento processual penal justo, em primeiro grau de jurisdição, eficiente e afinado com as garantias do devido processo penal: a) o ato inicial do procedimento deve consubstanciar acusação oferecida por sujeito distinto do juiz, incumbindo-lhe delimitar o fato que constitui o objeto do processo e do julgamento; b) os atos do procedimento devem ser desenvolvidos de modo a proporcionar a atuação imparcial do juiz e a participação contraditória e igualitária das partes; na ordem procedimental, devem ser proporcionados à defesa meios eficazes para reagir à acusação formulada e aos atos praticados pelos órgãos acusatórios; c) durante o procedimento, devem ser reservadas fases especiais para que a acusação e a defesa possam provas as suas alegações; o julgamento só pode ser proferido após a produção de prova pelas partes e depois que essas tenham se manifestado a respeito da prova produzida" (FERNANDES, Antonio Scarance. Efetividade, processo penal e dignidade humana. In: Tratado Luso-Brasileiro da Dignidade Humana. Ed. Quartier Latin do Brasil, 2008, p. 534).
} 
capaz de enfrentar as organizações criminosas em um patamar igualitário de armas. No entanto, a preocupação de não se descurar das garantias do investigado na utilização desse meio de investigação deve ser constante.

\subsection{A inviolabilidade do sigilo das comunicações e da intimidade no emprego da entrega vigiada}

A definição de entrega vigiada exige uma efetiva atenção voltada ao conjunto normativo tutelar dos direitos fundamentais de cada um dos Estados signatários das convenções internacionais que tratam da técnica investigativa.

Em capítulo anterior restou assinalado que a entrega vigiada possui caráter excepcional, na medida em que seu emprego pode afrontar direito fundamental. Neste ponto é preciso fazer um exame detalhado acerca da utilização da entrega, para saber em quais situações pode haver ofensa aos direitos do investigado e quais direitos são ou podem ser desrespeitados.

De início, de se ressaltar que nem sempre a entrega vigiada configura ofensa aos direitos do investigado. Isto porque, no caso de simples monitoramento de remessas ilícitas, não haverá intromissão na esfera de direito legal ou constitucionalmente protegido. Assim, permitir o trânsito de remessas ilícitas, sob acompanhamento, em um primeiro momento, não ultraja nenhuma garantia.

Ademais, ainda que se saiba que a entrega vigiada, ao menos em tese, necessita de outros métodos de investigação para se chegar à informação de uma remessa ilícita para, então, poder monitorá-la, e que tais métodos possam representar diminuição da esfera de direitos do investigado, em se considerando isoladamente o monitoramento, não há que se falar em violação de princípios constitucionais ou processuais penais. 
Todavia, há corrente ${ }^{281}$ que argumenta que o simples fato de monitorar, por si só, pode ofender o direito à privacidade. No entanto, se considerada essa posição, haveria uma restrição na própria atividade investigativa ordinária, uma vez que o ato de vigiar está dentro dos procedimentos comumente usados na persecução criminal.

Mas, não é sempre que a entrega vigiada pode ser considerada uma técnica que preserve os direitos fundamentais do investigado. Isto porque, em certos casos, notadamente no emprego da entrega vigiada na modalidade denominada substituição, haverá, em regra, afronta ao direito do sigilo das comunicações ${ }^{282}$ e ao direito à intimidade ${ }^{283}$.

Neste sentido, a convenção de Viena (1988) deixa entrever sutilmente que a técnica de investigação em exame culmina em uma restrição a direitos fundamentais. De acordo com a convenção, as operações de entrega vigiada podem recair sobre substâncias que tenham sido substituídas, alterando as substâncias ilícitas objeto inicial da remessa.

\footnotetext{
${ }^{281}$ Ver,p.ex., Mendroni. Op. cit.

${ }^{282}$ Antônio Magalhães Gomes Filho, ao tratar da questão da proteção constitucional do sigilo das comunicações, ensina que: "Tradicionalmente, até porque essa era a única forma de comunicação entre as pessoas que estavam em lugares diversos, o objeto da proteção estava limitado à correspondência epistolar, mais recentemente, com os avanços da tecnologia, problemas correlatos e delicados surgiram igualmente em relação às formas modernas de comunicação, e especialmente as telegráficas, de dados informatizados e telefônicas" (GOMES FILHO, Antônio Magalhães. Direito à prova no processo penal. São Paulo: Revista dos Tribunais,1997, p. 121). A inviolabilidade das correspondências vem sendo assegurada no Brasil desde 1824, com a Constituição Política do Império do Brasil (art.179), bem como nas seguintes: de 1891, 1934, 1937, 1946, e a de 1967, com a Emenda no 1 de 1969. A Carta de 1937 (art. 122, inc. VI) foi a única que previu, expressamente, exceções à inviolabilidade, na forma da lei. Sem romper com a ideia anterior, o constituinte de 1988 manteve a proteção ao sigilo das correspondências, dentro do título dos direitos e garantias fundamentais, inserindo-o no inciso XII, do artigo $5^{\circ}$, da CF/88, o qual menciona ser "inviolável o sigilo da correspondência e das comunicações telegráficas, de dados e das comunicações telefônicas, salvo no último caso, por ordem judicial, nas hipóteses e na forma que a lei estabelecer para fins de investigação criminal ou instrução processual penal".

${ }^{283} \mathrm{O}$ direito constitucional à inviolabilidade da intimidade e da vida privada está previsto no artigo $5^{\circ}$, inciso X, da Carta Magna de 1988. O que significa dizer que o Estado, regra geral, não pode vasculhar a esfera íntima do cidadão, sem justo motivo. Para Tércio Ferraz há uma diferença de grau entre intimidade e vida privada: "A intimidade é o âmbito do exclusivo que alguém reserva para si, sem nenhuma repercussão social, nem mesmo ao alcance de sua vida privada que, por mais isolada que seja, é sempre um viver entre os outros (na família, no trabalho, no lazer em comum). Não há um conceito absoluto de intimidade. Mas é possível exemplificá-lo: o diário íntimo, o segredo sob juramento, as próprias conviç̧ões, as situações indevassáveis de pudor pessoal, o segredo íntimo cuja mínima publicidade constrange. Já a vida privada envolve a proteção de formas exclusivas de convivência. Trata-se de situações em que a comunicação é inevitável (em termos de relação de alguém com alguém que, entre si, trocam mensagens), das quais, em princípio, são excluídos terceiros" (FERRAZ, Tércio. Sigilo de dados: o direito à privacidade e os limites à função fiscalizadora do Estado, Revista dos Tribunais Cadernos de Direito Tributário e Finanças Públicas, ano 1, outubro/dezembro de 1992, p. 141-154).
} 
Evidentemente falar em substituição implica admitir a abertura do envio e, notadamente, determinadas remessas (em geral da correspondência postal) estão sob a garantia constitucional do sigilo das comunicações ${ }^{284}$.

\section{Por meio da entrega vigiada é possível observar condutas e} comportamentos reais, para comprovação da participação dos sujeitos na atividade delituosa. Passa a ser, dessa forma, uma alternativa à possibilidade legal de detenção e abertura da correspondência, uma vez que as remessas podem ser enviadas por este canal ${ }^{285}$.

De maneira que, através de correspondência é possível movimentar mercadorias (substâncias) ilícitas. A questão torna-se delicada, uma vez que o segredo das comunicações $^{286}$ e, por sua vez, da intimidade, como corolários de direitos fundamentais estão constitucionalmente protegidos.

${ }^{284} \mathrm{O}$ direito fundamental da inviolabilidade das comunicações postais encontra seu reconhecimento internacional no artigo 10 da carta dos direitos humanos, no artigo 8 do convênio europeu dos direitos humanos. $\mathrm{O}$ direito fundamental do segredo das comunicações consagra de modo implícito a proibição da interceptação ou do conhecimento antijurídico das comunicações.

${ }^{285}$ A questão das remessas pelos Correios vem tratada, especificamente, pela Lei 6.538/1978, que dispõe sobre os serviços postais, pelo Decreto 1.789/1996, que dispõe sobre o Intercâmbio de Remessas Postais Internacionais, disciplina seu controle aduaneiro e dá outras providências e pela Instrução Normativa RFB ${ }^{\circ} 1.073 / 2010$, que dispõe sobre o controle aduaneiro informatizado da movimentação e Despacho Aduaneiro de Importação e de Exportação de Remessas Expressas. Alguns pontos dessas legislações merecem destaque. Por primeiro de se observar que a aviação civil internacional e a legislação postal proíbem o transporte de certas substâncias. Os correios não transportam nenhuma substância classificada como perigosa pela IATA, cuja lista contém as seguintes proibições: 1. Explosivos; 2. Gases comprimidos, liquefeitos ou dissolvidos sob pressão; 3. Líquidos inflamáveis; 4. Sólidos inflamáveis; 5. Substâncias oxidantes e peróxidos orgânicos; 6. Tóxicos (venenosos) e substâncias infecciosas, outras substâncias médicas; 7. Material radioativo; 8. Corrosivos; 9. Produtos diversos perigosos; 10. Outras proibições ou restrições. Em complementação à esta última classificação, não será aceita a postagem de qualquer outra substância explosiva, radioativa, deteriorável, fétida, nauseante, corrosiva, nociva ou facilmente inflamável, cujo manuseio ou transporte constitua perigo ou possa causar danos a agentes postais, equipamentos ou outros objetos. Ademais, estão sujeitos à proibição ou restrição os seguintes itens: Animal Morto, ossos e cinzas animais; Armas e Munição; Artigos Indecentes ou Obscenos; Cigarros e outros produtos derivados do tabaco; Criaturas Vivas; Dinheiro em Circulação; Objetos Aceitos com Restrição; Objeto cujo Conteúdo Atente contra a Segurança Nacional; Objetos falsificados ou pirateados; Drogas Proibidas por Lei Nenhuma droga proibida por lei pode ser transportada pelos serviços dos correios. Aquelas que forem descobertas em trânsito serão retidas e entregues às autoridades alfandegárias ou policiais, que poderão tomar medidas legais contra ou remetente e/ou destinatário. Exemplo: narcóticos, substâncias psicotrópicas, LSD, morfina; cocaína, resina de haxixe, ópio etc. Remessas legalmente autorizadas, contendo entorpecentes e substâncias psicotrópicas, devem portar obrigatoriamente o endereço do remetente para o caso de não-entrega, de maneira que elas possam ser devolvidas sem demora.

${ }^{286}$ Dentro da proteção do artigo 8 da Corte Europeia de Direitos Humanos, além da proteção do direito ao respeito pela vida privada e familiar, também se encontra a proteção da correspondência. $O$ texto expressa que- 1 . Qualquer pessoa tem direito ao respeito da sua vida privada e familiar, do seu domić́lio e da sua correspondência. 2. Não pode haver ingerência da autoridade pública no exercício deste direito senão quando esta 
As operações de entrega vigiada partem de certas suspeitas. O passo seguinte consiste na constatação da suspeita, para ser convertida em evidência (que culminará na prova). Enquanto se acompanha a remessa, não há afronta aos direitos do investigado. Todavia, uma vez interceptada essa remessa, violado o seu conteúdo para substituição do mesmo por outro produto, provavelmente ocorrerá afronta a direito fundamental.

A substituição é mera possibilidade que poderá ser utilizada, uma vez sopesado os riscos de extravio das substâncias remetidas. No entanto, a entrega vigiada na modalidade substituição vai além da mera operação de vigilância, de tão somente se permitir o trânsito de remessas ilícitas sob monitoramento, pois pode se revelar uma afronta a direito fundamental do sigilo das comunicações.

Agora, efetivamente nem todas as formas de envio tradicionalmente utilizadas pelo crime organizado encontram-se acobertadas pela garantia constitucional da inviolabilidade das comunicações, em especial as postais ${ }^{287}$, pois nem todos os envios constituem instrumentos válidos de verdadeiros processos de comunicação amparados pelo direito fundamental.

ingerência estiver prevista na lei e constituir uma providência que, numa sociedade democrática, seja necessária para a segurança nacional, para a segurança pública, para o bem-estar econômico do país, a defesa da ordem e a prevenção das infrações penais, a proteção da saúde ou da moral, ou a proteção dos direitos e liberdades de terceiros.. Há uma série de casos em que é analisado o âmbito de proteção da correspondência, destacando-se os seguintes casos: a) abrange cartas - Letters (Silver and Others v. the United Kingdom, julgamento em 25 Março 1983, Series A no. 61, p. 32, § 84), including packages seized by customs officials ( $X$ v. the United Kingdom, no. 7308/75, Commission decision of 12 Outubro 1978, Decisions and Reports (DR); 16, p. 32); b) abrange conversas telefônicas - - Telephone conversations (Klass and Others v. Germany, julgamento em 6 Setembro 1978, Series A no. 28, p. 21, § 41; Malone v. the United Kingdom, julgamento em 2 August 1984, Series A no. 82, pp. 30-31, § 64; Margareta and Roger Andersson v. Sweden, julgamento em 25 Fevereiro 1992, Series A no. 226 A, p. 25, § 72) e gravações telefônicas (P.G. and J.H. v. the United Kingdom, no. 44787/98, § 42, ECHR 2001 IX), mesmo que o objetivo seja a interceptação de terceira pessoa (Kruslin v. France, julgamento em 24 Abril 1990, Series A no. 176 A, p. 20, § 26); c) abrange mensagens de pager - (Taylor-Sabori v. the United Kingdom, no. 47114/99, 22 Outubro 2002); d) abrange formas antigas de comunicação, como telex (Christie v. the United Kingdom v. the United Kingdom, no. 21482/93, Commission decision of 27 June 1994); e) abrange comunicações privadas por rádio (X. et Y. v. Belgium, no. 8962/80, Commission decision of 13 Maio 1982, Decisions and Reports (DR) 28, p. 112); f) o conteúdo da correspondência é irrelevante para o reconhecimento da violação - (A. v. France, julgamento em 23 Novembro 1993, Series A no. 277 B, p. 49, §§ 35 e 37).

${ }^{287}$ No Brasil, a empresa dos Correios possui um setor chamado de Gerência de Inspeção, por onde seguem encomendas suspeitas. Nesse setor, os pacotes são submetidos ao "Espectrômetro de Massa", para que seja identificada a existência de substâncias ilícitas. 
Isto porque, existe uma série de remessas que não está sob o manto da proteção constitucional do segredo das comunicações. Os envios de mercadorias pelos serviços ordinários de transportes não são amparados pela garantia do segredo das comunicações. Também as malas, bolsas de viagens, mochilas, 'nécessaires' e equipamentos de viagens em geral podem ser submetidos ao controle policial, nas suas funções de prevenção e averiguação dos delitos nos meios de transportes (trens, automóveis, aviões), sem ser exigido autorização judicial. Assim, como ocorre com os pacotes postais ${ }^{288}$. Todos esses podem ser fiscalizados.

\footnotetext{
${ }^{288}$ Existe questão controversa sobre a proteção da inviolabilidade das comunicações recaídas em pacotes postais. Parte da doutrina faz uma interpretação literal do termo correspondência equivalente a uma comunicação por escrito de uma pessoa com outra. E, nesse sentido, a remessa de pacotes estaria fora da definição e, por consequência, fora da proteção da inviolabilidade das comunicações. Outra parte, de forma diversa, defende a equiparação de pacotes postais com correspondência. Sobre essa questão merece transcrição parte da obra de Marta Gómez de Liaño Fonseca-Herrero, que trata especificamente dos envios que estariam ou não protegidos pela garantia constitucional da inviolabilidade: "La mayor parte de las operaciones de entrega vigilada recaen sobre paquetes postales. Una buena muestra de ello, reside en que, la equiparación jurisprudencial, tras intensos debates y vacilaciones, de los paquetes postales a la correspondencia epistolar a los efectos de su también inclusión en la garantía constitucional del art. 18.3. CE, tuvo lugar en el ámbito de circulaciones controladas. La STS de 10 de marzo de 1989 inauguró una línea jurisprudencial que excluía a los paquetes postales de la protección dispensada por el art. 18.3 en base a una interpretación literal del término correspondencia: en puridad, correspondencia equivale a una comunicación por escrito de una persona con otra; pero la remisión de unos paquetes, aun efectuada a través del servicio de correos, no puede transformar lo que en sí solo constituye un transporte de mercancía. A favor de la equiparación entre los paquetes postales y la correspondencia fueron esgrimidas razones de muy diferente tipo, que pueden sintetizarse en las siguientes: a) en la medida en que el art. $18.3 \mathrm{CE}$, los art. 579 y ss LECrim y, la normativa administrativa internacional e interna sobre la correspondencia no describen de forma expresa el contenido de las comunicaciones garantizadas, no deben excluirse los paquetes postales de la protección constitucional;; b) a raíz etimológica de la palabra, deriva de la francesa 'paquet' alusiva a 'un conjunto de cartas o papeles que forman mazo, o contenidas en un mismo sobre o cubiertas'; c) los art. 9 y 30 del Decreto 1653/1964, de 14 de mayo, de reglamentación del Servicio Público de Correos, hoy derogado por Real Decreto 1829/1999, que aprueba el Reglamento regulador de la prestación de los servicios postales, pero vigente en el momento de la equiparación, después de clasificar los diferentes objetos, susceptibles de ser transportados a través de dicho servicio, de un manera general, sin excluir desde luego a los paquetes postales, autoriza exclusivamente a la autoridad judicial la detención o interceptación de la correspondencia, y d) teniendo en cuenta que el fundamento de la protección constitucional del secreto de las comunicaciones reside en la necesidad de garantizar el respeto del ámbito privado, os paquetes postales solo deberían quedar excluidos de protección, en tanto en cuanto, pudiera aseverase, sin riesgo a equivocación, que tales paquetes únicamente pueden contener mercancías. Pero tal circunstancia no resulta posible, pues cabe remitir por correo en tal clase de envíos, elementos con datos relativos a la intimidad personal. Una parte de nuestra doctrina ha manifestado su absoluta disconformidad por la inclusión de los paquetes postales dentro del ámbito del art. $18.3 \mathrm{CE}$, ante lo que consideran una deformación de la protección constitucional del secreto de la comunicaciones y califican como ejercicio de voluntarismo judicial, desconocedor de la normativa postal" (FONSECA-HERRERO, Marta Gómez de Liaño. Criminalidad Organizada y medios extraordinarios de investigación. Editorial Colex, Madrid: 2004, p. 290).
} 
E não poderia ser diferente. Se de um lado existe a proteção ao sigilo das comunicações, esta não pode se prestar para a perpetração de ilícitos ${ }^{289}$. O crime organizado não pode se valer da proteção dispensada aos direitos fundamentais, notadamente ao segredo das comunicações e da intimidade, para conseguir mover livremente remessas ilícitas, por meio de correspondências ${ }^{290}$, dentro do território de um Estado e enviar gêneros proibidos de um país a outro.

Em razão do poder de fiscalização autoriza-se, em certos casos, a checagem e abertura $^{291}$ dos pacotes e envios de remessas. Porém, a substituição não está legalmente autorizada. A própria abertura física do pacote sem substituição, mesmo que para verificação de seu conteúdo, ainda que haja suspeita da sua ilicitude, se fora dos casos permitidos em lei, representará afronta a direito fundamental.

Ademais, não obstante a circunstância de que uma determinada remessa não entre na garantia constitucional do segredo das comunicações, isso não significa que não

\footnotetext{
${ }^{289}$ Para Nucci: “A inviolabilidade possui o sentido de proteção contra os abusos indevidos do Estado e não criar um escudo para dignificar o delito e seus praticantes. Daí por que a inviolabilidade de correspondência cederia espaço ao interesse maior, que é a garantia à segurança pública" (NUCCI, Guilherme de Souza. Código de Processo Penal Comentado. 4 ed. rev. atual. e ampl.- São Paulo: Revista dos Tribunais, 2005).

${ }^{290}$ De se frisar que as organizações se valem, na hora de traficar, das remessas por correio pela possibilidade de apresentar dados mínimos de identificação. Os destinatários e os remetentes destes envios aparecem, em regra, de três maneiras: a) utilização de nomes falsos (inexistentes), b) utilização de membros inferiores da organização criminosa; c) utilização de pessoas desvinculadas à organização, que em troca de alguma remuneração aceitam figurar como destinatários ou remetentes, conhecendo ou não o verdadeiro conteúdo da remessa. Em 13 de junho de 2010, preocupado com essa situação, O Ministério Público Federal no Distrito Federal (MPF/DF) entrou na Justiça contra a Empresa Brasileira de Correios e Telégrafos (ECT) para garantir que remetentes ou portadores de correspondências fossem obrigados a apresentar documento de identificação no momento da postagem. A medida tinha o objetivo de prevenir o frequente envio de drogas e de medicamentos proibidos. A ação pública distribuída perante a $6^{a}$ Vara da Justiça Federal no Distrito Federal cobrou, em decisão liminar, que a ECT fosse obrigada a registrar o número de identidade oficial do despachante, além dos dados já exigidos, como o nome e o endereço. Todas as informações deveriam ser anotadas na embalagem da correspondência e lançadas no sistema informatizado da empresa. Para os Correios, seria inviável adotar essas medidas por causa da grande quantidade de encomendas recebidas por dia. A empresa informou que possui outras medidas de segurança para identificar substâncias ou materiais irregulares nas correspondências. Além disso, como os dados escritos na embalagem podem ser falsos, a ECT alega que a identificação dos responsáveis pelo envio ficaria prejudicada. Fonte: http://www.correiobraziliense.com.br/app/noticia/brasil/2010/06/13/interna_brasil,197473/index.shtml.

${ }^{291}$ O Tribunal Supremo Espanhol, em uma consolidada jurisprudência, já concluiu que o uso de métodos técnicos, como o raio $\mathrm{X}$ e scanners não equivalem à abertura $\mathrm{e}$, por isso, a polícia se encontra facultada para sua utilização sem necessidade de autorização judicial, relacionada ao sigilo das comunicações (FONSECAHERRERO, Marta Gómez de Liaño. Op. cit. p. 296).
} 
seja digna da proteção dispensada ao direito à intimidade ${ }^{292}$, com relação ao exame de seu conteúdo, mediante a abertura física dos envios. O reconhecimento do caráter autônomo do direito ao segredo das comunicações não impede que possa existir a salvaguarda de outros direitos, liberdades ou bens constitucionalmente protegidos, tal como o direito da intimidade.

$\mathrm{Na}$ modalidade substituição da entrega vigiada, além da afronta aos princípios do sigilo das comunicações e, por conseguinte, da intimidade, surge a questão de qual deve ser o destino do elemento ilícito substituído. Levanta-se essa indagação porque o elemento não poderá ser de todo destruído ou extraviado, já que o investigado tem o direito de demonstrar a licitude da coisa substituída. Se destruído não haverá prova do que consistia o elemento.

Assim, eventual decisão de destruição deve corresponder unicamente ao juiz, não podendo a remessa ser destruída na integralidade porque necessita conservar uma parte para garantia da defesa e do contraditório (e da própria acusação).

A substituição do conteúdo da remessa, além de afrontar o sigilo das comunicações e da intimidade causa prejuízo ao direito de defesa, uma vez que há supressão da presença do interessado na diligência de abertura das correspondências ${ }^{293}$. A nulidade do procedimento quando não se observa a presença do investigado na abertura da remessa é evidente, ainda que se alegue que a entrega vigiada, face sua natureza cautelar deve permanecer em absoluto desconhecimento do interessado.

\footnotetext{
${ }^{292}$ Neste diapasão, sustenta Marta Gómez no tocante ao direito à intimidade: "La circulación y entrega vigilada, aunque únicamente busca información de carácter general referente a ilícitos penales, convella una afección del derecho a la intimidad, pues hay un acceso, aunque sin pretenderlo, a datos de carácter íntimo y/o privado de la esfera personal del investigado, y ello en tres circunstancias o situaciones innegable". (FONSECA-HERRERO, Marta Gómez de Liaño. Criminalidad Organizada y medios extraordinarios de investigación. Editorial Colex, Madrid: 2004, p. 297).

${ }^{293}$ Há algumas situações legalmente previstas que exigem a presença do interessado, no caso de abertura de carta. O Decreto ${ }^{\circ}$ 1.789, de 12 de janeiro de 1996, que dispõe sobre o Intercâmbio de Remessas Postais Internacionais, disciplina seu controle aduaneiro e dá outras providências, normatiza que: "Art. 10 - Não constitui violação de sigilo da correspondência postal a abertura de carta: I - endereçada a homônimo, no mesmo endereço; II - que apresente indícios de conter objeto sujeito a pagamento de tributos; III - que apresente indícios de conter valor não declarado, objeto ou substância de expedição, uso ou entrega proibidos; IV - que deva ser inutilizada, na forma prevista em regulamento, em virtude de impossibilidade de sua entrega e restituição. Parágrafo único - Nos casos dos incisos II e III a abertura será feita obrigatoriamente na presença do remetente ou do destinatário".
} 
Aliás, a entrega vigiada, por ser uma técnica de investigação visando à obtenção de provas e identificação das pessoas envolvidas em ações de organizações criminosas, por meio de vigilância de remessas ilícitas, somente será eficiente, na medida em que observar os direitos e garantias fundamentais dos investigados. Do contrário, a decretação da nulidade das provas obtidas, por meio da entrega vigiada, será de rigor.

\subsection{Liberdade probatória e seus limites relacionados aos meios de obtenção de prova atípicos como a entrega vigiada. Falta de regulamentação legal que dificulta a aplicação do instituto e possibilita a afronta a direitos fundamentais}

Levando em consideração que a utilização da entrega vigiada busca, especialmente, a coleta e reunião de provas para desmantelar o cerne da organização criminosa, durante a persecução criminal, imprescindível verificar a permissibilidade limítrofe da coleta de tais provas.

Conforme Magalhães: “O direito das partes à introdução, no processo, das provas $^{294}$ que entendam úteis e necessárias à demonstração dos fatos em que se assentam suas

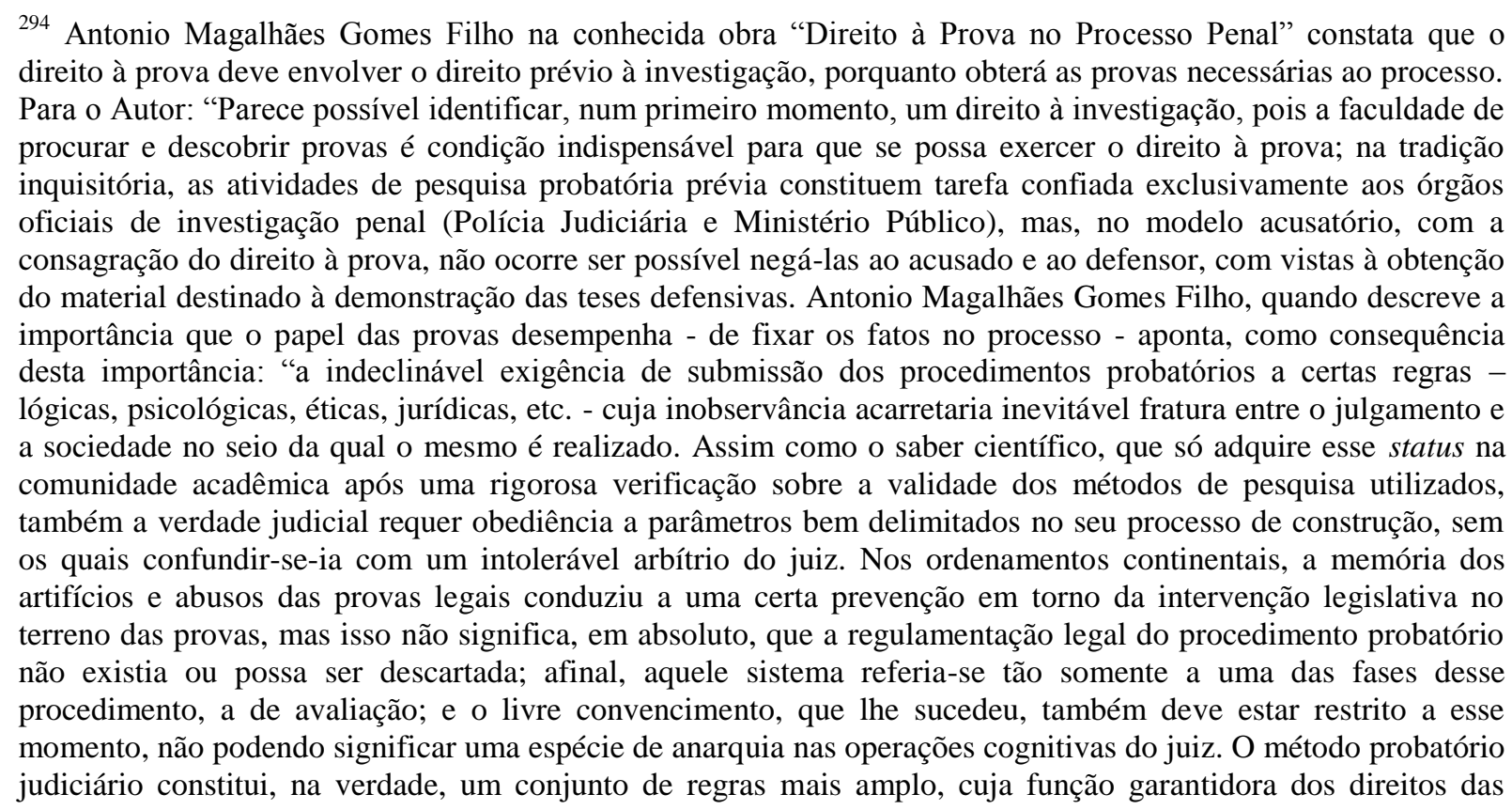


pretensões, embora de índole constitucional, não é absoluto. Ao contrário, como qualquer direito, também está sujeito a limitações ${ }^{295}$ decorrentes da tutela que o ordenamento confere a outros valores e interesses igualmente dignos de proteção ${ }^{296}$. Dessa forma, o princípio da liberdade probatória não conduz a que se reconheça liberdade plena para dispor sobre a forma de sua produção e introdução no processo".

Significa dizer que, conquanto se tenha liberdade probatória, há limites a serem observados. De início, de se frisar previamente que o exame da atipicidade da produção da prova pressupõe a precedente constatação da licitude da prova. Se uma prova é ilícita, nem se discute a sua atipicidade.

No tocante aos limites impostos à prova típica a discussão é menos fervorosa, já que prevista em lei sua possibilidade e forma de produção, ficando mais simples a constatação de seus limites.

Mostram-se mais raras as hipóteses de atipicidade completa dos meios de prova, porque normalmente têm, ao menos, previsão de seu nomen iuris no ordenamento. Nesse caso, seria atípico o meio de prova somente quanto ao seu procedimento ${ }^{297}$.

partes e da própria legitimação da jurisdição implica limitações ao objeto da prova, aos meios através dos quais os dados probatórios são introduzidos no processo, além de estabelecer os procedimentos adequados às operações relacionadas à colheita do material probatório, ou mesmo, em certas situações, o valor da prova obtida. Nessa linha, como já afirmamos antes, num processo de partes, as restrições do direito à prova de uma delas assegura, em última análise, o direito da parte contrária a uma prova corretamente obtida, produzida e valorada; dito de outro modo: ao direito à prova corresponde, como verso da mesma moeda; há, um direito à exclusão das provas que contrariem o ordenamento (GOMES FILHO, Antonio Magalhães. Op. cit. p. 93).

${ }^{295}$ Florian aponta que várias são as tentativas de criação de limites, seja para as provas disciplinadas pela lei, seja para as provas atípicas. $\mathrm{O}$ autor apresenta tentativa de sistematização dos elementos do procedimento probatório, que divide em exigências substanciais e de caráter formal. As exigências substanciais são: a) imediação da prova; b) presença e possibilidade de controvérsia entre as partes; c) cooperação das partes na aquisição da prova; d) utilização de dados científicos; e e) ausência de preclusões. Quanto às exigências de caráter formal indica: a) simplicidade e prontidão no procedimento; b) juramento; c) oralidade e escrita; d) segredo e publicidade (FLORIAN, Eugenio. De las pruebas penales, tomos I e II, $3^{\text {a }}$ reimpressão da $3^{\text {a }}$ Santa Fé de Bogotá: Editorial Temis, 1998).

${ }^{296}$ FILHO, Antonio Magalhães Gomes. Direito à Prova no processo penal. Ed. RT, São Paulo, 1997, p. 91.

297 Conforme Antonio Magalhães Gomes Filho: "a doutrina processual costuma referir-se a procedimento probatório para indicar uma sucessão de atos em que se recolhem ao processo as informações destinadas ao julgamento sobre os fatos, mas não tem sido uniforme na identificação dos diversos momentos desse procedimento". Op. Cit. p. 85. 
A controvérsia passa a surgir, com maior relevância, ao se tratar da atipicidade na obtenção da prova atípica. Verifica-se que as restrições sobre a admissibilidade dos meios de investigação atípicos são mais intensas, porque os meios de obtenção de prova são capazes de causar a interferência na esfera de direitos fundamentais. A atuação investigativa prévia ao Judiciário deve ser mais cautelosa e limitada, porque ainda não se exige a presença das partes em contraditório para resguardar os direitos e garantias do imputado.

Por isso, a admissibilidade de um meio de obtenção de prova atípica deve estar sujeita a critérios mais rígidos e deve ser marcada pela excepcionalidade ${ }^{298}$. A não taxatividade dos meios de obtenção de prova não pode significar a liberdade relativamente aos meios já disciplinados, e, por isso, as formas inominadas devem revestir-se do caráter de excepcionalidade e obedecer a parâmetros de validade mais exigentes do que os das provas tipificadas.

\footnotetext{
${ }^{298}$ No trabalho publicado sobre a XX Jornada de Málaga, pode se extrair o trecho: "É o que se encontra no artigo 234 de Costa Rica, quando ao se referir a outros meios de prova, estipula o seguinte: "A forma de sua incorporação ao procedimento se adequará ao meio de prova mais análogo dos previstos". Acentua o relator, dr. Javier Llobet Rodríguez, que a "liberdade probatória não pode significar liberdade de procedimento, pois na recepção da prova deve seguir-se o procedimento estabelecido pela lei". A forma utilizada não pode, como consta do Código de Processo Penal de La Nación, da Argentina, obstaculizar o controle de prova pelos demais intervenientes. Por outro lado, a admissibilidade de uma prova atípica deve estar sujeita a critérios mais rígidos e deve ser marcada pela excepcionalidade. É o que acentuam as relatoras portuguesas. Lembram que a não taxatividade dos meios de prova não pode significar a liberdade relativamente aos meios já disciplinados, (Germano Marques da Silva, citado pelas relatoras) e, por isso, as formas inominadas devem revestir caráter de excepcionalidade e obedecer a parâmetros de validade mais exigentes do que os das provas tipificadas. Importante é o papel do juiz no exame da admissibilidade de uma prova atípica, principalmente quando envolva restrição a direitos ou garantias, e, ainda, na determinação do rito a ser seguido. Conforme dispõe o Código de Processo Penal do Chile, deve o magistrado determinar a forma de incorporação da prova de forma a adequá-la ao meio de prova mais análogo. No Paraguai, aplica-se, em caso de prova atípica, outro procedimento por analogia, e, na falta de regras semelhantes, incumbe ao juiz estabelecer a forma adequada. Foram vários os exemplos trazidos sobre o uso de analogia para suprir a falta de regulamentação de meios de prova. Cita-se, na Argentina, o recurso à analogia para a realização do reconhecimento de fotografias, do reconhecimento de coisas, usando-se as normas sobre o reconhecimento de pessoas. Também se socorre da analogia para a atuação do intérprete com aplicação das regras sobre perícias. No Brasil, foi mencionada a efetivação do reconhecimento de coisas com base nas regras sobre o reconhecimento de pessoas, conforme remissão contida na própria lei. Lembrou-se caso em Portugal em que se admitiu a prova digital, com recurso à analogia (FERNANDES, Antonio Scarance. Prova e Sucedâneos da Prova no Processo Penal (Extraído do Relatório para as XX Jornadas Ibero americanas de Direito Processual Penal em Málaga, Espanha em 2006 e publicado na Revista Brasileira de Ciências Criminais. Editora Revista dos Tribunais, nº 66, maio/junho de 2007).
} 
Nesse caso, se o meio de investigação não for nominado, nem tiver seu procedimento estabelecido no ordenamento, sua realização muito provavelmente resultará ilegal quando tal meio se demonstre minimamente invasivo às garantias constitucionais do indivíduo ${ }^{299}$.

É de extrema importância o papel do juiz no exame de admissibilidade de um meio de obtenção de prova atípico, bem como na determinação (ou aprovação) do rito a ser seguido, notadamente por se tratar de meio de investigação envolvendo, na maioria das vezes, restrição a direito e garantias fundamentais. O vício na obtenção da fonte pode gerar ilicitude (sendo até mesmo desnecessária a análise de sua atipicidade), como sucederia, por exemplo, se uma busca domiciliar fosse realizada sem autorização do juiz nos casos em que ela é exigida.

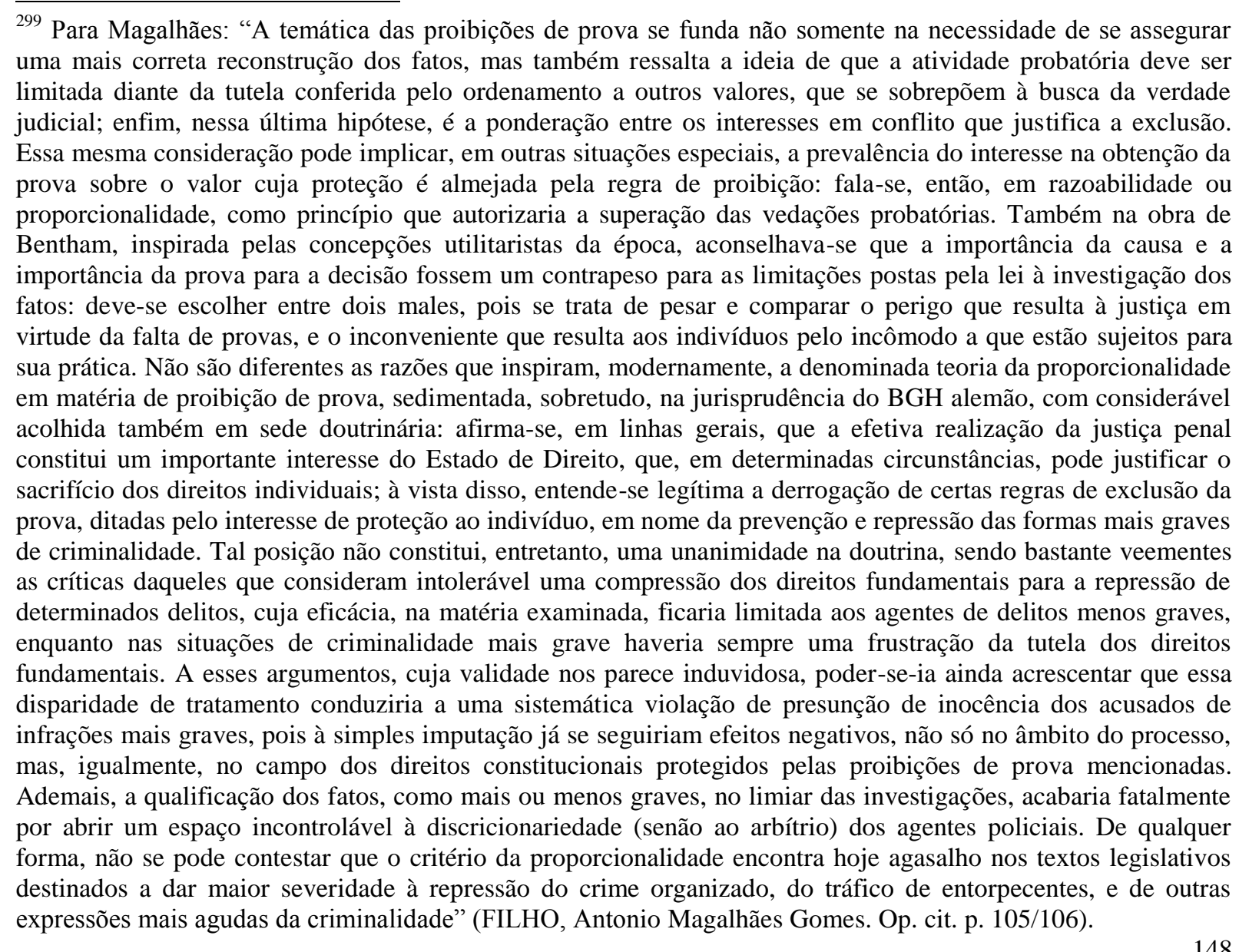


Por isso, quando da utilização da entrega vigiada, excetuados os casos de mera vigilância, torna-se indispensável o controle judicial, notadamente nos casos de afronta ao sigilo das comunicações e da intimidade para delimitar os contornos no emprego da técnica.

Nota-se que a ausência de previsão legislativa da entrega vigiada, notadamente quanto ao seu procedimento, dá margem para sua má aplicação, podendo, inclusive, afrontar direitos e garantias fundamentais, uma vez que seus agentes poderão se acobertar por detrás de comportamentos ilícitos, aproveitando, justamente, tal lacuna na legislação. A falta de uma regulamentação procedimental impede o controle do emprego da técnica no caso concreto, dificultando a utilização do instituto.

Fato é que não existe um procedimento padrão ${ }^{300}$ para a produção das provas atípicas e se discute a possibilidade de adoção de um rito de caráter genérico, que pudesse, grosso modo, englobar as regras mínimas a serem seguidas na produção dessas provas atípicas, que não têm procedimento previsto em lei ${ }^{301}$.

${ }^{300}$ Guilherme Madeira Dezem (DEZEM, Guilherme Madeira. Da prova Penal. Op. cit. p. 287) defende a possibilidade de adoção de um procedimento probatório modelo nas provas atípicas. Para o autor: "mesmo o procedimento atípico deve seguir modelos seguros para que se evite o arbítrio na forma da produção da prova de maneira a contaminar tudo o que dela derive, inclusive sua valoração". Para supracitado autor "a utilização da tipicidade processual para as provas atípicas produz importantes consequências e balizas mais seguras para a produção desses meios de prova não previstos em lei. Assim, têm-se as seguintes consequências do uso da tipicidade processual para o procedimento-modelo para as provas atípicas que não admitem qualquer forma de integração com outro meio de prova: a) a prova, como regra, deve ser praticada em juízo, sob o pálio do contraditório. Somente se admite sua produção fora dele quando a natureza do meio de prova o exigir; b) somente se admite a produção da prova atípica no inquérito policial quando houver cautelaridade a justificar tal medida ou quando a própria lei indicar tal possibilidade; c) a vontade pode atuar no meio de prova quando for elemento diretamente a ele ligado. Nesta situação, fazemos lembrar o que foi dito a respeito do elemento subjetivo volitivo e de seus vícios; d) somente se afasta a parte da produção da prova quando houver cautelaridade a justificar esta medida ou, então, quando a ciência da parte for contrária à medida. Nesta situação, não haverá, naturalmente, a incidência da regra da discussão com as partes do modelo probatório a ser seguido" (Op. Cit. p. 288).

${ }^{301}$ Observa Madeira: "Não se pode admitir que, havendo procedimento probatório específico, previsto em lei, possa a parte valer-se de meio atípico para atingir o mesmo resultado, furtando-se do estabelecido pelo legislador. Neste sentido, Antonio Scarance Fernandes afirma, com apoio em Alexy, a ideia de que há direito fundamental ao procedimento, que não pode ser afastado. Assim, a produção da prova atípica é subsidiária: somente será admitida quando não houver meio de prova típico próprio a alcançar o resultado que se pretende. Mas também pode ocorrer de a prova atípica não possuir qualquer similitude que permita a aplicação analógica de algum meio de prova típico. Nessa situação há a incidência do princípio da liberdade probatória" (DEZEM, Guilherme Madeira. Da prova Penal. Op. cit. p. 277). 
Recurso interessante foi adotado na legislação italiana em relação ao procedimento na produção da prova atípica. O artigo 189 do Código de Processo Italiano ${ }^{302}$ não cria especificamente um procedimento modelo para a produção da prova atípica, mas permite que o juiz consulte as partes e, em consenso, estabeleça um procedimento para tomada da prova atípica. Significa dizer que, a regra procedimental inexistente será instituída a partir de um modelo criado pelas próprias partes envolvidas no processo.

Para solucionar ou minorar as mazelas da utilização dos meios de prova atípicos, Antonio Scarance Fernandes ${ }^{303}$ aponta uma saída para a questão da ausência normativa, prevendo: "A obtenção ou produção de prova atípica deve seguir algum procedimento probatório, normalmente em virtude de remissão a procedimento de prova semelhante regularmente previsto ou mediante aplicação de analogia ${ }^{304}$. 302 Dispõe o artigo 189 do Código de Processo Italiano: "(Prove non disciplinate dalla legge) - 1. Quando è
richiesta una prova non disciplinata dalla legge, il giudice può assumerla se essa risulta idonea ad assicurare
I'accertamento dei fatti e non pregiudica la llibertà se essa risulta idonea ad assicurare I'accertamento dei fatti
e non pregiudica la libertà morale della persona. Il giudice provvede all'ammissione, sentite le parti sulle
modalità di assunzione della prova (Tradução livre: "1. (Prova não disciplinada pela lei) Quando se requer uma
prova não disciplinada pela lei, o juiz pode admiti-la se essa resulta idônea para assegurar a coincidência dos
fatos e não prejudicar a liberdade moral da pessoa. O juiz provê a admissão, ouvidas as partes sobre a modalidade
de tomada da prova. Em relação ao fato de que o magistrado, no sistema italiano, deverá consultar as partes
acerca da produção da prova atípica, Siracusano afirma que: (tradução livre) "Se as partes não possuem voz ativa
na modalidade de produção de provas típicas (que sabemos pontualmente prevista pela lei) devem, forçosamente,
tomá-la em relação à prova atípica (que, como é óbvio, fica aberta a cada possibilidade de operação para produzi-
la); é a mesma procura da prova atípica para fazer da parte um sujeito mais adequado a fornecer indicações úteis
buscando um modo de introduzi-la no processo: a decifração do meio implica, com efeito, a descrição de um
modelo particular de aquisição probatória. E é definitivamente esta possibilidade de participação para a escolha
do modus operandi para garantir às partes (e em especial modo à parte que não pediu a prova); que representa a
salvaguarda dos riscos de um procedimento não regulamentado pela lei" (SIRACUSANO, D.; GALATI, A;
TRANCHINA, G.; ZAPPALÀ, E. Diritto Processuale Penale. Vol. I, 3a Ed. Milano: Giuffré Editore, 2001, p.
316).

${ }^{303}$ FERNANDES, Antonio Scarance. Prova e sucedâneos da prova no processo penal. Revista Brasileira de Ciências Criminais, nº 66, maio-junho de 2007. Editora Revista dos tribunais - IBCCRIM, pág. 212.

${ }^{304}$ No Brasil temos um exemplo real da aplicação de procedimentos já existentes, por analogia, para obtenção de elementos de prova. Foi o que sucedeu com a interceptação das comunicações telefônicas, ao tempo em que não estava ainda disciplinada pela lei brasileira. Desta forma, nos casos em que se podia entender como admissível a prova resultante desse recurso técnico configurado pela interceptação das comunicações telefônicas, recorria-se ao procedimento da busca e apreensão, não de uma carta ou documento, mas dos elementos fonéticos que formam a conversa telefônica. Depois, para a introdução da prova assim obtida ao processo, aplicava-se o procedimento relativo à prova documental, uma vez que as fitas gravadas constituem documentos, em sentido amplo (GRINOVER, Ada Pellegrini. Interceptações telefônicas e gravações clandestinas no processo penal. Novas Tendências do direito processual. Rio de Janeiro: Forense Universitária, 1990. p. 63-65). Outro exemplo mencionado por Gustavo Henrique Ivahy Badaró e Antonio Magalhães Gomes Filho é o do reconhecimento de coisas. Apontam os autores que quanto ao reconhecimento de coisas há previsão de tal procedimento probatório no CPP, sem haver, contudo, uma disciplina específica. O artigo 227 limita-se a prever que, "no reconhecimento de objetos, proceder-se-á com as cautelas estabelecidas no artigo anterior, no que for aplicável". Há um 
Dessa maneira, toda produção de prova, típica ou atípica, deve pressupor a utilização de um procedimento a ser seguido ${ }^{305}$, mesmo que não previsto expressamente em lei, como é o caso dos meios de provas atípicos (que são nominados, mas não tem rito ou sequer são nominados). Isto porque, não é possível que se confunda liberdade probatória com falta de formulação de modelos a serem seguidos para a produção da prova.

Para obtenção da prova típica seu modelo está descriminado na norma. Por conseguinte, para casos de utilização de meios de obtenção de provas atípicos emprega-se o procedimento que este meio fizer menção remissivamente ou toma, por analogia, seguindose procedimento de meio similar constante no Código de Processo Penal, de legislações processuais penais extravagantes ou de Códigos e legislações processuais de natureza diversa, que guarde semelhança com o instituto a ser adotado na investigação.

Um dos grandes entraves na aplicação da entrega vigiada consiste, justamente, na falta de um procedimento legalmente detalhado, pois sem tais regras não haverá o controle de sua aplicação, podendo afrontar direito fundamental. A entrega vigiada, se não utilizada com todas as garantias que devem revestir seu emprego, causará nulidade insanável ao processo.

\subsection{Possibilidade de aplicação das regras atinentes à entrega vigiada previstas nos tratados internacionais ratificados pelo Brasil sem existência de legislação interna}

O presente tópico não objetiva uma profunda introspecção no ilimitado campo do direito internacional, notadamente no tocante aos tratados ou acordos internacionais.

aproveitamento, parcial, adaptado, do procedimento probatório do reconhecimento pessoal. (Prova e sucedâneos de prova no processo penal brasileiro. Revista Brasileira de Ciências Criminais, número 65, março- abril 2007).

${ }^{305}$ Humberto Theodoro Júnior leciona que: "Enquanto o processo é uma unidade, como relação processual em busca da prestação jurisdicional, o procedimento é a exteriorização dessa relação e, por isso, pode assumir diversas feições ou modos de ser. A essas várias formas exteriores de se movimentar o processo aplica-se a denominação de procedimentos (JÚNIOR, Humberto Theodoro. Curso de Direito Processual Civil. Vol. I, 47 edição. Editora forense, Rio de Janeiro, 2007, p. 374). Para Amaral Santos, "procedimento é, destarte, sinônimo de rito do processo, ou seja, o modo e a forma por que se movem os atos no processo" (Primeiras Linhas de Direito Processual Civil, $3^{\text {a }}$ Ed., vol. II, no 350, p.82). 
Contudo, tendo em vista que o instituto da entrega vigiada advém de previsão encartada em acordo internacional e levando em consideração que o Brasil ainda não dispõe de previsão legal de referido instituto no direito interno, surge, inexoravelmente, a questão da possibilidade de utilização, no direito interno, de instituto contido em tratados ratificados pelo Brasil, sem que haja lei interna regulando sua previsão. E, para analisar tal questão, faz-se necessário o exame de alguns aspectos do direito internacional relacionados aos tratados.

Na lição de Rezek 306 “tratado internacional ${ }^{307-308}$ é um acordo resultante da convergência das vontades de dois ou mais sujeitos de direito internacional, formalizada num texto escrito, com o objetivo de produzir efeitos jurídicos no plano internacional". Em outras palavras, o tratado é um meio pelo qual sujeitos de direito internacional principalmente os Estados nacionais e as organizações internacionais - estipulam direitos e obrigações recíprocas. Para Husek ${ }^{309}$ "tratado é o acordo formal concluído entre sujeitos de Direito Internacional Público destinado a produzir efeitos jurídicos na órbita internacional”.

Em grande parte dos manuais de direito internacional aparta-se um capítulo para reflexão sobre o fenômeno da integração (incorporação) das normas de direito

\footnotetext{
${ }^{306}$ REZEK, J.F.. Direito Internacional Público: Curso Elementar. 10ª ed. Saraiva, 2007, p.440.

${ }^{307}$ A prática internacional registra o uso livre dos diversos sinônimos da palavra "tratado" - convenção, acordo, protocolo etc. A rigor, do ponto de vista jurídico, tais nomes importam pouco e não são aplicados de maneira coerente. Existe, porém, em alguns casos, o hábito, nem sempre seguido, de se atribuir a certos tratados nomes específicos, como por exemplo: 1) convenção: costuma ser multilateral (i.e., dela participa uma número considerável de países) e dispor acerca das grandes províncias ou dos grandes temas do direito internacional, como a Convenção de Viena sobre Relações Diplomáticas (1961) ou as Convenções de Genebra (1864-1949); 2) acordo: usualmente bilateral ou plurilateral, pode ser também multilateral; é um termo genérico para tratado; e.g. Acordo de Camp David; 3) protocolo: costuma ser um tratado acessório a, ou resultante de, um tratado principal, como o Protocolo Adicional à Convenção Interamericana sobre Cartas Rogatórias (1979); 4) memorando de entendimento: às vezes (mas nem sempre) designa tratados sobre temas técnicos ou específicos, como o Memorando de Entendimento sobre Cooperação entre as Academias Diplomáticas entre Brasil e Colômbia (2005); 5) concordata: é o tratado celebrado entre um Estado e a Santa Sé, como a Concordata de Bolonha; 6) tratado: costuma dar nome a atos especialmente solenes, como o Tratado para a Constituição de um Mercado Comum entre a República Federativa do Brasil, a República Argentina, a República do Paraguai e a República Oriental do Uruguai, também conhecido como Tratado de Assunção (1991); 7) carta ou constituição: costuma designar tratados constitutivos de organizações internacionais, como a constituição da OIT ou a Carta da ONU.

${ }^{308}$ A Convenção de Viena, de 1986, regula o direito dos tratados celebrados entre Estados e organizações internacionais, e entre estas. $\mathrm{O}$ Tratado de Kadesh, um dos primeiros exemplos registrados de um tratado internacional, foi celebrado no século XIII a.C. entre Ramsés II do Egito e Hatusil III, rei dos hititas. Exemplar do Museu de Arqueologia de Istambul, Turquia (Mello, Celso D. de Albuquerque. Direito Internacional Público: Tratados e Convenções. $5^{\text {a }}$.ed. Renovar, 1997.p.1370).

${ }^{309}$ HUSEK, Carlos Roberto. Curso de Direito Internacional Público. Ed. LTR, 5 a ed., São Paulo, 2004, p. 57.
} 
internacional aos ordenamentos internos dos Estados ${ }^{310}$. Neste sentido, crucial se faz a análise de como os tratados internacionais se inserem no ordenamento jurídico brasileiro ${ }^{311}$.

${ }^{310}$ Os juristas usualmente identificam as seguintes fases para a conclusão de um tratado internacional: a) negociação: é a primeira fase do processo de conclusão de um tratado, da competência exclusiva do Poder Executivo. Ao término desta fase, existe um texto escrito que é consensual e que pode ser rubricado pelos negociadores. A rubrica não é assinatura, mas apenas autentica o texto negociado. Nesta fase inicial, as Partes procuram elaborar o texto convencional, por meio de propostas de redação. b) assinatura: a assinatura é um ato que autentica o texto do tratado mas não o torna imediatamente obrigatório para as Partes. A assinatura faz-se, via de regra, sob reserva de ratificação, i.e., é necessário um ato adicional e posterior (usualmente chamado "ratificação") que comunique a vinculação do Estado aos termos do tratado. A critério da Parte Contratante, a sua assinatura pode desde já vinculá-la juridicamente (sempre que o seu direito constitucional o permitir). A assinatura marca o início do prazo (se houver) para depósito dos instrumentos de ratificação. Assina o tratado, em nome do Estado que representa, o agente que estiver munido de plenos poderes. A competência para conceder os plenos poderes costuma ser do Poder Executivo. Há uma obrigação particular que decorre da assinatura do tratado, mesmo que ainda não tenha ocorrido a ratificação e a entrada em vigor. Trata-se da obrigação de não frustrar o objeto e finalidade de um tratado antes de sua entrada em vigor; c) procedimento interno, se cabível: a assinatura sob reserva de ratificação (a mais comum) permite o início do procedimento interno de aprovação do tratado. É a fase na qual os órgãos internos do Estado apreciam o teor do tratado e o aprovam ou o rejeitam. Em determinados Estados, o seu direito constitucional exige que o tratado seja submetido à apreciação do Poder Legislativo (Congresso, Parlamento, Senado etc.); em outros, não há este tipo de exigência e o Poder Executivo é livre para ratificar o tratado quando lhe convier; em outros Estados, ainda, a necessidade de aprovação legislativa existe para alguns tipos de tratado, e não para outros. Em geral, o Poder Executivo detém a prerrogativa de decidir quando enviar o tratado para apreciação legislativa. Ou seja, o envio ao Poder Legislativo não é automático - o Executivo pode decidir-se por não o enviar; neste caso o tratado não entra em vigor para aquele Estado. Se o direito constitucional do Estado exigir a aprovação legislativa, a rejeição do tratado pelo Legislativo inviabiliza a sua ratificação e consequente entrada em vigor para aquele Estado. Em tese, é possível que o direito constitucional de algum Estado exija que o tratado seja aprovado por um órgão interno que não o Legislativo: um partido político, ou o gabinete de Ministros, por exemplo; d) ratificação: a ratificação é o ato pelo qual uma Parte Contratante informa à(s) outra(s) que se considera doravante obrigada aos termos do tratado no plano internacional. Pode ocorrer que o tratado não entre em vigor neste momento, caso o seu texto estipule uma condição adicional para tanto (número mínimo de ratificações, para um tratado multilateral; ou um prazo após a entrega do segundo instrumento de ratificação, para um tratado bilateral). A ratificação é um ato discricionário, isto é, a Parte Contratante decide livremente sobre a sua conveniência e oportunidade. No plano interno dos Estados, costuma ser ato (também discricionário) do Poder Executivo. O Executivo, uma vez concluídos os procedimentos internos, tem a prerrogativa de decidir quando ratificar o tratado e o fará se assim o desejar. No caso dos tratados bilaterais, as Partes Contratantes trocam os respectivos instrumentos de ratificação; no caso dos tratados multilaterais, os instrumentos de ratificação são depositados junto a uma das Partes ou a uma organização internacional para tanto designada; e) promulgação e publicação: o direito constitucional de alguns Estados exige, ainda, para que o tratado seja obrigatório para os seus órgãos internos, a promulgação. Esta é o ato jurídico, de natureza interna, pelo qual o governo de um Estado atesta a existência de um tratado devidamente ratificado e ordena a sua execução no seu território. A partir de então, o tratado é obrigatório também no plano interno. Cabe ressaltar a diferença, em termos práticos, entre os efeitos da ratificação e os da promulgação. Se um Estado ratifica um tratado mas não o promulga (e o seu direito constitucional exige a promulgação), o texto convencional lhe é obrigatório no plano internacional mas não no plano interno. Neste caso, o Estado em questão pode ver-se na posição de ser cobrado nas suas obrigações convencionais pelas demais Partes Contratantes, mas acontecer de um de seus órgãos internos recusar-se a aplicá-las por falta de promulgação. Nasce, então, uma situação de responsabilidade internacional da parte do Estado faltoso. Já a publicação em jornal oficial é prérequisito para a aplicação do tratado pelos órgãos internos do Estado e é adotada por todos os países, com ligeiras diferenças de procedimento entre si; f) Registro: a Carta das Nações Unidas (1945) estabelece que todos os tratados devem ser registrados no Secretariado da ONU. Os tratados não registrados não podem ser invocados perante órgão da ONU. O registro advém do princípio que condena a diplomacia secreta (MELLO, Celso D. de Albuquerque. Direito Internacional Público: Tratados e Convenções. 5ªd. Renovar, 1997, p.1370). 
Em razão da soberania constitucional, os tratados assinados devem ser ratificados de acordo com as regras internas de cada Estado. Todavia, não há normas específicas no Direito Internacional que regulam a recepção dos tratados na ordem interna motivo pela qual a discussão é interminável - sendo cada país livre para disciplinar a entrada e vigência das normas convencionais ${ }^{312}$. Entretanto, duas são as teorias principais que norteiam esse processo de incorporação do tratado ao direito interno.

Em termos gerais, para os adeptos da escola dualista ${ }^{313}$ existe uma separação radical entre o ordenamento jurídico internacional e o nacional. As razões, como aponta Díez de Velasco ${ }^{314}$, seriam as de que "as relações que regulamentam ambos os direitos são distintas, já que o internacional é dedicado a regular as relações entre os Estados e os internos as relações entre indivíduos". Dessa maneira, a teoria dualista ${ }^{315}$ estabelece uma dissociação entre os direitos internos de cada País e o direito internacional, instituindo dois sistemas jurídicos diversos, impenetráveis. Para a teoria dualista, a incorporação dos tratados internacionais pelo ordenamento jurídico interno seria feita através de lei específica.

\footnotetext{
${ }^{311}$ Com relação a essa análise, Dallari observa que: "Esta é uma questão fundamental, pois, se proliferam as normas de direito internacional público, se o Estado, no exercício de sua soberania, contrata tais normas, supõe-se que tal contratação não seja uma espécie de estelionato internacional, mas que, pelo contrário, ela seja feita para que gere efeitos. Essa é a lógica do sistema" (DALLARI, Pedro de Abreu. Normas Internacionais de Direitos Humanos e a Jurisdição Interna. Revista Especial do Tribunal Regional Federal $3^{a}$ Região. São Paulo, 1997, p.27-28).

${ }^{312}$ REZEK, J.F.. Direito Internacional Público: Curso Elementar. 10ª.ed. Saraiva, 2007, p.79

${ }^{313}$ Triepel, o mais destacado defensor da teoria afirma "que o direito internacional público e o direito interno não são somente partes, ramos de direito distintos, mas, mais ainda sistemas jurídicos distintos. São dois círculos que estão em contato íntimo, mas, que não se sobrepõe jamais. Já que não se regem pelas mesmas relações, é impossível que haja uma 'concorrência' entre as fontes de dois sistemas jurídicos (...). Portanto, não se pode falar de uma recepção do direito internacional pelo Estado sem que o conteúdo da regra estatal corresponda exatamente ao conteúdo da regra jurídica internacional (H. Triepel. Les rapports entre Le droit interne ET Le droit international. Recueil des Cours de L'Academie de Droit International de La Haye, 1923. Vol. I, p. 81-97). Kelsen, em um de seus trabalhos, chegou a afirmar que "a construção dualista é aquela dos primitivos. Os membros de uma sociedade primitiva são incapazes de conceber uma ordem jurídica em volta deles que regule sua própria comunidade" - Kelsen foi um dos principais defensores da teoria monista - (KELSEN, Hans. Théorie Du droit international public. Recueil des Cours de L'Academie de Droit International de La Haye, 1953. Vol. III, p. 188).

${ }^{314}$ VELASCO, M. Díez de. Instituciones de derecho internacional público. $8^{\text {a }}$ Ed. Madrid: Tecnos, 1988, t.I, p. 164.
}

315 Alfred Von Verdross é o criador da expressão "dualismo” em 1914. 
Já para a teoria monista ${ }^{316}$ existe uma unidade no ordenamento jurídico (interno e internacional), visto como um todo. Não se admite uma dicotomia entre os dois ordenamentos, já que, de um lado, o Estado firma tratados no exercício de sua soberania soberania essa que só existe se reconhecida pelo direito internacional - e, de outro, o tratado obriga não só o Estado, mas os súditos desse Estado, criando-lhes direitos e obrigações. De modo que, ao firmar tratados, o Estado estaria fazendo ingressar automaticamente no seu sistema normativo as normas pelas quais se obrigou, sendo desnecessária a edição de norma interna para que os Tribunais passassem a aplicar o tratado na decisão de conflitos ${ }^{317}$.

Dentro do sistema monista há formulações diversas, na avaliação de prevalência das normas internacionais ou interna, em casos de divergências. Rezek ${ }^{318}$ cita três correntes principais dessas formulações: a) Teoria monista intrínseca: defende que o direito interno prevalece em relação ao direito internacional em caso de conflitos entre normas; b) teoria monista extrínseca: defende a prevalência das normas internacionais em relação às estruturas legislativas internas; $\mathrm{c}$ ) teoria monista moderada: defende a equiparação hierárquica entre normas internas e internacionais. A prevalência de uma ou de outra dependerá de sua origem, do tema tratado, ou do fato de ser mais recente.

O importante no presente estudo é apontar que o Brasil adota a teoria monista (moderada). Significa dizer que o tratado ingressa no ordenamento jurídico interno sem necessidade de lei no sentido formal ${ }^{319}$. Em verdade, pelo nosso sistema, é de

\footnotetext{
${ }^{316}$ A teoria monista tem como base a unificação de regras normativas, defendendo a existência de um direito único ou coincidente para todos os países. Nesse sentido haveria um ordenamento jurídico internacional, uniforme, que deveria ser imposto aos Países.

${ }^{317}$ Kelsen foi, sem dúvida, o grande teórico do monismo internacionalista, aquele que deitou raízes para a moderna compreensão do fenômeno da interação de normas partindo do referido conceito de "norma fundamental" como fonte de quaisquer normas, afirma que quer as normas internacionais, quer as internas, teriam as mesmas fontes, quais sejam, a lei e o costume. A norma fundamental é exatamente a que declara a lei e o costume como fatos geradores do direito. A supremacia deriva simplesmente do fato de o Estado estar obrigado pelo direito internacional, já que não pode invocar as disposições de seu direito interno para eximir-se do cumprimento das obrigações internacionais, ou para escapar de suas consequiências. Op. Cit. p. 144.

318 Op. cit. 89.

${ }^{319}$ Conforme decidiu o STF, na extradição 662-2, os tratados internacionais guardam paridade normativa com leis ordinárias: "Tratados e convenções internacionais - tendo-se presente o sistema jurídico existente no Brasil (RTJ 83/809) - guardam estrita relação de paridade normativa com as leis ordinárias editadas pelo Estado brasileiro. A normatividade emergente dos tratados internacionais, dentro do sistema jurídico brasileiro, permite situar esses atos de direito internacional público, no que concerne à hierarquia das fontes, no mesmo plano e no mesmo grau de eficiência em que se posicionam as leis internas do Brasil. A eventual precedência dos atos
} 
competência exclusiva do Executivo (chefe do Estado ou plenipotenciários) a celebração de tratados (art. 84, VIII, da CF/88) ${ }^{320}$. Ao Congresso é enviada cópia do texto, a qual, se aprovada, gera a publicação de um decreto legislativo (art. 49, I, da CF/88) ${ }^{321}$, cuja função é apenas a de dar ciência da aprovação do texto apreciado, das reservas eventualmente impostas, das cláusulas facultativas aceitas etc. Somente após a aprovação do texto é que o Executivo ratifica o tratado, por decreto presidencial) e, por via da promulgação, assinala o início de sua vigência e eficácia no País. Nem o decreto legislativo, nem o decreto do executivo de promulgação podem ser considerados "lei" no sentido de norma de direito interno editada segundo a forma e procedimento previstos na Constituição ${ }^{322}$.

Conclui-se, então, de acordo com essa teoria, que a simples ratificação (pela via da promulgação) do tratado é suficiente para sua imediata aplicação no âmbito interno $^{323}$, independentemente de lei, em razão do Poder Legislativo participar via decreto do processo de incorporação.

internacionais sobre as normas infraconstitucionais de direito interno brasileiro somente ocorrerá - presente o contexto de eventual situação de antinomia com o ordenamento doméstico -, não em virtude de uma inexistente primazia hierárquica, mas, sempre, em face da aplicação do critério cronológico (lex posterior derogat priori) ou, quando cabível, do critério da especialidade. Precedentes. (Relator Min. Celso de Mello, julgado em 28/11/1996, Tribunal pleno).

${ }^{320}$ Art. 84. Compete privativamente ao Presidente da República: VIII - celebrar tratados, convenções e atos internacionais, sujeitos a referendo do Congresso Nacional;

${ }^{321}$ Art. 49. É da competência exclusiva do Congresso Nacional: I - resolver definitivamente sobre tratados, acordos ou atos internacionais que acarretem encargos ou compromissos gravosos ao patrimônio nacional;

${ }^{322}$ STEINER, Sylvia Helena de Figueiredo. A convenção americana sobre direitos humanos e sua integração ao processo penal brasileiro. Editora RT: São Paulo, 2000, p. 70.

${ }^{323}$ Lembra Harada que: "Até o advento da EC n ${ }^{\circ} 45 / 04$, a posição majoritária do STF sempre foi no sentido de que os tratados internacionais são absorvidos como normas infraconstitucionais, assumindo a condição de leis ordinárias federais. Sobreveio a EC $\mathrm{n}^{\mathrm{o}} 45 / 04$ conferindo status de emenda constitucional aos tratados e convenções internacionais sobre direitos humanos que fossem aprovados, em cada Casa do Congresso Nacional, em dois turnos, por três quintos dos votos dos respectivos membros, conforme o Art. $5^{\circ}$, § $3^{\circ}$, que dispõe: "Os tratados e convenções internacionais sobre direitos humanos que forem aprovados, em cada Casa do Congresso Nacional, em dois turnos, por três quintos dos votos dos respectivos membros, serão equivalentes às emendas constitucionais". Parece-me que assim procedeu o legislador constituinte, tendo em vista que a Corte Suprema não vinha aplicando o disposto no $\S 2^{\circ}$, do art. $5^{\circ}$, da $\mathrm{CF} / 88$, exatamente porque os tratados eram aprovados, indistintamente, por decreto legislativo, e como tal, não tinham o condão de conferir status de norma constitucional. Compreende-se a preocupação da Corte no sentido de que a atribuição de status de norma constitucional conduzirá, na prática, a situações de revogação de preceitos constitucionais por meio de tratados. Há que se ponderar, contudo, que é irreversível a tendência dos Estados nacionais de incorporar em seus Estatutos Magnos os princípios e regras de direito internacional por meio de tratados que firmam voluntariamente. A Constituição continua representando a emanação da soberania do Estado Parte, mesmo porque só podem ceder e fazer concessões recíprocas os que detêm soberania. A soberania, como um dogma político intangível, não mais existe neste mundo globalizado. Os países que compõem a União Europeia, por exemplo, estruturaram o Direito Comunitário, onde as Constituições dos países-membros funcionam como legislação interna. Por derradeiro, se eventualmente o tratado firmado afrontar dispositivo constitucional inserido 
De todo o quanto exposto, outra conclusão parece evidente, qual seja, da possibilidade de aplicação da entrega vigiada no âmbito interno, mesmo na ausência de legislação interna, já que o Brasil é signatário de diversos acordos internacionais que prevêem a existência desse instituto, o que por si só, autorizaria sua utilização (de acordo com a teoria monista $^{324}$ adotada pelo país ${ }^{325}$.

Todavia, a questão não é tão simples como aparenta ser. Neste caso, a falta de legislação interna, discorrendo sobre a forma e procedimento a serem utilizados no emprego da entrega vigiada no âmbito interno do País, torna-o um meio de obtenção de provas atípico e, muitas vezes, de uso excepcional, porquanto passível de limitar direitos fundamentais.

Assim, uma reflexão deve ser feita. Um tratado ratificado pelo Brasil pode ser aplicado automaticamente no âmbito interno, independentemente de lei, quando seu conteúdo origine direitos a serem acrescentados na órbita dos destinatários. Porém, quando o tratado justamente previr o contrário, ou seja, restrição de direitos fundamentais, sua aplicação automática, sem existência de lei interna, torna-se delicada e controvertida.

no núcleo protegido por cláusulas pétreas, o Congresso Nacional não deverá aprová-lo. Se eventualmente for aprovado apesar do vício retro apontado caberá ao STF, como guardião da Constituição, declarar a sua inconstitucionalidade, sempre que for provocado" (HARADA, Kiyoshi. Tratado internacional e prisão por divida. <http://jus2.uol.com.br/doutrina/texto.asp?id=12078>. Acesso em: 03 jul. 2010). Até o advento da EC 45/2004, Carlos Weis colocava que o ingresso na órbita interna dos tratados na qualidade de normas constitucionais não poderia ser admitido: "tratam-se de sistemas absolutamente distintos que se operam através de mecanismos próprios, desde a confecção até a entrada em vigor da norma. Assim, se as emendas constitucionais extraem sua legitimidade da maioria qualificada existente para sua aprovação, no campo internacional chega-se a semelhante resultado diante do complexo processo de elaboração dos tratados. (...) Então, ainda que a ratificação somente exija maioria simples, sua incorporação ao direito interno passa necessariamente pelo crivo dos dois Poderes que representam a vontade popular" (WEIS, Carlos. Direitos Humanos contemporâneos. São Paulo: Malheiros, 1999, p. 34-35).

${ }^{324}$ Como assinala Pedro Dallari: "o tratado ingressa no direito brasileiro - e entendo que essa é uma questão pacífica hoje - com vida própria, com forma própria, por força do compromisso internacional celebrado pelo Brasil, sendo o decreto presidencial a via pela qual se dá a publicidade ao seu conteúdo e se fixa o início de sua vigência no território nacional. Prevalece, assim, a solução monista para o dilema da integração dos tratados de direito internacional público ao direito interno" (Op. Cit. 31-32).

${ }^{325}$ A doutrina é unânime em defender que o primeiro impacto, ou seja, consequência jurídica provocada pelo ingresso do tratado na Ordem Jurídica Interna seria o fato de que o conteúdo desses tratados possam ser absorvidos pela Constituição. Os tratados uma vez ratificados têm auto aplicabilidade e criam obrigações legais aos Estados membros. 
É sabido que o instituto da entrega vigiada pode ser, em certas hipóteses, um meio excepcional de obtenção de provas. Também é fato que tais meios devem estar expressamente regulados, para que sua utilização seja a menos gravosa possível. Com isso, sua previsão configura medida penal mais restritiva e o emprego automático da entrega vigiada, nos moldes esposados pelas Convenções (que não definem seu procedimento de aplicação), impedirá, muitas vezes, o devido controle a que tal medida deve submeter-se, acarretando prejuízos maiores na esfera de direito dos supostos investigados.

De se entender que a Convenção ratificada, pela teoria monista, já foi incorporada ao ordenamento jurídico interno e em tese devem ser respeitados todos os seus termos que não foram eventualmente ressalvados. Porém, na parte em que prevê restrição de direitos $^{326}$, como na previsão da técnica investigativa da entrega vigiada, na modalidade substituição, por exemplo, cabe ao Brasil, a partir da definição contida na Convenção, regulamentar sua forma de aplicação ${ }^{327}$, assim como fez a Espanha.

\footnotetext{
${ }^{326}$ Para Luiz Alberto Davi Araujo e Vidal Serrano: "o argumento de que o tratado poderia vir a restringir direitos, e aí também modificar cláusulas pétreas, não nos parece procedente, à vista do que vem disposto na própria Convenção Americana sobre a interpretação dos tratados, no sentido de que não podem ser invocados os direitos previstos na Convenção para limitar o gozo e o exercício de qualquer direito ou liberdade reconhecido pelo ordenamento interno" (Curso de direito constitucional. São Paulo: Saraiva, 1998, p. 130-132).

${ }^{327}$ Exatamente em razão do novo panorama da comunidade internacional, e das relações cada vez mais complexas interligando os Estados em todas as áreas, o quadro que se vislumbra em desenvolvimento é o da acolhida cada vez maior e mais ampla das normas de direito internacional nos ordenamentos dos Estados, especialmente em suas constituições. Brownlie lembra que "acima da natureza das obrigações decorrentes de tratados e das normas consuetudinárias, há o dever geral para os Estados para que sejam elaboradas leis nacionais em conformidade com as obrigações internacionais assumidas" (BROWNLIE, Ian. Principles of public international Law. 4. ed. Oxford: Clarendon Press, 1990. p. 35). Esse fato está a demonstrar o reconhecimento de que, nos dias atuais, nenhum Estado pode realizar seus objetivos isoladamente (STEINER, Sylvia Helena de Figueiredo. A Convenção Americana sobre direitos humanos e sua integração ao processo penal brasileiro. Ed. RT, 2000, p. 66).
} 


\section{CAPÍtULO VI \\ CRÍTICAS E SUGESTÕES NA UTILIZAÇÃO DA ENTREGA VIGIADA}

\subsection{Críticas na utilização da entrega vigiada}

O adequado emprego da entrega vigiada demanda a observância de uma série de requisitos. Do contrário, o que deveria servir para promoção da justiça, tornando eficaz a persecução criminal, pode se transmudar em um instituto perigoso e eventualmente ofensivo a direito fundamental do investigado.

Atualmente, possível detectar alguns problemas na implementação e utilização dessa nova técnica de investigação. A principal crítica refere-se à insuficiência legislativa, porque imprescindível a existência de uma normatização que possibilite o emprego do instituto, de forma a garantir os direitos fundamentais.

Outros pontos discutíveis não podem ficar à margem de exame neste capítulo, como a possibilidade do agente destacado para monitorar a remessa ilícita provocar ou cometer delitos ou, ainda, o desvirtuamento na aplicação da entrega vigiada como instituto permissivo da perpetração da criminalidade organizada.

\subsubsection{Insuficiência legislativa}

No Brasil, o instituto da entrega vigiada ainda é muito incipiente, valendo-se, basicamente, das previsões nas diversas convenções internacionais, especialmente de acordos internacionais, como a Convenção de Viena de 1988, além da Convenção Interamericana contra a fabricação e o tráfico ilícitos de armas de fogo, munições, explosivos e outros materiais correlatos - Washington de 14/11/1997; da Convenção das Nações Unidas 
contra o crime organizado transnacional (Convenção de Palermo) de 15/11/2000 e da Convenção das Nações Unidas contra a corrupção de 31/10/2003, das quais o Estado Brasileiro faz parte, para sua efetiva aplicação.

Consoante concluído em capítulo anterior inexiste previsão legislativa da entrega vigiada no ordenamento jurídico interno. Portanto, essa insuficiência legislativa aliada ao meio de investigação que a entrega vigiada representa - de caráter excepcional em algumas situações - relativamente novo e sem muitos precedentes, torna a aplicação deste método investigativo muito dificultoso, para não dizer perigoso.

$\mathrm{Na}$ verdade, sem previsão legislativa, o emprego da entrega vigiada poderá restar prejudicado, uma vez que a atipicidade deste meio investigatório para obtenção de prova possivelmente afrontará regras de direito processual ou garantias individuais. A solução do emprego de analogia ou remissão a outros institutos geralmente resulta em nulidade.

Atualmente, sem previsão normativa interna, a aplicação da entrega vigiada pode ser empregada de duas maneiras: a primeira delas, com a utilização da analogia ou remissão às regras de outro instituto.

A segunda possibilidade seria partir do princípio que é possível a aplicação direta de um instituto previsto em Convenção Internacional ratificada pelo Brasil, de forma automática no âmbito interno do Estado, sem a necessidade de regulamentação pela legislação pátria daquele instituto previsto na Convenção, utilizando-se as regras previstas no próprio tratado internacional.

Contudo, mesmo diante dessa admissão, de se frisar que tão somente a existência de alusão a um instituto com sua mera definição, sem a existência de um procedimento regularmente delimitado, tratando das hipóteses de sua utilização, isto é, quais situações e tipos de crimes poderiam ser empregados e demais regras processuais para uma 
escorreita e equilibrada aplicação, fatalmente obstaculizaria a aplicação direta do instituto, por absoluta falta de norma capaz de autorizar seu emprego, de forma segura e eficaz.

A ausência de uma legislação detalhada acerca da aplicação da entrega vigiada, notadamente quanto ao seu aspecto procedimental, representa o principal empecilho para a efetiva utilização do instituto.

Ainda neste capítulo, no intuito de contribuir com o tema estudado, serão sugestionadas as condições mínimas que deveriam estar legalmente previstas para que se torne legítimo o uso entrega vigiada.

\subsubsection{O agente (policial) vigilante provocando ou cometendo delito}

A entrega vigiada tem estrita ligação com a utilização de policiais no uso dessa técnica. Aliás, o ato de vigiar e monitorar são exercidos, notadamente, pelos agentes policiais. Na entrega vigiada não é diferente. Os policiais (ou outros possíveis agentes destacados em lei) ficam em campana, com o objetivo de desmantelar organizações e coletar o maior número de elementos possíveis de prova.

Todavia, além da mera vigilância, nada impede que a entrega vigiada seja empregada com a utilização conjunta de agentes infiltrados ${ }^{328}$, que farão concomitantemente o monitoramento, muitas vezes de dentro das organizações criminosas ou contribuirão repassando previamente as informações de possíveis itinerários para que os demais agentes coligados possam fazer o acompanhamento das remessas.

\footnotetext{
${ }^{328}$ Guilherme de Souza Nucci observa que: "havendo infiltração de agente estatal em quadrilha ou bando, organização criminosa ou outra associação delituosa, torna-se essencial, para a segurança do próprio infiltrado, que a autorização dada pelo juiz permaneça em absoluto sigilo, durante todo o período em que estiver atuando. Cremos que a expressão estritamente sigilosa deve envolver todo e qualquer funcionário, inclusive os do cartório da Vara, do Ministério Público e outros policiais da delegacia ou órgão especializado. Somente o magistrado que autorizou, o membro do Ministério Público, que fiscaliza a investigação, e a autoridade policial condutora do inquérito devem ter acesso à infiltração efetivada" (NUCCI, Guilherme de Souza. Leis Penais e Processuais Penais Comentadas. São Paulo: Editora RT, p. 204).
} 
No ato de vigiar, o agente (policial) destacado para essa tarefa, que esteja em campana, diferentemente do agente inserido na organização como agente infiltrado, está rigorosamente obstaculizado, de provocar ou cometer delitos. A técnica da entrega vigiada não abre oportunidade, nem autoriza o cometimento de delitos. Até porque o agente vigilante não corre risco de morte que autorize, excepcionalmente, o cometimento de delito, como no caso do agente infiltrado.

Justamente por isso distingue-se a entrega vigiada da técnica do agente infiltrado propriamente dita, consoante previsto na legislação brasileira, notadamente no art. 53, inciso I, da Lei de drogas.

O agente infiltrado, de certo modo, tem justificativa para excepcionalmente - praticar ato que seja tipificado como delito, quando em situação de extremo perigo, para preservar sua integridade física e resguardar o disfarce.

Já a técnica da entrega vigiada, exatamente por conferir ao agente vigilante, de certa forma, uma maior segurança, porquanto não envolvido diretamente com os agentes da organização criminosa, distanciado de contato pessoal com estes, inadmite o envolvimento do agente destacado, provocando ou cometendo delito. O agente tem o dever de tão somente monitorar a remessa ilícita, podendo, no máximo, interceptá-la ou substituí-la por outra, inócua, no intuito de não permitir o extravio da remessa ilegal.

Dessa maneira, os agentes vigilantes estão proibidos de fazer a entrega das remessas ilícitas, participando efetivamente do ato ilícito, bem como substituir o conteúdo da remessa por algo proibido, o que caracteriza delito e afronta ao direito dos investigados. A substituição eventualmente autorizada e prevista nas convenções que tratam da técnica da entrega vigiada permite, unicamente, a alteração do produto monitorado por outro, desde que lícito. 
Com relação à questão do agente policial provocando o delito, Queralt Vidales Rodriguez ${ }^{329}$ aponta o possível perigo existente nesta prática, explicando que: "se a droga que se vigia pode ser entregue por agentes da polícia, se assim for, estaria se afirmando a máxima de que os fins justificam os meios, coisa perigosa ao extremo, porque poderia chegar a justificar condutas totalmente danosas para um Estado Social e Democrático de Direito".

Já Luis Fernando Rey Huidobro ${ }^{330}$ tratando diretamente da hipótese do agente vigilante ser capaz de provocar $^{331}$ delito, quando da utilização da entrega vigiada, revela que: "Ao meu modo de ver, apesar da figura ter como título circulação ou entrega vigiada, tal fato não deve nos fazer pensar que se permita a entrega de drogas por agentes policiais, para logo seguir seu rastro e deter os adquirentes, porque se assim for, certo que se suporia a perpetração de um verdadeiro delito provocado de tráfico de drogas por parte da polícia, conduta que deve entender-se proibida em um Estado que se proclama Social e Democrático de Direito".

$\mathrm{O}$ agente vigilante dever ser pessoa destacada pela autoridade competente para exercer o mister de monitorar a remessa. E este ato de monitorar consubstancia-se tão somente na vigilância, sem instigar os participantes da suposta organização criminosa a cometer delitos, nem tampouco autorizar que o próprio vigilante cometa delitos. Mesmo na

\footnotetext{
${ }^{329}$ RODRÍGUEZ, Vidales. La última reforma de Codigo Penal em material de drogas en revista General del derecho, año XLIX, $\mathrm{n}^{\circ}$ 583, abril 1993. No texto foi apresentada tradução livre do seguinte trecho original: "se la droga que se vigila puede ser entregada por parte de la policía de ser así, se estaria afirmando la máxima de que el fin justifica los médios, cosa peligrosa em extremo porque podrían llegar a justificarse conductas totalmente danosas para un Estado social y democrático de Derecho".

${ }^{330}$ HUIDOBRO, Luis Fernando Rey. La entrega Vigilada de drogas, Revista del Ministerio Fiscal. No texto foi apresentada tradução livre do seguinte trecho original: "A mi modo de ver, a pesar de que la figura lleve como título la circulación o entrega vigilada, ello no debe hacernos pensar que se permita la entrega de drogas por agentes policiales, para luego seguir su rastro y detener a los adquirentes, ya que de ser así, es cierto que supondría la perpetración de un verdadero delito provocado de tráfico de drogas por parte de la policía, conducta que debe entenderse prohibida y delictiva en un Estado que se proclama social y democrático de derecho".

${ }^{331}$ Revela destacar que observação e acompanhamento não se confundem com estímulo ao cometimento de delitos, não sendo o caso, por isso, de se falar em autorização para infiltração, mesmo incipiente. $\mathrm{O}$ citado estímulo, fazendo nascer no espírito do agente a vontade de delinquir, porém com prévia determinação da impossibilidade de se consumar o crime, caracteriza delito putativo por obra do agente provocador, e o flagrante dele decorrente nada mais é do que flagrante preparado, diferentemente do flagrante esperado, típico da ação controlada. Assim, em relação ao primeiro, diz Nelson Hungria, seu autor nada mais é do que o protagonista inconsciente de uma comédia.
} 
modalidade da entrega vigiada denominada substituição o agente vigilante não está autorizado a cometer delitos, no sentido de introduzir material criminoso na remessa que está sendo vigiada, para incriminar membros da organização, mas apenas substituir uma remessa por outra, que não configure delito.

\subsubsection{Desvirtuamento na aplicação da entrega vigiada como instituto permissivo da perpetuação da criminalidade organizada}

Outro ponto de extrema relevância e que deve ser tratado com cautela, consiste no desvirtuamento na aplicação da entrega vigiada, como instituto permissivo da perpetuação da criminalidade organizada. E esta questão está estritamente vinculada com o problema da autorização da autoridade competente na utilização da entrega vigiada, já que por meio desta, se faz o controle do emprego da técnica.

A entrega vigiada tem, de certa maneira, natureza cautelar. Assim, muitas vezes não há tempo hábil para chegar a autorização da autoridade competente para os executores da medida, de forma prévia ao início do monitoramento. Situação que pode ensejar certos abusos e permissão tácita para o cometimento de delitos, diante da ausência do controle da autoridade competente.

Desta forma, a necessidade de autorização da autoridade competente - em regra a judicial - de forma motivada e, principalmente, delineando os limites da entrega vigiada, mostra-se de extrema relevância para impedir o cometimento de crime por parte dos agentes vigilantes, na medida em que podem deixar de agir, com conduta omissiva, possibilitando a perpetuação de crimes, em face da ausência da autorização, que nada mais representa que uma forma de controle.

Relacionada à questão da autorização, estende-se outra discussão: a do prazo da concessão da medida, que não deve ser deferida por tempo indeterminado. Aliás, 
muito difícil de determinar o momento em que o emprego da técnica perde sua eficiência, principalmente quando utilizada reiteradas vezes na persecução criminal investigativa de uma organização criminosa, porquanto os envolvidos já estejam devidamente identificados e as provas legitimamente recolhidas para embasar a ação penal. Nesta hipótese, a continuidade da vigilância representará, cada vez mais, um caminho para o ilícito, já que encerrado o objetivo pelo qual a técnica investigativa foi adotada.

Ainda, com relação ao lapso temporal, não há prazo estipulado na legislação para a duração e a manutenção da entrega vigiada. Todavia, não deveria ser deferido pelo juiz por tempo indeterminado, embora seja admissível prorrogar-lhe a duração, desde que essas prorrogações sejam justificadamente solicitadas e motivadamente deferidas pela autoridade judicial $^{332}$.

A falta de determinação de lapso temporal para sua realização poderá ampliar, desnecessariamente, a exposição da intimidade da pessoa investigada e dos terceiros sujeitos à entrega vigiada. Além disso, não fixar prazo para concluí-la pode contribuir para a ineficácia da medida por induzir o responsável pela investigação a abandoná-la se verificar que os objetivos traçados inicialmente, como identificar ou prender pessoas mais importantes dentro da organização criminal, não poderão ser atingidos.

Mais difícil ainda é a determinação do momento em que os agentes devem sair do estado de inércia, de pura vigilância, para o estado de atuação, configurando o dever de intervir em determinada remessa, no caso de existir possibilidade iminente de extravio das substâncias monitoradas. A linha que separa a inércia da atuação é tênue e a

\footnotetext{
${ }^{332}$ Para Eduardo Araujo: "Malgrado a ausência de previsão legal de um procedimento, a adoção da ação controlada exige limitações: não poderão os policiais abandonar uma conduta meramente passiva de acompanhamento e observação das atividades investigadas, sob pena de provocação das condutas ilícitas, assim como não poderão praticar atos que comprometam a intimidade e a vida privada dos investigados (interceptação das conversações telefônica e ambiental, invasão de domicílio, busca e apreensão de bens e violação de sigilo bancário e fiscal), salvo mediante prévia autorização judicial. Ainda não poderão os policiais retardar suas condutas por tempo indeterminado, sob pena de ensejar especulações sobre os reais motivos desse retardamento. Embora não seja prevista na lei uma limitação temporal para a diligência de acompanhamento das atividades ilícitas, sua paralisia deve ocorrer quando já satisfeita a "formação das provas" ou o "fornecimento de informações" como preconizado na parte final do artigo $2^{\circ}$, inciso I, da Lei $n^{\circ}$ 9.034/95" (SILVA, Eduardo Araujo da. Op. cit. p. 84).
} 
justificativa da prescindibilidade de atuação, de forma excepcional à regra geral que impõe o dever de agir, pode encobertar, muitas vezes, o cometimento de crime por parte dos agentes vigilantes.

De toda sorte, a regular autorização da autoridade competente pode ter o condão de diminuir a perpetuação de crime, na medida em que retira a discricionariedade do agente policial para atuar ou deixar de atuar na vigilância ou, ainda, ter a justificativa que permaneceu inerte porque estaria supostamente monitorando remessa ilícita, quando, na verdade, pode estar associado ou aliado à organização criminosa que deveria monitorar.

Contudo, mesmo com a adequada autorização da autoridade competente, poderá haver perpetuação de crime por parte dos agentes vigilantes, quando estes estiverem, eventualmente, corrompidos e envolvidos com o crime organizado, praticando uma vigilância deficiente, de forma propositada.

De qualquer modo, há de se distinguir duas situações: a) a autoridade policial realiza tudo o que objetivamente está a seu alcance e, ainda assim, por fato imprevisível, os criminosos consumam o delito; b) a autoridade policial negligencia a vigilância e, portanto, não realiza tudo o que objetivamente está a seu alcance, permitindo que os criminosos venham a consumar o delito.

Nesse sentido, outra discussão se acalora - e aqui há semelhança entre a entrega vigiada e o flagrante diferido - , que consiste na exceção do dever de atuar. Em ambos os casos, a técnica investigativa adotada permite que o agente deixe de agir, num permissivo excepcional de sua condição normal de perseguir o delito. Entretanto, tal exceção não pode servir de guarida a condutas propositadamente omissivas, denotando verdadeira perpetração de crime por parte do agente.

Vale a citação reveladora de Marta Gómez de Liaño Fonseca-Herrero ${ }^{333}$ : "A entrega vigiada implica em uma demora na intervenção estatal perante o cometimento de 
um delito; ou dito de outro modo, as operações de circulação ou entrega vigiada se desenrolam sobre um delito conhecido, mas não imediatamente impedido. Devido à circunstância de que o artigo 262 da Lei de Enjuiciamiento Criminal impõe a obrigação de as autoridades penais de denunciar os fatos puníveis e o artigo 408 do Código Penal sanciona, com pena de inabilitação especial para emprego ou cargo público que, faltando com a obrigação de seu cargo, deixar intencionalmente de promover a persecução dos delitos, se não houvesse incluído no artigo 263 bis da Lei de enjuiciamiento criminal, a investigação mediante operações controladas seria inviável nos dias atuais. A circulação ou entrega vigiada representa uma específica exceção à obrigação que incumbe às autoridades de denunciar os delitos e uma verdadeira causa de justificação do artigo 20.7 do Código Penal, excludente do caráter antijurídico do comportamento omissivo. A justificativa da exceção processual e isenção material no modo normal de proceder das autoridades de persecução perante a constância da execução do delito, e, portanto, da própria entrega vigiada, reside na luta eficaz contra o crime organizado, que inegavelmente reclama da permissão normativa de deixar circular substâncias proibidas a fim de se apreender o maior número de componentes de tais organizações criminosas".

A técnica investigativa da entrega vigiada carece de cuidados para que não haja desvirtuamento em sua aplicação, tornando-se instituto permissivo da perpetuação da criminalidade organizada. Por isso, uma série de condições deve ser observada na sua utilização, no intuito de minimizar as distorções, bem como aumentar seu controle.

\subsection{Sugestões na utilização da entrega vigiada}

Diante de tudo que foi apresentado acerca do instituto da entrega vigiada, bem como do apontamento de seus eventuais problemas e críticas em sua efetiva aplicação, faz-se importante, por outro lado, apresentar algumas sugestões, buscando contribuir com o aperfeiçoamento na utilização dessa nova técnica investigativa. 
Apresentam-se três principais sugestões: 1) a necessidade de adoção de uma legislação específica, que contenha os requisitos mínimos imprescindíveis para a escorreita utilização do instituto; 2) a necessidade de cooperação internacional, uma vez que a técnica surge e tem utilidade de emprego entre países e; 3) a necessidade de harmonização legislativa, para que as normas dos diversos Estados, muitas vezes signatários de acordos internacionais, sejam confluentes.

\subsubsection{Necessidade de observância de condições mínimas na aplicação da entrega vigiada}

Sem dúvida nenhuma, o maior problema na utilização da entrega vigiada está representado pela ausência normativa. Não há na legislação pátria uma lei que trace as regras para o efetivo emprego e detalhamento procedimental para o uso da técnica da entrega vigiada. Por isso, o instituto carece de regulamentação, que pode ser adotada partindo dos conceitos e premissas já existentes acerca do instituto.

Agora, mais importante que expedir uma simples norma, será fazer com que a legislação preveja, em seu bojo, os requisitos mínimos imprescindíveis, de observância obrigatória, para garantir sua eficácia, ao mesmo tempo em que resguarde as garantias fundamentais do investigado.

Para alcançar tal desiderato, partimos da ideia da junção dos requisitos previstos na Convenção de Viena (do qual o Brasil é signatário e que tais requisitos praticamente se repetem nas demais convenções que tratam do tema) e daqueles apontados pela norma brasileira (segundo a corrente que sustenta existir previsão da entrega vigiada na legislação pátria), somados, ainda, a outros requisitos particularizados pela doutrina interna e alienígena. O que significa dizer que alguns desses requisitos não são exigidos expressamente na utilização da entrega vigiada por um país, embora seja em outro e vice versa, mas a somatória de todos eles representa o conjunto de requisitos hipoteticamente ideal a ser adotado. 
Tal lista compreende os seguintes requisitos, que serão examinados de forma particularizada:

1) Possibilidade de utilização somente em crimes graves;

2) Permissão para utilização preferencialmente na fase investigatória;

3) Existência de acordos internacionais que permitam a vigilância entre diversos países (respeitados os princípios fundamentais dos respectivos ordenamentos jurídicos internos);

4) Necessidade de autorização da autoridade competente;

5) Imprescindibilidade de motivação;

6) Autorização individualizada (caso a caso);

7) Observância da proporcionalidade da medida.

\subsubsection{Possibilidade de utilização somente em crimes graves}

Todo procedimento que, ao menos em tese, possa afrontar direito fundamental deve ser utilizado em casos especiais, porquanto contém caráter excepcional. No caso da entrega vigiada esta máxima também deve ser respeitada, restando claro que essa técnica não pode ser empregada para todo e qualquer tipo de crime.

Tal exigência não está prevista na legislação, mas depreende-se do contexto geral da aplicação dos procedimentos especiais de investigação, que carece de uma maior rigidez quando de sua aplicação. Assim, o primeiro passo na utilização do instituto consiste na demarcação dos delitos passíveis de submissão à técnica da entrega vigiada

Na Espanha, o artigo 263 bis da Lei de Enjuiciamiento Criminal, adotou de forma expressa este requisito, ao exigir que para a aplicação da entrega vigiada deve ser 
levado em conta sua necessidade aos fins da investigação, com relação à importância do delito e com as possibilidade de vigilância.

A alusão contida na lei espanhola "importância do delito" deve ser entendida com referência à sua gravidade e permite sustentar, num primeiro momento, que não é em todo caso que será permitido acudir-se do método investigativo da entrega vigiada, senão somente para aquelas hipóteses que se revestem de certa gravidade ${ }^{334}$.

Queralt $^{335}$ expôs que "para uma aplicação mais objetiva a expressão 'revestir-se de uma certa gravidade' deve ser interpretada como equivalente a 'operações (contra o narcotráfico) de envergadura"”.

No entanto, não se pode entender, como parte da doutrina sustenta ${ }^{336}$, que o emprego da entrega vigiada está limitado somente ao monitoramento de remessas ilícitas referentes a entorpecentes ou aos seus precursores químicos ou outros produtos utilizados em sua produção, isto é, aos crimes de tóxicos.

Tal ideia surgiu porque, inicialmente, o emprego da entrega vigiada foi prevista na Convenção de Viena, para combate aos crimes de tóxicos. Todavia, outras convenções internacionais supervenientes à Convenção de Viena vieram a autorizar a utilização do procedimento da entrega vigiada para outros delitos, não devendo mais ser condicionada a sua aplicação exclusivamente aos crimes de tráfico de entorpecentes.

Exemplo da ausência de exclusividade de aplicação para crimes unicamente da Lei de Drogas temos a Convenção Interamericana contra a fabricação e o tráfico ilícitos de armas de fogo, munições, explosivos e outros materiais correlatos -

${ }^{334}$ CABADA, Gumersindo Guinarte. La Circulacion o entrega vigilada de drogas. Cuadernos de política criminal. Edersa Editoriales, 1995. Madrid, p.16

${ }_{335}$ QUERALT, J.J.. La reforma penal y procesal em matéria de tráfico de drogas.

${ }^{336}$ Para essa corrente, não permite a legislação brasileira a entrega vigiada quanto ao transporte de outras substâncias ilícitas ou referente ao tráfico de outros bens ilícitos desvinculado do tráfico de drogas. Exemplificativamente, não se pode autorizar no direito brasileiro a entrega vigiada de pedras preciosas, animais em extinção, armas ou outros objetos ilícitos. A lei brasileira não deixa dúvidas quanto ao seu alcance limitado ao tráfico de entorpecentes. 
Washington de 14/11/1997 (CIFTA), a Convenção das Nações Unidas contra o crime organizado transnacional (Convenção de Palermo) de 15/11/2000 e a Convenção das Nações Unidas contra a corrupção de 31/10/2003.

Todos esses tratados internacionais prevêem a técnica da entrega vigiada e sua utilização em face dos crimes neles mencionados, dentre os quais o tráfico ilícito de armas de fogo, munições, explosivos, remessa de bens e valores monetários etc. Portanto, não se sustenta a aplicação da entrega vigiada tão somente para os crimes de Drogas.

Em suma, o emprego da entrega vigiada, por permitir em certos casos afronta aos direitos do investigado, não deve ser utilizado para investigar qualquer tipo de crime, mas tão somente aqueles graves, entendidos, nesse contexto, quando obrigatoriamente ligados à atuação das organizações criminosas. Do contrário, há perigo de adoção de uma sociedade de vigilância. Além de se operar uma desproporção entre o meio de investigação e o crime perseguido.

\subsubsection{Permissão para utilização preferencialmente na fase investigatória}

A utilização da entrega vigiada não pode ocorrer, indiscriminadamente, em qualquer fase da persecução criminal. Por primeiro de se atentar, conforme lição de Fernando Capez ${ }^{337}$, que a expressão “em qualquer fase da persecução criminal” abrange tanto a fase extrajudicial, o inquérito policial, quanto a judicial, instituída sob a égide do contraditório e da ampla defesa.

Estender a aplicação da técnica investigativa para a fase judicial seria extremamente lesivo ao investigado, por se tratar de procedimento que tem natureza

\footnotetext{
${ }^{337}$ CAPEZ, Fernando. Curso de Direito Penal. vol. 4: Legislação Penal Especial. São Paulo: Saraiva, 2006, p.
} 236. 
nitidamente inquisitiva e, pois, deve ficar reservado à fase do inquérito policial (para aqueles países que possuem a fase do inquérito ou semelhante).

Uma prática, de caráter cautelar e excepcional, que estenda sua aplicação até a fase recursal, acabaria permitindo que procedimentos de caráter inquisitorial prosseguissem durante o desenrolar do processo acusatório, restringindo, desse modo, o exercício do contraditório e da ampla defesa.

Neste diapasão, Sérgio Ricardo de $\operatorname{Souza}^{338}$ ao comentar a utilização do procedimento investigatório contido na Lei de Drogas, que para muitos consiste na própria entrega vigiada, aponta: "a medida investigatória deve ser previamente autorizada pelo juiz competente e, respeitadas as opiniões em contrário, deve desenvolver-se durante a fase das investigações policiais (inquérito policial), devendo essa ser a melhor interpretação para a expressão “fase da persecução criminal" utilizada no caput do artigo 53 da Lei no 11.343/06".

\subsubsection{Existência de acordos internacionais que permitam a vigilância entre diversos países (respeitados os princípios fundamentais dos respectivos ordenamentos jurídicos internos)}

Este requisito surgiu da previsão existente na Convenção de Viena (e acabou consagrado nos demais acordos internacionais que mencionam a figura da entrega vigiada). Ele diz respeito à aplicabilidade da entrega vigiada em âmbito internacional, diante da necessidade da celebração de acordos entre países e da devida observância dos princípios fundamentais do ordenamento interno de cada país envolvido na operação.

Depreende-se da norma da Convenção de Viena o seguinte condicionamento: "se os princípios fundamentais dos respectivos ordenamentos jurídicos internos o permitirem, as Partes adotarão medidas necessárias, dentro de suas possibilidades,

${ }^{338}$ SOUZA, Sergio Ricardo de. A Nova Lei Antidrogas. Editora Impetus, 2 a edição, pág. 144. 
para que se possa recorrer, de forma adequada, no plano internacional, à entrega vigiada com base nos acordos e ajustes mutuamente negociados".

Conforme assinalado por Carlos Enrique Edwards ${ }^{339}$, a entrega vigiada foi criada para combater a narcocriminalidade, que supõe o tráfico de remessa de drogas de um país para outro: "O narcotráfico é um fenômeno internacional que não reconhece fronteiras, motivo pelo qual um carregamento de entorpecentes pode circular por dois ou mais países, uma vez que essas organizações criminosas têm representantes em cada um de seus Estados por onde os entorpecentes circulam”.

Entretanto, somente será possível utilizar a entrega vigiada entre países para o combate ao crime organizado, se houver ajustes celebrados entre as partes envolvidas (isto é, entre os Estados), respeitados os princípios fundamentais dos respectivos ordenamentos jurídicos internos. A partir do momento em que uma norma interna vier ao encontro da norma de outro país, sendo, portanto, conflitantes, restará prejudicada a utilização do instituto entre tais Estados.

Agora, um país pode perfeitamente instituir no âmbito interno a previsão da entrega vigiada em sua legislação pátria, porém não ser signatário de nenhuma convenção internacional que preveja a mesma figura. Ocorre que a utilização do procedimento em âmbito internacional será dificultoso, diante da ausência de normas expressas de cooperação entre os países, consubstanciado no liame jurídico representado pelo acordo.

Não haverá dúvida sobre a possibilidade de aplicação da técnica se o país for signatário da convenção e ainda repetir os dispositivos dessa previsão em sua legislação interna, ainda que alterando, acrescentando ou suprimindo parte de seu teor. Mas, poderá obviamente aplicá-la internamente, bem como participar da investigação em parceria com outros países, com base no acordo celebrado.

\footnotetext{
${ }^{339}$ EDWARDS, Carlos Enrique. El arrepentido, el agente encubierto y la entrega vigilada. Modificación a la Ley de Estupefacientes. Análisis de la ley 24.424, Editora Ad Hoc, Buenos Aires, p.107. No texto foi apresentada tradução livre do seguinte trecho original: "El narcotráfico es un fenómeno internacional que no reconoce fronteras, motivo por el cual un cargamento de estupefacientes puede circular por dos o más países, ha que estas organizaciones delictivas tienen representantes en cada uno de los Estados por donde el estupefaciente circula."
} 
De toda forma, é crucial a existência de acordos internacionais que permitam a vigilância entre diversos países, respeitados os princípios fundamentais dos respectivos ordenamentos jurídicos internos de cada um deles.

6.2.1.4 Necessidade de autorização da autoridade competente

A entrega vigiada consiste em uma exceção específica do dever que incumbe às autoridades de denunciar os delitos, interrompendo a situação de flagrância. Tolera-se, mediante vigilância, a circulação de gêneros proibidos, o que difere da regra geral de repressão do delito conhecido. Tais operações excepcionam as regras do Estado de Direito sob este aspecto de permitir a continuidade delitiva, e por essa razão é que se defende o caráter excepcional do meio de investigação.

Ademais, a entrega vigiada se presta para a coleta de provas no enfrentamento do crime organizado. É preciso ultrapassar a situação de incerteza sobre as remessas ilícitas, vigiando-as e alcançando o cerne da organização, além de descobrir seu modus operandi.

Por tais motivos deve haver autorização para a execução da técnica investigativa, exatamente pela excepcionalidade acima narrada, consistente em se permitir a continuidade de um delito sem a obrigatória atuação repressora imediata.

Qualquer investigação mediante a entrega vigiada precisa de uma autorização, independentemente de quem seja a autoridade competente. Ademais, a concreta materialização da entrega vigiada reclama a intervenção de sujeitos executores no intuito de satisfazer, através da vigilância do curso do envio, a própria finalidade da operação. 
Conclui-se, portanto, que a entrega vigiada exige autorização da autoridade competente, até mesmo para eximir o agente executor de seu dever de interpelar a ação ilícita em curso. A necessidade de autorização tem sua razão de ser justamente nessa situação de desincumbir e proteger o próprio agente executor, além de evitar abusos, diante da elevada discricionariedade que teria o executor em justificar a diligência, ou a falta dela, sob pretexto de estar monitorando remessas ilícitas.

Dessa maneira, a autorização da autoridade competente tem duplo efeito: por um lado, o de eximir o agente executor da técnica investigativa de seu dever ordinário de intervenção durante a situação de flagrância e, por outro, o de controlar a atuação deste mesmo agente, porque somente poderá deixar de atuar, permitindo o cometimento de um delito em andamento, quando existente essa autorização. Do contrário, estará cometendo ato ilícito, não podendo justificar sua inércia (salvo em casos excepcionais, de uma autorização emergencial pelo próprio agente executor, a ser ratificada posteriormente pela autoridade competente).

Demonstrada que a autorização é providência indispensável para qualquer investigação mediante o emprego da entrega vigiada, resta saber quem se institui como autoridade competente para sua concessão e de que maneira se dá a ordem.

A autoridade competente dependerá do momento da adoção da técnica investigativa e de sua tipologia. Sem a devida reflexão, inclina-se, de início, em defender a ideia de que somente o juiz seria o legitimado para autorizar a entrega vigiada ${ }^{340-341}$. Trata-se

${ }^{340} \mathrm{Na}$ Espanha houve discussão se além do juiz, outras autoridades poderiam autorizar a medida: "En España, la
determinación de las autoridades penales competentes para autorizar una investigación mediante la técnica de
la circulación controlada, fue objeto de posiciones enfrentadas durante los trabajos parlamentarios previos a la
promulgación, tanto de la LO $8 / 1992$, de 23 de diciembre, como de la LO $5 / 1999$, de 13 de enero. No obstante lo
anterior, los debates parlamentarios, no concluyeron con una clara delimitación legal competencial de las tres
autoridades, sino que, antes al contrario, finalizaron con la aprobación de la triple competencia, con la ayuda de
los principios inspiradores del proceso penal y, en conformidad absoluta con el régimen constitucional de
protección de los derechos fundamentales afectados" (FONSECA-HERRERO, Marta Gómez de Liaño.
Criminalidad Organizada Y medios extraordinarios de investigación. Editorial Colex, Madrid: 2004, p. 312/313).
341 Gumersindo Guinarte Cabada à época da inserção do artigo 263 bis na legislação espanhola, que introduziu a
figura da entrega vigiada, comentou os riscos que adviriam da expansão da legitimidade para autorização deste
procedimento tão extraordinário para outras autoridades que não a judicial (CABADA, Gumersindo Guinarte. La
Circulacion o entrega vigilada de drogas. Cuadernos de política criminal. Edersa Editoriales, 1995. Madrid,
p.12). No mesmo diapasão, Muñoz Conde apontou que "a possibilidade de autorização policial da entrega vigiada
pode contribuir para enormes abusos e entende que a falta de reserva para as autoridades judiciais, quanto à 
de uma tendência natural, de seguir o procedimento geralmente adotado em técnicas investigativas, que confere ao juiz o poder de concessão de tais medidas.

Porém, no caso da entrega vigiada e em conformidade com o regime processual penal e com a natureza jurídica da técnica, que consiste em vigilância (que, em regra, não gera afronta direito do investigado), de se permitir uma tríplice autoridade concedente da medida, de acordo com o momento de sua adoção e sua tipologia.

Assim como previsto na Lei de Enjuiciamiento Criminal espanhola ${ }^{342}$, o Juiz, o Ministério Público e os Chefes da Polícia Judiciária detêm competência para autorizar a circulação da remessa monitorada.

faculdade de autorizar as entregas vigiadas, constitui o aspecto mais importante do novo regulamento espanhol" (CONDE, Muñoz. Derecho penal, parte especial, $9^{a}$ edição, Valencia, 1993, p. 507). Também Queralt expressa seu inconformismo com este aspecto da nova regulamentação, afirmando quando qualifica de "sumamente curioso" que: "supera o limite do assombro imaginar que podem existir atuações policiais sem que delas tenha ciência a autoridade judicial" e conclui que a subtração destas atividades ao controle judicial é uma imprudência (Queralt apud CABADA, Gumersindo Guinarte. La Circulación o entrega vigilada de drogas. Cuadernos de política criminal. Edersa Editoriales, 1995. Madrid, p.12. Tradução livre do texto original: "supera el umbral del asombro imaginar que puedan existir actuaciones policiales sin que de ellas tenga cumplida cuenta la autoridad judicial"). Diez Ripolles também criticou a possibilidade de autorização da entrega vigiada, conforme prevista na legislação espanhola, pelos agentes da polícia recordando que o mais surpreendente desta permissiva legal consiste no fato da Espanha, durante o período de discussão da Convenção de Viena para estabelecimento de um texto internacional, ter se alinhado aos países que defenderam veementemente a necessidade de intervenção da autorização judicial, uma vez que este procedimento suporia deixar de perseguir delitos já consumados (RIPOLLÉS, Díez. Los delitos relativos a drogas tóxicas, estupefacientes y substancias psicotrópicas, Madrid, 1989).

${ }^{342} 263$ bis. 1. El Juez de instrucción competente y el Ministerio Fiscal, así como los Jefes de las Unidades Orgánicas de Policía Judicial, centrales o de ámbito provincial, y sus mandos superiores podrán autorizar la circulación o entrega vigilada de drogas tóxicas, estupefacientes o sustancias psicotrópicas, así como de otras sustancias prohibidas. Esta medida deberá acordarse por resolución fundada, en la que se determine explícitamente, en cuanto sea posible, el objeto de autorización o entrega vigilada, así como el tipo y cantidad de la sustancia de que se trate. Para adoptar estas medidas se tendrá en cuenta su necesidad a los fines de investigación en relación con la importancia del delito y con las posibilidades de vigilancia. El Juez que dicte la resolución dará traslado de copia de la misma al Juzgado Decano de su jurisdicción, el cual tendrá custodiado un registro de dichas resoluciones. También podrá ser autorizada la circulación o entrega vigilada de los equipos, materiales y sustancias a los que se refiere el artículo 371 del Código Penal, de los bienes y ganancias a que se hace referencia en el artículo 301 de dicho Código en todos los supuestos previstos en el mismo, así como de los bienes, materiales, objetos y especies animales y vegetales a los que se refieren los artículos 332, 334, 386, 566, 568 y 569, también del Código Penal.(...) 3. El recurso a la entrega vigilada se hará caso por caso y, en el plano internacional, se adecuará a lo dispuesto en los tratados internacionales. Los Jefes de las Unidades Orgánicas de la Policía Judicial centrales o de ámbito provincial o sus mandos superiores darán cuenta inmediata al Ministerio Fiscal sobre las autorizaciones que hubiesen otorgado de conformidad con el apartado 1 de este articulo y, si existiese Procedimiento judicial abierto, al Juez de instrucción competente. 
Quando existir processo penal em curso, e for excepcionalmente necessária a medida nesta fase, porque a regra deve ser o emprego da técnica apenas na fase investigativa, a autorização deve ser dada pelo juiz. Também quando a adoção da entrega vigiada resultar em afronta a direito fundamental (em qualquer fase que seja deflagrada, isto é inquisitiva ou processual), como por exemplo, no caso da entrega vigiada na modalidade substituição, o juiz será a autoridade competente para autorizar a medida. Ainda, no caso de entrega vigiada internacional, competirá apenas ao Juiz de Direito a competência para autorização do monitoramento, já que envolve atos entre Estados.

Dessa forma, de se notar que, majoritariamente a medida deve mesmo ser autorizada pelo Juiz, a quem, regra geral, competirá a análise e o deferimento do emprego desse meio de investigação. No entanto, haverá casos em que outras autoridades terão competência para autorizar a medida, seja com ou sem a ratificação posterior da autoridade judicial.

No âmbito da investigação preliminar (desde que não haja possibilidade de desrespeitar direito fundamental do investigado) o Ministério Público, poderá utilizar a técnica. A competência do Ministério Público para conceber a entrega vigiada deve estar circunscrita ao regime legal que possibilita a execução de seu próprio procedimento preliminar de investigação. Neste lhe é facultado a adoção de medidas de investigação, porém, somente quando não constitua uma atuação restritiva de direitos fundamentais, uma vez que em matéria de limitação desses direitos o juiz deve ter competência exclusiva.

A competência reconhecida ao Ministério Público para, no âmbito da investigação preliminar, utilizar a prática da entrega vigiada encontra uma clara limitação nas operações que necessitam de prévia abertura ou substituição do conteúdo dos pacotes postais e das correspondências, as quais seguem reservadas ao monopólio judicial.

Assim, quando no curso da investigação preliminar o Ministério Público entender conveniente para os objetivos da persecução a realização de uma entrega vigiada, mas se a operação estiver protegida pelo sigilo das comunicações (e para efeitos de 
comprovação ou substituição do conteúdo do envio houver a necessidade de sua abertura), será obrigatória a intervenção da autoridade judicial, por meio de decisão fundamentada, determinando a autorização da técnica, a ser requerida previamente pelo Parquet.

Por fim, os Delegados da Polícia Judiciária (e aqui deve haver uma interpretação em sentido amplo, para incluir nestes agentes as Autoridades Aduaneiras desta qualidade $^{343}$ podem autorizar a entrega vigiada, desde que haja urgência na medida, configurada pela cautelaridade e impossibilidade de se aguardar a autorização judicial, em situações excepcionais de iminente extravio da remessa. Todavia, nesse caso, deverá haver a imediata comunicação à Autoridade Judicial, na primeira oportunidade, para que a mesma possa ser convalidada.

Afora os casos excepcionais, que se permite a autorização de outras autoridades que não a judicial, sob a ratificação desta, caberá à autoridade policial representar ou ao membro do Parquet requerer à autoridade judicial o emprego da entrega vigiada para monitorar remessas ilícitas, no intuito de coletar provas e desvendar os membros da organização criminosa.

\subsubsection{Imprescindibilidade de motivação da decisão que autoriza a entrega vigiada}

\footnotetext{
${ }^{343}$ De acordo com dispositivos do Decreto $n^{\circ} 1.789$, de 12 de janeiro de 1996, que dispõe sobre o Intercâmbio de Remessas Postais Internacionais, disciplina seu controle aduaneiro e dá outras providências, os "Delegados" alfandegários possuem competência para autorizar medidas de controle sobre remessas de bens, a saber: Art. 12. O controle aduaneiro é exercido sobre todas as remessas, qualquer que seja o destinatário ou o remetente, tenham ou não finalidades comerciais os bens nelas contidos, a partir da abertura da mala vinda do exterior ou até o seu fechamento quando a ele destinada. $\S 1^{\circ}$ A Alfândega, respeitada a competência e as atribuições da Administração Postal, controlará o fluxo das malas postais internacionais no território aduaneiro. $\S 2^{\circ} \mathrm{A}$ abertura das malas postais nacionais contendo remessas destinadas ao exterior, selecionadas para fiscalização aduaneira, e das malas postais internacionais será feita na presença de funcionário da Alfândega. $\S 3^{\circ}$ Os chefes das repartições aduaneiras tomarão providências para que, sem perda da qualidade do controle aduaneiro, as atividades da fiscalização não constituam embaraço ao tráfego postal; Art. 13. Dependem de autorização da Alfândega: I - a abertura das malas procedentes do exterior; II - a saída, a qualquer título, dos correios permutantes, de remessas ainda não liberadas pela fiscalização; III - a expedição, a reexpedição, a devolução à origem ou a entrega de remessas ao destinatário; IV - a abertura de remessa; V - a entrada de pessoas e veículos nos recintos postais alfandegados, exceto as que neles trabalhem e os que estejam a serviço da Alfândega ou da Administração Postal.
} 


\begin{abstract}
Deve a autorização da autoridade competente vir motivada ${ }^{344}$, justificando, detalhadamente, as razões do deferimento da medida, em especial com a determinação do objeto a ser monitorado, quando possível.
\end{abstract}

A superveniente legislação que tratar da entrega vigiada deve prever a exigência da motivação ${ }^{345}$. Não basta para a utilização de tal meio de obtenção de provas a simples autorização da autoridade competente, sem discriminar a forma e razões dessa autorização. Até porque a autorização ocorrerá, via de regra, em casos que houver elevada possibilidade de afronta a direito fundamental.

Na Espanha houve a mesma discussão quando da inserção da entrega vigiada no artigo 263 bis da Lei de Enjuiciamiento Criminal. Uma das emendas (que não foi aprovada) pretendia que a norma incorporasse o seguinte parágrafo: “as autorizações concedidas deverão ser registradas documentalmente no juizado da instrução ou do Ministério

\footnotetext{
${ }^{344}$ Conforme Antonio Scarance Fernandes: "Não há dúvida de que a exigência de motivação abrange todas as decisões relevantes do processo, definitivas ou interlocutórias, principalmente quando estas afetem direitos individuais (FERNANDES, Antonio Scarance. Processo Penal Constitucional, $4^{\mathrm{a}}$ edição, Editora Revista dos Tribunais, 2007, p. 136). Rogério Lauria Tucci atenta para a importância da motivação, pois é mediante ela que "o magistrado pronunciante de ato decisório mostra como apreendeu os fatos e interpretou a lei que sobre eles incide, propiciando, com a indispensável clareza, lógica e precisão, a perfeita compreensão da abordagem de todos os pontos questionados e, conseqüente e precipuamente, a conclusão atingida". Segundo Antonio Magalhães Gomes Filho "o juiz tem o dever de motivar as suas decisões porque a motivação é "um diálogo que nasce entre as partes e com as partes, que são destinatárias da decisão. Como uma espécie de prestação de contas desse modo de atuar, a motivação das decisões judiciais adquire uma conotação que transcende o âmbito próprio no processo para situar-se, portanto, no plano mais elevado da política, caracterizando-se como o instrumento mais adequado ao controle sobre a forma pela qual se exerce a função jurisdicional" (FILHO, Antonio Magalhães Gomes. A motivação das decisões penais, Editora Revista dos Tribunais, 2001, São Paulo, p. 79/80).

${ }^{345}$ Aqui também é preciso fazer referência a outra garantia fundamental, necessária para que a iniciativa oficial não se converta em porta aberta ao julgamento parcial: a motivação das decisões, imposta pelo art. 93, IX, da Constituição. A obrigatoriedade de apresentação das razões da utilização dos poderes instrutórios representa, de uma lado, forte estímulo à efetiva imparcialidade, impedindo escolhas subjetivas, pois a exigência de explicitação do iter decisório que induz a que nele apenas sejam considerados dados objetivos. De outro, pode também a motivação constituir ponto de partida para a descoberta de eventuais motivos subjetivos, que tenham influenciado a intervenção judicial, evidenciando um possível pré-julgamento da causa. (FILHO, Antonio Magalhães Gomes, A motivação das decisões penais, p. 99) Assim, ainda lembrando a excelente monografia de Marcos Zilli, o mesmo Estado Democrático de Direito que inspira a necessidade de um "poder-dever" instrutório do julgador, tendente a uma profícua aplicação do direito substantivo, exige que aquele se materialize por intermédio de uma decisão devidamente fundamentada, permitindo, dessa forma, que os sujeitos processuais parciais tenham conhecimento das justificativas invocadas para uma postura mais ativa do juiz (ZILLI, Marcos Alexandre Coelho. A iniciativa instrutória cit., p. 156). Por último, mas não menos importante, é assegurar que a iniciativa judicial não comprometa o pleno exercício do contraditório. E que os poderes do juiz em matéria de prova, além de excepcionais e residuais, devem ser exercidos dentro do contexto das atividades desenvolvidas pelas partes (LINA CACENI, Poteri dufficio in materia probatoria e imparcial itã dei giudice Penale. p. 85-86).
} 
Fiscal (que representa aqui o nosso Ministério Público), respectivamente, fazendo constar a pessoa autorizante, assim como as pessoas e quantidades autorizadas”.

Um requisito com esse teor, a ser exigido na legislação brasileira, pode contribuir não apenas para evitar que a técnica seja utilizada para fins distintos dos previstos, como também para delimitar com precisão o alcance de outro requisito exigido, qual seja: a singularidade da autorização caso a caso, com a detalhada motivação.

A lei argentina - Lei $n^{\circ} 24.424$ - contempla os requisitos exigidos para a entrega vigiada, impondo, da mesma forma que a segunda parte do artigo 11 da Convenção de Viena, que a autorização deva dispor através de resolução fundamentada, acerca da qualidade (espécie) e a quantidade da substância vigiada, assim como seu peso.

Carlos Enrique Edwards ${ }^{346}$ comentando a norma argentina alertou que "a autorização para a entrega vigiada não pode ser ordenada por um simples provimento, pois demanda, inexoravelmente, uma resolução fundada, advertindo, ainda, que o artigo 123 do Código de Processo Penal Argentino determina que a decisão deverá ser motivada, sob pena de ilegalidade".

E finaliza referido autor ${ }^{347}$ que a "adoção de uma decisão desse tipo como a de não ordenar nem o sequestro da remessa e nem a detenção de seus transportadores, deve vir rodeada de uma série de formalidades que assegurem a seriedade e a transparência de tal resolução, com a finalidade de se evitar qualquer tipo de abuso, por isso a necessidade de uma ordem minuciosa, fundamentada que preveja o sentido e alcance da autorização”.

Portanto, deve a decisão do Juiz que autorize a entrega vigiada indicar a substância que está sendo transportada, bem como a sua quantidade, na medida do possível. Consoante Delgado ${ }^{348}$ : "Este requisito resulta relevante para o exercício de um controle

${ }^{346}$ EDWARDS, Carlos Enrique. El arrepentido, El agente Encubierto y la entrega Vigilada. Ad Hoc, Buenos Aires, p. 112.

${ }^{347}$ Idem.

${ }^{348}$ MARTIN, Joaquín Delgado. La Criminalidad Organizada, J.M. Bosch editora Barcelona, 2001, p.68. 
adequado da entrega vigiada, especialmente para evitar atuações ilícitas com relação ao objeto da operação".

Além disso, os sujeitos passivos, aquelas pessoas sobre as quais recaiam indícios de culpabilidade por ato de remessas ilícitas, devem estar minimamente identificadas, em todo o momento, para não converter a investigação numa prospecção inquisitorial contra a delinquência associativa.

\subsubsection{Autorização individualizada (caso a caso)/Análise do caso concreto}

Relacionada com a ideia da motivação entrelaça-se a exigência da autorização individualizada. Embora semelhantes, são requisitos distintos. A motivação diz respeito à necessidade da transparência da autorização, justificando as razões de seu deferimento, enquanto a individualização consiste na análise da necessidade de aplicação da medida para cada caso concreto. E, por conta disso, para cada remessa ilícita, ainda que referente ao mesmo grupo de suspeitos envolvidos ou membros da mesma organização criminosa, faz-se necessária uma autorização específica.

Com relação à individualização, não se pode admitir decisões amplas. Necessário que a autoridade competente analise cada caso individualmente, indicando os elementos concretos dos autos que justifiquem a utilização da entrega vigiada, para aquela operação específica. E, a partir desse exame, autorize o monitoramento para aquela remessa específica.

Aliás, esta é a orientação da Convenção de Viena, no sentido de que as decisões sobre a entrega vigiada sejam proferidas, de acordo com a análise de cada caso em concreto, quando dispôs em seu texto, no artigo 11, item 3: “As decisões de recorrer à entrega vigiada serão adotadas, caso a caso, e poderão, quando necessário, levar em conta ajustes 
financeiros e entendimentos relativos ao exercício de sua competência pelas partes interessadas".

Há a mesma exigência na lei espanhola ${ }^{349}$. Conforme ensina Delgado ${ }^{350}$ : “deve concorrer uma autorização individualizada de cada operação, caso a caso. Assim, se exige expressamente no primeiro inciso do ponto 3, do artigo 263 bis, da Lei de Enjuiciamiento Criminal, com a finalidade de excluir a concorrência de uma autorização genérica a determinada unidade ou a certo grupo de casos. Em definitivo, cada remessa deverá ser objeto de uma autorização individualizada".

A exigência da autorização individualizada caso a caso, prevista na lei espanhola e em outras leis estrangeiras é reprodução fiel da exigência prevista na Convenção de Viena. Na verdade, tal exigência já estava inserida, no Convênio de Schengen $^{351}$ de 1985 , considerado o marco inicial para a futura materialização da Convenção de Viena.

O acordo de Schengen dispõe que a utilização do procedimento da entrega vigiada deverá ser submetida, em cada caso, a uma autorização prévia da parte contratante afetada, isto é, do Estado em cujo território serão introduzidas as substâncias ilícitas ou por aqueles em que estas substâncias irão circular para outro destino.

\footnotetext{
${ }^{349}$ Artigo 263 bis, Item 3, da Ley de Enjuiciamiento Criminal espanhola: 3) El recurso a la entrega vigilada se hará caso por caso y, en el plano internacional, se adecuará a lo dispuesto en los tratados internacionales. Los Jefes de las Unidades Orgánicas de la Policía Judicial centrales o de ámbito provincial o sus mandos superiores darán cuenta inmediata al Ministerio Fiscal sobre las autorizaciones que hubiesen otorgado de conformidad con el apartado 1 de este articulo y, si existiese Procedimiento judicial abierto, al Juez de instrucción competente.

350 MARTIN, Joaquín Delgado. La Criminalidad Organizada, J.M. Bosch editora Barcelona, 2001, p. 68. Tradução livre do seguinte trecho original: "Debe concurrir una autorización individualizada de cada operación, caso por caso. Así se exige expresamente en el primer inciso del punto 3 del art. 263 bis LECR, con la finalidad de excluir la concurrencia de una genérica a determinada unidad y/o a cierto grupo de casos. En definitiva, cada 'remesa' deberá ser objeto de una autorización que reúna los restantes requisitos que se enuncian la continuación".

${ }^{351}$ A entrega vigiada foi contemplada pelo artigo 73, do Convênio de Schengen, de 14 de junho de 1985, prevendo o seguinte: "1. - De conformidad con su Constitución y su ordenamiento jurídico, las partes contratantes se comprometen a tomar medidas que permitan las entregas vigiladas en el tráfico ilícito de estupefacientes y sustancias psicotrópicas.2. - La decisión de recurrir a entregas vigiladas se adoptará en cada caso concreto basándose en una autorización previa de la Parte contratante de que se trate.3. - Cada parte contratante conservará la dirección y el control de las actuaciones en su territorio y estará autorizada a intervenir".
} 
Obviamente não se pode concluir que essa exigência possa ser excluída para os casos de circulação monitorada pela entrega vigiada dentro do território do Estado.

Em que pese a previsão da exigência de autorização individualizada caso a caso para as remessas entre Estados diversos, faz-se imperiosa a interpretação extensiva desse requisito, no sentido de entendê-lo igualmente exigível no âmbito interno, uma vez que a ausência dessa autorização específica tornar-se-ia uma carta branca, uma licença de atuação muito ampla para os agentes do Estado, dando margem a possíveis abusos.

Gumersindo Guinarte Cabada ${ }^{352}$ - ao tratar da questão relativa à indispensabilidade de autorização individualizada caso a caso para a entrega vigiada - afastou de vez qualquer pensamento que pudesse sustentar a dispensa da autorização particularizada em cada caso. Indagou o autor: "Pensemos, por exemplo, na hipótese de uma organização destinada ao narcotráfico que, a partir de um país estrangeiro, envia regularmente à Espanha (no caso o País sede do autor) determinadas quantidades de uma mesma droga e por meio de um mesmo canal de envio (podendo ser o correio). Neste cenário, bastaria uma única autorização para dar cobertura a todas as entregas?"

E o mesmo autor, tomando por base sua própria indagação, respondeu: “Em minha opinião, e levando-se em conta a finalidade que esse requisito tem como meio de controle, e, por conseguinte, como limite ao uso do mecanismo das entregas vigiadas, faz-se necessária uma interpretação restrita que obriga a exigir para cada conduta independente (é dizer, para cada ação de introdução) uma autorização singular”.

Dessa maneira, o entendimento desse autor, implica a exclusão definitiva das autorizações de caráter genérico. Nem bastará, ainda, uma autorização específica para uma pluralidade de remessas monitoradas pela entrega vigiada. Atuando de forma diversa estar-seia burlando a garantia para o correto uso deste mecanismo de investigação.

\footnotetext{
352 CABADA, Gumersindo Guinarte. La Circulación o entrega vigilada de drogas. Cuadernos de política criminal. Edersa Editoriales, 1995. Madrid, p.12
} 


\subsubsection{Observância da proporcionalidade da medida}

A utilização desmedida da entrega vigiada, alcançando crimes de gravidade reduzida, pode violar injustificadamente direito individual, tendo em vista o descompasso entre o crime cometido e a potência que a medida representa para combatê-lo.

Contudo, nessa situação de confronto, prudente valer-se do princípio da proporcionalidade. Consoante ensinamento de Antonio Scarance Fernandes ${ }^{353:}$ "haverá observância do princípio da proporcionalidade se predominar o valor de maior relevância, evitando-se, assim, que se imponham restrições aos direitos fundamentais, se comparadas com o objetivo a ser alcançado".

Assim, dentre os requisitos do emprego da entrega vigiada, encontra-se o dever da autoridade competente observar a necessidade, a adequação e a proporcionalidade da medida: trata-se, aqui, da admissão legal da regra da proporcionalidade e de todos os seus elementos ${ }^{354}$.

$\mathrm{Na}$ verdade, Robert Alexy seguido pela doutrina brasileira apresenta estes três elementos da proporcionalidade ${ }^{355}$ : adequação, necessidade, proporcionalidade em sentido estrito.

A adequação significa que o meio utilizado deve ser capaz de fomentar a obtenção do resultado pretendido. A necessidade, ainda segundo Virgilio Afonso da Silva,

\footnotetext{
${ }^{353}$ FERNANDES, Antonio Scarance. Processo Penal Constitucional. $3^{\mathrm{a}}$ edição, Revistas dos Tribunais, 2002, p. 55 .

${ }^{354}$ Sobre a proporcionalidade, a par dos vários estudos que já tomaram corpo no país, interessante verificar as ideias apresentadas por Luís Virgílio Afonso da Silva.

${ }^{355}$ Para que se possa falar sobre proporcionalidade, como lembra Madeira, citando Robert Alexy (Guilherme Madeira Dezem. Da Prova Penal. Campinas: Editora Millenium, 2008, p.107), devem-se destacar dois aspectos, ou seja, a caracterização da proporcionalidade como regra e os elementos que a compõem. Ao tratar de distinguir as regras dos princípios, esse autor afirma que enquanto os princípios são mandamentos de otimização (Optimierungsordnung) as regras "expressam deveres definitivos e são aplicadas por meio de subsunção" (SILVA, Luis Virgilio Afonso da. O Proporcional e o Razoável. RT 798, página 25). Dentro dessas análises, a proporcionalidade na obra de Alexy se insere como regra e não como princípio.
} 
deve ser entendida quando "a realização do objetivo perseguido não possa ser promovida, com a mesma intensidade, por meio de outro ato que limite, em menor escala, o direito fundamental atingido"356. Por fim, a proporcionalidade em sentido estrito significa "o 'sopesamento' entre a intensidade da restrição ao direito fundamental atingido e a importância da realização do direito fundamental que com ele colide e que fundamenta a adoção da medida restritiva $^{357,}$.

Deverá a autoridade competente verificar se a produção probatória requerida é capaz (em tese) de obter o resultado desejado; verificar se há outra medida menos violadora que produz o mesmo resultado; e verificar os valores em conflito envolvidos para a análise do meio de prova requerido. Deve-se examinar se mais interessante permitir a continuidade do delito, monitorando-o ou interrompê-lo, cessando sua perpetração.

No emprego da entrega vigiada, notadamente quando da possibilidade de afronta a direito fundamental, deve prevalecer a atuação do chamado princípio da proporcionalidade $^{358}$, no sentido de se defender a utilização da vigilância e do monitoramento das remessas ilícitas, de forma excepcional, expressamente regulamentada, sob o controle de uma autoridade competente, para que não haja violação das garantias do investigado ${ }^{359}$. A

\footnotetext{
${ }^{356}$ Op cit. p. 38.

${ }^{357}$ Op cit. p. 40.

${ }^{358}$ Neste sentido, Luis Fernando Rey Huidobro, Fiscal del Tribunal Superior de Justicia de Navarra, Madrid, no artigo em que trata da entrega vigiada acastelou também a excepcionalidade que a técnica da entrega vigiada representa ao escrever: "De todo modo, parece deduzir-se claramente de uma interpretação teleológica do preceito (não olvidemos que se introduziu na Lei de Enjuiciamiento Criminal para lutar de um modo efetivo contra a alta criminalidade relacionada com o narcotráfico), que o recurso à entrega vigiada, como medida excepcional que é, deve guardar uma proporcionalidade com a infração penal a qual se dirige a medida" (HUIDOBRO, Luis Fernando Rey. La entrega vigilada de drogas: El artículo 263 bis de la Ley de Enjuiciamiento Criminal. Revista Del Ministerio Fiscal, Julio-Diciembre 1995, número 2, pág. 201). No texto foi apresentada tradução livre do seguinte trecho original: "De todos modos, parece deducirse claramente de una interpretación teleológica del precepto (no olvidemos que se introduce en la LECRr. para luchar de un modo efectivo contra la alta criminalidad relacionada con el narcotráfico), que el recurso a la entrega vigilada como medida excepcional que es, debe guardar una proporcionalidad con la infracción penal a la que va dirigida".

${ }^{359}$ Para Silva Franco, os instrumentos legais colocados fartamente à disposição da autoridade policial mesmo que não demonstrem qualquer aptidão para os fins pretendidos, geram na população intranquilizada a expectativa de que os problemas da criminalidade (de massa e não a organizada) e da violência possam ser submetidos ao necessário controle estatal. Porém, a política de segurança própria de um Estado Democrático de Direito não pode se fundar apenas na efetividade da ação policial, mas também no respeito às garantias penais e constitucionais. (FRANCO, Alberto Silva; NINNO, Jefferson; JÚNIOR, José Silva. Leis penais especiais e sua interpretação jurisprudencial. $7^{\mathrm{a}}$ ed. São Paulo: RT, 2001, v.1, p. 578).
} 
medida extrema somente será adequada, segundo Antonio Scarance Fernandes"360 "se a restrição a direito fundamental se mostrar apta a realizar o fim por ela visado, observadas a necessidade, a adequação e a proporcionalidade em sentido estrito”.

\subsubsection{Cooperação internacional}

$\mathrm{Na}$ atual conjectura internacional ${ }^{361}$ é extremamente difícil - quiçá impossível - a qualquer Estado combater, isoladamente e com sucesso, a criminalidade organizada. A evolução do crime organizado ganhou contornos internacionais (deixando de ser um problema local), ultrapassando as barreiras físicas de perpetuação de ilícitos dentro de um único Estado.

Torna-se fundamental a abordagem organizada e multilateral entre países, definindo tarefas mais racionais e determinando os materiais disponíveis em cada Estado, por meio de uma cooperação mais estreita ${ }^{362}$, principalmente entre os serviços de inteligência e segurança dos Estados, com programas comuns que permitam uma troca efetiva, a fim de prevenir e neutralizar a atividade criminosa organizada. Surge, assim, a cooperação jurídica internacional $^{363}$.

\footnotetext{
${ }^{360}$ FERNANDES, Antonio Scarance. Processo Penal Constitucional. São Paulo: RT, 2002.

361 Neste diapasão, Carolina Glayder Rabelo aponta que: "com o advento da "dinâmica globalizada", particularmente a redução dos entraves ao movimento de pessoas, bens e transações financeiras transfronteiriças, os grupos internacionais do crime organizado têm expandido a sua penetração. Muitos dos grupos criminosos não ousam poupar despesas para corromper e chantagear governos e autoridades. Assim é que se pensa numa Cooperação Jurídica Internacional mais ajustada, visando coibir as atividades criminosas transnacionais. Nesse sentido, entende-se que, caso os Estados se unam de forma homogênea, utilizando instrumentos como a cooperação jurídica, serão desenvolvidas maneiras de solucionar, remediar e prevenir a atuação criminosa transnacional" (RABELO, Carolina Glayder. A cooperação jurídica internacional e o crime organizado transnacional. Prisma Jurídico, vol. 6. São Paulo, p. 278).

${ }^{362}$ A Cooperação Penal Internacional, latu sensu, não é uma descoberta recente. Os primeiros aportes clássicos ao tema encontram-se incidentalmente em Bartolo e, de forma mais precisa, na Escola Holandesa, na obra de Grocio e seus seguidores Puffendorf e Wolff. Nos recorda João Marcello de Araújo Júnior que o primeiro caso histórico consta do tratado de paz celebrado entre Ramsés II e Hatussilli, rei dos Hititas, em 1280 a.C., e que este tratado é considerado o mais antigo da humanidade (CERVINI, Raúl; TAVARES, Juarez. Princípios de Cooperação Judicial Penal Internacional no Protocolo do Mercosul. São Paulo: RT, 2000, p. 44).

363 A efetiva repressão à criminalidade internacional crescente, tal como verificada ao longo do século XX, demonstra que os mecanismos até então utilizados no âmbito do Direito Penal não mais se apresentam como eficientes. Surge, assim, a coordenação entre Estados por meio da cooperação jurídica internacional, em que se
} 
A cooperação jurídica internacional ${ }^{364-365}$ consiste em um meio de prover assistência para que se conheçam e se impulsionem atos processuais de outra jurisdição, bem como para constituir ou assegurar, validamente, para o Estado requerente, meio de prova no Estado requerido. Significa a colaboração entre os Estados-nação, para que coordenem suas competências e realizem ações que somente poderiam ser praticadas sob a jurisdição de um deles $^{366}$.

O sucesso da utilização da entrega vigiada, especialmente a de aplicação internacional, depende da eficiente comunicação entre as polícias (estadual, federal e internacional) ${ }^{367}$. Do contrário, ausente tal comunicação, a não-atuação dos agentes pode

busca desassociar esse ramo do Direito da noção de soberania do Estado-nação moderno (DELMAS-MARTY, Mireille. Três Desafios para um Direito Mundial. Rio de Janeiro: Lumen Juris, 2003. p. 114).

${ }^{364}$ Segundo o Ministério da Justiça a cooperação jurídica internacional é a interação entre os Estados com o objetivo de dar eficácia extraterritorial a medidas processuais provenientes de outro Estado (Disponível em: <http://www.mj.gov.br>. Acesso em: 01.03.2010).

365 Definida, em termos gerais, como uma das variedades da Entre-ajuda Penal Internacional, a cooperação jurídica internacional se concretiza quando o aparato judicial de um Estado, que não tem poder de império senão dentro de seu território, recorre ao auxílio, à assistência que lhe podem prestar outros Estados, por meio de suas atividades jurisdicionais (MOUSO, Paulo. Cooperación judicial inter-etática. Revista Colombiana de Derecho Processal, ano III, vol. 2, Bogotá, 1990, p. 31). Para Raúl Cervini: "A cooperação judicial penal internacional pode ser esquematizada funcionalmente como um conjunto de atividades processuais (cuja projeção não se esgota nas mais simples formas), regulares (normais), concretas e de diverso nível, cumpridas por órgãos jurisdicionais (competentes) em material penal, pertencentes a distintos Estados Soberanos, que converge (funcional e necessariamente) em nível internacional, na realização de um mesmo fim, que não é senão o desenvolvimento (preparação e consecução) de um processo (principal) da mesma natureza (penal), dentro de um estrito marco de garantias, conforme o diverso grau e projeção intrínseco do auxílio requerido" (CERVINI, Raúl. La cooperación judicial penal internacional, concepto y proyección. Curso de cooperación penal.p.6).

${ }_{366}$ PROST, K. Breaking Down the Barriers: International Cooperation in Combating Transnational Crime.

${ }^{367}$ Dentre as conhecidas polícias criminais internacionais podemos citar: 1) Interpol: A Interpol (Organização Internacional de Polícia Criminal - OICP ou International Criminal Police Organization - ICPO), com sede em Lyon, França, é a maior organização internacional policial com 186 Países-membros, criada em 1923, em Viena, Austrália, para facilitar a cooperação e integração policial e trabalha provendo assistência e suporte a todas as organizações, autoridades e serviços cuja missão seja prevenir ou combater o crime internacional. A Interpol ajuda a cooperação policial internacional em qualquer lugar mesmo que não haja relações diplomáticas entre os países envolvidos. $O$ ato de constituição da Interpol proíbe qualquer intervenção ou atividade de caráter político, militar, religioso ou racial. A Interpol Brasil é integrada por diversos órgãos administrativos, dentre os quais o importante Setor de Difusões (e de Procuradores Internacionais) ao qual compete elaborar, processar e disseminar as difusões internacionais da Organização Internacional de Policia Criminal - OIPC (Interpol), localizar foragidos visando à sua captura e pessoas desaparecidas com fins humanitários; localizar foragidos da justiça nacional no exterior, a fim de executar a sua recondução ao território brasileiro, localizar foragidos da justiça internacional no território brasileiro, visando dar cumprimento aos mandados de prisão expedidos pelo Supremo Tribunal Federal; requerer pedido de prisão preventiva de nacionais no exterior por intermédio dos meios de comunicação da OIPC (Interpol) etc. Outro sistema da Interpol, o sistema de informações 24 horas por dia, 7 (sete) dias por semana (I-24/7), tem hoje mais de 600 milhões de registros. Entre as ferramentas oferecidas pelo I24/7 encontra-se o serviço de alertas conhecidos como "difusões internacionais". A ferramenta usa as cores vermelho, preto, azul, verde, amarelo e laranja para indicar o crime cometido por determinado infrator e a existência de mandado de prisão em aberto para ele. Em 2005 foi criada uma difusão especial pela Interpol e pelo 
levar à impunidade de muitos carregadores de cargas ilícitas, sem qualquer utilidade à segurança pública.

\section{Identificam-se três níveis na cooperação jurídica internacional ${ }^{368}$ : o} primeiro, referente aos atos de mero impulso processual, tais como a citação, a intimação e a

Conselho de Segurança das Nações Unidas para localizar especificamente pessoas ligadas com a rede Al Qaeda e os Talibãs, conforme a própria OIPC divulgou para a imprensa por ocasião da $75^{\circ}$ Assembléia Geral da Interpol, que ocorreu no Forte de Copacabana, no Rio de Janeiro; 2) Cepol e Europol: Na Europa há a integração entre países componentes da Comunidade Europeia, convidados e aderentes, pela formação policial (Cepol) e pela estrutura de investigação conjunta (Europol). A Cepol (The European Police College), criada no ano de 2000, teve sede temporária na Dinamarca e a definitiva na Inglaterra, ministrando curso para expertos, policiais seniores, na língua oficial inglesa. A European Law Enforcement ou Serviço Europeu de Polícia (Europol), criada em 07/02/1992, estabelecida a partir de 1994, em Haia, Holanda, é a organização da União Europeia para reforçar a aplicação da lei e que atua mediante um trabalho de inteligência criminal, a fim de prevenir e combater as formas sérias e graves do crime organizado internacional e do terrorismo. A Europol não tem poderes executivos como os serviços de polícia dos Estados-Membros, nem pode interpelar indivíduos e realizar busca domiciliar, contudo, está encarregada de facilitar o intercâmbio de informações, analisar essas informações e coordenar as operações entre os Estados-Membros. 3) Eurojust: A União Europeia instituiu o Eurojust - European Union's Judicial Cooperation Unit, composta por integrantes dos seus Estados-Membros, entre eles: Áustria, Bélgica, Bulgária, Dinamarca, Finlândia, França, Alemanha, Grécia, Irlanda, Itália, Luxemburgo, Holanda, Portugal, Espanha, Suécia, Reino Unido, Republica Tcheca, Estônia, Chipre, Lituânia, Letônia, Hungria, Malta, Polônia, Romênia, Eslovênia, Eslováquia etc. A Eurojust é instituída enquanto órgão da União dotada de personalidade jurídica. Cada Estado-Membro nomeia um membro nacional da Eurojust que tem a qualidade de procurador, juiz ou oficial de policia (este último deve ter competências equivalentes às de juiz ou de procurador). Os membros nacionais supracitados são sujeitos ao direito nacional do estado-Membro que os nomeou. Além disso, cada qual fixa a duração do mandato, bem como a natureza das competências judiciárias conferidas ao seu representante nacional. A Eurojust é competente no que diz respeito às investigações e aos procedimentos penais (que envolvam pelo menos dois Estados-membros) relativos à criminalidade grave para promover a coordenação entre as autoridades competentes de vários Estados-Membros e facilitar a aplicação do auxílio judiciário mútuo internacional e a execução dos pedidos de extradição. A competência da Eurojust trata de crimes da esfera de atuação da Europol, como terrorismo, tráfico de drogas, de seres humanos, falsificação de moeda, lavagem de dinheiro etc., e pode desempenhar as suas funções tanto por intermédio de um ou de vários membros nacionais como colegialmente, podendo solicitar às autoridades dos Estados-Membros que dêem início a uma investigação ou instaurem um procedimento penal e criem uma equipe de investigação conjunta; 4) Rede Judiciária Europeia: A Rede Judiciária Europeia tem entre as suas atribuições a facilitação do estabelecimento de contatos adequados entre os pontos de contato dos diferentes Estados-Membros; organizar reuniões periódicas dos representantes e proporcionar, permanentemente, uma série de informações de base atualizadas, em particular por meio de uma rede de telecomunicações adequada. (GOMES, Rodrigo Carneiro. O crime Organizado na visão da Convenção de Palermo, $2^{\mathrm{a}}$ edição. Belo Horizonte: editora Del Rey, 2009, p. 259/265).

${ }^{368}$ Há quem defina os três níveis de outra forma: 1) o da colaboração no cumprimento de atos instrutórios e cautelares necessários ao desenvolvimento de determinado processo penal; 2) o que se refere à colaboração na localização, detenção e devolução do acusado da prática de determinado delito, ou daquele já considerado culpado pela prática, para que responda a processo ou que cumpra a sanção penal - o que se dá por meio de extradição; 3) o que cuida da colaboração na produção de efeitos, no território de um Estado, originários de uma sentença penal condenatória, havido em outro (RABELO, Carolina Glayder. A cooperação jurídica internacional e o crime organizado transnacional. Prisma Jurídico, vol. 6. São Paulo, p. 278). Dessa forma, criaram-se formas de colaboração entre os Estados, desejosos de levar, a bom termo, a tarefa de solucionar os conflitos de natureza penal, isto é, em suma, mecanismos de cooperação internacional em matéria criminal, de auxílio entre os órgãos competentes de dois ou mais Estados Soberanos, por meio dos quais puderam ser realizados atos indispensáveis ao esclarecimentos de ilícitos criminais, de repartição do produto da ação criminosa, de captura e devolução do 
inquirição de testemunhas; o segundo, compreendendo atos acautelatórios que venham causar potencial gravame patrimonial irreparável a uma pessoa natural ou jurídica; o terceiro, abarcando atos de restrição à liberdade daqueles que venham a ser objeto do pedido de cooperação, como é o caso da expulsão, da deportação e da extradição ${ }^{369}$. Esses graus de assistência correspondem ao objeto ${ }^{370}$ do pedido de cooperação, ditando os requisitos e os procedimentos de natureza instrumental, assim como as condições necessárias para permitir a cooperação jurídica internacional.

A cooperação jurídica internacional ${ }^{371}$ pode se basear em tratado ou em pedido de reciprocidade, segundo o qual os Estados poderão cooperar com outros ${ }^{372}$, sem prévio tratado internacional, mas por via de compromissos mutuamente assumidos para um determinado caso concreto ${ }^{373}$.

criminoso prófugo e de execução no território de um Estado, da sentença penal emanada do Poder Judiciário de outro.

${ }^{369}$ CERVINI, Raúl; TAVARES, Juarez. Princípios de Cooperação Judicial Penal Internacional no Protocolo do MERCOSUL. São Paulo: RT, 2000, p. 68.

$370 \mathrm{O}$ objeto da cooperação jurídica se torna efetivo quando o aparato judicial de uma nação se mostra insuficiente à solução da controvérsia, fazendo com que se necessite recorrer ao auxílio de outras nações e suas atividades jurisdicionais. Traduz-se, na verdade, como política de ajuda mútua no âmbito internacional. Segundo Fernando Martín Diz, os objetivos da cooperação jurídica internacional podem ser observados à luz das demais matérias consideradas objeto de cooperação, quando aponta: “(...) en este proceso de establecer paulatinamente lazos de unión entre las autoridades policiales y judiciales de los Estados miembros de la Unión Europea, se vislumbra como la idea preferente es la consolidación ininterrupta del spacio de libertad, seguridad y justicia común mediante la mecanización de diversos elementos que impliquen actuaciones conjuntas entre los órganos competentes de los diferentes países y que a su vez sean aptos de cohonestarse, cada uno de estos elementos, entre sí mismos (...) (los objetivos de la Unidad Eurojust) se centran en fomentar y mejorar la coordinación entre la autoridades competentes de los Estados miembros en las investigaciones y actuaciones judiciales que les afecten; mejorar en segundo lugar la cooperación entre autoridades, en particular facilitando la ejecución de la asistencia judicial internacional y de las solicitudes de extradición, y cerrando el carácter excesivamente abstracto y generalista de sus objetivos - que se aproximan claramente al terreno de una simple declaración de intenciones, nada nueva ni original respecto a lo ya conocido -, el apoyo en general a las autoridades competentes para dar mayor eficacia a sus investigaciones y actuaciones"(DIZ, F. M. Instrumentos Jurídicos de cooperación judicial penal en La Unión Europea. In: BELMONTE, C.P; MELGARÉ, P. (Coord.). O direito na sociedade contemporânea: estudos em homenagem ao Ministro José Néri da Silveira. $1^{a}$ edição. Rio de Janeiro: Forense, 2005. p. 268/276.

371 Dos mecanismos desse tipo de cooperação, alguns merecem destaques: as homologações de sentenças estrangeiras, as cartas rogatórias, os pedidos de assistência jurídica, e a transferência de apenados.

${ }^{372}$ Em razão de os Estados não poderem exercer, diretamente, suas pretensões fora de seus limites territoriais, devido à soberania, cabe-lhe formular pedido de cooperação, com base em critérios estabelecidos, verificando-se, ainda, a exequibilidade da pretensão jurídica havida no pedido de cooperação.

${ }^{373}$ Ressalta-se que esse auxílio fundamenta-se na cortesia internacional entre Estados, que pressupõe a discricionariedade de recepção do pedido por parte do Estado requerido. Não obstante, a cooperação jurídica internacional deve ser vista como uma obrigação assumida constitucionalmente pelo Brasil em face dos demais Estados, tendo em vista os termos do art. $4^{\circ}$, inciso IX, da Constituição Federal. 
No Brasil, em conformidade com o artigo 11, inciso III, do Decreto $\mathrm{n}^{\circ}$ 5.834, de 06/07/2006, compete ao Departamento de Recuperação de Ativos e Cooperação Jurídica Internacional - DRCI ${ }^{374}$ - negociar acordos e coordenar a execução da cooperação jurídica internacional. Portaria Conjunta do Ministério da Justiça, da Procuradoria Geral da República e da Advocacia Geral da União, publicada no DOU de 28.10.05, passou a disciplinar o tema, dispondo sobre a tramitação de pedidos de cooperação jurídica internacional em matéria penal entre as instituições mencionadas ${ }^{375}$.

Neste contexto de cooperação internacional ${ }^{376}$, a entrega vigiada tem se tornado, pouco a pouco, um eficiente instrumento no combate ao crime organizado. Conquanto novo e em diversos países sem forma definida de utilização e procedimento, a ideia da possibilidade de introdução de um mecanismo de cooperação internacional contra a criminalidade estruturada, como a entrega vigiada, torna a discussão sobre o assunto extremamente significante.

\footnotetext{
${ }^{374}$ Para Rodrigo Carneiro Gomes: "É fato que o DRCI atua como Autoridade Central para tramitação de pedidos de cooperação jurídica internacional, contudo, é duvidosa a competência traçada por ato normativo infralegal para atribuir a instrução e manifestação "na execução da cooperação jurídica internacional ativa e passiva, inclusive cartas rogatórias", especialmente quando se trate de matéria penal que acarrete a realização de diligências, para fins de prova criminal, seja para instrução de procedimentos preliminares de investigação da competência de autoridades policiais brasileiras (realizadas no exterior) ou de quem de direito, ou para que a autoridade policial brasileira coopere na realização de atos para fins de instrução de procedimentos estrangeiros" (GOMES, Rodrigo Carneiro. O crime Organizado na visão da Convenção de Palermo, $2^{\mathrm{a}}$ edição. Belo Horizonte: Editora Del Rey, 2009, p. 250).

${ }^{375}$ Com o advento da Portaria 1.876, de 27.10.2006, dispondo sobre a tramitação de pedidos de cooperação jurídica internacional em matéria penal no âmbito do Ministério da Justiça, ficou claro que os pedidos de cooperação jurídica internacional passiva em matéria penal (recebidos pelo Brasil) serão encaminhados pelo DRCI ao DPF (Departamento da Polícia Federal), enquanto que os pedidos de cooperação jurídica internacional ativa, de atribuição do DPF, serão enviados ao DRCI.

376 A cooperação jurídica internacional está prevista na Convenção da ONU contra o Tráfico Ilícito de Entorpecentes e Substâncias Psicotrópicas (Viena, 1988, artigo $6^{\circ}$ e $7^{\circ}$ ), na Lei $n^{\circ} 11.343$, de 23.08.2006 (lei sobre drogas artigo 65), no Acordo de Extradição entre os Estados-partes do Mercosul (trata especificamente da cooperação jurídica internacional e foi concluído no Rio de Janeiro em 10.12.1998, promulgado por meio do Decreto Legislativo n. 605, de 11.09.2003, entrando em vigor internacionalmente e no Brasil em 01.01.2004, em decorrência do Tratado de Assunção, que constituiu o Mercado Comum do Sul (Mercosul), assinado em 26.03.1991), na Convenção da ONU contra o Crime Organizado Transnacional (Palermo, 2000, artigos 16 a 19), na Convenção da ONU contra a Corrupção (Mérida, 2003, artigo 44 e 46), na Convenção do Conselho da Europa acerca da Lavagem, Rastreamento e Confisco dos Produtos do Crime (Estrasburgo, 1990, artigos $7^{\circ}$ a 35) e na Convenção do Conselho da Europa relativa à Lavagem, Apreensão, Perda e Confisco das Vantagens do crime e ao financiamento ao terrorismo (Varsóvia, 2005, artigos 15 a 45), bem como na Lei no 9.613, de 03.03.1998 (Lei de Lavagem de Dinheiro, artigo $8^{\circ}$ ) e no Regulamento Modelo CICAD/OEA (artigo 20).
} 
De fato, esse meio de investigação foi sugerido, inicialmente, como forma de cooperação internacional no combate ao tráfico internacional de drogas, pelo qual países diferentes, com base em acordos e convenções internacionais, podem controlar a entrada, saída e o trânsito de drogas de um país para outro. Significa dizer que a entrega vigiada floresceu como um instrumento a ser utilizado de forma cooperada entre países na Convenção de Viena ${ }^{377}$, se estendendo para outros tratados ${ }^{378}$ e, posteriormente, passou a ser prevista sua utilização no âmbito interno de diversos Estados membros.

Salienta Delgado ${ }^{379}$ que essa técnica de investigação supõe a existência de uma verdadeira cooperação internacional ${ }^{380}$ na repressão ao tráfico de drogas, já que a entrega vigiada: "implica, pelo menos, na intervenção de dois Estados, um pelo qual circula a remessa

377 A entrega vigiada é um procedimento previsto e recomendado, por primeiro, pelas Nações Unidas, na Convenção de Viena de 1988. De se lembrar o quanto disposto no artigo 11 de referida Convenção: Se os princípios fundamentais dos respectivos ordenamentos jurídicos internos o permitirem, as Partes adotarão as medidas necessárias, dentro de suas possibilidades, para que se possa recorrer, de forma adequada, no plano internacional, à entrega vigiada, com base nos acordos e ajustes mutuamente negociados, com a finalidade de descobrir as pessoas implicadas em delitos estabelecidos de acordo com o parágrafo 1 do Artigo 3 e de encetar ações legais contra estes. Vide capítulo 2 deste trabalho para conferir o surgimento da entrega e sua previsão nos diversos tratados internacionais.

${ }^{378}$ Lembra Carneiro que: "Na Convenção de Palermo, além da entrega vigiada, constante no artigo 20, dentre as técnicas especiais de investigação, outros instrumentos de cooperação estão previstos, mediante a celebração de acordos ou protocolos bilaterais ou multilaterais, tais como: a transferência de pessoas presas para cumprimento de pena em outro país (artigo 17); o estabelecimento de órgãos mistos de investigação, respeitada a soberania dos países (artigo 19); a transferência mútua de processos penais de delitos da convenção, quando necessária para a boa administração da justiça e envolvidas várias jurisdições, para centralizar a instrução dos processos (artigo 21); unificação de antecedentes penais (artigo 22). É cabível a transferência de preso de um país para outro para sua identificação, testemunho ou ajuda na obtenção de provas em investigação em sede de delito previsto na convenção, desde que haja consentimento do preso e das autoridades competentes (artigo 18, item 10). A testemunha, perito ou outra pessoa que, a pedido do país requerente, aceite depor num processo ou colaborar numa investigação, em processos ou outros atos judiciais no território do Estado-Parte requerente, não se sujeitará a processo ou restrições à sua liberdade neste território, por atos anteriores à sua partida do território requerido" (GOMES, Rodrigo Carneiro. O crime Organizado na visão da Convenção de Palermo, $2^{\mathrm{a}}$ edição. Belo Horizonte: editora Del Rey, 2009, p. 252).

${ }^{379}$ MARTín, Joaquín Delgado. El arrepentido, el agente encubierto y la entrega vigilada, $1^{\text {a }}$ edição, Editora Ad Hoc, Buenos Aires, p. 108. Tradução livre do texto original: "implica, por lo menos, la intervención de dos Estados, uno por el cual circula la remesa de estupefacientes, y otro que será de destino; por ello, el ordenamiento de ambos países debe contemplar la posibilidad de aplicar la entrega controlada, para que la remesa que sale de un país, sea secuestrada por el país de destino, juntamente con la detención de los destinatarios y participes de dicho envío"

${ }^{380}$ Rodrigo Carneiro Gomes conclui que: "Só com essa efetiva cooperação internacional e aperfeiçoamento dos instrumentos de combate ao crime organizado previstos na Convenção de Palermo, que podem ser desencorajadas ações da criminalidade organizada, ou seja, da empresa do crime. Portanto, com o emprego uniforme, coeso e efetivo dos mecanismos explanados é que haverão de se concretizar os postulados dessa estreita cooperação, o que ora se preconiza como via de solução, a despeito de se reconhecer o desequilíbrio de forças entre o crime e as estruturas oficiais de repressão, quadro que se verifica não apenas no nosso País, mas no contexto da grande maioria das nações" (GOMES, Rodrigo Carneiro. O crime Organizado na visão da Convenção de Palermo, $2^{\mathrm{a}}$ edição. Belo Horizonte: Editora Del Rey, 2009, p. 278). 
de entorpecentes e outro que será o destino; por isso, o ordenamento de ambos países devem contemplar a possibilidade de aplicar a entrega vigiada, para que a remessa que saia de um país, seja sequestrada pelo país de destino, juntamente com a detenção dos destinatários e participantes do dito envio".

Para o autor, sem a cooperação entre países, será inaplicável a entrega controlada: "se o país de destino não perseguir penalmente os destinatários da remessa, não tem sentido que os entorpecentes saiam do país de origem ${ }^{381}$,.

No caso, a entrega vigiada, quando utilizada como instrumento extraordinário de obtenção de prova envolvendo mais de um país, carece, obrigatoriamente, da cooperação internacional $^{382}$, por meio de assinatura de tratado multilateral entre os Estados envolvidos. Isto porque a vigia das remessas ilícitas, sem a sua interceptação prévia, requer a autorização dos diversos países ${ }^{383}$ que serão rota de passagem das mercadorias ilícitas, até que alcancem seu destino, desmantelando a organização como um todo. Em razão da soberania, a autoridade de um Estado não poderá perseguir a remessa ilícita quando esta adentrar as fronteiras do país vizinho, impondo-se, pois, a adoção da cooperação.

${ }^{381}$ MARTíN, Joaquín Delgado. El arrepentido, el agente encubierto y la entrega vigilada, $1^{\text {a }}$ edição, Editora Ad Hoc, Buenos Aires, p. 108. Tradução livre do texto original: "ya que si el país de destino no persigue penalmente a los destinatarios de la remesa, no tiene sentido que los estupefacientes salgan del país de origen".

${ }^{382}$ Da Cooperação Internacional - previsão na Convenção de Viena: Art. 65 - De conformidade com os princípios da não-intervenção em assuntos internos, da igualdade jurídica e do respeito à integridade territorial dos Estados e às leis e aos regulamentos nacionais em vigor, e observado o espírito das Convenções das Nações Unidas e outros instrumentos jurídicos internacionais relacionados à questão das drogas, de que o Brasil é parte, o governo brasileiro prestará, quando solicitado, cooperação a outros países e organismos internacionais e, quando necessário, deles solicitará a colaboração, nas áreas de:

I - intercâmbio de informações sobre legislações, experiências, projetos e programas voltados para atividades de prevenção do uso indevido, de atenção e de reinserção social de usuários e dependentes de drogas;

II - intercâmbio de inteligência policial sobre produção e tráfico de drogas e delitos conexos, em especial o tráfico de armas, a lavagem de dinheiro e o desvio de precursores químicos;

III - intercâmbio de informações policiais e judiciais sobre produtores e traficantes de drogas e seus precursores químicos.

${ }^{383}$ No julgamento do HC 85588, relator Ministro Marco Aurélio, $1^{\text {a }}$ Turma do STF, de 15.12.2006, ficou consignado que a cooperação internacional no combate ao crime organizado não dispensa a submissão de autoridade judicial estrangeira ao STJ (com o advento da EC 45/2004): "Crime - Cooperação Internacional Combate - Diligências - Território Nacional - Meio. A prática de atos decorrentes de pronunciamento de autoridade judicial estrangeira, em território nacional, objetivando o combate ao crime, pressupõe carta rogatória a ser submetida, sob o ângulo da execução, ao crivo do Superior Tribunal de Justiça, não cabendo potencializar a cooperação internacional a ponto de colocar em segundo plano formalidade essencial à valia dos atos a serem realizados. 


\subsubsection{Harmonização legislativa}

Imprescindível a adoção de uma legislação harmônica ${ }^{384}$ entre os diversos diplomas $^{385}$, justamente para implementar a cooperação internacional de maneira eficaz. A harmonização legislativa significa uma decorrência lógica da necessidade de colaboração internacional entre países no manejo de instrumentos de cooperação, como a entrega vigiada.

Em verdade, tais instrumentos de obtenção de provas, na maioria das vezes, só alcançarão algum tipo de resultado positivo se utilizados de forma conexa e convergente pelos diversos países interessados na operação, quando existentes normas em comum que propiciem a similitude de linguagem jurídica.

Dessa forma, os Estados que possuírem expressa previsão legislativa acerca da possibilidade de utilização da entrega vigiada em seus diplomas internos ${ }^{386} \mathrm{e}$, desde

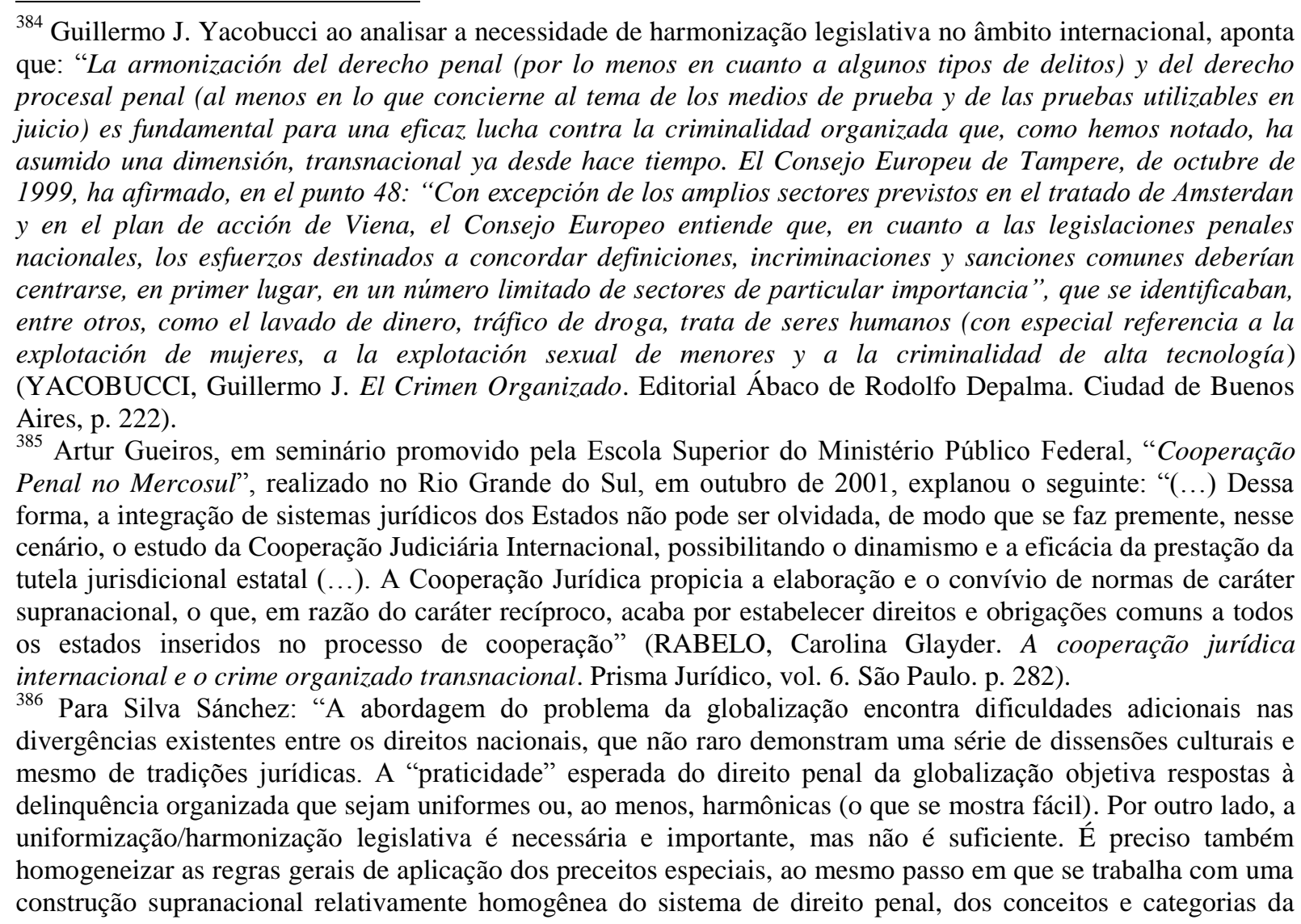


que tais normas não sejam incompatíveis entre si, desfrutarão certamente de maiores facilidades na prática de suas operações. Cada vez mais os Estados deverão procurar adotar diplomas que disponham acerca do mesmo instituto de forma harmônica e compatível, evitando que as lacunas legislativas impeçam o rápido compartilhamento de ações intercaladas com vista a um objetivo comum. O direito considerado isoladamente não tem condições de combater a criminalidade organizada, que possui contornos transnacionais.

Tome-se, por exemplo, a ocorrência de uma entrega vigiada de drogas ou outro produto ilícito entre três países fronteiriços, sendo que a substância entorpecente tenha de sair do primeiro país, atravessar pelo segundo até chegar ao terceiro, como destino final. Mesmo havendo acordo internacional entre os países - como sendo signatários da Convenção de Viena de 1988 -, que prevê a possibilidade do emprego da entrega vigiada, se não houver previsão legislativa interna harmônica entre eles, possivelmente a convenção não bastará, já que esta apenas traz a figura e sua possibilidade de adoção entre países, mas não menciona quem seria a autoridade competente para autorizar a passagem entre países, como seria o procedimento de atuação conjunta entre os países, quem seria o responsável pela eventual interceptação, dentre outras tantas questões técnicas que somente a legislação poderia prever.

Portanto, a simples celebração de acordos internacionais prevendo a técnica de investigação, muitas vezes, pode não facilitar em nada a sua efetiva adoção, quando não houver previsão normativa interna no país que especifique o procedimento e maneira de

teoria jurídica do delito, assim como dos princípios e garantias político-criminais fundamentais. nem mesmo os tratados de unificação setorial do direito penal garantem a homogeneidade das respostas, que podem se dar diferentemente no âmbito jurisdicional. Ademais, a atribuição da jurisdição e da própria produção legislativa a instâncias supranacionais implica, ao menos por enquanto, em um sério problema de legitimação democrática (como verificado nos processos de integração e, com muito maior seriedade, nos outros tipos de instâncias supranacionais). Portanto, o mais provável será a adoção de tratados de uniformização (tanto na parte geral quanto especial do direito penal), acompanhados de esforços para garantir "de fato" (mediante encontros, seminários, etc) suas aplicações da forma mais homogênea possível. Ademais, é relevante distinguir-se que uma coerência penal com traços teleológico-valorativos, embora possa ser supranacional (independentemente dos ordenamentos jurídicos nacionais), não pode deixar de ser condicionada pelas variações espaço-temporais. As finalidades político-criminais do direito penal, as suas categorias e conceitos dogmáticos não são os mesmos, por exemplo, no mundo ocidental, no mundo islâmico e no extremo oriente. Esses próprios mundos não são estáticos, mas se modificam com o passar do tempo. Assim, embora se possa falar de uma criminalidade organizada transnacional e globalizada, e de uma tendência à harmonização e homogeneização legislativa, cumpre seja determinado o espaço a ser resguardado (ou não) para as especificidades penais dos diferentes pontos do globo. Possivelmente ainda demore bastante tempo para que um direito penal internacional surja (e se mantenha) com poderio e legitimidade suficientes para atuar no controle do crime organizado" (SILVA SANCHÉZ, Jesús-María. Op. cit. p. 152-153). 
sua utilização (exceto se o acordo ou pedido de reciprocidade, para o caso concreto, estabelecer as regras de atuação, independentemente da legislação interna).

Tal constatação encontra-se presente na lição de Guillermo J. Yacobucci ${ }^{387}$ : “em matéria de remessas controladas, a harmonização das legislações nacionais se propõe com um objetivo prioritário, uma vez que, como temos assinalado repetidamente, os mercados ilícitos manejados pelas organizações criminosas estão constituídos, principalmente, por coisa móveis, destinadas a ser transferidas de um país "produtor" a um "consumidor", através do território de países de trânsito. Uma lacuna ou uma discordância na legislação de um ou mais de tais países determinaria vazios na ação de contraste com a impossibilidade de seguir o trânsito de tráficos ilegais".

A harmonização legislativa segue, regra geral, dois caminhos. Pode haver a adoção, no direito interno dos países, de normas similares tratando do mesmo assunto ou pode haver, de outro modo, a adoção de "normas supranacionais",388, como ocorre no caso da União Europeia.

${ }^{387}$ YACOBUCCI, Guillermo J. El Crimen Organizado. Editorial Ábaco de Rodolfo Depalma. Ciudad de Buenos Aires, p. 222. Tradução livre do original: "en materia de "consignas controladas", la armonización de las legislaciones nacionales se propone como un objetivo prioritario, ya que, como hemos señalado repetidamente, los mercados ilícitos manejados por las organizaciones criminales están constituidos, principalmente, por "cosas muebles" destinadas a ser transferidas de un país "productor" a uno "consumidor", a través del territorio de países de "tránsito". Una laguna o una discordancia en la legislación de uno o más de tales países determinaría "vacios" en la acción de contraste con la imposibilidad de infiltrar grupos criminales y de seguir el desarrollo de los tráficos ilegales".

388 Jurisdição supranacional pode ser entendida quando a aplicação do direito se dá além das regras internas, ou seja, quando Estados Membros permitem que um órgão, não pertencente ao seu direito nacional possa atuar, de forma competente e legítima, em questões internacionais. Em outras palavras, a jurisdição supranacional confere poderes de atuação a um órgão situado acima das normas Estatais dos estados membros. A dificuldade pode ser percebida já de início pela conceituação de órgão jurisdicional supranacional, uma vez que os Estados Membros teriam que, supostamente, abrir mão de sua autonomia, envolvendo, no mais das vezes, a complexa questão de sua soberania para sujeitar-se a um órgão fora e acima de seu poder direto. A ideia de supranacionalidade surge porque os conceitos clássicos de Estado, nação e soberania não mais encontram condições de aplicação estrita e efetiva no mundo contemporâneo sendo necessário, nas relações existentes na atualidade e, em especial, nos casos em que houver a intervenção da justiça, integrar relativização e flexibilização a tais conceituações. Para Sandro Brescovit Trotta: "conceituar "soberania", hoje, é tarefa das mais árduas, pois não tem mais aplicação as respostas clássicas à medida que a globalização econômica alterou o centro e o vértice do sistema social. De fato, a soberania estatal tem sido questionada, porquanto se vislumbra uma tendência de interdependência crescente entre os Estados e sua união em organizações de natureza supranacional, que podem limitar sua real capacidade de autodeterminação. Daí a dificuldade de se discutir a questão do exame de órgãos de atuação supranacional, sem que haja a preocupação em relacioná-los à soberania estatal, a fim de concluir se há ou não afronta a este atributo do Estado, motivo pelo qual diversos Estados Membros se recusam a admitir a jurisdição de um órgão como este, que teria suposta ingerência em assuntos internos, afrontando sua soberania (TROTTA, Sandro 
Todavia, este segundo método encontra maiores resistências, porquanto se discute que normas supranacionais ${ }^{389}$ (embora tragam homogenia) podem afrontar a soberania dos Estados.

Assim, extremamente pertinente o imediato estudo e análise da legislação sobre a entrega vigiada, para que haja regulamentação sobre o assunto, com o fito de iniciar sua aplicação entre os diversos países que ratificaram as Convenções que prevêem tal técnica de investigação. A partir da adoção de uma legislação harmoniosa entre os Estados acerca do instituto, sua aplicabilidade restará facilitada, com contornos legítimos.

Brescovit. As Jurisdições Penais Supranacionais e os Instrumentos de Proteção aos Direitos humanos. Dissertação de Mestrado, PUC Rio Grande do Sul, 2006).

${ }^{389}$ Expõe Francis Rafael Beck, em relação a este segundo modelo que: "O caráter transnacional (global) dos problemas exige que também sejam globais as suas soluções, o que pressupõe uma tendência de harmonização e uniformização legislativa. A inexistência de organismos internacionais que disponham do jus persequendi e do jus puniendi, que possam promulgar normas penais e processuais de caráter supranacional dificulta sobremaneira o controle da criminalidade organizada (BECK, Francis Rafael. Perspectivas de controle ao crime organizado e crítica à flexibilização das garantias. IBCCRIM, São Paulo, 2004, p. 152). Para Silva Sánchez "embora necessária e importante, essa tendência não resta suficiente se se deixar de trabalhar simultaneamente com uma construção supranacional relativamente homogênea do sistema do direito penal e dos conceitos e categorias da teoria jurídica do delito" (SILVA SANCHÉZ, Jesús-María. Bases de una dogmática jurídico-penal supranacional. Revista Brasileira de Ciências Criminais, São Paulo: RT, v. 3, n.12, out-dez, 1995, p. 34). 


\section{CONCLUSÕES}

A evolução da criminalidade organizada, notadamente ao longo das últimas décadas, derrubou fronteiras e tornou-se um fenômeno transnacional. $\mathrm{O}$ crime organizado se revela como uma ameaça para a estabilidade e segurança das sociedades ao enfraquecer as instituições e os valores da democracia, da ética, da justiça e ao comprometer o desenvolvimento sustentável do Estado Democrático de Direito.

Justamente por causa desse novo cenário mundial, aliado à preocupação com o enfrentamento dessa modalidade de crime e percepção de que os meios ordinários de investigação são ineficazes para fazer frente ao avanço das operações desenvolvidas pelas organizações criminosas, os mecanismos internacionais de cooperação e combate ao crime organizado passaram a conceber novos meios de investigação, como a entrega vigiada.

Enquadrada na modalidade de vigilância e monitoramento, a entrega vigiada representa, em síntese, uma técnica, método ou meio de investigação consistente em permitir que remessas ilícitas ou suspeitas (sejam de drogas, substâncias entorpecentes, armas ou outros objetos ilícitos da atividade criminosa) circulem no interior de um Estado ou saiam do território de mais de um Estado, os atravessem ou neles entrem, de forma monitorada, com o conhecimento e sob o controle das autoridades competentes, para melhor atingir o objetivo de identificação de outros agentes participantes envolvidos na sua prática, bem como desvendar seu modus operandi. Além de meio de investigação, a entrega vigiada pode ser vista como um instrumento de cooperação internacional no combate ao crime organizado.

No Brasil não existe previsão legal da entrega vigiada no ordenamento jurídico interno. A figura prevista na Lei de Drogas guarda muito mais semelhança com a figura da ação controlada, de acordo com as características dos dois institutos. Em razão da elevada similitude, a entrega vigiada pode ser considerada espécie do gênero ação controlada, exatamente no ponto em que a não intervenção sob controle da autoridade competente recaia sobre o trânsito de remessas ilícitas. 
Sob certos aspectos a entrega vigiada pode ser considerada uma técnica de investigação excepcional, notadamente porque: 1) permite o monitoramento de um crime em andamento, sem a imediata intervenção; 2) deve ser utilizado para enfrentamento de crimes graves, relacionados ao crime organizado; 3) pela atipicidade do meio de obtenção de prova; 4) por afrontar direito fundamental, em certas hipóteses, principalmente na modalidade de entrega vigiada por substituição.

Se por um lado a entrega vigiada pode ser considerada um instrumento eficiente na luta contra o crime organizado, por outro - e justamente por ser um meio de investigação, em certas hipóteses com caráter excepcional - pode causar violação a direito fundamental do investigado, afrontando princípios constitucionais e processuais penais. A inviolabilidade do sigilo das comunicações e da intimidade são direitos mais visados e em constante ameaça quando da utilização da técnica investigativa.

O principal problema no emprego da entrega vigiada consiste na falta de regulamentação legislativa, possibilitando abusos e falta de critério para o controle na utilização da técnica. Não se pode olvidar o fato de que a medida, quando não controlada, permite que o agente supostamente vigilante provoque ou cometa delito, havendo, também, desvirtuamento da medida, como instituto permissivo da perpetuação da criminalidade organizada. Ademais a regulamentação torna-se imperiosa tanto em razão da internacionalização do instituto, quanto em função da necessidade de possibilitar a devida autorização ao agente vigilante, permitindo, sob o manto da lei, que deixe de intervir quando do cometimento de um delito em andamento.

Para dirimir essas questões, imperiosa a observância de requisitos mínimos quando do emprego do instituto, a saber: a) utilização para enfrentamento de crimes graves, ligados ao crime organizado; b) uso preferencialmente na fase investigação; c) existência de acordos internacionais que permitam a vigilância das remessas ilícitas entre Estados, respeitados os princípios fundamentais dos respectivos ordenamentos jurídicos internos; d) necessidade de autorização da autoridade competente, com decisão motivada e individualizada para cada remessa; e) observância da proporcionalidade no caso concreto. 
Além disso, por se tratar de técnica prevista em diversos acordos internacionais, permitindo uma atuação cooperada entre países, conveniente que haja uma harmonização legislativa na regulamentação da entrega vigiada pelos países signatários dos acordos, possibilitando maior entrosamento e eficiência no uso do meio de investigação.

Apesar das dificuldades com as quais o Estado continuará se deparando para alcançar todos os integrantes das organizações criminosas, superveniente legislação federal poderá assegurar um meio de investigação eficaz de combate ao crime organizado, por meio da entrega vigiada.

O grande desafio para o futuro consiste na adoção de uma regulamentação adequada e pertinente acerca desse meio de investigação, de modo que ao Estado seja possibilitado o efetivo exercício do jus puniendi, porém, sem se descurar do respeito e salvaguarda dos direitos e garantias individuais do investigado. A busca pela eficiência na persecução penal não pode se sobrepor às garantias individuais dos investigados, especialmente no Estado de Direito. 


\section{BIBLIOGRAFIA}

ABELLAN, Gáscon. Los hechos en el derecho - Bases Argumentales de la prueba. Madrid: Marcial, Pons, Ediciones Jurídicas y Sociales S. A., 1999.

ADRIASOLA, Gabriel. El nuevo derecho sobre toxicos e el lavado de dinero de la droga. Montevidéo: Fundacion de Cultura Universitária, 1994.

AMODIO, Ennio. Processo penale, diritto europeo e common law: dal rito inquisitório al giusto processo. Milão: Giuffrè, 2003.

ARAÚJO, Antonio Carlos C.. Comentários ao Código de Processo Civil. Rio de Janeiro, Forense, v. 4, 2000.

ARAUJO, Luiz Alberto Davi; SERRANO, Vidal. Curso de Direito Constitucional. São Paulo: Saraiva, 1998.

ARLACCHI, Pino. Tendencias de la Criminalidade Organizada y de Los Mercados Ilegales en el Mundo Actual, Poder Judicial, nº 16.

BADARÓ, Gustavo Henrique Righi Ivahy e FILHO, Antonio Magalhães Gomes. Prova e sucedâneos de prova no processo penal brasileiro. Revista Brasileira de Ciências Criminais, número 65, março-abril de 2007.

Ônus da Prova no Processo Penal. São Paulo: Revista dos Tribunais, 2003.

BATISTA JÚNIOR, Onofre Alves. Princípio Constitucional da Eficiência Administrativa. Belo Horizonte: Mandamentos, 2004.

BECCARIA, Cesare. Dos delitos e das penas. São Paulo: Martin Claret, 2001.

BECHARA, Fábio Ramazzini; MANZANO, Luís Fernando de Moraes. Crime Organizado e Terrorismo nos Estados Unidos da América In Crime Organizado - Aspectos Processuais. Antonio Scarance Fernandes; Maurício Zanoide de Moraes; José Raul Gavião de Almeida. (coords.). São Paulo: Editora Revista dos Tribunais, 2009.

BECK, Francis Rafael. Perspectivas de controle ao crime organizado e crítica à flexibilização das garantias. São Paulo: IBCCRIM, 2004. Monografias/IBCCRIM; 32.

BENTO, Ricardo Alves. Agente Infiltrado- Busca pela legitimação constitucional. In Limites Constitucionais da Investigação. Rogério Sanches Cunha, Pedro Taques, Luiz Flávio Gomes (coords.). São Paulo: Editora Revista dos Tribunais, 2009.

BORGES, Paulo César Correa. O Crime Organizado. São Paulo: UNESP, 2002. 
BROWNLIE, Ian. Principles of public internationa Law. $4^{\mathrm{a}}$ edição. Oxford: Clarendon Press, 1990.

BUERGO, Blanca Mendoza. El Derecho Penal en la Sociedad del Riego. Madrid: Civitas Ediciones, 2001.

CABADA, Gumersindo Guinarte. La Circulación o Entrega Vigilada de Drogas. Cuadernos de Política Criminal, $n^{\circ}$ 55. Universidad Complutense de Madrid. Madrid: Edersa Editoriales, 1995.

CAFFARO, Luiz Carlos. O Ministério Público e o Crime Organizado (X Congresso Nacional do Ministério Público), 1994.

CAMPOS, Pedro Franco de; BECHARA, Fábio Ramazzini e OUTROS. Direito Penal Aplicado, Parte Especial do Código Penal. São Paulo: Editora Saraiva, 2008.

CAPEZ, Fernando. Curso de Direito Penal. Legislação Penal Especial. Volume 4. São Paulo: Editora Saraiva, 2006.

CERNICCHIARO, Luiz Vicente. Organização criminosa, Direito penal especial, processo penal e direitos fundamentais: visão luso-brasileira. São Paulo: Quartier Latin, 2006.

CERVINI, Raúl. La Cooperación Judicial Penal Internacional: Concepto y Proyección, en Curso de Cooperación Penal Internacional. Carlos Alvarez Editor. Rio de Janeiro, 1994, p.6.

CERVINI, Raúl; TAVARES, Juarez. Princípios de Cooperação Judicial Penal Internacional no Protocolo do MERCOSUL. São Paulo: Revista dos Tribunais, 2000.

CHOUKR, Fauzi Hassan. Código de Processo Penal - Comentários Consolidados e Crítica Jurisprudencial. Rio de Janeiro: Editora Lumen Juris, 2005.

. Processo Penal de Emergência. Rio de Janeiro: Lumen Juris, 2001.

COGAN, Marco Antônio Pinheiro Machado e JOSÉ, Maria Jamile. Crime Organizado e Terrorismo na Espanha. In Crime Organizado - Aspectos Processuais. Antonio Scarance Fernandes; Maurício Zanoide de Moraes; José Raul Gavião de Almeida. (coords.). São Paulo: Editora Revista dos Tribunais, 2009.

COMOGLIO, Luigi Paolo. Considerazioni Inattuali Sulla Notificazione dell'impugnazione. Rivista di Diritto Processuale, anno I, nº 4. Casa Editrice Dott. Antonio Milani, 1995. . Lessico delle prove e modello accusatorio. Rivista de dirritto processualle. 1995.

CONDE, Muñoz. Derecho penal, parte especial, 9ª edição, Valencia, 1993. 
COUTINHO, Jacinto Nelson de Miranda. Efetividade do processo penal e golpe de cena: um problema às reformas processuais. In Escritos de direito e processo penal em homenagem ao professor Paulo Cláudio Tovo. Alexandre Wunderlich (coord.). Rio de Janeiro: Lumen Juris, 2002.

DAL POZZO, Antonio Araldo Ferraz. Manual Básico de Direito Processual Civil. São Paulo: Editora Oliveira Mendes, 1998.

DALLARI, Pedro de Abreu. Normas Internacionais de Direitos Humanos e a Jurisdição Interna. Revista Especial do Tribunal Regional Federal 3ª Região. São Paulo, 1997.

DELMAS-MARTY, Mireille. Três Desafios para um Direito Mundial. Rio de Janeiro: Lumen Juris, 2003.

DEZEM, Guilherme Madeira. Da prova Penal. Campinas: Editora Millennium, 2008.

DIDIER JR, Fredie e Outros. Curso de Direito Processual Civil. Editora Podivm, 2007.

DINAMARCO, Cândido Rangel. Instituições de Direito Processual Civil, vol. II. São Paulo: Malheiros, 2001.

DIZ, F. M. Instrumentos Jurídicos de cooperación judicial penal en La Unión Europea. In $O$ direito na sociedade contemporânea: estudos em homenagem ao Ministro José Néri da Silveira. Belmonte, C. P.; Melgaré, P. (Coord.). 1ª edição. Rio de Janeiro: Forense, 2005.

Dossiê Crime Organizado, Estudos Avançados da USP, plataforma Cielo. Compilação de artigos sobre o crime organizado elaborado por juristas, sociólogos, filósofos, pesquisadores, dentre outros.

DOUGLAS, William; PRADO, Geraldo. Comentários à Lei Contra o Crime Organizado, Ed. Impetus, 2001.

- Comentários à Lei Contra o Crime Organizado, organização criminosa, ação controlada, ação penal pública e privada, poderes do juiz, prisão e liberdade, sigilo bancário. Belo Horizonte: Del Rey Ltda., 1995.

EDWARDS, Carlos Enrique. El arrepentido, El agente Encubierto y La Entrega Vigilada. Modificación a la Ley de Estupefacientes. Análisis de la ley 24.424. Buenos Aires: Ad Hoc, 2001.

FASSONI, Elvio. La valutazione della prova nei processi di criminalità organizzata. In: Processo Penale e criminalità organizzata, Vittorio Grevi (org.). Roma - Bari: Laterza, 1993.

FERNANDES, Antonio Scarance. Efetividade, Processo Penal e Dignidade Humana. In Tratado Luso-Brasileiro da Dignidade Humana. São Paulo: Editora Quartier Latin, 2008. 
. Noções de Eficiência e Garantismo. In Sigilo no Processo Penal. São Paulo: Revista dos Tribunais, 2009.

. O Equilíbrio Entre a Eficiência e o Garantismo e o Crime Organizado. In Repressão Penal e o Crime Organizado, Os Novos Rumos da Política Criminal após o 11 de Setembro. Otávio Augusto de Almeida Toledo, Luís Geraldo Sant'Ana Lanfredi, Luciano Anderson de Souza e Luciano Nascimento Silva (coords.). São Paulo: Editora Quartier Latin, 2009.

O Equilíbrio Entre a Eficiência e Garantismo e o Crime Organizado. IBCCRIM, 70/233. São Paulo: RT, 2008.

. O Equilíbrio na Repressão ao Crime Organizado. In Crime Organizado Aspectos Processuais. Antonio Scarance Fernandes; Maurício Zanoide de Moraes; José Raul Gavião de Almeida. (coords.). São Paulo: Editora Revista dos Tribunais, 2009.

Tribunais, 2002.

. Processo Penal Constitucional. $3^{\text {a }}$ edição. São Paulo: Editora Revista dos . Prova e Sucedâneos da Prova no Processo Penal (Extraído do Relatório para as XX Jornadas Ibero americanas de Direito Processual Penal em Málaga, Espanha em 2006). Revista Brasileira de Ciências Criminais. Editora Revista dos Tribunais, nº 66, maio/junho de 2007.

Reflexões Sobre as Noções de Eficiência e de Garantismo no processo penal. In: Sigilo no Processo Penal. Eficiência e Garantismo. Coord. Antonio Scarance Fernandes, José Raul Gavião de Almeida e Maurício Zanoide de Moraes. Editora Revista dos Tribunais, 2008.

. Teoria Geral do Procedimento e o Procedimento no Processo Penal. São Paulo, Editora Revista dos tribunais, 2005.

. Revista Brasileira de Ciências Criminais, nº 66, maio-junho de 2007. Editora Revista dos tribunais - IBCCRIM.

FERNANDES, Antonio Scarance; MORAES, Maurício Zanoide de; ALMEIDA, José Raul Gavião de. (coords.). Crime Organizado - Aspectos Processuais. São Paulo: Editora Revista dos Tribunais, 2009.

FERNANDES, Fernando. O processo penal como instrumento de política criminal. Coimbra: Almedina, 2001.

FERRAJOLI, Luigi. Direito e Razão: Teoria do Garantismo Penal. $2{ }^{a}$ edição. São Paulo, tradução de Juarez Tavares, Revista dos Tribunais, 2006.

1997.

Diritto e Ragione: Teoria do Garantismo Penale. $4^{\mathrm{a}}$ edição. Roma/Bari: Laterza, 
FERRAZ, Tércio. Sigilo de dados: o direito à privacidade e os limites à função fiscalizadora do Estado, Revista dos Tribunais - Cadernos de Direito Tributário e Finanças Públicas, ano 1, outubro/dezembro de 1992.

FERREIRA, Aurélio Buarque de Holanda. Novo Dicionário Aurélio da Língua Portuguesa, $2^{\mathrm{a}}$ edição. Rio de Janeiro: Nova Fronteira, 1998.

FILHO, Antonio Magalhães Gomes. A motivação das Decisões Penais. São Paulo: Editora Revista dos Tribunais, 2001.

Direito à Prova no Processo Penal. São Paulo: RT, 1997.

. Notas sobre a terminologia da prova (reflexos no processo penal brasileiro) In Estudos em homenagem à Professora Ada Pellegrini Grinover. Flavio Luiz Yarshell e Maurício Zanoide de Moraes (orgs.). São Paulo: DPJ Editora, 2005.

Provas In As Reformas no Processo Penal: as novas leis de 2008 e os projetos de reforma. Maria Thereza Rocha de Assis Moura (coord.). São Paulo: Editora Revista dos Tribunais, 2008.

FILHO, Élio Wanderley de Siqueira. Repressão ao Crime Organizado: Inovações da lei 9.034/95. Curitiba: Juruá, 1995.

. Crimes Praticados por Organizações Criminosas - Inovações da Lei $n^{\circ}$ 9.034/95 $-\mathrm{RJ}, \mathrm{n}^{\mathrm{o}} 217-$ nov/95.

FILHO, Vicente Greco. A Entrega vigiada e o Tráfico de Pessoas. In Tráfico de Pessoas. Laerte Marzagão Júnior (coordenador). São Paulo: Editora Quartier Latin, 2010.

$\langle$ http://www.grecofilho.com.br/pdfs/entrega_vigiada.pdf $\rangle$. Acesso em 22.08.2010.

FILHO, Vicente Greco; RASSI, João Daniel. Lei de Drogas Anotadas. São Paulo: Saraiva, 2009.

FLORIAN, Eugenio. De las pruebas penales, tomos I e II, $3^{\mathrm{a}}$ reimpressão da $3^{\mathrm{a}}$ Santa Fé de Bogotá: Editorial Temis, 1998.

FONSECA-HERRERO, Marta Gómez de Liaño. Criminalidad Organizada y medios extraordinarios de investigación. Editorial Colex, Madrid: 2004.

FRANCO, Alberto Silva. Um difícil processo de Tipificação, Boletim IBCCRIM, $\mathrm{n}^{\circ}$ 21. São Paulo: 1995. 
FRANCO, Alberto Silva; NINNO, Jefferson; JÚNIOR, José Silva. Leis Penais Especiais e sua Interpretação Jurisprudencial. $7^{\text {a }}$ edição. Vol. 1. São Paulo: Revistas dos Tribunais, 2001.

FRONDIZI, Román Julio e DAUDET, María Gabriela S. Garantías y eficiência en la prueba penal. Buenos Aires: Libreria Editora Platense, 2000.

GASPAR, Antonio Henriques. Os novos desafios do processo penal no século XXI e os direitos fundamentais, um difícil equilíbrio, Revista Portuguesa de Ciências Criminais. Coimbra: Coimbra Editora, abril-junho 2005.

GOMES, Luiz Flávio. Crime organizado: o que se entende por isso depois da Lei 10.217, de 11.04.2001? Apontamentos sobre a perda da eficácia de grande parte da Lei 9.034/95. São Paulo: Revista dos Tribunais, v. 91, nº 795, jan. 2002.

Usuário de drogas: transação, descumprimento, reincidência e sentença condenatória. Edição Especial Nova Lei de Tóxicos - Informativo Jurídico CEDOC n⿳0 31/07 do Tribunal de Justiça do Estado do Paraná.

GOMES, Luiz Flávio; CERVINI, Raúl. Crime Organizado: enfoques criminológico, jurídico (Lei 9.034/95) e político criminal. $2^{a}$ edição. São Paulo: Editora Revista dos Tribunais, 1997.

GOMES, Rodrigo Carneiro e SANTOS, Getúlio Bezerra. Ação controlada é eficaz contra o crime organizado. (Texto apresentado no painel "Entregas Controladas", no Seminário Executivo Sul-Americano de Segurança Pública da IACP - International Association of Chiefs of Police, em Fortaleza). In: <http://www.conjur.com.br/2006-ago27/acao_controlada_eficaz_crime_organizado>.

GOMES, Rodrigo Carneiro. A Novíssima Lei de Entorpecentes (Lei 11.343/2006) e as Modificações da "Ação Controlada" ou "Não-Atuação Policial". Revista de Doutrina da 4 a Região, Porto Alegre, n. 16, Disponível em <http://www.revistadoutrina.trf4.jus.br/artigos/edicao016/Rodrigo_Gomes.htm>, fevereiro de 2007.

. Investigação Criminal na Convenção de Palermo: Instrumento e Limites. In Limites Constitucionais da Investigação. Rogério Sanches Cunha, Pedro Taques, Luiz Flávio Gomes (coords.). São Paulo: Editora Revista dos Tribunais, 2009.

- O Crime Organizado na Visão da Convenção de Palermo. $2^{\mathrm{a}}$ edição. Belo Horizonte: Editora Del Rey, 2009.

GONÇALVES, Fernando; VALENTE, Manuel Monteiro Guedes; ALVES, Manuel João. $O$ novo regime jurídico do agente infiltrado. Edições Almedina, 2001.

GRINOVER, Ada Pellegrini. O Crime Organizado no Sistema Italiano. Justiça Penal, $\mathrm{n}^{\circ}$ 3, RT, 1995. 
. Procedimentos sumários em matéria penal. In O processo em evolução. Rio de Janeiro: Forense, 1996.

. Interceptações Telefônicas e Gravações Clandestinas no Processo Penal. Novas Tendências do direito processual. Rio de Janeiro: Forense Universitária, 1990.

. Liberdades Públicas e Processo Penal: as interceptações telefônicas. $2^{\mathrm{a}}$ edição.

São Paulo: RT, 1982.

GRINOVER, Ada Pellegrini; FERNANDES, Antonio Scarance; FILHO, Antonio Magalhães Gomes. As Nulidades no Processo Penal, $8^{\text {a }}$ edição, São Paulo: Editora Revista dos Tribunais, 2004.

GUEIROS, Artur. Seminário promovido pela Escola Superior do Ministério Público Federal, "Cooperação Penal no Mercosul", realizado no Rio Grande do Sul, em outubro de 2001.

GUIMARÃES, Isaac Sabá. Tóxicos - Comentários, Jurisprudência e Prática, Curitiba: Juruá, 2002.

HARADA, Kiyoshi. Tratado internacional e prisão por dívida. <http://jus2.uol.com.br/doutrina/texto.asp?id=12078>. Acesso em: 03 jul. 2010.

HASSEMER, Winfried. Segurança Pública no Estado de Direito. Revista Brasileira de Ciências Criminais, no 5. São Paulo: RT, ano 2, jan-mar, 1994.

HOLGEASESOR, Kristian. La Fiscalización Internacional de Drogas y la Técnica de la Entrega Vigilada. VII Simposio Internacional de Criminalística. Policía Nacional de Colombia Versión electrónica en www.Policía.gob.co.Separata.

HUIDOBRO, Luis Fernando Rey. La entrega Vigilada de drogas: El Artículo 263 bis De La Ley de Enjuiciamiento Criminal. Revista del Ministerio Fiscal. $\mathrm{n}^{\circ}$ 2, julio- diciembre, Madrid, 1995.

HUSEK, Carlos Roberto. Curso de Direito Internacional Público. Ed. LTR, 5a edição, São Paulo, 2004.

INCHAUSTI, Fernando Gascón. Infiltración Policial y “Agente Encubierto". Granada: Comares, 2001.

JESUS, Damásio de. Entrega Vigiada. São Paulo: Complexo Jurídico Damásio de Jesus, fev. 2002. Disponível em: 〈www.damasio.com.br>.

JÚNIOR, Aury Lopes. Justiça negociada: utilitarismo processual e eficiência antigarantista. In Diálogos sobre a justiça dialogal: teses e antíteses sobre os processos de informalização e privatização da justiça penal. Salo de Carvalho e Alexandre Wunderlich (Coords.). Rio de Janeiro: Lumen Juris, 2002. 
JÚNIOR, Humberto Theodoro. Curso de Direito Processual Civil. Vol. I, 47ª edição. Rio de Janeiro: Editora forense, 2007.

JÚNIOR, Miguel Reale. Crime Organizado e Crime Econômico. Revista Brasileira de Ciências Criminais, São Paulo: RT, v. 4, nº 13, jan-mar, 1996.

JUNIOR, Nelson Nery e NERY, Rosa Maria de Andrade. Código de Processo Civil Comentado. $6^{\mathrm{a}}$ edição. São Paulo: Editora Revista dos Tribunais, 2002.

KELSEN, Hans. Théorie Du droit international public. Recueil des Cours de L'Academie de Droit International de La Haye, Vol. III, 1953.

LARONGA, Antonio. Le Prove Atipiche nel Proceso Penal. Editora CEDAM, 2002.

MAGLIE, C. de: L'agente provocatore. Edersa Editoriales: Madrid, 2004.

MAIA, Rodolfo Tigre. O Estado desorganizado contra o crime organizado, Anotação à Lei Federal 9.034/95. Lumen Juris, 1997.

MAIEROVITCH, Walter Fanganiello As Associações Criminosas Transnacionais. In Justiça Penal: críticas e sugestões, v. 3. Jaques Camargo Penteado (Coord.). São Paulo: Editora Revista dos Tribunais, 1995.

MARTÍN, Joaquín Delgado. La Criminalidad Organizada. Barcelona: J. M. Bosch Editor, 2001.

MELLO, Celso D. de Albuquerque. Direito Internacional Público: Tratados e Convenções. $5^{\mathrm{a}}$ edição. Renovar, 1997.

MENDRONI, Marcelo Batlouni. Crime Organizado: Aspectos Gerais e Mecanismos Legais. $2^{\mathrm{a}}$ Edição. São Paulo: Editora Atlas, 2007.

MINGARDI, Guaracy. O Estado e o Crime Organizado. São Paulo: IBCCRIM, 1998.

MOLINA, García Pablos de. Criminologia. São Paulo; RT, 1992.

MONT, Fernando Gómes. La Procuración de Justicia: Problemas Retos y Perspectivas. Legislación Vigente y Poder de la Delincuencia Organizada: Necesidad de Reformas. México: Editorial Amanuense, 1994.

MONTOYA, Mario Daniel. Informantes y Técnicas de Investigación Encubiertas. $2^{\mathrm{a}}$ edição. Buenos Aires: Ad Hoc, 2001. . Máfia e Crime Organizado. Rio de Janeiro: Editora Lumen Juris, 2007. 
MOUSO, Paulo. Cooperación judicial inter-etática. Revista Colombiana de Derecho Processal, ano III, vol. 2, Bogotá, 1990.

NAHUM, Marco Antonio Rodrigues. A Repressão ao Crime, e o Antiterrorismo, Boletim IBCCRIM - ano 11, n. 128, julho, 2003.

NEISTEIN, Mariângela Lopes. O agente infiltrado como meio de investigação. Dissertação de Mestrado da Universidade de São Paulo: 2006.

NOGUEIRA, Carlos Frederico Coelho. A lei da "caixa preta". In Justiça Penal: Críticas e Sugestões, v. 3. Jaques de Camargo Penteado (coord.). São Paulo: RT, 1995.

NOGUEIRA, Carlos Frederico. A lei da caixa preta. Revista Justitia, v. 172, 1995.

NUCCI, Guilherme de Souza. Leis Penais e Processuais Penais Comentadas. São Paulo: Revista dos Tribunais. 2006.

PAIVA, Mario Antônio Lobato de. Debate ocorrido no "Congresso Internacional de Direito e Tecnologias da Informação”. Revista CEJ- Centro de Estudos Judiciários, número 19, dezembro de 2002.

PELlEGRINI, Angiolo; JÚNIOR, Paulo José da Costa. Criminalidade Organizada. São Paulo: Editora Atlas, 2a edição, 2008.

PENTEADO, Jacques de Camargo. Duplo grau de jurisdição no processo penal: garantismo e efetividade. São Paulo: Revista dos Tribunais, 2006.

PEREIRA, Flávio Cardoso. A Moderna Investigação Criminal. In Limites Constitucionais da Investigação. Rogério Sanches Cunha, Pedro Taques, Luiz Flávio Gomes (coords.). São Paulo: Editora Revista dos Tribunais, 2009.

. Meios extraordinários de investigação criminal. Infiltrações policiais e entregas vigiadas (controladas). In: <http://jus2.uol.com.br/doutrina/texto.asp?id=11258>. Acesso em 15.04.2010.

PINTO, Luciana Ferreira L.; BICUDO, Tatiana. A lei contra o crime organizado exige debate mais sério, por toda a sociedade. Boletim IBCCRIM, nº 12, p.1, jan. 1994.

PRADEL, Jean. Trafic de drogue. Droit pénal compare. $3^{\mathrm{a}}$ edição. Paris: Dalloz, 2008.

Procédure pénale. 10. ed. Paris: Cujas, 2000.

PROST, K.. D. C. Jayasuriya, R. K. Nayak, A. Wells (eds.). Breaking Down the Barriers: International Cooperation in Combating Transnational Crime, Global Drugs Law. Har-Anand Publications PVT, Ltd, New Delhi, Pakistan, 1997. 
RABELO, Carolina Gladyer. A cooperação jurídica internacional e o crime organizado transnacional. Prisma jurídico, São Paulo, v. 6. Central de Informações sobre Cooperação Jurídica Internacional, Brasília, DF. Disponível em: http://www.cnj.jus.br/handle/26501/1627. Acesso em 2 junho de 2010.

RASCOVSKI, Luiz; NEISTEIN, Mariângela Lopes. Alguns Aspectos Referentes à Entrega Vigiada no Direito Brasileiro. Informativo Eletrônico do Instituto Brasileiro de Ciências Criminais - IBCCRIM, julho de 2007.

REZEK, J.F.. Direito Internacional Público: Curso Elementar. 10ª edição. Saraiva, 2007.

RINALDI, Stanislao. Criminalidade Organizada de Tipo Mafioso e Poder Político na Itália. Revista Brasileira de Ciências Criminais, São Paulo: RT, v6, nº 22, abr-jun, 1998.

RIPOLLÉS, Díez. Los delitos relativos a drogas tóxicas, estupefacientes y substancias psicotrópicas, Madrid, 1989.

RIVAS, Nicolás García. Criminalidade Organizada y Tráfico de Drogas. Revista Penal no 2 , editorial Praxis em colaboración com lãs Universidades de Huelva, Salamanca Y Castilla - La Mancha, Julio 1998.

RODRÍGUEZ, Vidales. La última reforma de Codigo Penal em material de tráfico de drogas en revista General del derecho, año XLIX, nº 583, abril 1993.

SALDARRIAGA, Victor Roberto Prado. La Entrega Vigilada: orígenes y desarrollos. In <http://www.unifr.ch/ddp1/derechopenal/articulos/a_20080526_66.pdf〉.

SÁNCHEZ, Jesús María Silva. La Expansión del Derecho Penal. Aspectos de La Política Criminal en las Sociedades Postindrustriales. Cuadernos Civitas, Paracuellos del Jarama (Madrid), 1999.

- Bases de una dogmática jurídico-penal supranacional. Revista Brasileira de Ciências Criminais, São Paulo: RT, v. 3, n.12, out-dez, 1995.

SÁNCHEZ, Juan Muñoz. La moderna problemática jurídico penal del agente provocador. Espanha: Tirant lo Blanch, 1995.

SÁNCHEZ, Maria Isabel García de Paz. La criminalidad organizada: aspectos penales, procesales, administrativos y policiales. Madrid: Dykinson, 2005.

SANCTIS, Fausto Martin de. Crime Organizado e Lavagem de dinheiro: destinação de bens apreendidos, delação premiada e responsabilidade social. São Paulo: Editora Saraiva, 2009.

SANTAMARÍA, Claudia Moscato. El agente encubierto en el estado de derecho. Buenos Aires: Editora La Ley, 2000. 
SANTIN, Valter Foleto. Controle judicial da segurança pública. São Paulo: Editora Revista dos Tribunais, 2004.

SANTOS, José Roberto Bedaque dos. Poderes Instrutórios do Juiz. $2^{\mathrm{a}}$ edição. São Paulo: Editora Revista dos Tribunais, 1996.

SANTOS, Moacyr Amaral. Primeiras Linhas de Direito Processual Civil, $13^{\text {a }}$ Ed., vol. II, São Paulo: Saraiva, 1994.

SFERLAZZA, Ottavio. Processo Acusatorio oral y delincuencia organizada. México: Fontamara, 2006.

SILVA, de Plácido e. Vocabulário Jurídico. 12a edição, vol. II. Rio de Janeiro: Forense, 1996.

SILVA, Eduardo Araujo da. Crime Organizado: Procedimento Probatório. $2^{\text {a }}$ edição. São Paulo: Editora Atlas, 2009.

SILVA, Luis Virgilio Afonso da. O Proporcional e o Razoável. São Paulo: Editora Revista dos Tribunais, RT 798.

Direitos Fundamentais, São Paulo: Editora Melhoramentos, 2009.

SIRACUSANO, Delfine; GALATI, A; TRANCHINA, G.; ZAPPALÀ, E. Diritto Processuale Penale. Vol. I, $3^{\text {a }}$ Ed. Milano: Giuffré Editore, 2001.

SIRACUSANO, Delfine. Prova - Nel nuovo Codice di Procedura Penale. Enciclopedia Giuridica Treccani, Roma, 1991. vol. XXV.

Diritto processuale penale, vol. I, Milano, Giuffrè, 1994.

SOBRINHO, Mário Sérgio. O Crime Organizado no Brasil. In Crime Organizado - Aspectos Processuais. Antonio Scarance Fernandes; Maurício Zanoide de Moraes; José Raul Gavião de Almeida. (coords.). São Paulo: Editora Revista dos Tribunais, 2009.

SOUZA, Sérgio Ricardo de. A Nova Lei Antidrogas. Rio de Janeiro: Editora Impetus, 2007.

STEINER, Sylvia Helena de Figueiredo. A Convenção Americana Sobre Direitos Humanos e sua Integração ao Processo Penal Brasileiro. Editora Revista dos Tribunais. São Paulo, 2000.

TARUFFO, Michele. La prova dei Fatti Giuridici - Nozioni Generali. Milano: Dott. A. Giuffrè Editore, 1992.

TOLEDO, Francisco de Assis. A modernização das leis penais. In Justiça Penal: críticas e sugestões, vol. 3. Jaques de Camargo Penteado (coord.). São Paulo: RT, 1995. 
TONINI, Paolo. A Prova no Processo Penal Italiano (trad. Alexandra Martins Daniela Mróz). São Paulo: Revista dos Tribunais, 2002.

TORRES, Jaime Vegas. Detención y apertura de paquetes postales: especial consideración de la apertura de paquetes en el marco de las entregas vigiladas. Tribunales de justicia: Revista española de derecho procesal, 1997.

TRIEPEL, H.. Les rapports entre Le droit interne ET Le droit international. Recueil des Cours de L'Academie de Droit International de La Haye, Vol. I, 1923.

TROTTA, Sandro Brescovit. As Jurisdições Penais Supranacionais e os Instrumentos de Proteção aos Direitos humanos. Dissertação de Mestrado, PUC Rio Grande do Sul, 2006.

UBERTIS, Giulio. Il contradittorio nella formazione della prova penale. In Estudos em homenagem à Professora Ada Pellegrini Grinover. Flavio Luiz Yarshell e Maurício Zanoide de Moraes (orgs.). São Paulo: DPJ, 2005.

VADELL, Lorenzo M. Bujosa. La prueba testimonial ante la delincuencia organizada. México: Porrua, 2006.

VAGGIONE, Luiz Fernando e SILVEIRA, Rodrigo Mansour Magalhães da. $O$ Crime Organizado na Itália e as medidas adotadas para o seu combate In Crime Organizado Aspectos Processuais. Antonio Scarance Fernandes; Maurício Zanoide de Moraes; José Raul Gavião de Almeida. (coords.). São Paulo: Editora Revista dos Tribunais, 2009.

VELASCO, M. Díez de. Instituciones de derecho internacional público. $8^{\mathrm{a}}$ edição. Madrid: Tecnos, 1988.

WEIS, Carlos. Direitos Humanos Contemporâneos. São Paulo: Malheiros, 1999.

WUNDERLICH Alexandre. Sociedade de consumo e globalização: abordando a teoria garantista na barbárie. (Re)afirmação dos direitos humanos. In Diálogos sobre a justiça dialogal: teses e antíteses sobre os processos de informalização e privatização da justiça penal. Salo de Carvalho e Alexandre Wunderlich (Coords.). Rio de Janeiro: Lumen Juris, 2002.

YACOBUCCI, Guillermo J.. El Crimen Organizado. Editorial Ábaco de Rodolfo Depalma, Buenos Aires, 2000.

ZAFFARONI, Eugenio Raúl - nada personal: ensayos sobre crimen organizado y sistema de justicia, in jornadas sobre criminalidad organizada y sistema de justicia penal (2000). Universidad Nacional de Buenos Aires, Ediciones Depalma, 2001.

- “Crime Organizado”: uma categorização frustrada. Discursos Sediciosos, Rio de Janeiro: Relume/Dumará, ano I, vol. 1, 1996. 
Politica criminal em matéria de drogas em la República Argentina, em La Actual política criminal sobre drogas. Uma perspectiva comparada (coord. Díez Ripollés Y Laurenzo Copello), Valencia, 1993.

ZIEGLER, Jean. Os Senhores do Crime: novas máfias contra a democracia. Tradução de Manuela Torres. Lisboa: Terramar, 1999.

ZILLI, Marcos Alexandre Coelho Zilli. A Iniciativa Instrutória do Juiz no Processo Penal. São Paulo: Editora Revista dos Tribunais, 2003. 